\title{
How Have Descriptions of the Arab-Israeli Conflict Changed in High School U.S. History Textbooks Since the 1950s?
}

\author{
Andrea Smith \\ Cedarville University
}

Follow this and additional works at: http://digitalcommons.cedarville.edu/education theses

Part of the Education Commons, and the History Commons

\section{Recommended Citation}

Smith, Andrea, "How Have Descriptions of the Arab-Israeli Conflict Changed in High School U.S. History Textbooks Since the 1950s?" (2011). Master of Education Research Theses. 36.

http://digitalcommons.cedarville.edu/education_theses/36 


\title{
HOW HAVE DESCRIPTIONS OF THE ARAB-ISRAELI CONFLICT CHANGED IN
} HIGH SCHOOL U.S. HISTORY TEXTBOOKS SINCE THE 1950s?

\author{
A research proposal submitted in partial fulfillment \\ of the requirements for the degree of \\ Masters of Education
}

By

ANDREA L. SMITH

B.A. Integrated Social Studies Education, Cedarville University, 2004

2011

Cedarville University 


\section{CEDARVILLE UNIVERSITY \\ SCHOOL OF GRADUATE STUDIES}

August 9, 2011

I HEREBY RECOMMEND THAT THE THESIS PREPARED UNDER MY

SUPERVISION BY Andrea Smith ENTITLED How Have Descriptions of the Arab-Israel

Conflict Changed in High School U.S. History Textbooks Since the 1950s? BE ACCEPTED

IN PARTIAL FULFILLMENT OF THE REQUIREMENTS FOR THE DEGREE OF Master

of Education.

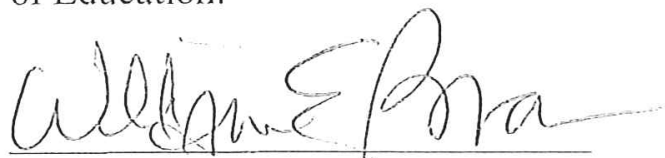

William E. Brown, Ph, D.

President

Stephen S. Gruber, Ed. D.

Education Department Chair

Coordinator, M. Ed. Program

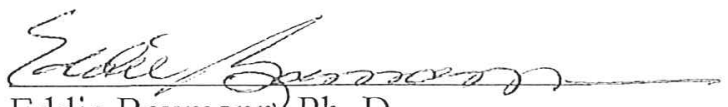

Eddie Baumann, Ph. D.

Professor of Education

Thesis Advisor
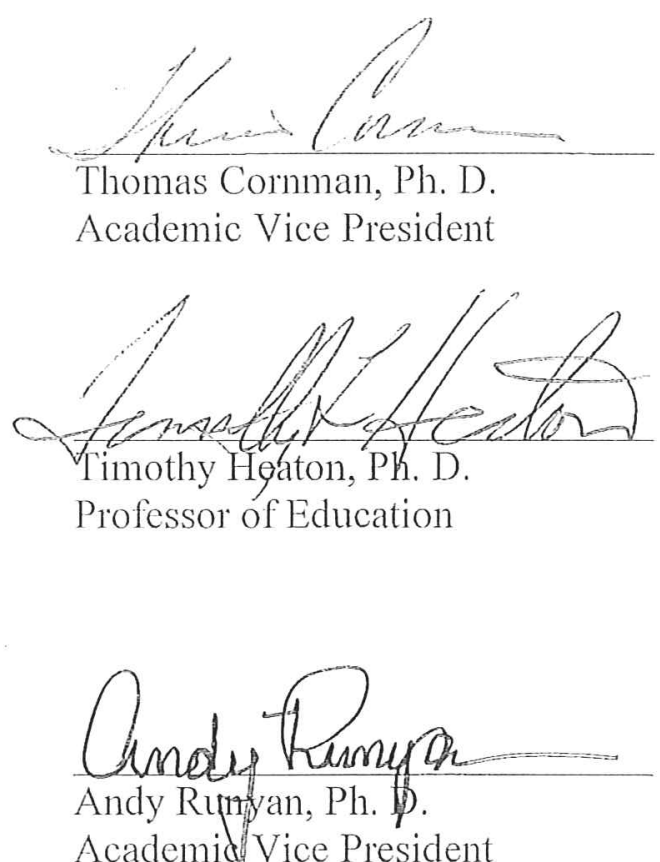

Academid Vice President 


\begin{abstract}
Smith, Andrea. M.Ed., Education Department, Cedarville University, 2011. How Have Descriptions of the Arab-Israel Conflict Changed in High School U.S. History Textbooks Since the 1950s?
\end{abstract}

This study is a qualitative and quantitative analysis of textbook content regarding the Arab-Israeli conflict, among three of the top textbook publishers in the United States from the 1950s to the present. The goal of this study was to highlight whether there has been more or less emphasis on particular events over time, and identify major patterns and changes in textbook content on the Arab-Israeli conflict. This thesis also addresses some of the historic, political, social, and educational implications of those changes. The conclusions and recommendations portion of the research contains suggestions for overcoming the limitations of textbook portrayals of the Arab-Israeli conflict. 


\section{TABLE OF CONTENTS}

I. INTRODUCTION ................................................

Definition of Terms.................................... $7-10$

Statement of Issue......................................10-11

Scope of the Study and Delimitations........................11-14

Significance of the Study................................14-16

Methods of Procedure....................................17-23

II. LITERATURE REVIEW .............................................

Comprehensive Content Analyses.........................24-26

General Textbook Reviews..............................26-32

Textbook Reviews on the Middle East/Arab-Israeli Conflict..32-40

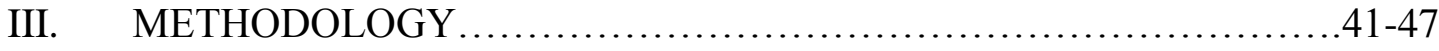

Rationale.................................................41-45

Arab-Israeli Historiography.............................45-47

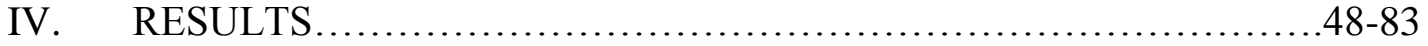

1948 War..................................................... $48-51$

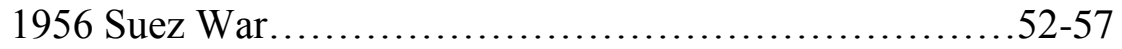

1967 Six Day War.......................................57-61

1973 Yom Kippur War.................................61-65

1979 Camp David......................................65-70

1980s/Lebanon...........................................70-73

1990s Peace Negotiations..................................74-77 


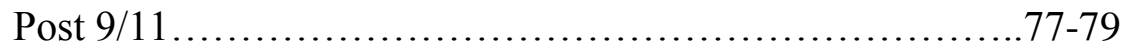

Overall Summary of Research Findings..................79-83

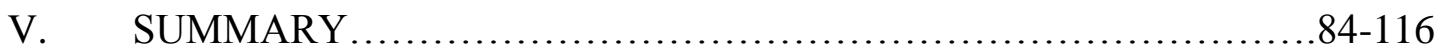

The Historic Progression of History Education, the Social Studies, and Textbooks ....................................... $84-85$

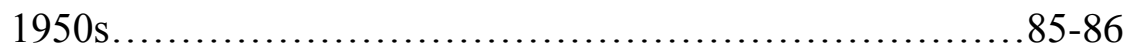

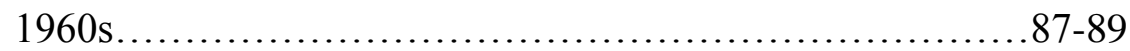

1970 s................................................... $90-91$

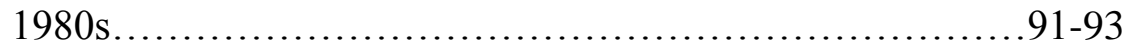

1990s.............................................93-97

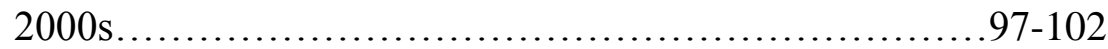

History of the Textbook Publishing

Industry and Process...............................102-106

Textbook Publishing Industry and Process

Conclusion.......................................106-107

Patterns in the Textbooks Regarding the Arab-Israeli

Conflict...........................................107-109

Conclusions and Recommendations....................109-116

VI. References..................................................117-136

VII. Appendix A............................................137-146

VIII. Appendix B................................................147-261

1948 War......................................147-167

1956 Suez War..................................167-193 
1967 Six Day War..................................193-204

1973 Yom Kippur War............................204-223

1979 Camp David.................................224-240

1980s/Lebanon...................................240-249

1990s Peace Negotiations............................249-258

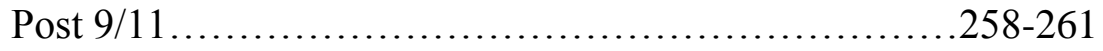

IX. Appendix C........................................................ 


\section{ACKNOWLEDGEMENTS}

Every good and perfect gift is from above (James 1:17), and so I would like to thank my Lord and Savior, Jesus Christ for giving me the opportunity and ability to pursue a Master's degree in education.

Also deserving thanks is my husband, Denver Smith, for his talents with Microsoft Excel, and for his encouragement and understanding throughout this process. Thanks also to my mom, Becky Howell, and my mother-in-law, Patty Smith, for their willingness to take on babysitting duties so that I could work - this thesis would never have gotten finished without you! And to my dear sister, Jen Berning-I never would have started this whole process in the first place, were it not for your company that first

summer. A thanks also goes to my two-year-old inspiration to finish, Lincoln Smith. What a blessing my family is to me!

Many times, I had to rely on the skills and perseverance of librarians who helped me track down copies of long forgotten textbooks and other hard to find sources and materials, and so I am indebted to:

Luann Nicholas (Cedarville University, Cedarville, Ohio) Lynne Funtik (Cedarville University, Cedarville, Ohio) Rose Ann Kerns (Amos Memorial Public Library, Sidney, Ohio) Alice Burger (Edison State Community College, Piqua, Ohio) Elsa Barber (Edison State Community College, Piqua, Ohio)

I am also indebted to Pastor James Alter, at Grace Baptist Church in Sidney, Ohio, for allowing me access to his personal library of books, and whose message series "Shaken" largely inspired the topic of this thesis. 
Lastly, thanks to my editor and friend, Rachel Shaver for working her magic on my grammar and punctuation, and to my advisor, Dr. Eddie Baumann, whose input was always so timely, thoughtful, and helpful. 


\section{INTRODUCTION}

On September 23, 2009, America's foreign policy regarding the Arab-Israeli conflict took a subtle, yet significant turn. In a speech to the United Nations, President Barack Obama stated: "We continue to call on Palestinians to end incitement against Israel, and we continue to emphasize that America does not accept the legitimacy of continued Israeli settlements." President Obama also said that of the four issues that separate the two sides (security, borders, refugees, and Jerusalem), the goal was clear: a secure, Jewish state for Israel and "a viable, independent Palestinian state with contiguous territory that ends the occupation that began in 1967" (Obama, 2009). In a television interview after the speech, the former U.S. ambassador to the United Nations John Bolton later summarized the subtlety and significance of this statement:

Well, I think this is one of the indications why Israel should be very worried about the tone of the speech. He didn't say, no new settlements. He said, 'the legitimacy of continued Israeli settlements,' which to me calls into question everything that's been built in the territories occupied since 1967. That was only one of the things he said, but it was very striking

(Bolton, 2009).

The effect of one word to inflame or calm this historic struggle between Israel and the Arab world and the significant change in foreign policy toward Israel on the part of the U.S. led to the research question, how have descriptions of the Arab-Israeli conflict changed in high school U.S. history textbooks since the 1950s? In his review of history textbooks for the American Textbook Council, Sewall demonstrates the importance of this research question:

In covering the Middle East since World War II, history textbooks cannot ignore Israel. Its past and future are intertwined regionally with Islam, a religion with elements that are resolutely hostile to its existence and 
people. Religious tensions in the Middle East since the creation of Israel in 1947 are unresolved. They are at the center of the most significant and intractable geopolitical confrontation in the world today. Editors try to be evenhanded, with mixed results" (emphasis added) (Sewall, 2004).

A similar investigation of Israeli textbooks by Podeh cited a study in which Israeli students showed a gradual increase in the "articulation of negative Jewish attitudes toward the Arabs since the 1970s" (Podeh, 2000). Although there may be many reasons for this shift, Podeh suggests the main reason was "biased textbooks [that] constitute an important factor in the adoption of negative attitudes toward the Arabs." Similar to the U.S., he also states that since "personal Jewish-Arab encounters have been a rare phenomenon, school textbooks have become a key medium for acquaintance with the ‘other”" (Podeh, 2000). For U.S. history textbooks, however, it becomes a medium for acquaintance with and forming impressions of both sides of the conflict. Conceivably then, these impressions that are internalized in school and later expressed as an adult become the foundation for understanding and responding to this conflict, especially politically. Podeh encapsulates this need for examining textbook portrayals of the ArabIsraeli conflict: "Since human behavior is largely shaped not only by reality but by the perception of it, it is highly likely that perceptions (whether genuine or false) of this conflict affect the future course of events" (Podeh, 2000). Several studies cited in Avery's article Exploring Political Tolerance with Adolescents found that "similar to adults, the more negatively adolescents perceive a group, the less likely they are to extend rights to the group" (Avery, Bird, Johnstone, Sullivan, \& Thaihammer, 1992).

Interestingly, a 2000 study investigating the depiction of Arabs and Muslims in American news media from 1956 to 1997 found that "the editorials of major U.S. newspapers, the New York Times, Chicago Tribune, and Los Angeles Times, have consistently depicted 
Europeans and Israelis in favorable light, while showing anti-Arab and anti-Muslim biases" (Young \& Sharifzadeh, 2003).

Before looking at the role of textbooks in U.S. history classrooms, it seems appropriate to examine the importance that the U.S. places on history education in general. Ross and Marker describe social studies, along with its educators, in terms of polar purposes - from "indoctrination" or a "citizenship transmission" model of social studies education to "critical thought" or "informed social criticism" social studies education (Ross \& Marker, 2005). The former relies on the belief that certain information is essential for good citizenship, the information is generally constant over time, and it is agreed upon by a consensus of experts in the field. The latter believes that the purpose of social studies is to provide students with opportunities for critical examination and even revision of "past traditions, existing social practices, and modes of problem solving” (Ross \& Marker, 2005). History and social studies curriculum throughout the decades in the U.S. can be seen as a swinging pendulum between these two polarities, but often, U.S. history is considered "the subject through which the political, social, and economic heritage of the nation is transmitted and, together with Civics, is considered essential preparation for citizenship" (Woodward, 1982). Another oft-stated goal for history education is to "cultivate a sense of national identity, heritage, and common values" (Lin, Zhao, Ogawa, Hoge, \& Kim, 2009). Using the history curriculum to promote patriotism and national unity is a way of life in most modern countries (G. B. Nash, C. Crabtree, \& R.E. Dunn, 1998). The way in which these goals are interpreted through the curriculum of the public schools will ultimately affect not only students' knowledge, but also their perceptions of the U.S.. Most content analysis 
studies of history textbooks have the models of "critical thought" or "informed social criticism" as their basis and believe this is the ultimate purpose of social studies education (social reconstruction rather than reproduction); however, this study will primarily investigate patterns and changes over time to the depiction of the Arab-Israeli conflict in the textbooks, and secondarily investigate how reflective textbooks have been of the major social and educational patterns and changes over time, through the lens of the Arab-Israeli conflict.

During a recent conversation with a woman who attended high school in the U.S. during the 1960s, the woman stated that she could not resist buying a copy of her U.S. history textbook because she wanted a record of history "the way it really happened." What this woman, many educators, and almost certainly all students fail to understand is the simple fact that it is impossible for authors, editors, and publishers to write, create, and produce a strictly neutral, unbiased account of anything (see discussion in Holt, 1990). Textbooks represent not just pedagogical power, but also symbolic power. They are the results of "political, economic, and cultural activities, battles, and compromises" (Apple \& Christian-Smith, 1991). Indeed, because history "contains few technical terms, scientific concepts, or formulas," readers feel more familiar with the subject and may readily accept information from the textbook with less critical examination that in other subject areas (Metcalf, 1963). Textbooks have been such a hallmark in U.S. schools that Fitzgerald, in her book, America Revised, stated: "A heavy reliance on textbooks was the distinguishing mark of American education; it was called ‘the American system' by Europeans. The texts were substitutes for well-trained teachers" (Fitzgerald, 1979). 
In the past three decades, the word "textbook" has come to inspire many different connotations, most of which are negative. With the publication of the National History Standards in 1994 and the resulting scrutiny that textbooks faced, the connotations transformed into accusations of bias, presentism, political correctness, and exceedingly multi-cultural and politicized views (G. B. Nash, 1997). The "culture wars" over textbook content resulted in studies about the use of pictures (David, 2000), the depiction of Native Americans (Sanchez, 2007), the treatment of Japanese Americans (Ogawa, 2004), portrayals of Martin Luther King, Jr. (Alridge, 2006), depictions of war and peace (Montgomery, 2006), the treatment of ethnic groups in general, (Foster, 1999a) and many more. A comprehensive study by Ravitch (2004) on 6 widely-used American history textbooks gave overall failing scores to 3 of 6 books, with the highest rated textbook receiving only a 78 percent on the 12-point criteria Ravitch used to rate each book. Yet, textbooks continue to be the predominant source of information about U.S. history used in classrooms (Harison, 2002). They so dominate classroom instruction it has been estimated that 80 to 90 percent of content knowledge available to a student comes from a textbook (Siler, 1990). Furthermore, mergers and buyouts of independent publishing companies have created a multinational, largely-consolidated textbook market. The following statistics are reflective of this trend:

In 1960, over 100 companies produced the vision of society and history taught in U.S. schools. In 1995, almost 90\% of high-school textbook production was subsumed under just seven major media companies, each owned by larger corporations. In 1995, the 'el-hi' (elementary to high school) market generated almost $\$ 2$ billion in sales. These textbooks comprised 30\% of the entire market for books in the U.S. (Perlmutter, 1997). 
While it is routinely lamented that history teachers do not know enough about their own subject - only 31percent of middle school and 41 percent of high school history teachers majored in history as an undergraduate, and an even smaller percentage teach in their specialty field (Stotsky, 2004) — it is also readily apparent that even well-prepared teachers cannot be expected to know everything required to teach a course in U.S. and/or world history. As a result, textbooks provide structure for content and teaching. It is also why the use of textbooks is so widely accepted as the norm in education (Foster, 1999a). However, it must also be recognized that textbooks represent what the books' authors and editors deem to be important, and by default contain a host of value judgments that may come to be shared by the students reading those textbooks (M. H. Romanowski, 2003a). The assumptions a textbook represents are often what inform curriculum and education policy (Issitt, 2004).

For these reasons, textbook research can be very revealing. It offers an opportunity for analysis spanning the disciplines of sociology, philosophy, and economics, as well as pedagogy. Textbooks form an empirical basis for various lines of intra- and interdisciplinary analysis (Issitt, 2004). As Appleby states in her book Telling the Truth about History:

To interrogate a text is to open up the fullness of meaning within. Everyone uses language largely unaware of the cultural specificity of words, the rules and protocols of expression, the evasions in their euphemisms, the nuances from group associations, or the verbal detours imposed by social taboos. When an astute reader points out these intriguing elements in a text, our understanding of what is being communicated, both intentionally and unintentionally, is vastly increased (Appleby, Hunt, \& Jacob, 1995).

Because of the national standards controversy of the early 1990s and the close examination of textbook content, subsequent editions from major publishers have been 
"sanitized" of any obvious markers of bias. Research must now focus on the method of presentation and what is not included rather than what is included. Instead of studying the assumptions of the textbook authors, the focus needs to be on the assumptions the authors make about the students who are going to read their textbook and the educators who are going to teach its content (Issitt, 2004).

While Ravitch (2004) argues that the system of statewide textbook purchasing should be abolished, it is unlikely this recommendation will be adopted. Few school districts can spend the time and money necessary for a thorough investigation of textbooks; as a result, textbook selection is generally determined at the state level (Tracy, 2003). For textbook publishers, the goal becomes to sell as many books as possible to a large and diverse population, with little resistance. While it makes sense to subject these textbooks to detailed analysis, the reality, as Chester Finn notes in his foreword to the Ravitch study (2004), is that there are few independent organizations willing to engage in this type of review.

\section{Definition of Terms}

Arab-Israeli conflict: This term was chosen for simplicity and clarity, even though the conflict has gone through many variations since the 1950 s and could be called by more precise names during specific points in history. Several nations have been in conflict with Israel in varying proportion since the 1950s, but most can be fairly assigned to the Arab world. This term is clear, inclusive, and can be applied throughout the decades to the present.

Bias: "Denotes a tendency in inquirers that prevents unprejudiced consideration or judgment...individual preferences, predispositions, or predilections that prevent 
neutrality and objectivity" (Schwandt, 1997). Heidegger (1889-1976) and Gadamer, as summarized in Schwandt, argue that prejudice or "prejudgment" cannot be "eliminated [or] set aside, for it is an inescapable condition of being and knowing. In fact, our understanding of ourselves and our world depend on having prejudgment. What we must do to achieve understanding is to reflect on prejudice (prejudgment) and distinguish enabling from disabling prejudice" (1997).

Content Analysis: "A generic name for a variety of means of textual analysis that involve comparing, contrasting, and categorizing a corpus of data. Contemporary forms of content analysis include...both numeric and interpretive means of analyzing data" (Schwandt, 1997).

Controversial Issue: Interpersonal conflict that is manifested in group- or individuallyheld opposing beliefs (Wilson, Haas, Laughlin, \& Sunal, 2002). However, because the public school curriculum is, according to Camicia, "embedded in the ebb and flow of the ideological struggles of society at large, the degree to which an issue in the curriculum is considered controversial also ebbs and flows" (Camicia, 2008).

Epistemology: While there are many different types of knowledge, defined generally, epistemology is the study of knowledge - its limits, structures, sources, and conditions. It is the study of the creation and distribution of knowledge in specific areas of investigation (Steup, 2005).

Grounded Theory Methodology: "This approach to the analysis of qualitative data simultaneously employs techniques of induction, deduction, and verification to develop theory. Experience with data generates insights, hypotheses, and generative questions, which are pursued through further data collection... Grounded theory methodology 
requires a concept-indicator model of analysis, which in turn employs the method of constant comparison...From this process, the analyst identifies underlying uniformities in the indicators and produces a coded category or concept" (Schwandt, 1997).

Ideology: Ideology is a collection of ideas that reflect the values of a particular group, class, or culture. This term usually has a negative connotation, connected with a distortion or obscuring of the truth.

Implicit/Hidden Curriculum: This term refers to unnamed assumptions and values of a curriculum framework as opposed to what is outlined in the course outline or objectives (Chalmers, 2003).

Intended Curriculum: This term is used to define curriculum that has been labeled as “official," “formal," “adopted,” or “explicit” (Hofman, Alpert, \& Schnell, 2007). Master Narrative: Master narratives are authoritative textbook representations of individuals or events that are discrete, one-dimensional, and/or heroic interpretations of past events (Alridge, 2006).

National History Standards: These standards are related to American and world history and attempt to determine what history students should learn. They were first issued by the National Center for History in the Schools in the fall of 1994; after being rejected by the U.S. Senate, they were revised in the spring of 1996, and remain a voluntary guide for history curriculum in the schools.

Pedagogy: Pedagogy is the act of teaching and requiring students to engage with and analyze content in order to develop higher order thinking skills (Lavere, 2008). $\underline{\text { Presentism: }}$ Most often this term refers to interpreting past events through present terms, concerns, and value systems (Shedd, 2004). 
$\underline{\text { Social History: In most cases, this term refers to the history of non-dominant groups such }}$ as women, working class, and African Americans in U.S. history (Bienstock, 1995). Textbook: While this term escapes all but the most general of definitions, it is a book of focused educational content that is coupled with some kind of curriculum framework for the purpose of learning and teaching (Issitt, 2004).

The New Left: A movement that grew out of 1960s radicalism and rejected a nationalist view of American history, the New Left embraced a new social history approach (Schulman, 1999).

The Political Right: In relation to history content and standards, this term often refers to individuals who believe that history is a collective body of universally-accepted truth and taught for the purpose of instilling patriotism and unity in young people (Foster, 1998). Traditional Curriculum: This often refers to the teaching of American history using a textbook and lecture format with a narrative, chronological approach (Yarema, 2002).

\section{Statement of Issue}

In 2001, a survey conducted by the National Assessment of Educational Progress found that 44 percent of twelfth-grade teachers reported their students read from a textbook every day, while 38 percent said their students read from textbooks once or twice a week (Ravitch, 2004). The importance of the textbook in U.S. history classrooms, whether positive or negative, cannot be denied. The issue is not limited to what topics are included in textbooks, but also includes the representations of what is included and the impressions those representations make on students. Factual knowledge may be lost after graduation, but impressions remain (M. H. Romanowski, 2003b). 
While many studies and articles written in the late 1990s pertained to history standards and textbook content, most articles written since that time provide only a general overview of textbook content quality or a very narrow focus on a specific topic. With publishers' aims to sell as many books as possible and new editions of widelyadopted textbooks being printed, the need for continued analysis of textbook content is

clear. By analyzing textbook content, the knowledge of historical errors at worst and the limitations of textbooks in the classroom at best, may make the need for teacher training and content area knowledge more apparent and reduce classroom dependence on textbooks (Tracy, 2003).

Scope of the Study and Delimitations

A common misconception when analyzing texts and interpreting the results is assuming that all readers are uncritical consumers of information. This study will not equate the text with the reader (Porat, 2006) or assume that what is in the textbook is what is taught or actually internalized by the student (Foster, 1999b). It is important to acknowledge that textbooks are never "unmediated," but are rather subject to a variety of instructional practices and decisions (M. H. Romanowski, 1995). This study, as Larsen states, will examine "textbooks as written and not as read by a student or enhanced by a teacher" (Larsen, 1991). This study is designed to examine the intended curriculum in regard to each textbook's representation of the Arab-Israeli conflict and peace processes from the Balfour Declaration to now and to present the findings in an organized and logical manner. Through this process, suggestions for how teachers may enhance the textbook's presentation or overcome its limitations follow, where appropriate. This study is not designed to be used as an evaluation tool for specific textbooks. The evaluation 
criteria and categories of analysis are not meant to outline how the conflict should be taught; the goal of this study is to highlight whether there has been more or less emphasis on particular events over time, and identify major patterns and changes to the Arab-Israeli conflict, and the political, social, and educational implications of those changes. Kliebard summarized this approach in saying:

History of the curriculum, in other words, is critically concerned with what is taken to be knowledge in certain times and places rather than what is ultimately true or valid. In particular, it considers the factors that make certain forms of knowledge eligible for inclusion in the course of study in educational institutions as well as, in some cases, why other forms of knowledge are excluded (Kliebard, 1991).

The recommendations and conclusions portion of the research contains suggestions for overcoming the limitations of textbook portrayals of the Arab-Israeli conflict. The categories of analysis were largely determined by what is included in the textbooks themselves, not what an expert in the field thinks should be included, since even "mainstream" sources can be biased. Like Podeh's study, the textbooks were allowed to speak for themselves (Podeh, 2000). Ultimately, this study is meant to "enhance the application of textbook analysis to a specific chronological period" (Siler, 1987). However, the constant comparative method of research is dependent on the skills and sensitivities of the researcher and "is not designed to guarantee that two analysts working independently with the same data will achieve the same results" (Glaser \& Strauss, 1999). While qualitative content analysis focuses on semantic validity and is often criticized for its lack of quantitative reliability and validity measures, Krippendorf captures the qualitative aspects of even computer-based content analysis when he states: "Ultimately, all reading of texts is qualitative, even when certain characteristics of a text 
are later converted into numbers. The fact that computers process great volumes of text in a very short time does not take away from the qualitative nature of their algorithms" (Krippendorf, 2006). This study will describe the Arab-Israeli conflict as presented in high school U.S. history textbooks - comparing texts within the same period, as well as changes among texts over time. Inferences will be made about the causes of these changes, as well as the effects of these changes on students (Wade, 1993). Textbooks will be examined in the context of social forces and pressures and will involve, to some degree, Anyon's “unified field theory," which involves "the interconnections between school knowledge, school processes, contemporary society, and historical change" (Anyon, 1982). Like Podeh, the aim of this study will be to "illustrate the overall picture [of the Arab-Israeli conflict] acquired by students during their school years" (Podeh, 2000).

The study's analysis will not include a full review of each textbook and the positive and negative aspects of each; neither will it be a study of American diplomatic and military efforts in Iraq and Afghanistan or the War on Terror in general, except as it relates to the specific issues of contention and proposals of peace between Israel and Palestinians. The researcher will not be examining gender bias or ranking the overall level of engagement of the material, except as it relates to any mention of Israel and/or Palestine. Finally, this study is not aimed at contributing suggestions for peaceful resolution of the Arab-Israeli conflict; it is simply designed to trace the changing emphases over time in high school U.S. history textbook representations of the ArabIsraeli conflict from the Balfour Declaration to the present. 


\section{Significance of the Study}

Encyclopedia Britannica defines history as "the discipline that studies the chronological record of events (as affecting a nation or people), based on a critical examination of source materials and usually presenting an explanation of their causes." (emphasis added) According to Webster's Second International Dictionary, a history book is also "a systematic written account of events, particularly of those affecting a nation, institution, science, or art, usually connected with a philosophical explanation of their causes." (emphasis added) Textbooks represent a very powerful means of solidifying a specific version of history for students. Studying these textbooks can provide insight into shifts within culture and within the educational system, allowing teachers and others to critically analyze the context from which content and instruction is to take place (Foster, 1999b). Teachers can also use conflict and controversy in the curriculum to help students see that "the writing of history is a social and political construction and involves competing interpretation, value judgments, partial truths, omissions, and distortions" (Moore, 2006). Curriculum research also informs educational practice with specific facts and "ways of perceiving curricular situations, thinking about them, and acting in them" (Walker, Shippen, Alberto, Houchins, \& Cihak, 2005). Research into the history of curriculum has become a legitimate area of study because, according to Kliebard (2006), "the knowledge that becomes embodied in the curriculum of schools is a significant social and cultural artifact." The textbooks themselves are a reflection of how historians of the past have interpreted the dominant values and ideologies of their age. As Moreau wrote in his book Schoolbook Nation, changing textbooks are indicative of the "national soul searching" that goes on in attempting to 
explain the nation's past (Moreau, 2003). Historical inquiry requires that students analyze information and develop an interpretation based on the information they are presented. Students cannot do this without a complete contextual representation of people and events (Lavere, 2008). Teachers who hope to avoid conflict by having the textbook settle differences of opinion — and members of the public who want to avoid controversy by pitting only good versus evil—miss the opportunity to allow students to develop critical discussion, thinking, and reflection skills (Wilson et al., 2002). The worst-case scenario (one this study hopes to help educators avoid) would be a one-sided or incongruous view of history that reinforces stereotypes and justifies oppression (Gordy, Hogan, \& Pritchard, 2004). Fragmentation is one type of disinformation that Postman described as "misleading, misplaced, fragmented or superficial informationinformation that creates an illusion of knowing something but which in fact leads one away from knowing" (Postman, 1986). The best-case scenario would be encouraging students to question their textbooks by exposing them to multiple perspectives, which is central to good history teaching (M. H. Romanowski, 1996). If teachers and textbooks fail to do this, American students are, as James Loewen states, "left with no resources to understand, accept, or rebut historical referents used in arguments by candidates for office, sociology professors, or newspaper journalists. If knowledge is power, ignorance cannot be bliss" (Loewen, 2008). As Loewen and Postman so succinctly stated, ignorance is not a neutral void. Ignorance has important implications; it can affect "the kinds of options one is able to consider, the alternatives that one can examine, and the perspectives from which one can view a situation or problem" (M. H. Romanowski, 2009). Ignorance through omission can also result in shaping readers' understandings 
and impressions of foreign and domestic policies, legitimizing some and de-legitimizing others. The Arab-Israeli conflict has enormous contemporary relevance to politicians, educators, and students because it deals with issues of national sovereignty, international diplomacy and security, equity and social justice. If textbooks avoid these issues, they do students a disservice and render the conflict irrelevant. Even more sobering is how Sewall, in his review of world history textbooks, relates the study of curriculum to national security issues:

How citizens think about themselves, their country, and the U.S. relationship to the world depends on both knowledge and civic feeling. If students grow up ignorant of the nation's Anglo-European roots and the evolution of modern liberal democracy, as citizens they will fail to appreciate their political fortune. If students learn to consider their nation unworthy or malign, or if they embrace globalist fantasies and illusions, the ability of citizens to construct robust foreign policy will be hindered or checked. In this respect, the curriculum becomes a national security issue (Sewall, 2004).

Kenton Keith, a former diplomat with the U.S. Information Agency, said, "As difficult as it may seem, the nation's reaction to the horror of 9/11 should include a focused effort to connect with those whose mistaken image of us contributes to the threats we now face" (Keith, 2005). Part of this connection should include at least a preliminary investigation into the causes of discord in the Middle East—one of which is the Arab-Israeli conflict. Since 9/11, American education systems have begun including the study of Islam in their curriculum, which according to Moore, is "heavily influenced by the Arab-Israeli conflict, the legacy of colonialism, and American policies throughout the Islamic world" (Moore, 2006). 


\section{Methods of Procedure}

Research Question: How have descriptions of the Arab-Israeli conflict changed in high school U.S. history textbooks since the 1950s?

A qualitative content analysis research methodology will be used to answer this

question. According to Weber (1990), content analysis can be used for many purposes: to "identify the intentions and other characteristics of the communicator; [to] reflect cultural patterns of groups, institutions, or societies; [and to] describe trends in communication content." While the method of content analysis was developed in the mid-1920s to examine propaganda and began as a strictly quantitative approach, the forms and theory of content analysis have progressed to include a wide variety of techniques. Weber (1990) acknowledges this shift in stating, "There is no simple right way to do content analysis. Instead, investigators must judge what methods are most appropriate for their substantive problems. Moreover, some technical problems in content analysis have yet to be resolved or are the subject of ongoing research and debate." In conducting this examination and comparison through inductive reasoning, this study hopes to produce answers to the research question as they emerge from the text. Miles and Huberman (1994) as cited in Romanowski (2009) provide steps to guide this type of qualitative content analysis:

First, all relevant passages are read and carefully examined and notes are taken. The second step — data reduction - involves selecting, focusing, and condensing textbook content through thinking about the data that best answer the research questions. The final step - data display - involves organizing and arranging data (through a diagram, chart, or text). This process indentifies themes, patterns, connections, and omissions that help answer the research questions (2009). 
The beginning inference of this study is that changes in the amount of space devoted to the Arab-Israeli conflict in textbooks represent changes in the conflict's social, cultural, and political importance over time. Content analysis is valuable for revealing these trends and is most effective when applied to specific categories of analysis, which, in the case of this present research study, will be guided by topical questions of analysis and limited by sentences that reference the topic of analysis being studied. A topic matrix of important events, leaders, and key terms related to the Arab-Israeli conflict, which are referenced in the sentences of the main text, review questions, index, and pictures from each textbook will produce visual representations of changes within the textbooks over time. Berelson summarized the value of such a design in stating:

The classification into a single set of categories of similar samples of communication content taken at different times provides a concise description of content trends, in terms or relative frequencies of occurrence... Such trend studies provide a valuable historical perspective against which the current content of the communication media can be more fully understood" (Berelson, 1952).

This archival research thesis will focus on three major textbook publishers:

- McDougal Littell (Houghton Mifflin)

- Holt, Rinehart, Winston (Harcourt)

- Prentice Hall (Pearson)

Six of the most widely-used titles from each publisher will be examined, one from each decade since the 1950s. A period of 50 years was chosen as a sufficient amount of time for revealing to what extent representations of the Arab-Israeli conflict have changed. For a list of other studies in which these textbooks were examined, and how each study determined textbooks that were widely used, see Appendix A. The rationale for the title choices stands largely on the shoulders of these previous studies, whose researchers 
compiled statewide adoption lists and surveyed state departments of education along with the nation's largest local school districts. Compiling a list of widely-used textbooks in the present decade alone is not an easy task because publishers are extremely secretive about the volume and sales of textbooks. Textbook titles with an asterisk denote titles that are currently listed by the American Textbook Council's website as having been included "in major adoptions, that, combined, hold an estimated 80 percent of the national market in U.S. and world history, grades eight to twelve." As much as possible, consideration was also given to titles that maintained a continuity of authorship.

\section{McDougal Littell (Houghton Mifflin)}

- 1952: The Making of Modern America (Canfield and Wilder)

- 1962: The Making of Modern America (Canfield and Wilder)

- 1975: This is America's Story (Wilder, Ludlum, and Brown)

- 1986: This is America's Story (Wilder, Ludlum, and Brown)

- 1996: The Americans: A history (Winthrop, Greenblatt, and Bowes)

- *2003: The Americans (Danzer)

\section{Holt, Rinehart, Winston (Harcourt)}

- 1950: America's History (Todd and Curti)

- 1966: The Rise of the American Nation (Todd and Curti)

- 1977: The Rise of the American Nation (Todd and Curti)

- 1986: Triumph of the American Nation (Todd and Curti)

- 1995: Todd and Curti's the American Nation (Todd and Curti)

- *2003: American Nation (Boyer)

\section{Prentice Hall (Pearson)}


- 1957: The United States—the History of a Republic (Hofstadter)

- 1967: The United States—the History of a Republic (Hofstadter)

- 1976: The United States (Hofstadter)

- 1986: The American Nation (Davidson)

- 1995: America: Pathways to the Present (Cayton)

- *2005: America: Pathways to the Present (Cayton)

Because textbooks in this study are considered products of their particular time and culture, this study will endeavor to concisely reconstruct the historical context for each decade being studied before looking at the topics of analysis. The goal in doing so is to increase the clarity of connections between the text and the time of its production. This study will look at several areas of each textbook. Similar to Podeh's study, textbook content will be divided into categories of analysis with identical questions for each topic. The analysis questions are quoted directly from Larsen (1991). Following are the categories of analysis and the identical questions that will be answered for all categories, in a subjective narrative format for each textbook. (See Appendix B) Mandate Period; Balfour Declaration/1948 War; 1956 Suez Canal Crisis; 1967 Six Day War; 1973 Yom Kippur War; 1979 Camp David Accords; 1980s Conflict in Lebanon; 1991-1994 Peace Talks; Post 9/11 Conflicts:

- What are the underlying problems which have generated this discourse

- What theories provide the descriptions and explanations thought relevant?

- What relationships, causes, consequences are proposed?

- On what premises is the account based and what assumptions are made in the course of the explanation? 
- What perspectives, questions, theories are not acknowledged?

After the above questions have been answered for each topic of analysis, questions regarding the overall impressions of each text will be considered, in order to establish the numerical and pro-Israel, anti-Israel, or neutral ratings for each textbook. Unless directly quoted, the following questions are adapted from Podeh's study (2000) as well as Chambliss' (1998) characteristics of a well-designed textbook, specifically as it relates to the curriculum design.

Questions for summary of textual impressions and curriculum design:

- Categories of Analysis: How are the opposing sides, people groups, or leaders described-in terms of religion, ethnicity, specific nationality (i.e., Jordanian, Egyptian, etc.), or in the case of Palestinians, as simply part of the larger Arab nations?

- Stereotypical Content: "Is the 'other' nation, group, or individual described in positive, negative or neutral terms? Special emphasis is attached to the use of delegitimizing and dehumanizing terms (e.g., terrorists, thieves, Nazis, etc.)" (Podeh, 2000).

- Role Performance: Are the opposing sides, groups, or leaders described in a peaceful or conflicting context and/or roles?

- Intentions, Blame, Lessons to be Learned: What are the aims or intentions of the opposing sides, groups, or leaders? Whose fault is a particular conflict and who is to blame for failing to achieve peace? Are there lessons to be learned about the opposing sides when reading about particular historical events? 
- Bias by Omission and Self-Censorship: Has information necessary to understand the motivations of both sides been omitted? What kind of information has been censored, and is it done in an obvious or subtle way? Would a typical high school student be able to readily discern any distortions? What problems might either side have with the text's interpretation of a particular event?

- Bias by Proportion or Disproportion: Is there too much or too little information on specific topics?

- Elements of the Text: Does the text include topics and events that are important to experts of the Arab-Israeli conflict? Does it include those that would be considered trivial to experts?

- Linkages of the Text: Does the structure of the text provide important links between cause and effect that experts would include?

In order to clearly see what has gained more or less spatial coverage over time in the textbooks, a topic matrix including key events, leaders, and terms is included, as well as line and bar graphs derived from the completed matrix. (See Appendix C). The number of sentences within the main text, index references, review questions, and pictures in which that event or leader is discussed or pictured was counted in each textbook. The review questions at the end of each chapter typically give the reader a sense of what is deemed most important from the content, and teachers pay attention to these instructional activities. Pictures and captions within the text offer insight into the authors' attempts to aid the student in understanding chapter content. The numbers for each event or leader were totaled for each decade. Defining and examining terms as they related to the topics of analysis were of utmost importance since the political viewpoint 
of one statement can be changed entirely depending on which politically charged word is chosen - this is why quantitative methods alone were insufficient for this study.

To reiterate the importance of textbooks in the classroom (and in turn this study), a survey of thirteen thousand teachers from kindergarten through college level in the U.S. "found that they use textbooks and other printed teaching material 90-95 percent of their working time, and that students interact with textbooks more than they do with their teachers" (Gal, 1981). Ravitch artfully summarizes the strange contradiction that exists in the life of a high school student today — the contrast that exists between the carefully constructed environment of school and the powerful, ever-present stimuli of media and entertainment outside its doors. As she states:

They [students] do not know and surely do not care than an entire industry of bias reviewers has insulated them from any contact in their textbooks with anything that might disturb them...this is as wacky a combination as anyone might dream up: schools in which life has been homogenized, with all conflicts flattened out, within the context of an adolescent culture in which anything goes" (Ravitch, 2003).

Through this study, rather than suggesting to make history education ever more irrelevant, the hope is that it will shed further light on the fact that history textbooks are products of time and culture themselves and can be powerful teaching resources in the hands of wise educators. 


\section{LITERATURE REVIEW}

\section{Comprehensive Content Analyses}

Research on history textbooks prior to the 1960s is uncommon in educational literature (Siler, 1986). Two comprehensive studies on history textbooks conducted prior to the 1960s are School Histories at War (Wolworth, 1938), which compares portrayals of wars throughout American history as represented in various international textbooks, and Intergroup Relations in Teaching Materials, sponsored by the American Council on Education (1949). The 1949 study concluded that textbooks were "inadequate, inappropriate, and even damaging to intergroup relations" (Siler, 1986).

When content analysis became popular in the 1960s as applied to U.S. history textbooks, a body of research surrounding historical themes, groups, and events began to emerge (Siler, 1986). There have been a host of valuable content analyses performed on themes (war, politics, economics, labor), groups (Native Americans, African Americans, women), and events (the Holocaust, World War II, Cold War, September 11) at all grade levels, so much so that the list is too extensive to include here. However, the treatment of groups has been the greatest focus of the textbook studies, particularly the imbalanced treatment of minorities and women (Siler, 1986).

In general, the criticisms of content analysis studies performed on history textbooks fit into five categories:

\section{1.) Too dull}

These studies, among others, mourn the lifeless, bland writing of history textbooks (Cheney,1988; P. Gagnon, 1988; Graves \& Slater, 1986; Loewen, 2008; G. T. 
Sewall, 1988; Shug, Western, \& Enochs, 1997; Tyson-Bernstein, 1988). Crismore (1984) and Graves and Slater (1986) experimented with adding more descriptive narration to the text in order to improve memory retention; the results were inconclusive.

\section{2.) Inaccurate or contains unnamed sources}

These studies, among others, lament the Eurocentric, male-dominated historical accounts of textbooks (Bigelow, 1989; P. Gagnon, 1987; Joseph, 1988; Zinn, 1995).

\section{3.) Overly broad in their coverage}

These studies, among others, criticize the all-encompassing nature of history textbooks (Newmann, 1988; G. Sewall, 1988; Wiggins, 1989; Woodward, 1987). While very eye-catching, Ravitch points out that the average history textbook is around 1,000 pages and difficult to follow because of the profusion of colors and graphics (2003).

\section{4.) Difficult to read and/or understand}

These studies, among others, highlight the need for educators to utilize students' background knowledge to aid in understanding the text (Armbruster \& Anderson, 1985; Beck, McKeown, \& Gromoll, 1989).

\section{5.) Imbalanced coverage of minorities and/or women}

There is a host of studies concerning the treatment of minorities and women in U.S. history textbooks. A full listing would be too exhaustive to include here; however, prominent studies, and most often cited, include Banks, 1969; Costo \& Henry, 1970; Garcia \& Tanner, 1985; Kane, 1970; and Trecker, 1971. Sadker and Sadker found that imbalanced gender representation in textbooks can reinforce the idea that women have done nothing noteworthy enough to be included in the history texts (1994). Gordy's study also highlights the negative consequences of gender imbalance (2004). 
Many studies contain more than one of the above-mentioned criticisms. This review will focus briefly on major studies that have looked at secondary history textbooks in general and will look more thoroughly at those studies that have dealt with secondary textbooks' treatment of the Arab-Israeli conflict and the Middle East in particular.

\section{General Textbook Reviews}

While not technically a scholarly study, Fitzgerald's 1979 review of social studies texts from the 1900s to the 1970s was published in the New Yorker as a series of three articles in the spring of 1979 and created a firestorm of response, prompting researchers to do more specific and scientifically rigorous content analysis studies. In the $A H A$ Newsletter, Downey and Metcalf's review of Fitzgerald's work labeled it "the most provocative document on the pedagogy of American history to be published in the seventies" (1980). According to Ward, Fitzgerald wrote America Revised because U.S. history textbooks offered "an index to the public mind" (Ward, 1980). While Ward's (1980) review of Fitzgerald's book considers it worthy of attention for examining the connection between academic history and the broader population of the American people, Marty's (1982) assessment was unforgiving. Marty criticized many aspects of Fitzgerald's work including the lack of methodology in book selection and evaluation and lack of an index: "So faulty is America Revised that it is difficult to take Ms. Fitzgerald's legitimate criticisms seriously. But America Revised needs to be criticized as a deficient book, not only in its argumentation but in its style as well" (1982). Fitzgerald's book was also criticized for failing to suggest solutions to the many problems the author noted about textbook writing and publishing (Metcalf \& Downey, 1980). Deficient or not, 
however, almost all content analysis studies of history textbooks after 1979 mention Fitzgerald's findings; even Marty recognized the need to come to terms with Fitzgerald's book "if the history taught in junior and senior high schools is to be worth teaching and worth being learned" (1982). According to Larsen (1990), Fitzgerald "reminded readers of how the certain world of textbooks in their own childhoods had changed to an uncertain one in textbooks of their children." While Fitzgerald did not explain how she chose the books included in her review, she lamented the passage of what she perceived to be the few good, entertaining texts of the past for the dull, lifeless books of the present, written in what she labeled "textbook prose" (Fitzgerald, 1979). For the most part, however, Fitzgerald claimed that textbooks had managed to maintain a fairly consistent level of dullness since the 1930s. Summarizing Fitzgerald's research, Siler stated: "The books lacked intellectual history, failed to personalize history by using abstract institutions rather than relating history as a dynamic of human interaction, and covered the major events of American history in a whizzing chronological order that could not help but be confusing" (Siler, 1990). Fitzgerald's work represents the first step in attempting to engage the American public in considering the complexities of writing, teaching, and learning history.

In her 1979 study Ideology and United States History Textbooks, Anyon examined seventeen secondary U.S. history textbooks from the "Books Approved for Use" lists in both New York City and Newark, New Jersey. Defining ideology as "an explanation or interpretation of social reality in which, although presented as objective, is demonstrably partial in that it expresses the social priorities of certain political, economic, or other groups," Anyon concluded that dominant societal groups expressed 
and legitimized power through the school curriculum (Anyon, 1982). Camicia noted Anyon's study contributed to the realization that textbooks foster the "dominant cultural norms and [promote] nation-bound metanarratives by limiting the number of perspectives in the curriculum" (2009).

In 1986, People for the American Way released their report on fifteen eighth grade and sixteen tenth grade U.S. history textbooks entitled Looking at History: A Review of Major U.S. History Textbooks. All of the reviewed books were published in 1986 and were evaluated on eight criteria: authority, interpretation, significance, context, representativeness, perspective, engagement, and appropriateness. In the foreword to the study, the 1980s was labeled the "Decade of Educational Excellence," with textbooks at the heart of the debate. The study was prompted by concern about the overall quality of American education and to ensure protection from censorship and ideological views being imposed on American students. People for the American Way designed a series of studies to help those involved in the textbook selection process make informed decisions and to encourage publishers to improve their books by "providing constructive criticism" (Davis, 1986). The study was founded on the belief that "special interest groups have contributed to the decline of textbook quality" (1986). A panel of five reviewers was selected for a "diversity of expertise and perspective," and the texts selected for review included those submitted to the 1985 Texas State Textbook Committee and other "bestselling texts available in other states" (1986). The panel found that most of the books were "good; some were excellent. Overall, the quality had improved significantly over earlier generations of history textbooks" (1986). The panel also found that the reversal of the dumbing down of textbooks proved that publishers were responding to public 
pressure. However, not every finding in the review was positive; there were two primary concerns. First, the use of readability formulas contributed to the poor writing quality of textbooks. Secondly, coverage of religion even in the "best texts" was "spotty...[and] simply not treated as a significant element in American life" (1986). When addressing religious diversity in the textbooks, it is of particular interest to the present study that the panel found "Jews exist [in the textbooks] only as the objects of discrimination..." (1986). While there were no major recommendations included in the study, its significance rests in the reviewers' and organization's belief that quality in American education and textbooks was an attainable, realistic goal.

A 1987 report by editor Gilbert Sewall and the Education Excellence Network entitled American History Textbooks: An Assessment of Quality reviewed four "established texts in the marketplace" and focused on depth of analysis rather than a broad coverage of textbooks. A panel of twelve individuals compiled their reviews and critical statements that depended on "the critical powers, sensibilities, and interests of individuals...The validity of design then rested on the selection of reviewers with wide experience in the field." (Sewall, 1987). Each reviewer answered similar questions about each textbook regarding adequacy of examples and explanations, appropriate versus trivial details, narrative style, thematic coherence, instructional design, and review materials. Reviewers were asked to "determine what was good and what was bad about the textbooks they reviewed, to use specific examples to illustrate their opinions, and to reach some overall conclusions, first about the writing in leading American history textbooks, and second, about its impact on effective teaching and learning" (Sewall, 1987). The reviewers in this study reported several problems with the textbooks, with 
overly broad coverage and "mentioning" of material looming as the largest complaint. Joan Grady, one of the reviewers, stated: "The books are universally bland, repetitious, fact-filled, and deadly in the lack of attempts to stimulate and catch the interest of the audience" (Sewall, 1987). The study concluded with six recommendations: scale down the size of textbooks, rededicate textbooks to the text (i.e., reduce the amount of graphics and pictures), hire better textbook writers, emphasize primary sources, set minority group issues into historical context, and initiate textbook reviews by independent sources. Sewall's study received scathing criticism as being merely a political document with a complete disregard for assessment criteria and sound methodology, resulting in panelists' conclusions differing and sometimes contradicting one another (Kaltsounis, 1988). Kaltsounis, writing for Social Education, concluded: "The report appears to be another U.S. Department of Education effort to discredit social studies with its interdisciplinary nature and replace it with history" (1988). Whether or not this was Sewall's intent, his study represents an attempt to inform publishers and textbook selection committees on how to produce and select better textbooks.

Although not an academic study, Woodward, Elliot, and Nagel's 1988 annotated bibliography entitled Textbooks in School and Society is a foundational starting point for any research involving textbooks in the United States. Bibliography lists are categorized into five sections, including: "textbooks and school programs, the production and marketing of textbooks, general discussion and special topics, subject matter content coverage, and ideology and controversy" (1988).

Larsen's 1990 dissertation examined fourteen elementary, middle, and high school U.S. history textbooks and attempted to identify fragmented and ahistorical 
elements in order to "suggest the concentration of textbook influences for a given period...[and] more easily lead teachers, curriculum workers and, eventually, publishers to correction." Using a parent population of all U.S. history textbooks used in Michigan in the 1980s, Larsen obtained the sample population of widely-used textbooks from three separate surveys conducted by the Michigan Department of Education. The entireties of textbooks were examined for ahistoricism, while passages regarding four specific topics were examined for fragmentation. The overall findings of the study suggested a superficial treatment of historical events, which in Larsen's assessment leads to presentist interpretations of history. Fragmentation was ubiquitous at all textbook levels (Larsen, 1991). While Larsen does an excellent job explaining the types and root causes of ahistoricism and fragmentation in the textbooks, like Fitzgerald's book, the study proposes very few solutions to the problems that are identified.

A 1991 study by Regester compared the visual and verbal content of two 1980s textbooks to two from the 1950s. Even though textbooks from the 1980s contained thirty more years of history, were larger in size, and included more color graphics, surprisingly, the study found no significant change in content "on the average total number of people, places, events, organizations, and statistical data" (Regester, 1991).

Ravitch's 2004 study of six leading U.S. history textbooks conducted by a panel of scholars based its evaluation on "accuracy, context, organization, selection of supporting materials, lack of bias, historical logic, literary quality, use of primary sources, historical soundness, democratic ideas, interest level, and graphics" (2004). This study gave failing scores to two of the twelve textbooks; the highest score any textbook received was a seventy-eight percent, or a "C." This study incorporates both criticism 
categories of "too dull" and "too broad." Summarizing the panel's findings, Ravitch observed that textbooks "blunt the edges of events and strip from the narrative whatever is lively, adventurous, and exciting. In part, this happens because so much needs to be covered and compressed in the texts; in part, it is due to the lack of authorial voice and the abilities to express wonderment, humor, outrage, or elation" (2004). Her recommendations included abolishing the statewide system of adopting textbooks, implementing a regular review of textbooks by independent agencies, hiring better educated teachers, and offering alternative history courses for graduation credit. Ravitch's study offers an updated companion to Sewall's earlier assessments and is intended largely for publishers and textbook selection committees in another effort to encourage quality in the production and selection of textbooks. Textbook reviews dealing with the Middle East or Arab-Israeli conflict

A 1961 study by Lloyd Marcus examined forty-eight textbooks used in the 1950s for their treatment of Jews and other minorities. Marcus concluded that textbook treatment of the minority groups was uneven, although gains had been made since 1949 (Marcus, 1961). Siler criticizes Marcus' study for failing to use a systematic methodology for choosing textual excerpts and failing to cite sources for textual quotes and references used in the study. Essentially discounting Marcus' attempt at a useful research guide, Siler stated: “The final evaluations and conclusions [of Marcus' study] were based upon the author's impressions of the textbooks as compared to the seven stated criteria" (Siler, 1986).

An early study on the image of the Middle East in world history textbooks by Griswold (1975) found that "the majority of textbooks erred in content, perpetuated 
stereotypes in political and social description, oversimplified complicated issues, listed outcomes while ignoring causes, and often provided moral judgments on the actions of nations in the guise of factual history" (1975). Griswold also took issue with the preferential tone of the writing, which favored Israel above Middle Eastern states. While there was no explicit mention of superiority by the authors, the tone, according to Griswold, was enough to "subtly convey political and religious biases which denigrate the Muslim world in general, and Arabs in particular" (1975). While Griswold's study examined only world history textbooks, it stands out from others since it attempts to address the shortcomings found in the textbooks. Griswold's contribution is especially significant for this study because he attempted to provide what he thought to be a balanced account of the Arab-Israeli conflict by providing suggested lesson plans and resources for teaching about particular events in the conflict.

A 1976 dissertation by Samir Jarrar entitled Images of the Arabs in United States Secondary School Social Studies Textbooks: A Content Analysis and a Unit Development sought to examine how Arabs were represented in the most widely-used secondary U.S. history textbooks. The research topic was investigated using quantitative (ECO analysis in which words thought to be negative or discriminatory are coded and counted) and qualitative (an evaluation criteria checklist for each textbook) analysis methods. According to Jarrar, the results "indicated that the image of the Arab as presented in the texts is more negative than positive. This is caused by a number of factors which include omissions, stereotypes, over-generalizations, and lack of balance in the presentation of the material" (Jarrar, 1976). In addition, Jarrar asserted that the problem was only exacerbated by "continual comparisons with Israel and numerous references to isolated 
examples of extremist action by non-representative groups" (Jarrar, 1976). Jarrar recommended offering a more balanced representation of Arabs, basing information on reliable sources instead of biased interpretations, utilizing Arab scholars to help textbook publishers revise old material and write new textbooks, increasing textbook publishers' awareness of current issues facing the Arab world, and avoiding conclusive statements about the Arab-Israeli conflict since it is an ongoing source of contention. Jarrar stated that since most conclusions about the conflict "support the Israeli point of view... it is recommended that the Arab-Israeli conflict either be set aside as a major topic of study in the textbooks or be presented as much from one side as it is from the other" (Jarrar, 1976). Jarrar's suggestion is unique among the literature reviewed here; he offers no alternative ideas for publishers and educators who are unwilling to dismiss the conflict except to advise them to "solicit directly the assistance of middle eastern and Arab scholarly associations" (Jarrar, 1976).

A series of twelve journal articles were published in the Social Studies Review between the Spring of 1989 and the Fall of 1992 (Sewall, 1992). Sponsored by the American Textbook Council (ATC) and edited by Gilbert Sewall, the series was designed to provide information about and reviews of social studies textbooks. Of particular interest to this study was issue six, “The Middle East and Islam," which included the article "Textbooks and the Middle East: A Review." Three sixth grade and three high school world history texts published in 1990 were reviewed by the publication, with no explanation of how the texts were chosen. The article is only three pages, half of which are devoted to the secondary text's treatment of the history of Byzantium and Islam, the concept of "jihad," and the subject of Middle Eastern affairs since 1945. Overall, only 
one of the three books was considered "excellent" (History and Life published by Scott, Foresman). The book's treatment of Middle Eastern affairs since 1945 was considered skillful and thorough, and the topic of "Israel and the irresolution of the Palestinian problem are aptly covered" (1992). While not an academically rigorous review, the ATC's purpose in publishing these articles was to "advance history and social studies curricula by establishing a national review service for instructional materials...[and] encourage the production of textbooks that embody vivid narrative style, stress significant people and events, and reflect accurate, balanced historiographic approaches" (1992). In light of this motivation and the present study, it is interesting to note that the Council considered an understanding of Islam, the Middle East, and the Arab-Israeli conflict to be an essential part of this balanced historiographical approach.

A 1993 article by Garcia summarized various studies about ethnic groups in textbooks from the 1950s to the 1990s. While he concluded that gains were made in making textbooks more multicultural, he suggests that publishing houses have incorrectly interpreted multicultural to mean "the experiences of minority groups and women in the United States" (J. Garcia, 1993). He noted, "The quality of content describing white ethnic groups is no more informative than the content found in texts published before the 1960s" (Garcia, 1993). The white ethnic groups Garcia is referencing here, as cited earlier in his article, are Irish, Italian, Jewish, and Polish Americans. Garcia's article is a good summary of ethnic content analyses from the 1950s to the 1990s.

Barlow (1994), in conjunction with several other reviewers and the Center for Middle Eastern and North African Studies and the Middle East Studies Association, reviewed fourteen U.S. secondary history textbooks for their treatment of the Middle East 
and North Africa. While there is no explanation for how the books were chosen and many people reviewing the books have called into question the validity of the methodology used, the individual reviews of each book offer specific criticisms along with occasional suggestions for improvement. Each book is given a letter grade, ranging from "A: Use text as is, to E: Do not use this book" (Barlow, 1994). Considering the present study prompting this literature review, it is interesting to note that Barlow states in the project's introduction:

Coverage of Israel is often problematic. There is a tendency in the West to consider Israel as a Westernized country, hence like us, and hence good...In pictures and in text Israel is portrayed as modern, in contrast to the rest of the region, for which the symbol of the nomad and camel in the desert are used...Israel's conflict with the Palestinians and with other Arab states is too often explained exclusively from the Israeli point of view. Rarely does the Palestinian point of view emerge (Barlow, 1994).

From the beginning, the assumption was that textbooks are biased in favor of Israel, and evidence of this bias is based on individual reviewers' qualitative narrative analysis, with various quotations given from the text for support, although it is not clear how these quotes were chosen. Barlow's study is rare in that it was a review of U.S. rather than world history textbooks' treatment of the Middle East and North Africa.

While it only included an analysis of Israeli textbooks, Podeh's (2000) study bears mention because it was a content analysis of secondary history textbooks from 1948 to 2000 regarding presentations of the Arab-Israeli conflict as well as Arabs in general. While Podeh did consider content analysis studies of international conflicts performed on textbooks in the U.S. and other Western countries, there was no similar study of U.S. history textbooks to which he could compare his own. There were several comparable studies on Hebrew textbooks; however, Podeh's study differed from these in 
three significant ways. First, it analyzed textbooks over a period of fifty years.

Secondly, it considered the historical context influencing textbook writers at the time of textbook production. Thirdly, his research was divided into eleven main topics regarding the Arab-Israeli conflict; each topic was analyzed separately and presented chronologically. Podeh's hope in conducting the study was "that better textbooks—free of bias, prejudice, inaccuracies, and omission — on both sides of the conflict will result in a better atmosphere, congenial to the successful consummation of peaceful relations between Israel and its Arab neighbors" (Podeh, 2000). The overall finding of the study lent some weight to this goal; newer textbooks, according to Podeh, “...do indeed generate hope that the young Israeli generation will be exposed to a different kind of approach" (Podeh, 2000). Al-Haj's study of Israeli textbooks yielded similar findings (2005). This optimism was coupled with a caution, however, that new approaches must take place on both sides.

A 2004 report by the American Textbook Council (ATC) entitled Islam and the Textbooks reviewed three junior high and four high school world history textbooks published between 1994 and 2001. What Sewall labeled a "comprehensive" textbook review that began in 2001 and was still in progress at the time found "content distortions and inaccuracies that have not occurred by accident" (G. Sewall, 2004). The review examined textbook treatment of three topics: jihad, shari'a, and women. In the report's preface, the ATC stated that it was going against "thirty years of textbook advocacy in favor of sympathetic representations of Islam" (2004). As the ATC expected, the publication of its report created an immediate response, primarily from the Council on Islamic Education, which was most often the target of Sewall's criticisms. Douglass, in 
conjunction with the Council on Islamic Education, responded to Sewall's study by stating: "To begin with, it is not comprehensive, since it only deals with brief selections from six books of the dozen currently used in U.S. classrooms. He [Sewall] does not systematically compare coverage of Islam in the books, nor does he compare textbooks to mandated state curriculum standards" (2004). Of particular interest to the present study is Douglass' criticism that Sewall does not cite one textbook example relating to his accusations that Islam, Muslims, or Arabs are to blame for conflict in the Middle East; she goes on to state: "In fact, Mr. Sewall should be delighted. He would be hard pressed to find a textbook presentation of the Middle East conflict that could be construed as proArab, though some exhibit a bit more balance that they did a decade ago" (2003).

Morgan (2008) used a subjective narrative methodology to compare textbook depictions of the Middle East from 1898 to 1994. Her research surveyed textbooks from four time periods (1898-1920, 1920-1940, 1945-1965, and 1970-1994) and compared them on the topics of graphics, politics, culture, and religion (Morgan, 2008). Relying heavily on Griswold's and Barlow's earlier studies, Morgan concluded that "the Middle East has been portrayed negatively and inaccurately, and that this negative portrayal is diminishing" (2008).

Another study by the ATC and authored by Sewall (2008) entitled Islam in the Classroom: What the Textbooks Tell Us reviewed ten of the most widely-used junior and secondary high school history textbooks, although the secondary U.S. histories made up only three of the ten titles and focused exclusively on the twentieth century. The review concluded that political and religious groups try to manipulate the textbook publishing process; the most serious failure found among the textbooks was "the presence of 
disputed definitions and claims that are presented as established facts" (Sewall, 2008). Sewall employed a subjective narrative methodology in his content analysis of the textbooks, citing various textbook quotations to support his major points. Sewall's broad research questions dealt with how textbooks represent Islam's foundations and creeds, terrorism, September 11, weapons of mass destruction, Islamic challenges to global security, and future dangers to the United States and the world. He also analyzed changes between textbook materials written before 2001 and current editions of the textbooks under review. Regarding the Arab-Israeli conflict in the textbooks, Sewall noted, "Textbooks talk about 'fighting' in a neutral way rather than emphasizing decades of repeated Arab attacks on Israel. They fail to note that the Palestine Liberation Organization does not simply want a Palestinian state. Its intent is to destroy Israel" (2008). Other reviewers for this report felt that the world history textbooks in particular revealed a bias against Israel, while some felt that textbook editors intentionally avoided criticizing Israel. Sewall recommended that textbooks "summarize U.S. policy in the Middle East and outline the war against Iraq, delineating what elements of policy and war are related to Islamic fundamentalism and what elements are not" (2008).

An analysis of the results of this literature review suggests that while the ArabIsraeli conflict is a very narrow topic, it is important and calls for further study. While all of the studies included in this review agree that Jews and/or Arabs are represented one dimensionally in textbooks and that representations of the Arab-Israeli conflict are biased, the majority of those studies have been conducted using world history textbooks. More rare than studies that examine U.S. history textbooks' treatment of the Middle East are those that suggest possible curriculum and teaching solutions to provide students with 
a balanced approach, promoting critical thought about the current, seemingly intractable conflict. Also, while many of the aforementioned studies suggest that textbooks have made progress towards a more balanced representation, they also maintain that pro-Israel viewpoints remain in the curriculum (Barlow, 1994; Douglass, 2003). While Jarrar's study (1976) was an exception in that it examined U.S. history textbooks, and other studies do mention various textbook treatments of the Arab-Israeli conflict, none have looked exclusively at the Arab-Israeli conflict as represented in secondary U.S. history textbooks. The motivation for the present study, therefore, is based on the above analysis. 


\section{METHODOLOGY}

As discussed in the introduction, textbooks are important reference tools for teachers and students in U.S. classrooms. Textbooks are also valuable to researchers interested in identifying facts and concepts considered to be core content in curriculum. Combining these findings with a desire to gain a historical perspective of a topic as it has been represented within a textbook enables researchers to recognize patterns of change as well as social, cultural, and political shifts in the significance of notable topics, interpretations, and ideologies. Curriculum research can then inform educational practice by alerting educators to gaps in content at best and partial truths and distortions at worst. Understanding the causes and consequences of the Arab-Israeli conflict is essential to understanding conflict throughout the Middle East and the world. As stated in the introduction, this conflict has enormous contemporary relevance to politicians, educators, and students because it involves issues of national sovereignty, international diplomacy and security, equity, and justice.

\section{Rationale for the methodology}

How have descriptions of the Arab-Israeli conflict changed in high school U.S. history textbooks since the 1950s? The answer to this research question may be found using a qualitative content analysis methodology. According to Weber (1990), content analysis can be used for many purposes: to "identify the intentions and other characteristics of the communicator; [to] reflect cultural patterns of groups, institutions, or societies; [and to] describe trends in communication content." Additionally, Weber 
(1990) states: "A central idea in content analysis is that the many words of the text are classified into much fewer content categories." Roberts' (1997) book, in part, analyzes the earliest definitions of content analysis in methodological literature, when the practice was beginning to be recognized as a valid scientific form of research. Berelson (1952), Cartwright (1953), Janis (1949), Krippendorff (1969), Osgood (1957), and Stone (1966) were all considered pioneering researchers in content analysis methodology. Roberts (1997) categorized their basic definitions of the methodology; his work proves helpful in summarizing the various uses and desired outcomes of content analysis. Four of the six researchers believed text as well as symbolic material (e.g., symbolic behavior, communication, sign-vehicles, and messages) can be studied in content analysis. The range of results from using content analysis included description, inference, and classification. Five of the six researchers believed content analysis can go beyond the "manifest content" to the "latent content" of the material being studied, and four of the six classified content analysis as quantitative and/or qualitative. Finally, the researchers believed the descriptions and/or inferences of content analysis can apply to one or more of the following: the text, the source, and its receivers or audience (Roberts, 1997). A literature database search of "textbook" and "content analysis" yielded over 1,600 results. The method's popularity can be attributed to it being adaptable to the topic of study and to the needs of the researcher. In his Dictionary of Qualitative Inquiry, Schwandt (1997) noted that content analysis includes "both numeric and interpretive means of analyzing data." The basic inference of this study's content analysis is that the amount of space devoted to the categories of analysis determines their importance over time. Dutton (1988) observed that content analysis is most helpful when identifying trends over time, 
even stating, "when classifications are less than adequate, if used consistently over time, valuable results may appear." When content analysis became popular as a research methodology in the 1960s, a body of research surrounding historical themes, groups, and events began to emerge with treatment of groups becoming the greatest focus of the textbook studies (Siler, 1986). While the present study focuses mainly on the events of the Arab-Israeli conflict, the terms "Jew," "Jewish," "Israeli," “Arab," and "Palestinian" included in the terms of analysis could fit into the group category as well.

This thesis represents a unique approach to content analysis in relation to the Arab-Israeli conflict; an effort was made to reconstruct the educational and historical zeitgeist for each decade in order to increase the clarity of the connections between the text and its time of production. Identifying past patterns and themes allows the researcher to make inferences about future implications of curricular shifts.

Secondly, long-standing publishers that have consistently produced widely-used history textbooks since the 1950s were chosen for the study. Sewall (1992) and Foster (1999) both listed Harcourt and Houghton Mifflin in the top five publishers for the 1980s and 1990s, with Sewall's list also including Pearson in the ninth spot of top publishers for the 1980s. All three publishers included in this study have produced U.S. history textbooks that the American Textbook Council lists as having been included "in major adoptions, that, combined, hold an estimated 80 percent of the national market in U.S. and world history, grades eight to twelve." Specific textbook titles with copyright dates approximately ten years apart and that maintained similar authorship were given priority. The rationale for individual title choices was largely based on previous studies (included in Appendix A) whose researchers compiled statewide adoption lists and surveyed state 
departments of education and the nation's largest local school districts in order to identify widely-used titles.

Thirdly, key events, people, and terms relating to the Arab-Israeli conflict were identified and included in the list of topics of analysis as well as in the charts and graphs of Appendix C. An event, person, or term relating to the Arab-Israeli conflict was considered "key" if more than one textbook made reference to it. Key events included the British mandate period in Palestine, the Balfour Declaration and establishment of Israel as a nation, the 1956 Suez Canal crisis, the 1967 Six Day War, the 1973 Yom Kippur War, the 1979 Camp David Accords, the 1980s conflict in Lebanon, the 19911994 peace talks, and post 9/11 Arab-Israeli conflicts. Key people included Yasir Arafat, Menachem Begin, David Ben-Gurion, Golda Meir, Gamal Abdel Nasser, Yitzhak Rabin, and Anwar Sadat. Key terms included Arab(s), Israel and/or Israeli, Jews and/or Jewish, Palestine, and Palestinian.

Fourthly, each textbook was searched for references to the Arab-Israeli conflict, beginning with the establishment of Israel to the end of the textbook. References to people, places, and events of the conflict included index citations, timelines, pictures and their captions, chapter and unit review questions, and sentences in the main body of the text. Index references for each topic of analysis, person, or term were counted and entered into the chart in Appendix C. Pages cited more than once in the index for the same event, person, or term were not counted. Review questions were counted only if the intended answer dealt specifically with the conflict or persons involved in the conflict. Key terms and people were counted using the number of actual word occurrences in the main text, picture captions, timelines, and special boxes of text within the main body. 
Timelines and maps were counted as pictures. Finally, all sentences pertaining to the key events were counted, including sentences in special text boxes and picture captions. The data was totaled by decade and entered into the chart in Appendix C.

The final step of this study involved an analysis of the findings along with curricular implications of those findings. The recommendations and conclusions portion of the research contains suggestions for overcoming the limitations of textbook representations of the Arab-Israeli conflict.

\section{$\underline{\text { Arab-Israeli Historiography }}$}

Before presenting the qualitative analysis of each textbook's treatment of the Arab-Israeli conflict, it is important to note that the study author's knowledge of the conflict was not considered to be a baseline for this analysis; many sources were consulted. It is appropriate to acknowledge these sources, since both scholarly, historical analyses as well as works of propaganda surround this intractable struggle. The continued practice in Arab-Israeli scholarship of "scholars who tend to follow a certain school of thought or senior scholar blindly as if they were a Messiah" (Lochery, 2001) presents a real problem. Efforts to obtain sources that were as objective as possible were further complicated by the recent schism among Israeli historians along "old" and "new" lines of historic interpretation. The relationship between career advancement and "new" findings exerts pressure on Middle East historians, adversely affecting research on the Arab-Israeli conflict. Lochery (2001) provides an excellent review of works by new historians along with a summary of differences between old and new interpretations. Key differences include "the transfer of Arab refugees in 1948, the David and Goliath argument, the collusion or unwritten agreement with Jordan, the Zionist movement: 
conspiratorial or pragmatic and the responsibility for the failed peace between Israel and the Arabs." Isacoff (2005) summarized the differences of interpretation regarding these issues, stating: "Whereas the Zionists ['old' historians] depict Israel as a weak, benign victim desperately seeking to eke out an existence in the Hobbesian Middle East of the 1940s and 1950s, the new historians portray Israel as a strong, deliberate state that aggressively exploited opportunities to expropriate land and gain strategic advantage at the Arabs' expense." Prominent “old” historians, as identified by Isacoff (2005) include Anita Shapira, Avraham Sela, Efraim Karsh, and Michael Oren. Benny Morris, Avi Shlaim, and Ilan Pappe are acknowledged as the "new" historians' founders, with Yoav Peled, Gershon Shafir, Motti Golani, Uri Ram, Yagil Levy, and Uri Ben-Eliezer as important contributors. Taking this into consideration, the following sources were consulted (some more heavily than others) when analyzing the textbooks included this study:

Avneri, A. (1984). The claim of dispossession: Jewish land settlement and the Arabs 1878-1948 (Kfar-Blum Translation Group). New Brunswick: Transaction Books. Barari, H. (2009). Israelism: Arab scholarship on Israel, a critical assessment. Reading, United Kingdom: Ithaca Press.

Bickerton, I., \& Klausner, C. (2005). A concise history of the Arab-Israeli conflict (Fourth ed.). New Jersey: Prentice Hall.

Carol, S. (2008). Middle East rules of thumb: Understanding the complexities of the Middle East (2nd ed.). New York: iUniverse, Inc.

Gelvin, J. (2005). The Israel-Palestine conflict: One hundred years of war. New York: 
Cambridge University Press.

Gilbert, M. (2005). The routledge atlas of the Arab-Israeli conflict. New York: Routledge.

Herzog, C. (1982). The Arab-Israeli wars. London: Arms and Armour Press.

Isacoff, J. (2005). Writing the Arab-Israeli conflict: Historical bias and the use of history in political science. Perspective on Politics, 3(1), pp. 71-88.

Lea, D., \& Rowe, A. (Eds.). (2002). A survey of Arab-Israeli relations 1947-2001 (First Edition). London: Europa Publications.

Reich, B., Goldberg, J., Gotowicki, S., Silverburg, S., \& Erickson, M. (Eds.). (1996). An historical encyclopedia of the Arab-Israeli conflict. Westport, Connecticut: Greenwood Press.

Smith, C. (2010). Palestine and the Arab-Israeli conflict (Seventh Edition). Boston: Bedford/St. Martin's. 


\section{RESULTS}

The following categories of analysis include only a summary of findings from all of the textbooks and decades included in this study. For more detailed analysis of each textbook within each decade, see Appendix B. A one to three rating has been assigned to each textbook from each decade and for each category of analysis. A "three" rating identifies the textbook from each decade that best addresses the category of analysis under study and a "one" indicates the least adequate textbook for the category of analysis under study. Textbooks with a "three" rating were considered the most thorough of the three books under study for each decade and the textbook that leaves the least amount of perspectives, questions, and theories unacknowledged and/or unanswered. Beside the number rating is a notation indicating whether the textbook's summary for that category of analysis was considered to be generally pro-Israel ("P"), anti-Israel ("A"), or mostly neutral ("N"). An "X" indicates the absence in the textbook of the category of analysis under study.

\section{Category of Analysis}

\section{Mandate System/Balfour Declaration/1948 War/Establishment of Israel: (See} Appendix B pp. 147-167 for edition specific information)

\section{1. "What are the underlying problems which have generated this discourse"} (Larsen, 1991)?

ALL DECADE SUMMARY: The Cold War is undoubtedly the dominant underlying problem that prompts discussion of the Middle East in these textbooks. Palestine and 
Israel's independence is repeatedly seen in the light of East-West conflict and strategic importance. A focus on British decline in the Mediterranean is a secondary theme in the early textbooks, while the region's oil reserves become the secondary focus beginning in the 1980s. The root of the conflict over the land itself, between Jews and Arabs, is not readily apparent until the textbooks of the 1990s and 2000s.

\section{What theories provide the descriptions and explanations thought to be relevant?}

ALL DECADE SUMMARY: Worldwide and American sympathy for Jews after World War II and the Holocaust is the dominant theory leading to descriptions and explanations about the establishment of Israel. The difficult diplomatic position of the U.S. between supporting Israel and maintaining relations with oil-rich Arab nations is also a theme. Great Britain's abdication of its mandate in Palestine is typically seen as the impetus for Israel's declaration of statehood; Zionism and its influence over the events leading up to 1948 are not mentioned in textbooks until the 1990s.

\section{What relationships, causes, and consequences are proposed?}

ALL DECADE SUMMARY: The dominant theme or relationship throughout the textbooks is the Arab nations' hatred toward Israel, before and after the 1948 War. Specifically, the Arab nations' refusal to accept Israel as a state is repeatedly mentioned, although reasons why are not always provided. Ben-Gurion's leadership as well as Dr. Bunche's UN negotiations are frequently mentioned. Primary causes leading to the outbreak of the 1948 War are Great Britain's end of the mandate period and the UN Partition Plan, although many times no cause for the 1948 War is given. Key consequences addressed in the textbooks include the 1948 War, the Arab nations' 
continued hatred for Israel, and an uneasy peace. Beginning in the 1990s, some texts mention refugees remaining in Palestine after the 1948 War.

\section{On what premises is the account based and what assumptions are made in the course of the explanation (Larsen, 1991)?}

ALL DECADE SUMMARY: The premises for this question are more varied than others. Premises for textbook accounts of the 1948 War include American sympathy for Jews after World War II, the difficult diplomatic position of the U.S. in the Middle East, Cold War tensions, Arab hostility toward Jews and Israel, general threats to world peace, and maintaining world peace.

A major assumption in many texts is that all Americans sympathized with Jews

after World War II, as did the world. Because many accounts of the mandate period and 1948 War were within a Cold War context, the implicit assumption was that Middle East affairs were important only as much as they related to Cold War strategy. Varied statements about who actually declared Israel an independent state can be observed, including the UN, President Truman, and David Ben-Gurion; however, some texts do not include this information at all. The texts varied greatly in their descriptions of the peace negotiations following the 1948 War. Texts that did not include peace negotiations often left students with the assumption that Israel's victory was decisive and accepted in the Arab world and that peace was immediate with no unresolved issues. Texts that did include peace negotiations typically excluded unresolved issues between the two sides.

5. What perspectives, questions, and theories are not acknowledged (Larsen, 1991)?

ALL DECADE SUMMARY: The first question often left unaddressed is why Great Britain gave up its mandate in Palestine. This question is not addressed until the 1990s 
and is rarely mentioned at all. Even though many texts mention the Jews' desire for a national homeland, very few delve into the reasons why. Zionism and its influence in this area are only found in textbooks from the 1990s onward. Regarding immigration, no texts address the 1939 White Paper and continued limits on Jewish immigration to Palestine even after World War II. The most glaring exclusions and gaps in information are seen in textbook content on the UN Partition Plan and root causes of the 1948 War. The fact that Arab states were angered by Israel's declaration of statehood is almost always included, but why the establishment of Israel angered the Arab world and which Arab states went to war with Israel are excluded. Peace negotiations after the war are often absent, and if present, focus on Dr. Ralph Bunches' efforts on behalf of the UN. Only a few mention that his predecessor was assassinated for similar efforts and none give any reasons for why he was assassinated, although two textbooks mention he was killed at the hands of Israeli extremists. Issues of contention left unresolved by peace negotiations are not included until the 1980s and later. Even when Arab refugees remaining in Israel after 1948 are mentioned, Jewish refugees from Arab countries during the same period are never mentioned. Although one text mentions competing claims about whether the Arab refugees fled or were driven out of Israel, it avoids a conclusive statement on the matter. Finally, although the Arab states' continued refusal to recognize Israel as a state is often included, the reasons why are not.

\section{All Decade Summary: Mandate System/Balfour Declaration/1948}

War/Establishment of Israel: (See Appendix C pp. 263-264 for Mandate/1948 graphs) 


\begin{tabular}{|c|c|c|c|c|c|c|c|}
\hline Publisher & $1950 \mathrm{~s}$ & $1960 \mathrm{~s}$ & $1970 \mathrm{~s}$ & $1980 \mathrm{~s}$ & $1990 \mathrm{~s}$ & $2000 \mathrm{~s}$ & Totals \\
\hline HM & $\mathrm{X}$ & $\mathrm{X}$ & $2(\mathrm{P})$ & $1(\mathrm{P})$ & $\mathrm{X}$ & $1(\mathrm{~A})$ & $\mathbf{4}$ \\
\hline HOLT & $2(\mathrm{~N})$ & $3(\mathrm{~N})$ & $3(\mathrm{~N})$ & $2(\mathrm{~N})$ & $3(\mathrm{P})$ & $3(\mathrm{P})$ & $\mathbf{1 6}$ \\
\hline PH & $3(\mathrm{P})$ & $2(\mathrm{~A})$ & $1(\mathrm{~A})$ & $3(\mathrm{~A})$ & $2(\mathrm{~N})$ & $2(\mathrm{~N})$ & $\mathbf{1 3}$ \\
\hline
\end{tabular}

Category of Analysis

Category of Analysis

1956 Suez War: (See Appendix B pp. 167-193 for edition specific information)

1. "What are the underlying problems which have generated this discourse"

(Larsen, 1991)?

ALL DECADE SUMMARY: The predominant underlying problem in all of the textbooks is the Cold War competition between the U.S. and Soviet Union for influence in the Middle East. Secondary problems mentioned mostly in the early textbooks include Egypt's diplomatic bargaining with the East and West and operation and control of the Suez Canal itself; two early textbooks also mention that Arab nationalism contributed to growing Cold War tensions. There are significant changes in the way underlying problems are represented in the textbooks over the decades. Early texts not only blame Cold War tensions for trouble in the Middle East but also include general Arab unrest and Arab nationalism. Later books have much less detail about Nasser and his bargaining with both the East and West for weapons and Aswan Dam financing. Oil is first mentioned in the 1986 Holt edition, and by the time of the 2000s textbooks, Cold War tensions seem to be downplayed, replaced by a focus on control of the Suez Canal and the effects this had on oil distribution.

2. What theories provide the descriptions and explanations thought relevant? 
ALL DECADE SUMMARY: Most textbooks use Cold War theory to provide context for descriptions and explanations. Some also use Nasser's nationalization of the Suez Canal as a focal point leading to follow-up descriptions and explanations. Only a few early textbooks put Nasser's decision into historical context with explanation of the diplomatic nuances surrounding the Aswan Dam financing that led to the nationalization of the canal. A few early textbooks spend more time on the Middle East Treaty Organization and the U.S.' delicate diplomatic balance between Arab support (oil) and sympathy for Israel. These same texts rarely mention the formation of the Arab League as a result of the Suez War.

\section{What relationships, causes, consequences are proposed?}

ALL DECADE SUMMARY: One relationship evident in most textbooks is Nasser's anger when the U.S. withdrew Aswan Dam financing, but even those textbooks that do not include information on the Aswan Dam typically mention Nasser's nationalization of the Suez Canal being contrary to U.S. goals in the region. Another predominant relational theme is the U.S. reaction to its NATO allies' (Britain and France) invasion of Egypt; words used to describe this reaction include consternation, embarrassment, and even shock. Early texts spend more time on the strain this caused among NATO relationships and the fact that the U.S. was forced to side with the Soviet Union in calling for a cease-fire. Later textbooks spend less time on the implications for NATO and more focus on UN efforts to bring about the cease-fire. Causes for the cease-fire in early textbooks seem to center on the threats made by the Soviet Union to use military force, while later textbooks do not mention these threats and place responsibility for the ceasefire with UN efforts. 
Early textbooks contextualize the Suez War with information on Nasser's and/or Egypt's anti-Western sentiments, although many times specific "sentiments" are not listed. Later textbooks emphasize Nasser's actions to nationalize the Suez Canal and the events that action set into motion. Only one text (HM 1975) states that the conflict was primarily between Israel and Egypt. Early textbooks identify Israel's attack as the spark that motivated Britain and France to involve themselves; later textbooks downplay Israel's unilateral involvement and stress Britain, France, and Israel's cooperative involvement in light of larger Cold War tensions. Interestingly, PH 2005 does not even mention Israel in its account of the Suez War.

Almost every textbook listed the Eisenhower Doctrine as the primary result of the Suez War from a U.S. perspective. Many textbooks also include information on the enhanced position of the Soviet Union in the Middle East after the Suez War.

\section{On what premises is the account based and what assumptions are made in the course of the explanation (Larsen, 1991)?}

ALL DECADE SUMMARY: Almost without exception, the premise of each textbook's account of the Suez War is the Cold War and American competition for influence in the Middle East. Two areas of assumption in the textbooks dealt with the cooperation among Israel, France, and Great Britain, as well as Israel's motivations for attacking Egypt.

Surprisingly, the $1957 \mathrm{PH}$ text does imply possible collusion among Britain, France, and Israel in the attack on Egypt, but the rest of the 1960s and 1970s textbooks imply no cooperation among the countries. Textbooks in the 1980s shift toward the opposite assumption, that there was cooperation. By the 1990s, when textbooks include 
France and Britain's efforts to get Israel and Egypt to agree to a cease-fire, it is submitted as the excuse France and Britain needed to join the attack, not as a sincere attempt at peace.

Israel's motivations for attack vary by publisher and decade. While a few textbooks do not include any clear reason why Israel attacked Egypt, and the PH 2005 textbook does not even include Israel's involvement in the Suez War, most include at least one reason for the attack. The reason cited most often beginning in the 1950s and continuing to the 2000s is Egypt's decision to close the Suez Canal to Israel. Only a few textbooks include the fact that this closure was also contrary to international law. Another interesting nuance is the observation that early textbooks that include the canal closure typically state that it was closed to "Israeli ships," while later textbooks state that the canal was closed to "ships bound for Israel." It is difficult to generalize additional reasons for Israel's involvement that were included in the texbooks. PH 1957 and 1967 include Israel's stated mission to destroy bases in Egypt from which "Egyptian raids" had been launched into Israeli territory, while HM 1996 mentions "terrorist raids" launched by Egypt into Israeli territory. From the 1960s to the 1980s, Holt maintains that Israel's attack was made in order to "forestall” Egypt's planned attack on Israel. This reasoning is not found in their 1995 and 2003 editions. HM 1962 and 1975 give no reasons for Israel's involvement, saying the attack was "sudden" and "unfair," while the PH 1976 edition bases Israel's involvement only on "rising tensions" in the region. Considering all of the textbooks together, the canal closure is most often the only reason given for Israel's involvement in the Suez War.

\section{What perspectives, questions, theories are not acknowledged (Larsen, 1991)?}


ALL DECADE SUMMARY: Aside from the earliest textbooks, most make no mention of the arms buildup or events in Egypt and Israel prior to the Suez War that would provide historical context for tensions between the two nations. Nasser's goals for Egypt and the Arab world and his motivations for bargaining with the U.S. and Soviet Union are mentioned in some early textbooks, but in later textbooks these goals and actions are either shortened to the all inclusive phrase "anti-Western gestures" or not included at all. Later texts often exclude the diplomatic and financial negotiating over the Aswan Dam, thereby excluding important information like why the U.S. was willing to finance the dam and why the offer was eventually withdrawn. When texts do mention the withdrawn financing offer, reasons vary from text to text. Some mention Nasser's anti-Western gestures, though few are explicit about what that means (PH 1957 and 1967); some state it was simply because Nasser also turned to the Soviet Union; and early texts state that it was because the U.S. discovered the Soviet Union could not actually afford to finance the project (Holt 1966 and 1977).

Early texts do provide one reason why Nasser decided to nationalize the Suez Canal (withdrawal of financing), but later texts explain what that actually meant and how Nasser intended to use the tolls (to finance the dam). While many texts state that Nasser closed the canal to Israeli access, only one gives any sort of explanation for this decision: "Egypt had closed the canal to Israeli shipping, and, along with other Arab states, had vowed to drive Israel into the sea" (HM 1962). International reaction to nationalization of the canal is typically not included; however, U.S. reaction to Britain, France, and Israel's invasion of Egypt is almost always included. Early texts include more detail on cease-fire negotiations and the Soviet Union's threats to use military force if Britain, 
France, and Israel did not withdraw. Interestingly, only one text mentions a counterthreat made by the U.S. that this type of intervention would not be acceptable (HM 1996). Later texts treat the Suez War less like a "brink of war" threat and more like a Cold War trouble spot for East/West relations. Most texts exclude who controlled the canal at the end of the war.

ALL DECADE SUMMARY: 1956 Suez War (See Appendix C p. 265 for chart)

\begin{tabular}{|c|c|c|c|c|c|c|c|}
\hline Publisher & $1950 \mathrm{~s}$ & $1960 \mathrm{~s}$ & $1970 \mathrm{~s}$ & $1980 \mathrm{~s}$ & $1990 \mathrm{~s}$ & $2000 \mathrm{~s}$ & Totals \\
\hline HM & $\mathrm{X}$ & $1(\mathrm{P})$ & $1(\mathrm{~A})$ & $2(\mathrm{P})$ & $3(\mathrm{P})$ & $2(\mathrm{~N})$ & $\mathbf{8}$ \\
\hline HOLT & $\mathrm{X}$ & $3(\mathrm{~A})$ & $2(\mathrm{~A})$ & $3(\mathrm{~A})$ & $2(\mathrm{~N})$ & $3(\mathrm{~N})$ & $\mathbf{1 3}$ \\
\hline PH & $1(\mathrm{P})$ & $2(\mathrm{~A})$ & $3(\mathrm{~A})$ & $\mathrm{X}$ & $\mathrm{X}$ & $1(\mathrm{~A})$ & $\mathbf{7}$ \\
\hline
\end{tabular}

\section{Category of Analysis}

1967 Six Day War: (See Appendix B pp. 193-204 for edition specific information)

\section{1. "What are the underlying problems which have generated this discourse"}

\section{(Larsen, 1991)?}

Underlying problems for the Six Day War are fairly consistent, yet vary with each publisher. For HM, fighting simply broke out between Israel and the Arab states, and underlying problems are not discussed. Holt cites Israel's belief that Arab states intended to destroy Israel, along with Soviet arms supplied to the Arab states and American arms supplied to Israel prior to 1967 . PH typically also cites the Soviet involvement, with the added detail that this act encouraged Nasser's militancy and troop increase in the Sinai Peninsula. Interestingly, Holt was the only publisher to mention the Six Day War in a 1990s edition; none of the publishers mention the conflict in the 2000s editions. 


\section{ALL DECADE SUMMARY:}

\section{What theories provide the descriptions and explanations thought relevant?}

Similar to above, HM leaves out theory related to the cause of the Six Day War as well as consequences of the conflict. Holt cites both sides' arms buildup prior to the conflict, raids by the Arab states with counterstrikes by Israel, and Israel's belief in Egypt's hostile attentions as causes. One Holt text also mentions the Arabs' loss of territory during the Six Day War as a continued source of bitterness. PH most thoroughly explained Israel's perspective and gave reasons for their preemptive strike, including Nasser's militancy and troop movement in the Sinai Peninsula.

\section{ALL DECADE SUMMARY:}

\section{What relationships, causes, consequences are proposed?}

The most frequently mentioned relationship is the Arab states' bitterness toward Israel, both before and after the Six Day War. A secondary detail mentioned in some of the texts is Israel's total, or as one text phrased it, "crushing" victory in the conflict (Holt 1995). In the two HM textbooks (1975 and 1986), no cause for the conflict is given. Holt went through significant changes regarding the cause of the war. The 1977 edition cites raids by both sides and the Arab nations' massing of military forces; the 1986 edition cites Israel's belief that Arab nations wanted to destroy their state; and the 1995 edition gives no cause at all. The two PH texts include only the 1976 and 1986 editions. The earlier text cites Nasser's militancy as the cause, while the later textbook includes arms being supplied to both sides along with Egyptian troop buildup in the Sinai Peninsula. Consequences in the HM textbooks were very general and included increased Arab hostility and a situation that was "more tense than before" (HM 1986 p. 691). 
Holt's consequences in the 1977 and 1986 editions were fairly thorough (Israel's land acquisitions, Arab bitterness, Arab raids into Israel, Arab arms buildup after the war), but many were edited from the 1995 edition; this textbook gave no conclusion or consequence, mentioning only that the Arab-Israeli conflict was "simmering" in the Middle East (Holt 1995 p. 904). Prentice Hall's 1976 edition includes Egypt's humiliation and enhanced Soviet prestige in the Middle East as consequences, while the 1986 edition highlights Israel's defeat of Egyptian forces in the Sinai and capture of territory in Jordan and Syria.

\section{ALL DECADE SUMMARY:}

\section{On what premises is the account based and what assumptions are made in the course of the explanation (Larsen, 1991)?}

Houghton Mifflin's premise in the 1975 and 1986 texts is that Johnson faced many international conflicts during his administration. The Six Day War is depicted as another diplomatic challenge that took a back seat to the Vietnam War during his administration. Holt's 1977 text is more general; the Middle East had long been and would continue to be an international trouble spot. However, the 1986 and 1995 editions place the Six Day War in the context of détente and the challenge that the Middle East represented to this American diplomatic policy. Prentice Hall's premise centers on the U.S.' diplomatic balance between Israel and the Arab states and the new reality that oil was a powerful political and economic weapon. Assumptions included in one or more of the texts were that fighting simply broke out between Israel and the Arab states, that UN troops were the only entitity keeping the two sides apart, that Israel's belief that Arab states were massing military troops and arms to destroy Israel was unfounded or possibly 
that this belief was not widely acknowledged internationally, that the conflict was unimportant because it did not directly involve Americans, and lastly, that a peaceful resolution to the Arab-Israeli conflict was unlikely.

\section{ALL DECADE SUMMARY:}

\section{What perspectives, questions, theories are not acknowledged (Larsen, 1991)?}

It would be easier to list what was acknowledged about this conflict in the textbooks since the information was so sparse, but listed here are some of the major historical and contextual pieces of information left out in most of the textbooks. First, only Israel and Egypt were listed as participants in the fight, excluding the other Arab states who joined with Egypt. The fact that Egypt, Jordan, and Syria were divided politically on almost everything but their hatred of Israel is never mentioned, making the agreements between the three countries seem less than the extraordinary alliance that it was. The U.S. decision to become Israel's primary arms supplier and Soviet Union arms shipments prior to the war are almost never mentioned. Other than sentiments about oil in two texts, international reaction to the conflict is absent. In some cases, the results and official victor of the conflict are not included, only that the situation in the Middle East had worsened. Egypt's (Nasser's) motivation for moving troops into the Sinai Peninsula is never included, and specific territories that Israel captured in the conflict are never mentioned, only that the territory previously belonged to Egypt, Jordan, and Syria. The Six Day War significantly decreased in importance with each textbook edition, discussed in only one 1990s textbooks and none of the 2000s.

ALL DECADE SUMMARY: 1967 Six Day War (See Appendix C p. 266 for chart) 


\begin{tabular}{|c|c|c|c|c|c|c|c|}
\hline Publisher & $1950 \mathrm{~s}$ & $1960 \mathrm{~s}$ & $1970 \mathrm{~s}$ & $1980 \mathrm{~s}$ & $1990 \mathrm{~s}$ & $2000 \mathrm{~s}$ & Totals \\
\hline HM & $\mathrm{X}$ & $\mathrm{X}$ & $1(\mathrm{~N})$ & $1(\mathrm{~N})$ & $\mathrm{X}$ & $\mathrm{X}$ & $\mathbf{2}$ \\
\hline HOLT & $\mathrm{X}$ & $\mathrm{X}$ & $2(\mathrm{~A})$ & $2(\mathrm{~A})$ & $1(\mathrm{~A})$ & $\mathrm{X}$ & $\mathbf{5}$ \\
\hline PH & $\mathrm{X}$ & $\mathrm{X}$ & $3(\mathrm{~N})$ & $3(\mathrm{~N})$ & $\mathrm{X}$ & $\mathrm{X}$ & $\mathbf{6}$ \\
\hline
\end{tabular}

\section{Category of Analysis}

1973 Yom Kippur War: (See Appendix B pp. 204-223 for edition specific information)

\section{1. "What are the underlying problems which have generated this discourse" \\ (Larsen, 1991)?}

Two predominant underlying themes are extant in the texts, with some exceptions. First, early texts (1970s and 1980s) focus on the Cold War and view the Yom Kippur War as the first successful test of Soviet and American attempts at détente; second, later texts (1990s and 2000s) focus on American dependence on foreign oil and the economic crisis that the October War created for the American economy in particular, although PH 1976 first mentions the oil embargo and economic ramifications for the U.S. Secondary problems include the continuing military supply shipments from the Soviet Union and the U.S. to their Middle Eastern allies (Egypt and Israel, respectively) (HM 1975), Egypt and Syria's lost territory from 1967 (PH 1986), and continued border disputes between Israel and its Arab neighbors (HM 2005).

\section{ALL DECADE SUMMARY:}

\section{What theories provide the descriptions and explanations thought relevant?}

Early text theories involve Soviet and U.S. arms supplies to Egypt and Israel, along with their powers of persuasion over their respective Middle Eastern allies 
involving cease-fire negotiations. With the exception of Holt (1995), which mentions lost Arab territory in 1967, later texts generally provide less historical context for the Yom Kippur War. However, later texts still emphasize America's support for Israel and dependence on foreign oil. Most texts, even early on, make the connection between the Arab oil embargo and the 1973 conflict. With the exception of HM (1975), when texts do mention negotiations and opportunities for peace in the region, texts throughout the decades are not hopeful about the possibility for long-term peace in the region.

\section{ALL DECADE SUMMARY:}

\section{What relationships, causes, consequences are proposed?}

Two relationships appear most often in the majority of the texts. First is the alliance between Egypt and Syria (although most texts do not mention why the two nations cooperated in their attack on Israel); the second is American military aid to and diplomatic support for Israel. Six texts also highlight Arab anger at America's friendship with Israel, and five mention Kissinger's diplomatic efforts on behalf of both sides.

A majority cause for the 1973 conflict is not found in the texts. Five (HM 1975, 1986, 1996, PH 1976, 1995) give no cause at all; three (HM 1975, 1986, PH 1986) only imply that American and Soviet arms shipments to the region encouraged the conflict; and four (Holt 1977, Holt 1986, PH 1986, and Holt 1995) mention lost Egyptian and Syrian territory during the 1967 Six Day War with Israel. The cause of the Arab oil embargo is very clear in later texts; it was a result of American support for Israel during the Yom Kippur War.

Undoubtedly, the most frequently mentioned consequence of the 1973 conflict is the Arab oil embargo, with later texts also delineating the specific consequences the 
embargo had on the American economy (economic recession, inflation, unemployment). Aside from the embargo, there is no majority consensus in the texts regarding consequences of the Yom Kippur War. Early texts mention Israeli bitterness at being forced to end the fighting before a decisive victory (Holt 1977, 1986), Arab anger at American support for Israel (Holt 1977, 1986), and American diplomatic pressure on Israel to return "occupied" lands from the 1967 Six Day War (PH 1986). Later texts highlight the fact that even after the embargo, the price of oil remained high, and two texts (HM 2003, PH 2005) focus on Kissinger's diplomatic success, coordinating a ceasefire and peace negotiations (although the peace negotiations are never discussed in the text).

\section{ALL DECADE SUMMARY:}

\section{On what premises is the account based and what assumptions are made in the course of the explanation (Larsen, 1991)?}

The premise was different, yet consistent throughout the decades for each publisher. Houghton Mifflin viewed the October War simply as another conflict in the long history of tensions in the region, acknowledging in its 2003 edition that, although it was short, it was a very brutal war. Holt's premise maintained that the conflict was the first, successful test of détente between the U.S. and Soviet Union, although its 2003 edition focused only on the fragility of the American economy because of its dependence on foreign oil. Prentice Hall's primary premise was the search for peace in the Middle East, acknowledging that no easy solution had yet been found. Like Holt, its 2005 edition focused mainly on the American economy's dependence on foreign oil. 
Assumptions found in early textbooks include "occupied lands" and refugees as stumbling blocks to peace (PH 1986); that the conflict did nothing to change the status quo in the region (PH 1986); U.S. and Soviet involvement only extended to cease-fire and peace negotiations (Holt 1986); and the conflict was unique because Israel was not the aggressor (HM 1986). Later texts (with one exception) imply that the conflict was only important because it affected American oil supplies (PH 1976, Holt 2003, PH 2005), or texts assume that students already know about the Yom Kippur War and only list it as one of the many conflicts in the region (HM 1996, PH 1995).

\section{ALL DECADE SUMMARY:}

\section{What perspectives, questions, theories are not acknowledged (Larsen, 1991)?}

With a few individual exceptions, all publishers and decades leave some perspectives, questions, and theories unacknowledged. The historical context prior to the war or even initial causes of the breakdown in peace among Egypt, Syria, and Israel is not included. Motivations for why Syria and Egypt formed an alliance are excluded. There is no mention of Yom Kippur or the significance for the date of the surprise attack on Israel. Actual locations of the fighting (Suez Canal, Sinai, Golan Heights) are excluded. Other notable exclusions are the death of Nasser and succession of Sadat in Egypt; the breakdown of relations between Egypt and the Soviet Union prior to the war; the PLO's increased importance in Middle East diplomacy; the ever-changing international opinion toward Palestinians (positive) and Israel (negative); Israel's technical military victory and the Arab states' psychological victory; international reaction to the Arab oil embargo and why OPEC eventually lifted the embargo; growing international awareness of the Arab-Israeli conflict along with America's increased 
influence in the region; and finally, details of cease-fire and peace negotiations among Israel, Syria, and Egypt are never included. Kissinger's shuttle diplomacy is mentioned, but only in half of the texts.

ALL DECADE SUMMARY:

1973 Yom Kippur War (See Appendix C p. 267 for chart)

\begin{tabular}{|c|c|c|c|c|c|c|c|}
\hline Publisher & $1950 \mathrm{~s}$ & $1960 \mathrm{~s}$ & $1970 \mathrm{~s}$ & $1980 \mathrm{~s}$ & $1990 \mathrm{~s}$ & $2000 \mathrm{~s}$ & Totals \\
\hline HM & $\mathrm{X}$ & $\mathrm{X}$ & $2(\mathrm{P})$ & $1(\mathrm{~N})$ & $1(\mathrm{~A})$ & $3(\mathrm{P})$ & $\mathbf{7}$ \\
\hline HOLT & $\mathrm{X}$ & $\mathrm{X}$ & $3(\mathrm{P})$ & $3(\mathrm{P})$ & $3(\mathrm{P})$ & $1(\mathrm{~N})$ & $\mathbf{1 0}$ \\
\hline PH & $\mathrm{X}$ & $\mathrm{X}$ & $1(\mathrm{~N})$ & $2(\mathrm{~A})$ & $2(\mathrm{~N})$ & $2(\mathrm{~A})$ & $\mathbf{7}$ \\
\hline
\end{tabular}

\section{Category of Analysis}

1979 Camp David: (See Appendix B pp. 224-240 for edition specific information)

\section{1. "What are the underlying problems which have generated this discourse" (Larsen, 1991)?}

\section{ALL DECADE SUMMARY:}

In the nine texts studied for this topic of analysis, three underlying problems were apparent, although only one or two were addressed in each textbook at a time. Five out of nine texts described the Middle East as generally "troubled," "unstable," and a region of "long-time" conflict between Egypt and Israel (Holt 1986, HM 1996, PH 1995, Holt 2003, PH 2005). A second impetus for Camp David was Carter's desire to find a peaceful solution in the Arab-Israeli conflict and address human rights for Palestinians (HM 1986, PH 1995, PH 2005). Two texts mention the breakdown of prior peace talks as a problem leading into Camp David (PH 1986, Holt 1995). Interestingly, four texts 
mention Arab anger at Sadat for attempting peace talks with Israel (Holt 1986, PH 1986, HM 1996, Holt 1995).

\section{What theories provide the descriptions and explanations thought relevant?}

\section{ALL DECADE SUMMARY:}

The most predominant theory regarding Camp David, found in seven of nine texts, described the negotiations as Carter's chief foreign policy triumph and a result of his personal efforts to keep the talks from breaking down again (Holt 1986, PH 1986, HM 1986, PH 1995, HM 2003, Holt 2003, PH 2005). Only one text attempts to address why previous talks were unsuccessful, stating that it was because Sadat and Begin had such "different personalities" (PH 1995). Secondary theories among the texts include fighting for land and official Arab recognition of Israel (HM 1996), U.S. promises to Israel of advanced weaponry in exchange for returning the Sinai to Egypt (HM 1996), and, according to one text, Sadat's initiation and primary interest in peace; there was no mention of a troubled peace process or unresolved issues, only the resulting Nobel Peace Prize for Begin and Sadat (Holt 1995).

\section{What relationships, causes, consequences are proposed?}

\section{ALL DECADE SUMMARY:}

The most obvious relationship, found in five out of the nine texts, is Carter's role as mediator between Begin and Sadat (HM 1986, PH 1986, PH 1995, HM 2003, PH 2005). Four texts also mention Arab anger with Sadat for negotiating with Israel (Holt 1986, PH 1986, HM 1996, Holt 1995). Only three texts hint that negotiations between Sadat and Begin were difficult (PH 1986, HM 2003, PH 2005). And only one mentions 
the "historic antagonism" between Egypt and Israel (HM 1996). Only one text reminds readers of American dependence on foreign oil at this point (Holt 1986).

The most commonly cited cause for the Camp David negotiations, found in seven of the nine texts, is stalled peace talks in prior attempts at negotiation (Holt 1986, $\mathrm{PH}$ 1986, HM 1996, Holt 1995, PH 1995, Holt 2003, PH 2005). Four out of nine texts mention Carter's desire for peace in the region as a cause for Camp David (HM 1986, PH 1995, HM 2003, PH 2005), and three texts cite Sadat's visit as the impetus (PH 1986, HM 1986, Holt 1995).

Consequences of Camp David vary broadly among the texts. The most common, found in six of the nine texts, is Israel's return of the Sinai Peninsula to Egypt (Holt 1986, PH 1986, HM 1996, PH 1995, HM 2003, PH 2005). The second most common consequence, found in four out of the nine texts, is Israel's official recognition of statehood from Egypt (HM 1996, PH 1995, HM 2003, PH 2005). Beyond these two consequences, texts begin to vary in their results of Camp David. Three texts mention Sadat's assassination ( $\mathrm{Ph}$ 1986, HM 1996, Holt 1995); three mention unresolved issues over "occupied lands" and a Palestinian homeland (Holt 1986, PH 1995, PH 2005); and three simply mention that Camp David was the first official agreement between an Arab nation and Israel (HM 1986, PH 1986, HM 2003). Two texts mention the Nobel Peace Prize (Holt 1995, Holt 2003), and two mention that Camp David established a process for future peace talks (PH 1995, Holt 2003). The following consequences are listed in only one text: the continued threat of war (Holt 1986), PLO terror raids in Israel and Israel's response (HM 1996), criticism of Carter for favoring Arab nations over Israel (Holt 1995), Israel and Egypt's pledge to work toward a Palestinian solution (PH 1986), and 
mention of the two specific agreements that came out of Camp David, along with the terms for each (HM 1996).

\section{On what premises is the account based and what assumptions are made in the course of the explanation (Larsen, 1991)?}

\section{ALL DECADE SUMMARY:}

The premise in most of the texts relates to Carter - his desire for peace and stability in the Middle East (HM 1986, PH 1995, PH 2005) and that Camp David was his greatest diplomatic triumph (Holt 1995, HM 2003, Holt 2003). Two texts saw Camp David as an extraordinary step toward peace that still left unresolved issues (Holt 1986, PH 1986), while one simply saw it as an extension of Kissinger's shuttle diplomacy (HM 1996).

Assumptions vary greatly from text to text, and if found, are typically only included in one text: War remained a constant threat after Camp David (Holt 1986); Carter favored the Arab states in negotiations (Holt 1986); the major point of contention at Camp David was the return of the Sinai to Egypt (PH 1986); there were "signs" in the 1980s that moderate Arab states were willing to follow Sadat's example and enter into peace agreements with Israel (PH 1986); many people were cheered by the news of Camp David (HM 1996); Sadat played a more active role than Begin (Holt 1995); prior negotiations failed because Sadat and Begin had different personalities (PH 1995, PH 2005); Camp David succeeded because of Carter's personal diplomacy (PH 1995, PH 2005); it was the U.S. policy to mainly support Israel at Camp David while trying to resolve the Palestinian issue (HM 1996). Lastly, it was assumed that students already knew which issues were that left "unresolved" by Camp David (HM 2003). 


\section{What perspectives, questions, theories are not acknowledged (Larsen, 1991)?}

The following list includes information that none of the textbooks addressed: Begin's motivations for negotiating; Carter's call for a "Palestinian homeland" in March of 1977; Carter's departure from step-by-step diplomacy and preference for more comprehensive diplomatic action; with the exception of HM 96, none of the textbooks mention that there were two separate agreements between Egypt and Israel, and none of the texts include the actual titles for those agreements; the avoidance of the dispute surrounding Jerusalem and the Golan Heights in the Accords; disagreement within the PLO about a compromise Palestinian state in the West Bank and Gaza; reasons why Israel was willing to give up the Sinai Peninsula but not the West Bank or Gaza; Egyptian and American hopes that Jordan would be drawn into the negotiations; motivating factors that led Egypt and Israel to make concessions in the negotiations; Egypt's reaction to the Camp David Accords; and increased Arab suspicion of Israel and the U.S. because of Camp David.

The following list includes information not included in six or more textbooks: the date of the signing of the peace accords; Sadat's motivations for negotiating; specific conditions of each peace agreement within the Camp David Accords; U.S. reaction to Camp David; the Arab world's reaction to Camp David; Sadat's assassination, reasons for it, and who assassinated him.

The following list includes information not included in four textbooks or less: any acknowledgement of who initiated the peace process; attempts at previous peace talks; reasons why previous peace talks failed; how long negotiations at Camp David lasted; the 
fact that Israel returned the Sinai to Egypt; U.S. reaction to Camp David; and any unresolved issues not addressed by Camp David.

ALL DECADE SUMMARY: 1979 Camp David (See Appendix C p. 268 for chart)

\begin{tabular}{|c|c|c|c|c|c|c|c|}
\hline Publisher & $1950 \mathrm{~s}$ & $1960 \mathrm{~s}$ & $1970 \mathrm{~s}$ & $1980 \mathrm{~s}$ & $1990 \mathrm{~s}$ & $2000 \mathrm{~s}$ & Totals \\
\hline HM & $\mathrm{X}$ & $\mathrm{X}$ & $\mathrm{X}$ & $1(\mathrm{~N})$ & $2(\mathrm{P})$ & $2(\mathrm{~N})$ & $\mathbf{5}$ \\
\hline HOLT & $\mathrm{X}$ & $\mathrm{X}$ & $\mathrm{X}$ & $2(\mathrm{P})$ & $1(\mathrm{~N})$ & $1(\mathrm{~N})$ & $\mathbf{4}$ \\
\hline PH & $\mathrm{X}$ & $\mathrm{X}$ & $\mathrm{X}$ & $3(\mathrm{~N})$ & $3(\mathrm{~N})$ & $3(\mathrm{~N})$ & $\mathbf{9}$ \\
\hline
\end{tabular}

\section{Category of Analysis}

1980s Conflict in Lebanon: (See Appendix B pp. 240-249 for edition specific information)

\section{1. "What are the underlying problems which have generated this discourse" (Larsen, 1991)?}

Two texts (Holt 1986 and HM 1996) begin their discussion of the Middle East and Lebanon by providing context on Egypt-Israeli relations and include the fact that Sadat's successor, Hosni Mubarak, had much cooler relations with Israel and began reestablishing the ties with Arab nations that had been broken after Camp David. The same two texts (Holt 1986 and HM 1996) also cite Palestinian claims to Israeli land as an underlying source of conflict in the region. PH 86 and PH 95 both cite Lebanon's different groups of Christians and Muslims as the source of the conflict there, while the PH 2005 edition cites various "armed political groups, some backed by neighboring countries" as the underlying source of conflict in Lebanon (p. 1106).

\section{ALL DECADE SUMMARY:}




\section{What theories provide the descriptions and explanations thought relevant?}

With the exception of PH 2005, all of the texts' theories center on Israel attacking Lebanon in order to drive the PLO out of the country, although none mention how the PLO had come to be centered in Lebanon or why the PLO presence in Lebanon was even a problem for the Israelis. Theories regarding the presence of U.S. troops in Lebanon include guaranteeing the safety of the PLO as it pulled out of Lebanon (Holt 1986, HM 1996), restoring order (PH 1986), and keeping the peace in the region (PH 1995, PH 2005).

\section{ALL DECADE SUMMARY:}

\section{What relationships, causes, consequences are proposed?}

Earlier texts explicitly mention relations in the region, including cooled relations between Egypt and Israel (Holt 1986, HM 1996), the U.S. protest of Israeli action in Lebanon (Holt 1986, PH 1986), fighting between Christian and Muslim groups in Lebanon (Holt 1986, PH 1986), a continued Israeli presence in Lebanon (PH 1986), and increased Palestinian hostility toward Israel (HM 1996). The cause of Israel's invasion of Lebanon, if it is mentioned at all, is to clear PLO presence and bases from the region (Holt 1986, PH 1986). Only one text mentions that the civil war between Christians and Muslims in Lebanon resulted in Syria's invasion of the country (PH 1986). Consequences of the unrest in Lebanon, according to the texts, included an international and/or U.S. peacekeeping presence in Lebanon (Holt 1986, PH 1986, HM 1996, PH 2005), an attack on the U.S. marine barracks in Lebanon (Holt 1986, PH 1986, HM 1996, PH 1995, PH 2005), an attack on the U.S. embassy in Lebanon (Holt 1986, HM 1996, PH 1995), pulling American forces out of Lebanon (Holt 1986, PH 1986, HM 1996, PH 
1995, PH 2005), and ultimately, an unsuccessful attempt at establishing peace in the region (Holt 1986, PH 1986). Later texts tend to focus only on the removal of troops as a consequence instead of the unsuccessful attempt at establishing peace in the region.

\section{ALL DECADE SUMMARY:}

\section{On what premises is the account based and what assumptions are made in the course of the explanation (Larsen, 1991)?}

With the exception of PH 95 and PH 2005, all of the texts base their accounts on the premise that Israel was successful in driving the PLO out of Lebanon but unsuccessful in establishing peace in the region. HM 1996 even points out that antiIsraeli sentiments among the Palestinians were only increasing. While implicit assumptions vary from text to text, one found in all of the texts is that the terrorist attacks

on the American marine barracks and embassy in Beirut were responses to the American military presence in Lebanon. Since no attacks on Israel from southern Lebanon and carried out by the PLO are mentioned in the texts, a student could imply that the PLO, while centered in southern Lebanon, had not carried out any attacks on Israel prior to Israel's invasion of Lebanon. An example of this implicit assumption is found in Holt 86: "Israel was seeking to wipe out bases from which the PLO could make raids and to destroy its effectiveness" (emphasis added p. 936).

\section{ALL DECADE SUMMARY:}

\section{What perspectives, questions, theories are not acknowledged (Larsen, 1991)?}

It is interesting to note that PH 2005 is the first text not to mention Syria, the PLO, or Israel by name in its discussion of Lebanon; it is also the first text not to mention the bombings of the American embassy in Lebanon or that American forces were part of 
a larger UN peacekeeping effort. Other perspectives, questions, and theories left unacknowledged include no mention of Egypt-Israeli relations since Camp David (PH 1995 and PH 2005); why Egypt-Israeli relations cooled since Camp David (Holt 1986, PH 1986, HM 1996); how the PLO came to be centered in Lebanon (all five texts); who was in charge of the PLO (all five texts); the fact that Israel even invaded Lebanon (PH 1995 and PH 2005); divided Israeli opinion on the invasion of Lebanon (all five texts); U.S. opinion of Israel's actions in Lebanon (HM 1996, PH 1995, PH 2005); international opinion of Israel's actions in Lebanon (all five texts); why Syria invaded Lebanon (all texts except PH 1986); the tenuous political situation in Lebanon between Christian and Muslim groups (all five texts); why Israel and Syria involved themselves in Lebanese politics (all five texts); what terrorist organization was responsible for the Lebanon marine base bombing (all five texts) and the motivations of the responsible terrorist group (all five texts); and what actions, if any, the U.S. took to secure peace in Lebanon and negotiate with Israel (all five texts).

ALL DECADE SUMMARY: 1980s Lebanon (See Appendix C p. 269 for chart)

\begin{tabular}{|c|c|c|c|c|c|c|c|}
\hline Publisher & $1950 \mathrm{~s}$ & $1960 \mathrm{~s}$ & $1970 \mathrm{~s}$ & $1980 \mathrm{~s}$ & $1990 \mathrm{~s}$ & $2000 \mathrm{~s}$ & Totals \\
\hline HM & $\mathrm{X}$ & $\mathrm{X}$ & $\mathrm{X}$ & $\mathrm{X}$ & $2(\mathrm{~A})$ & $\mathrm{X}$ & $\mathbf{2}$ \\
\hline HOLT & $\mathrm{X}$ & $\mathrm{X}$ & $\mathrm{X}$ & $1(\mathrm{~A})$ & $\mathrm{X}$ & $\mathrm{X}$ & $\mathbf{1}$ \\
\hline PH & $\mathrm{X}$ & $\mathrm{X}$ & $\mathrm{X}$ & $2(\mathrm{P})$ & $1(\mathrm{P})$ & $1(\mathrm{~N})$ & $\mathbf{4}$ \\
\hline
\end{tabular}

\section{Category of Analysis}

1990s Peace Negotiations: (See Appendix B pp. 249-258 for edition specific information) 


\section{1. "What are the underlying problems which have generated this discourse"}

\section{(Larsen, 1991)?}

\section{ALL DECADE SUMMARY:}

None of the texts identify specific underlying problems regarding the Arab-Israeli conflict that lead to the peace agreement; the texts begin with the peace agreement and continue from there. Three texts imply that underlying problems were post-Cold War in nature, more regional conflicts rather than confrontations between superpowers, and the Arab-Israeli conflict was no exception to this pattern (HM 1996, Holt 1995, PH 2005). One text (PH 1995) is exceptionally detailed in its description of underlying problems, while one (Holt 2003) does not include any underlying problems that lead up to the peace agreement or influence it thereafter.

\section{What theories provide the descriptions and explanations thought relevant?}

\section{ALL DECADE SUMMARY:}

Each text was extremely different when it came to the theories that guided descriptions and explanations in the text. Since there was no discernable pattern, see Appendix B pp. 250-251 for the detailed theories found in each textbook.

\section{What relationships, causes, consequences are proposed?}

\section{ALL DECADE SUMMARY:}

Relationships in the majority of the texts consist of Rabin and Arafat signing the peace agreement and mention Clinton's involvement in some capacity (HM 1996, Holt 1995, Holt 2003). Without exception, there is a picture of Rabin and Arafat's handshake while Clinton looks on in approval. Interestingly, only two texts (both from the same publisher) hint at difficulties between Arafat and Rabin, one stating that it was a "prickly 
process" (PH 1995), and the other that "it was an extremely difficult step" for both leaders (PH 2005). PH 95 also includes the challenges to Arafat's authority from within the PLO and arguing between Arafat and Rabin over border crossing. PH 2005 includes a statement that Israeli Prime Minister Barak had "a greater commitment to peace talks," but his successor Sharon was "a fierce critic of the concessions Israel had made in the search for peace."

None of the texts include a cause for the 1993 peace agreement. One text (PH 1995) does imply that both sides' weariness in fighting over the Gaza Strip and West Bank could be a cause.

Regarding consequences, the majority of texts, especially later ones, present this as another missed opportunity for peace. Holt 95 and 05 clearly pin the blame for continued violence on Israel, while PH 95 and PH 05 make attempts to be more evenhanded. Two of the early texts (HM 1996, PH 1995) mention some Arab hostility toward Arafat for the agreement, and only one (HM 1996) mentions U.S. financial assistance to the PLO as a result of the peace agreement.

\section{On what premises is the account based and what assumptions are made in the course of the explanation (Larsen, 1991)?}

\section{ALL DECADE SUMMARY:}

The premise of each text was much the same, proposing that the 1993 peace agreements were a hopeful step forward in gaining stability in the Middle East. The texts do acknowledge that events following the peace agreement were setbacks in the process, but only PH 05 totally abandons hope, stating that peace "faded rapidly as violence increased again" (p. 1137). All of the texts imply that Arafat and Rabin signed the peace 
agreement themselves, when in fact, they did not. Other assumptions include that the Palestinians may have been cooperating only to gain financial assistance from the U.S. (HM 1996); the "other issues" of negotiations that were left for a later date might be easily worked out since a framework for peace was already begun (HM 1996); the only reason for violence following the peace accords was due to a Jewish gunman's attack on Muslim worshipers in the West Bank (Holt 1995); that both sides were weary of fighting over the Gaza Strip and West Bank and ready to make concessions (PH 1995); there were no outstanding issues of contention left after the 1993 peace accord (Holt 2003).

\section{What perspectives, questions, theories are not acknowledged (Larsen, 1991)?}

\section{ALL DECADE SUMMARY:}

The following topics are not included in any of the texts: historical context for the peace talks (particularly the end of the Cold War and how it resulted in the PLO losing its financial sponsor in the Soviet Union; the Persian Gulf War); the "Oslo Accord" or "Declaration of Principles" by name; Israel's agreement to limit further settlement in the West Bank; that Rabin and Arafat did not actually sign the agreement themselves; Jordan's motivations for negotiating a separate peace with Israel; or Palestinian division among the PLO, Fatah, and Hamas.

Only one out of the five texts mention the following: prior secret meetings between PLO and Israeli leaders (PH 1995); Israel's withdrawal of forces from Gaza and the West Bank (PH 1995); Palestinian responsibility for security in areas the Israeli Defense Force evacuated (HM 1996); Jordan's separate peace agreement with Israel (HM 1996). 
Two out of five texts mention the following: specific issues of contention left unresolved by the agreement (PH 1995, PH 2005); increased terrorist attacks against Israel after the signing (PH 1995, PH 2005); Rabin's assassination, who assassinated him, and why (Holt 2003, PH 2005).

A majority of the texts mention the following: the peace agreement's affirmation of a Palestinian right to self-government (HM 1996, Holt 2003, PH 2005); the PLO's formal recognition of Israel (PH 1995, Holt 2003, PH 2005); U.S. reaction to the peace agreement (HM 1996, Holt 1995, Holt 2003); Israeli reaction to the peace agreement (Holt 1995, PH 1995, PH 2005); Palestinian reaction to the agreement (HM 1996, PH 1995, PH 2005).

\section{ALL DECADE SUMMARY:}

1990s Peace Negotiations (See Appendix C p. 270 for chart)

\begin{tabular}{|c|c|c|c|c|c|c|c|}
\hline Publisher & $1950 \mathrm{~s}$ & $1960 \mathrm{~s}$ & $1970 \mathrm{~s}$ & $1980 \mathrm{~s}$ & $1990 \mathrm{~s}$ & $2000 \mathrm{~s}$ & Totals \\
\hline HM & $\mathrm{X}$ & $\mathrm{X}$ & $\mathrm{X}$ & $\mathrm{X}$ & $2(\mathrm{~N})$ & $\mathrm{X}$ & $\mathbf{2}$ \\
\hline HOLT & $\mathrm{X}$ & $\mathrm{X}$ & $\mathrm{X}$ & $\mathrm{X}$ & $1(\mathrm{~A})$ & $1(\mathrm{~A})$ & $\mathbf{2}$ \\
\hline PH & $\mathrm{X}$ & $\mathrm{X}$ & $\mathrm{X}$ & $\mathrm{X}$ & $3(\mathrm{~N})$ & $2(\mathrm{~N})$ & $\mathbf{5}$ \\
\hline
\end{tabular}

\section{$\underline{\text { Category of Analysis }}$}

Post 9/11: (See Appendix B pp. 258-261 for edition specific information)

\section{1. "What are the underlying problems which have generated this discourse"}

\section{(Larsen, 1991)?}

Because only two texts were analyzed for this category, it is difficult to make generalizations and identify patterns for all of the analysis questions. More specific 
information on each text can be found in Appendix B. The two texts identified conflict over the land itself (HM 2003) as well as Israeli Prime Minister Sharon's unwillingness to compromise (PH 2005) as the underlying problems for the continuing conflict.

\section{What theories provide the descriptions and explanations thought relevant?}

HM 03 identified Arab terrorist groups as being the chief cause of a continued lack of peace between Israel and the Palestinians, while PH 05 is more hopeful that the 2003 "roadmap" to peace may lead to a lasting solution.

\section{What relationships, causes, consequences are proposed?}

Relationships in the two texts included "widespread Arab anger" at Israel and the U.S. for its support of Israel, along with a continual cycle of violence between Israel and “terrorists" (HM 2003) and/or "Palestinian extremists" (PH 2005). The ultimate consequence in HM 03 was Israel's declaration of a “"war on terrorism,' patterned after the U.S. response to the September 11 attacks" (p. US8). In PH 05, the ultimate consequence was Israel's 2003 acceptance of the "roadmap to peace" that led to Israel first recognizing the Palestinians' right to a state.

\section{On what premises is the account based and what assumptions are made in the course of the explanation (Larsen, 1991)?}

The concluding premise of each text was that only time would tell if a lasting peace could be achieved between Israel and the Palestinians. Two implicit assumptions in HM 03 are that Palestinians would establish peace with Israel if terrorist organizations were not preventing them and that the only issue dividing the two sides is the land itself. PH 05 assumes that both sides approved the three-step roadmap to peace without reservations, establishing a Palestinian state in the West Bank and Gaza. 


\section{What perspectives, questions, theories are not acknowledged (Larsen, 1991)?}

The following perspectives, questions, and theories are left unacknowledged in one or both of the texts: specific terrorist groups in the Middle East or their various motivations for carrying out attacks against Israel; Israeli perspectives and feelings about terrorism; contention over security, borders, the right of return for Palestinian refugees, and the status of Jerusalem; contextual background information on the terrorist groups the texts identify (Palestine Islamic Jihad, Hamas, and Hezbollah) and the groups' terms for a Palestinian homeland; further U.S. interaction with Arafat, the PLO, and Israeli leaders following the 1993 peace accords; specific terms of the roadmap to peace, ensuing negotiations, and why both sides agreed.

\section{ALL DECADE SUMMARY: Post 9/11}

\begin{tabular}{|c|c|c|c|c|c|c|c|}
\hline Publisher & $1950 \mathrm{~s}$ & $1960 \mathrm{~s}$ & $1970 \mathrm{~s}$ & $1980 \mathrm{~s}$ & $1990 \mathrm{~s}$ & $2000 \mathrm{~s}$ & Totals \\
\hline HM & $\mathrm{X}$ & $\mathrm{X}$ & $\mathrm{X}$ & $\mathrm{X}$ & $\mathrm{X}$ & $3(\mathrm{~N})$ & $\mathbf{3}$ \\
\hline HOLT & $\mathrm{X}$ & $\mathrm{X}$ & $\mathrm{X}$ & $\mathrm{X}$ & $\mathrm{X}$ & $\mathrm{X}$ & $\mathbf{X}$ \\
\hline PH & $\mathrm{X}$ & $\mathrm{X}$ & $\mathrm{X}$ & $\mathrm{X}$ & $\mathrm{X}$ & $2(\mathrm{~A})$ & $\mathbf{2}$ \\
\hline
\end{tabular}

\section{Overall Summary of Research Findings}

Several patterns emerged when looking at the textbook data as a whole. When considering the number of neutral, pro-Israel, and anti-Israel textbooks over the decades, it became apparent that the number of neutral textbooks steadily increased with each decade. The neutral category was the most prevalent type of textbook in only half of the decades, however (1980s, 1990s, and 2000s). The 1950s was the only decade that contained more pro-Israel textbooks than any other category. The 1960s, 1970s, and 
2000s contained more anti-Israel than pro-Israel textbooks, and the 1980s were evenly tied at five textbooks each for pro-Israel and anti-Israel. Also, the 1960s and 1970s contained more anti-Israel textbooks than any other category.

While some publishers were rated better than others in various categories of analysis (see Appendix C), there was a clear leader. The one to three ratings on the quality and thoroughness of each publisher's Arab-Israeli content throughout the decades ranked Prentice Hall the highest with 53 points; Holt was a close second with 51 points; and Houghton Mifflin was a distant third with 33 points.

When examining counts for all categories of analysis and terms for each decade, the amount of information on the Arab-Israeli conflict in textbooks increases steadily through the 1990s then sharply declines in the 2000s. In fact, several categories of analysis saw their peak in the 1990s textbooks, including the mandate period, the 1948 war, the 1979 Camp David Accords, and the 1993 peace agreements. People and terms that peaked in the 1990s were David Ben-Gurion, Arab(s), Israel/Israeli, and Palestinian.

When considering all three publisher's totals for the individual categories of analysis, significant trends were observed. Information on the mandate period steadily increased (sharply in the 1980s and 1990s) then decreased in the 2000s, though remaining above 1980 levels. After taking a slight dip in the 1960s, information on the 1948 war steadily increased in all of the remaining decades. Information on the Suez Canal peaked in the 1960s and steadily declined thereafter. Information on the 1967 Six Day War peaked in the 1970s and steadily declined thereafter. Information on the 1973 Yom Kippur War peaked in the 1980s and declined to its lowest levels in the 2000s textbooks. Camp David information peaked in the 1990s and declined in the 2000s but remained 
above 1980 levels. Information on Lebanon was most prevalent in the 1980s and sharply declined to the lowest levels in the 2000s textbooks. Information on the 1993 peace agreements was highest in the 1990s textbooks and declined sharply thereafter.

When considering all three publishers' totals for the individual terms of analysis, several trends were observed. The only terms that steadily increased and reached their highest levels in the 2000s textbooks were Jew(s)/Jewish and Palestine (although Palestine did slightly dip during the 1970s). The term Arab rose sharply through the 1990s then sharply declined in the 2000s textbooks. The terms Israel/Israeli and Palestinian also steadily increased through the 1990s then sharply declined in the 2000s.

Loewen, in his book Lies My Teacher Told Me (2008), correctly points out that "to understand how textbooks in the 1930s presented the Civil War, we do not look at the history of the 1860s but at the society of the 1930s." This thesis has made a small, yet concerted effort to accomplish this task - first, to identify patterns and changes in the Arab-Israeli conflict over time, and secondly, to investigate possible reasons why those changes occurred. Because six decades of information are being considered, the complex political, social, and educational reasons why changes occurred in each decade and for each category of analysis are too numerous to include here; however, several factors relating to the causes of major patterns and changes of each decade are discussed in chapter five.

In general, one of the most frequently-neglected areas in the textbooks concerned reasons for why events happened in the Arab-Israeli conflict. The textbooks typically begin with simple, factual statements about the occurrence of some new conflict in the Middle East. An analysis of a number of studies by Kuhn (1992), as cited in Chambliss 
(1994), found that "particularly young and less well educated people cannot distinguish between a claim and its evidence." Perhaps this is why textbooks do not waste time explaining why things happened, only stating that the events occurred. Unfortunately, as Chambliss points out, "Readers with less expertise than the subjects...might construct text representations that are even more inaccurate."

Another important gap in the textbooks was the absence of inter-relationships and their explanations. One example is how significant the collapse of the Soviet Union was to the Palestine Liberation Organization (PLO), since it was the PLO's primary international sponsor. Of course, none of that is mentioned in the texts' description of the 1993 Oslo Accords - a detail that sheds significant light on the proceedings. Herz (1979) states: "General statements without a factual foundation are empty and unconvincing." Herz continues with a content analysis question: "Are readings provided that allow the reader to form a reasoned opinion?" Like Herz and his study of the Cold War in textbooks, the answer in relation to the Arab-Israeli conflict as presented in the textbooks for this thesis would be an emphatic, "No." Increased neutrality has left generic information in its wake; it would be impossible for a student to form a reasoned opinion of the Arab-Israeli conflict using textbook content alone.

Regarding the changing amount of information in the different categories of analysis (e.g., the overall decrease of information about the Six Day War, the overall increase in information about Israel's mandate period and 1948 War), Marty (1982) reasons, "In different times we ask different questions... Most frequently revisionism is a natural side effect of attempts to write contemporary history. If it is true, as Santayana said, that history always needs to be rewritten because it is always written wrong, the 
reason may be that it is written too soon." The intractable nature of the Arab-Israeli conflict and the continuous influx of new information mandate that publishers edit and shorten content. As Bragdon (1969), a former textbook author, states: "To shorten you must simplify, and you inevitably falsify, since history is never simple." 


\section{DISCUSSION AND IMPLICATIONS}

\section{The Historic Progression of History Education, the Social Studies, and Textbooks}

It is impossible to understand the place of history education, the social studies, and textbooks in secondary schools from the 1950s onward without first considering important events within the historical and educational community prior to this decade. One of the most notable events is the American Historical Association's (AHA) appointment of the Committee of Seven in 1899 "to consider the subject of history in the secondary schools and to draw up a scheme of college entrance requirements" (McLaughlin et al., 1899). Even though the professionalization of history in the U.S. began around this time and secondary schools were growing in number, the Committee of Seven only recommended a broad curricular framework of four years of historical study: ancient history; medieval and modern European history; English history; and U.S. history and government. The Committees' recommendations are considered to be the "birth of modern history education in the United States," firmly establishing history's core curricular position in the public schools (Orrill \& Shapiro, 2005). However, secondary teachers were left to fill in the specifics of curricular content, and because of this shortcoming, failure rates on college entrance examinations were higher in history than in any other subject (Wrobel, 2008).

Following World War I, widespread skepticism over humanity's progress and the growing popularity of the social sciences began to challenge history's centrality within the schools. Historians began using the pejorative term "educationists" to describe school administrators and teachers who advocated a "social studies" approach to the 
curriculum, organized around pressing social problems and the needs of society (Wrobel, 2008). David Snedden, a prominent educationist, believed the purpose of schooling was not intellectual development, but socializing students to function well in group life. Along with other educationists, Snedden sought control over teacher certification laws and legislature requirements; he was so successful that, beginning in the 1920s, “...required courses in education dominated teacher preparation in most states, with only minimal attention given to disciplinary knowledge and expertise" (Orrill, 2005). Results of this influence can be seen today in teacher certification programs that stress pedagogy over subject content. The May 1933 issue of the Bulletin of the American Association of University Professors addressed concerns about this shift in teacher preparation (Munro, 1933).

The formation of the National Council for the Social Studies (NCSS) in 1921 consolidated the educationists' approach to history education in the schools, and the changing titles of the AHA's journal for teachers signifies its retreat from the school curriculum debate, along with its waning influence: The History Teacher's Magazine (1909), The Historical Outlook (1918), The Social Studies (1934), Social Education (1937). In ceding its magazine, financially and editorially, to the NCSS, the AHA essentially "left school history to fend for itself" (Wrobel, 2008). $1950 s$

Typical textbooks of the 1950s focused on America's greatness. Publishers during this period were particularly concerned with avoiding criticism from the political right and ardent anti-Communists - criticisms that had cost them during the 1940s. Seen in a Cold War context, textbooks were meant to contribute to the overall goal of 
education in the 1950s: "to strengthen Americans' resolve to fight the Cold War and to identify each generation's technical and intellectual elite" (Moskowitz, 1988). Fitzgerald criticized textbooks of the 1950s for failing to show any kind of relationship between one event and another and a near absence of economic analysis (Fitzgerald, 1979).

Criticizing educational policymakers, Fitzgerald stated that they had "managed to put the reformist curriculum of the Progressive era to work for conservative purposes; they had created a utopia of the present" (1979). Fitzgerald also highlighted the publishers' loyalty oath that Texas required, illustrating the fear of experimentation in curriculum during this period (Fitzgerald, 1979). This decade saw the formation of the Committee on the Role of Education in American History. This conference of historians concluded that a lack of knowledge of educational history "affected adversely the planning of curricula, the formation of policy, and the administration of educational agencies in the present crisis of American education" (Cremin, 1988). Cold War rhetoric was sometimes used to save history education from the "educationists"; by the middle to end of the decade, a "back to basics" transmission model of education seemed to be winning out over the educationists' progressive, student-centered model. The Progressive Education Association disbanded in 1955, the same year that a White House Conference on Education highlighted problems within the schools - problems that required immediate attention after the 1957 Soviet launch of Sputnik (Ryan \& Townsend, 2010). The National Defense Education Act of 1958 began funding math, science, foreign language, and teacher training programs to resolve these problems (Gutek, 2000). Large suburban school districts also heralded new developments in American education (Gutek, 2000). 
$1960 s$

While the textbook publishing industry's sales were up to approximately 300 million dollars per year (Alexander, 1960) and the industry had been institutionalized for many years (Watt, 2007), the policy of "benign neglect" on the part of the AHA toward secondary history curriculum continued into the 1960s. This allowed social scientists, according to Link, to "[move] into the vacuum and [begin] to reorganize high school curricula" (1985). Indeed, a 1960 article in Social Education stated that history textbooks “...encourage little respect for the historian's craft" (Alexander, 1960). In the midst of the social and cultural upheaval of the 1960s and 1970s, Hertzberg summarized the approach of social scientists: "The new emphasis was both ahistorical and antihistorical. The past was relevant only when it dealt with matters of burning social or personal concern" (1980). Some educational reformers even viewed schools as an environment where the unequal distribution of resources in society could be equalized (Moskowitz, 1988). A student in the 1960s typically took one year of world history and one year of U.S. history (Wrobel, 2008). In her book America Revised, Fitzgerald stated that reading textbooks from the 1960s was a "bewildering experience," since she claims that changes made to the textbooks were changes "to nothing less than the character of the United States" (1979).

Many academics writing about changes that occurred in history textbook content trace those changes back to the 1960s when textbook publishers began to acknowledge the U.S. as a multicultural and multiracial society. As Barton Bernstein stated: “...The rediscovery of poverty and racism, the commitment to civil rights and the Negroes, the 
criticism of intervention in Cuba and Vietnam, shattered many of the assumptions of the fifties and compelled intellectuals to re-examine the American past" (Bernstein, 1968). The 1960s saw a massive influx of government funding to math and science programs throughout the country; of the 53 projects funded by the National Science Foundation (NSF) between 1956 and 1975, 43 were math and science programs, and 10 were social studies programs (Gutek, 2000). Attempting to balance the concentration of resources, the U.S. Office of Education (USOE) began Project English and Project Social Studies. Among the projects begun were "an analysis of public issues, an American history program for high school, history for able students, economics for elementary students, and geography, anthropology, and sociology programs" (Larsen, 1991). Also funded through the USOE were 12 university curriculum centers dealing specifically with social studies disciplines. Describing these curriculum efforts, Larsen states: "Generally, like most National Science Foundation curriculum efforts, the projects in the social studies were designed for the above average student and downplayed or omitted citizenship education, affective learning, social problems, and the relationships among the social sciences" (Larsen, 1990). Characteristics of reform efforts generally included less history and more social studies, a focus on broad concepts, emphasis on values, and the occasional use of in-depth topic studies during a survey course.

Despite all of this, wide-scale adoption of the new social studies approach was limited. More history content was seen by some as protection against communism, and publishers were very cautious about statements that could offend social, political, or religious groups (Alexander, 1960). Larsen (1990) cites public attitudes, teacher competence, and availability of materials as factors that discouraged adoption of many 
reform efforts. He states: "The demands for equity in society and for relevance in the schools did not square with the reformers' stress on academic disciplines... Once the pendulum swung to relevance and self-realization, the massive federal funding expired...A new role for students emerged, that of social activist instead of academic inquirer" (Larsen, 1990).

In writing about the changes that took place in historical writing between the 1960s and 1970s, Myron Marty compared two similar publications: the National Council for the Social Studies 1961 publication Interpreting and Teaching American History edited by William Cartwright and Richard Watson and the NCSS 1973 publication The Reinterpretation of American History and Culture by the same editors (Marty, 1982). After detailing how the 1961 publication of "standard essays on standard themes" shifted toward the 1973 publication of "changing fundamental assumptions of historians and society," Marty states: "To lay the two volumes side by side and compare their contents is a stunning experience" (1982). Such a radical shift in the boundaries of history meant that the writing, teaching, and learning of history could not remain unchanged. In his introduction to The Past Before Us: Contemporary Historical Writing in the United States, Kammen uses a 1968 quote by notable historian, Richard Hofstadter: "If there is a single way of characterizing what happened in our historical writing since the 1950s, it must be, I believe, the rediscovery of complexity in American history... a new awareness of the multiplicity of forces" (Kammen, 1980). While this "rediscovery" in historical scholarship began finding its way into textbooks, one textbook selection committee also began to notice other trends, one of which was the publishers' emphasis on visual appeal over content (Alexander, 1960). 
Culturally, living in the 1970s meant facing "economic crisis, rising cost of living, continuing social and political revolution, emerging militant radical groups fomenting terrorism against innocent members of the public, and unprecedented technological advances in communication and multifunction tools" (McKenzie, 2005). History textbooks of the 1970 s began elevating social studies above strictly historical content, and publishers released new textbooks to state-level adoption buyers like Texas and California (Broudy, 1975). According to Hertzberger, writing in Kammen's The Past Before Us, the new social studies were "typically ahistorical," as well as preoccupied with "the desire to include the social sciences and social issues [with a] distinct air of social betterment” (Kammen, 1980). Peloso’s 1972 article about writing U.S. history from a "third-world perspective" is an example of this approach. Defining third-world students as "those student groups whose concern for the study of history flows logically from the nature of their dissatisfaction with American society today," Peloso suggested that traditional history was no longer relevant and even detrimental to the psychology of third-world students since their experiences were so different from the "Anglo-Saxon version" of U.S. history (Peloso, 1972). Specifically referencing students of African origin, he states that third-world students cannot accept standard history texts because they are excluded from the story. Moskowitz (1988) summarized the shift toward social studies since the 1950s:

The untenability of the 1950s ideology of prosperity and the failures of the overly ambitious educational rehetoric of the 1960s led many educators in the 1970s to advocate curriculum improvement. In the texts this shift took the form of a new emphasis on cultural differences...textbook companies, with this new educational agenda and a host of ethnic and racial advocacy 
groups at their doors, published textbooks that reinterpreted American history.

Hertzberg traced the continual movement toward social studies over history back to the NEA's 1913 Committee on the Social Studies in the Secondary Schools. The committee defined social studies as "those whose subject matter relates directly to the organization and development of human society, and to man as a member of social groups" and its purpose as "the cultivation of good citizenship" (Kammen, 1980). In summarizing the 1970s social studies reforms, Hertzberg characterized the movement as having a "kaleidoscopic quality" and a "widespread mindlessness" (Kammen, 1980). Concluding his dissertation review of education reform movements of the 1960s and 1970s, Larsen states: "Mindlessness marred reforms in the sixties and seventies; curriculum leaders refused to consider classroom realities and historical precedent" (Larsen, 1990). He faulted the country's own historical amnesia for the "intense focus on the present, to the rise of the youth culture, to the retreat of historians from school concerns, and to the impact of the ahistorical social sciences" (Larsen, 1990). $1980 s$

In 1979, the New York Times reported on a 20-year decline in SAT scores, and in 1983, the National Commission on Excellence in Education released their report entitled A Nation at Risk. The report specifically emphasized textbook quality and recommended that textbooks be more rigorous, demanding, and diversified according to student abilities, giving attention to recent scholarly research (National Commission on Excellence in Education, 1983). A Nation at Risk prompted several inquiries into textbook quality during the 1980s, but interestingly enough, few government proposals resulted from the report. One author reasoned the lack of initiative was because the idea 
of local school control regained strength during this time, and the tendency of local control was to resist curriculum change (Larsen, 1990). Because of this resistance and a failure to define common curriculum, the textbook publishing industry "acquired a de facto role as a national curriculum authority" (Westbury, 1990). At the time of Anyon's 1979 study, analysts estimated that 40 publishing houses could produce a profitable textbook on a nationwide basis. The American Textbook Council released 1988 estimates of the top ten U.S. school publishers; all three textbook publishers used for this study appear on the list, with Harcourt (now Holt, Rinehart, Winston), Houghton Mifflin, and Pearson/Prentice Hall rated at numbers one, five, and nine, respectively (G. Sewall, 1992). According to Marty, writing history in the 1980s meant writing from the bottom up and using various research methods to "make moral judgments in the writing of history; to engage in national self-criticism rather than national chauvinism; to use oral interviews as ways of gathering information; and turning to non-literary sources for information about the past - artifacts, photographs, buildings, material culture, and the cultural landscape" (Marty, 1982). Shorter segments of history attempted to engage the students' interest, and many social studies skills from the 1960s were now incorporated into the text—-study skills, problem solving, reading graphs, and more (Dutton, 1989). While publishers' historic reluctance to avoid offending statements remained, some complained that the conservative tone of the 1950s had been abandoned for environmental, feminist, and liberal ideologies (Vitz, 1986). In his 1984 Presidential Address, the president of the AHA reignited questions from early in the century about social studies versus history education when he called for, according to Wrobel's summary, "closer ties between the history academy and the schools, greater interest in 
helping shape the school history curriculum, and greater assistance to school teachers in their efforts to come to grips with new scholarship" (Wrobel, 2008)

Another problem, cited specifically in Sewall's 1987 report on textbook quality, was overly broad coverage, resulting in "mentioning" of material rather than a cohesive narrative of the nation's past (G. Sewall, 1987). At the time of Frances Fitzgerald's publication in 1979, about half of the states had textbook approval/adoption lists from which textbook selection committees could choose (Metcalf \& Downey, 1980). $1990 s$

In 1993, 4 billion of the total 13 billion dollar domestic book market was spent on textbooks and other instructional materials. Foster (1999) postulates why the textbook industry is so attractive to publishers: “...Most textbooks have a print run of several million copies, are adopted for five- to seven-year cycles, require little marketing once adopted, and are exceedingly simple to distribute." At the beginning of the 1990s, the five largest companies, Macmillan; Harcourt, Brace, Jovanovich; Simon and Schuster; Scholastic; and Houghton Mifflin dominated 58\% of all national sales (Foster, 1999). In the midst of this vast market, a tension arose among curriculum experts about what constituted the right balance between Western and non-Western topics in history curriculum. According to Sewall, European political history alone was no longer sufficient, and a move to politicize historical content began among multicultural activists, scholars, and textbook editors (G. Sewall, 2003). Ravitch (2010) provides an excellent synopsis of the movements and challenges facing the field of history in the late 1980s and 1990s. Beginning in 1987 with California's history curriculum, the movement to revive history education continued into 1988 with the Bradley Commission on History in the 
Schools. Both sought to "counter the baneful effects of the social studies field, which [had] quietly driven history out of the lower grades and attempted to replace it in the high schools with courses about contemporary issues absent any historical grounding" (2010). Ravitch claims the ethnic activism of the early 1990s once again stalled movement toward history education over social studies. Attempts at defending history education in the early 1990s were most often denounced as "Eurocentric," with the 1994 publication of proposed national history standards fanning the flames of debate.

Initially, when history was identified as one of the five core curriculum areas in 1992, the Bush administration contracted the National Center for History in the Schools at the University of California at Los Angeles to develop national history standards for U.S. and world history. The voluntary standards were broken down into two categories: historical content (understanding) and historical process (thinking). In summarizing the standards, Foster stated: "On the one hand, therefore, the creators of the standards deserve praise for challenging existing practice and encouraging students to view history as a critical discipline rather than a mindless trivia game. On the other hand...teachers are offered little guidance on how they might introduce and structure students' historical thinking in meaningful and progressive ways" (Foster, 1999b).

In the introduction to his book Schoolbook Nation, Joseph Moreau cites a Gallup poll showning four out of five Americans supported the general concept of standards; however, agreeing on a general concept of standards was far different than agreeing on the standards themselves (Moreau, 2003). Moreau identified three opposing factions of the standards debate: "Cultural nationalists, conservatives, and a more heterogeneous 
group that defied a simple label but was defined mostly by its opposition to the first two camps" (Moreau, 2003).

The first group, cultural nationalists, found their champions in academics like E.D. Hirsch, an English professor at the University of Virginia, as well as Diane Ravitch and Arthur Schlesinger, Jr., two prominent historians. While all three had allied themselves in the debate, their motives were largely different: Hirsch was concerned with disadvantaged students' lack of access to elite knowledge and training; Ravitch with declining standards of intellectual rigor in pre-collegiate curriculum; and Schlesinger with the threat of national disintegration from the absence of a unified story of American history (Moreau, 2003). Hirsch believed that schools were failing to impart the "cultural literacy" to students that all Americans should know in order to communicate effectively with one another. This problem was compounded by the fact that most of the students not receiving this education were already poor and disadvantaged. Hirsch blamed Dewey and the educators who followed his belief that learning should be built around a child's interests and prior knowledge. While Hirsch believed this approach to education called "formalism" was valid to a point, he argued that it had been taken too far when educators assumed that curriculum did not matter because students would invariably develop necessary analytical skills despite the topic being studied. Blaming the same educational philosophy was Diane Ravitch, whose ire was provoked by the breakdown of history into the "pseudo-discipline" of social studies (Moreau, 2003). In the same vein of Hirsch's Cultural Literacy, Schlesinger published a book in 1991 entitled The Disuniting of America: Reflections on a Multicultural Society. Like Hirsch, Schlesinger achieved national popularity for his work. Moreau commented, "Where Hirsch's opponent had 
been an abstract theory, formalism, Schlesinger's enemies were flesh and blood. He offered an especially unflattering portrait of Afrocentrists...[and] was especially troubled by claims from some that young Blacks learned differently from Whites" (Moreau, 2003). In his book, Schlesinger warned:

The use of history as therapy means the corruption of history as history...Instead of a transformative nation with an identity all its own, America in this new light is seen as a preservation of diverse alien identities...The multiethnic dogma abandons historic purposes, replacing assimilations by fragmentation, integration by separatism. It belittles unum and glorifies pluribus (Schlesinger Jr., 1998).

While cultural nationalists argued for a cultural tradition for its own sake and because it was an inherited tradition, the second group in the standards debate, conservatives, went further:

They argued not only that the heritage of the West formed the core of American identity but that it was superior to its rivals abroad and to the intellectual mélange offered by multiculturalists, deconstructionists, feminists, and others of that ilk at home. Their vision of the nation's past, and of the way it had been taught until the 1960s was warmly sentimental" (Moreau, 2003).

Conservative champions were Allan Bloom, who wrote The Closing of the American Mind, and Newt Gringich, who wrote To Renew America. For Gingrich, the 1960s were to blame, and Democrats like Bill Clinton reflected the moral void left in its wake. "Thus even before the standards appeared, history teaching was becoming a proxy in a broader cultural and political war" (Moreau, 2003).

While Moreau attempts to label the third group "progressives" or "radical multiculturalists," he admits the names fail to express the group's lack of ideological unity. What did unite them was their less than sentimental feelings for "traditional" 
history and a distrust of those who supported it, along with "open hostility to conservatives like Gingrich" (Moreau, 2003). Included in this third group were educators who employed the social-studies-over-history approach to teaching and learning; professional historians who, in the years since the 1960s, had created specialized fields of historical research; and political "pressure groups" who felt these specialized research fields ought also to be included in national curriculum standards. A prominent spokesperson for this group was Gary Nash who wrote Red, White, and Black: The Peoples of Early America. To make their point, these radical multiculturalists often exaggerated the lack of historical research before the 1960s and the profusion of it afterward. The thesis of Frances Fitzgerald's 1979 book America Revised was perfectly suited for their platform.

The struggle over a politicized history was not new, as many contended in the 1990s. Early struggles over content in the history curriculum date back to the years following the Civil War and will be discussed later, as related to the textbook publishing industry in the U.S. However, according to Ravitch, as a result of this contention, educators "became convinced that it was better to stick with contentless 'social studies' than to risk a struggle over whose history should be taught" (Ravitch, 2010). $2000 s$

Taking into consideration that America's high school dropout rate remains between 5\% and 9\% (Hoyle \& Collier, 2006) (Haycock \& Huang, 2001) and graduation rates remain approximately the same in comparison to the 1970s (Haycock \& Huang, 2001), Wehling (2007) offers an unflattering portrait of America's educational system today: 
"Our current educational system is designed to produce a million or more dropouts per year; high school graduates with inadequate knowledge or skills for further education or the workforce; and education opportunities that are closely linked to the wealth and education of a child's parents and community...it is inconceivable that 16,000 school districts and 50 states will all wake up tomorrow and agree to enact what we all know as best practices."

Incensed that our nation's educational system was not listed as an important issue in 2008 election polling data while other nations consider it a top national priority and having one million dropouts per year continue to be tolerated by the American public, politicians, and news media, Wehling wrote his report in hopes of raising awareness and positing a solution. A national system of education, complete with national standards, curriculum, testing, teacher training, and funding that is independent of local communities' wealth summarizes his solution. According to Jackson (2008), the $21^{\text {st }}$ century also brings two specific challenges: "Two intertwined imperatives face U.S. education today. The first is addressing the problem of persistent underachievement...the second is preparing students for work and civic roles in a globalized environment, where success increasingly requires the ability to compete, connect, and cooperate on an international scale." According to the U.S. Census Bureau (2004), one in five U.S. jobs is tied to international trade. A 2009 report by the U.S. Chamber of Commerce, the Center for American Progress, and Frederick Hess of the American Enterprise Institute entitled "Leaders and Laggards: A State by State Report Card on Educational Innovation" echoed the current lack of preparation and the need to prepare students for the modern workplace. The overview of the report encourages "purposeful" and "far-reaching" innovation while praising independent ventures like Citizen Schools and Teach for America; it recognizes, however, that the nation's 100,000 schools and 3.2 million teachers are in dire need of 
reform (Hess \& Stoddard, 2007). While the report's methodology and findings are too comprehensive to summarize here, the overview includes an interesting comparison of America's schools to recent economic troubles:

In many respects the recent troubles of the auto and newspaper industries provide a cautionary tale for today's education policymakers. Analysts predicted structural challenges in both industries for decades. Outside consultants urged major change. Yet altering entrenched practices at businesses from General Motors to the now-defunct Rocky Mountain News proved enormously difficult. And the results of inaction for both organizations were disastrous. The same must not happen to our nation's education system. The stakes are just too high (Hess, 2009).

Beginning in 2002, this emphasis on the work place and civic engagement compelled the Partnership for $21^{\text {st }}$ Century Skills (now referred to as P21) to begin collaborating with educators, civic and community groups, and business leaders to build a framework for incorporating $21^{\text {st }}$ century skills into already existing curriculum (Johnson, 2009). In July of 2008, after two years of collaboration between educators and business leaders, the NCSS in cooperation with P21 released a $21^{\text {st }}$ Century Skills and Social Studies Map, which "provides educators with examples of how $21^{\text {st }}$ century skills can be integrated into classroom instruction and which highlights the critical connections between social studies and the $21^{\text {st }}$ century skills" (Russell, 2010). The map can be downloaded at www.p21.org/documents/ss_map_11_12_08.pdf; it identifies 12 desired skills and their related activities for fourth, eighth, and twelfth grades, along with intended outcomes and teaching ideas, each promoting civic, financial, or global literacy (Schachter, 2009). Although P21 has the backing of corporations like Adobe Systems, Apple, Dell, Hewlett-Packard, Microsoft, and Verizon, it has critics. Senechal (2010), writing for American Educator, disagrees with P21's assumption that schools' primary 
objective is to meet current workplace demands and calls P21's demands for less formal, explicit instruction and more immediate, useful, and hands-on instruction reminiscent of progressive ideas over the past 100 years. Senechal (2010) and other critics of reform efforts like P21 point out that the broad concepts and skills of critical thinking, problem solving, creativity, and innovation cannot occur before students have a core of foundational knowledge. Ravitch (2010) sees P21 as yet another initiative in a long line of initiatives beginning in the early 1900s that has left "American education with a deeply ingrained suspicion of academic studies and subject matter. 'It's academic' came to mean 'it's purely theoretical and unreal."' Citing efforts to "generalize and expand subjects beyond their disciplinary base - for instance, by replacing history with social studies," critics call for more focused study and practice of core content knowledge, much of which cannot be learned only by hands on activities.

Reformers forget, for instance, that knowledge enhances the very learning process in a number of ways, as Daniel T. Willingham (Willingham, 2010) and other cognitive scientists have found. They forget that fluency in the fundamentals allows students to engage in inquiry. They forget that content is not simply dry matter; it has shape and meaning; it is the result of centuries of critical thought and the basis for future critical thought. To neglect to teach our intellectual and cultural traditions is to limit the kind of thinking that students will be able to do throughout their lives (Senechal, 2010).

In relation to the broad concerns and suggested reforms of $21^{\text {st }}$ century education, the culture wars and concerns over history and social studies education in the 1980s and 1990s resulted in the September 2002 announcement of three initiatives led by the U.S. Department of Education as well as the "Teaching American History" (TAH) initiative. In his introductory remarks announcing the initiatives, President Bush stated:

Our Founders believed the study of history and citizenship should be at the core of every American's education. Yet today, our children have large 
and disturbing gaps in their knowledge of history. Recent studies tell us that nearly one in five high school seniors think that Germany was an ally of the United States in World War II. Twenty-eight percent of eighth graders do not know the reasons why the Civil War was fought. One-third of fourth graders do not know what it means to "pledge allegiance to the flag.' Graduating seniors at some of our leading colleges and universities cannot correctly identify words from the Gettysburg Address or do not know that James Madison is the father of the Constitution (Bush, 2002).

According to Wrobel, this infusion of tens of millions of dollars and emphasis on “traditional American history" has handed university and K-12 historians "a financial lifeline to together pull themselves out of the mire of their separate spheres" (2008). Indeed, Brysiewicz (2003), a high school history teacher who attended a two-week summer institute funded by the TAH initiative, stated: "If professors want their students armed with the tools to 'do history,' they need to spend some time in the trenches, learning how best to bring the historian's craft to the highly regimented environment of high school."

Concerning the state of history education versus social studies, in writing her book, The Language Police, Diane Ravitch reviewed 49 states' history standards and found that "history is making a comeback" (Ravitch, 2003). In 1994, only 4 states (California, Virginia, Mississippi, and Texas) had adopted history standards compared to 14 states in 2002 with "strong" history standards and 10 states with "reasonably good" standards, in Ravitch's opinion.

As of 2003, there were approximately 45 million public school students in the U.S., and "el-hi" textbook sales was a 4 billion dollar industry (G. Sewall, 2003). Sewall points out that, during this decade, textbook editors became even more sensitive to potentially-controversial subjects. In his words, "Textbooks pare to a minimum such touchy subjects as Israel and oil as agents of change in the Middle East since 
$1945 \ldots$ textbooks talk about 'fighting' in a neutral way" (G. Sewall, 2008). It is also relevant for the present study to note that according to Keith (2005), a former overseas diplomatic officer for the U.S., after 9/11, virtually all Muslims, including those outside the Arab world, came to reject what they regarded as "America's biased support for Israel” (Keith, 2005).

The intent of this study was to see, at least as far as high school history textbooks are concerned (and through the lens of the Arab-Israeli conflict), if there was support for all of these generational patterns and changes in American education.

\section{History of the Textbook Publishing Industry and Process}

After considering the historic progression of American education in general and history education in particular, the historical context for the present study would not be complete without a look into the textbook publishing industry. Textbook publishers today face a unique challenge because, in Ogawa's words, "The United States houses the most diverse ethnic, cultural, and linguistic school population in the world" (Ogawa, 2004). Even so, fewer textbook publishers mean fewer chances for the inclusion of these diverse backgrounds (Spring, 2000). In preparing to publish a textbook today, publishers begin with gathering information from a variety of organizations. These organizations are discipline-oriented (e.g., the National Council for the Social Studies) and can include state and national education agencies as well as particular "pressure groups" that seek to influence curriculum on their behalf (Garcia, 1993). Those that contend these groups have too much influence on textbooks should also take into consideration that the processes of textbook production and selection actually work against it, with the high financial stakes for publishers and school districts working as a check-and-balance 
system against change. Initial research and development costs for a history textbook series can exceed $\$ 500,000$ - a venture not undertaken lightly by publishers (Foster, 1999). The limited selection system that many states have can operate as a powerful economic weapon against publishers. The increasing use of multimedia resources by teachers and students, in and out of the classroom, has also diminished - though certainly not eliminated - the place of the textbook (Podeh, 2000).

Textbook publisher consolidation began in the 1890s, when three prominent textbook companies merged to create the American Book Company; the company very quickly gained dominance over 75 to 80 percent of the textbook market (Siler, 1987). The process of textbook adoption began around this time as well, shortly after the Civil War. Distrustful ex-Confederates established textbook committees to ensure that books with anti-Confederate sentiments were excluded from Southern schools (Ravitch, 2004). Publishers, headquartered in the North, acquiesced to Southern demands and began publishing separate textbooks. At the time of Ravitch's 2004 publication, most adoption states were still in the South and West, with California, Texas, and Florida dominating the market.

As early as 1960, an article in Social Education acknowledged that "copyright recency" was an important consideration on the part of publishers, and yet there was no guarantee for teachers that textbooks were current (Alexander, 1960). Ravitch's assessment of the work of editors today is especially critical:

To produce history textbooks, teams of writers and editors have mastered the art of compression, reducing complex controversies to a few lines or a page, smoothing out the rough edges of reality, eliminating the confusion and rancor that invariably accompanied major crises. Historical debates disappear or shrink to a few leaden sentences. Historical conflicts lose their drama, and the ideas of passionate individuals shrivel to simple 
platitudes. When history is compacted as severely as space requires, with the life squeezed out of it, the predigested pap that is left is not memorable, does not establish a foundation for future learning, and is guaranteed not to inspire in young people a sense of excitement about the past (Ravitch, 2003).

While editors may not intentionally be trying to kill history along with students' enthusiasm for it, the reality is that their work is produced in an industrial and capitalist environment. While Perlumutter (1997) recognized editors as "hard working, well-paid, respected, and talented professionals, with artistic or English backgrounds," he also noted that "Aesthetic considerations are more important than critical questions of educational value; pretty takes precedence over thought provoking” (Perlmutter, 1997).

Textbook authors also face problems and criticisms. In Watt's (2007) research of the textbook publishing industry, he found that as early as the 1950s, writing required collaboration between the authors, editors, and publishers, with most attention given to production techniques rather than authorship and content. By the 1960s, Watt states: "The authors of textbooks...offered the endorsement of authorship to the product rather than their contribution to the writing process" (2007). Bragdon, who helped author a popular American history textbook series over a 20-year period, wrote of his concerns about the process in an article for Social Education (1969). Watt (2007) summarized his findings:

Bragdon became concerned by two issues as development of the textbook proceeded. First, the organization of the content in the textbooks to facilitate its use for memorizing and regurgitating facts was not overcome...second, concerns to reduce the length of the text led to simplifications, the lack of comprehensive knowledge of the subject matter led to plagiarism, and the requirement not to offend different pressure groups led to the omission of controversial issues. Bragdon concluded that writing a textbook involved a requirement to make compromises in the interest of commercial success (2007). 
Textbook authors, most often professional educators and/or historians, also face criticism from their own professional community. Bierstadt (1955) recognized that financial benefit, rather than professional advancement and prestige, was the primary motivating factor for textbook authors. Broudy (1975) found that publishers sometimes paid authors who lent professional credibility but little in actual writing a higher royalty. Sewall summarized this continued practice into the 1990s:

The major incentive for skilled children's writers or history professors to contribute to school texts is a financial one. What serious writer for children or adults would be willing to submit to readability formulas and other indignities beyond authorial control? The writing of core text...is completed by anonymous writers in development houses and production companies: these are subcontractors laboring under the direction of a text editor (1994).

Loewen (2008), in writing about textbook authors, stated: "The first thing editors do when recruiting new authors is to send them a half-dozen examples of the competition... When historians do write textbooks, they risk snickers from their colleagues - tinged with envy, but snickers nonetheless: 'Why are you devoting time to pedagogy rather than original research?'" Even amid this kind of criticism, Bragdon (1969), coauthor of the nationally popular History of a Free People, wrote: "I found writing a textbook the most difficult form of composition I have ever attempted." No author, he acknowledged, could be expected to know everything about what needed to be included in a single volume of U.S. history. Along with a textbook author's reliance on secondary sources came this admission, albeit regretfully: "To shorten, you must simplify, and you inevitably falsify, since history is never simple” (Bragdon, 1969).

Big changes in the next few years may be in store for the multibillion dollar textbook industry in the U.S. An April 2010 article in Education Week detailed two 
measures passed by Texas lawmakers in 2009 that would allow state textbook aid to be used to purchase digital textbooks and gain access to open-source textbooks, which are available free on the Internet (Robelen, 2010). These measures preceded Texas governor Rick Perry's remarks in April 2010 that he wants Texas to move toward solely using digital textbooks. Considering this and California governor Arnold Schwarzenegger's initiative to provide digital textbooks in math and science for California high schools, publishers will be adapting to these new demands for years to come. Even if the influence of Texas and California is sometimes exaggerated as publishers like to claim, they are the two leading markets among the 20 "adoption" states in the U.S. The move toward electronic resources, coupled with various states' concerns about the growing expense of textbooks, could open the door for more local control of curriculum selection, along with an expansion of niche publishers who cannot currently compete with the development costs typically spent by the three largest publishing companies, Pearson, McGraw-Hill, and Houghton Mifflin (Robelen, 2010).

\section{Textbook Publishing Industry and Process Conclusion}

So how does one account for all of the changes in history and social studies teaching, textbook writing, and publishing since the 1950s? History teaches that effects rarely have one cause. It is clear that the tensions of the 1950s within the educational community between pedagogical methods of "essentialist transmission and progressive facilitation" and educational goals of intellectual development versus social behavior continue today (Ryan, 2010). Mehta, who studied educational reform movements throughout American history, found a common theme in each movement: education was always defined as "under-performing, inefficient, and unable to meet the challenges of a 
changing society" (Mehta, 2006). In every case - the 1910s, 1920s, 1960s, and today reformers sought to win public support by pledging to shift power upwards within the educational system: the historic progression was first to superintendents, then to states, and finally to the federal government (Mehta, 2006).

While history education may be making a comeback, one author's simple but profound observation that "no other national community of historians [and student body] is so inherently international," partially explains why social studies is not ceding its place in the curriculum either (Graser, 2009). A quick look at each decade reveals a pendulum swinging between the two. One author also likened curriculum reform efforts throughout the decades to perpendicular axes, with the vertical representing "excellence and heightened achievement" and the horizontal "toward equity and social justice" (Jackson, 1983). No matter which direction the pendulum is swinging or to which axis the reform has moved, it is always tempting to blame textbooks or to view them as a silver bullet for a quick solution.

\section{Generational Patterns Regarding the Arab-Israeli Conflict in the Textbooks}

Specifically addressing patterns and changes in the Arab-Israeli conflict by decade, and referring back to the summaries of each decade, the 1950s' focus on the status quo and publishers' particular concern with not offending the political right may explain why the 1950 s is the only decade with no anti-Israel texts. The 1960 s' focus on revision, relevancy, broad concepts, and visual appeal in textbooks may explain why there is such a dramatic increase in anti-Israel textbooks and decrease in specific information regarding the 1948 war. Suez Canal Crisis coverage was highest in the 1960s since it held the possibility for the first major conflict of the Cold War and was 
therefore considered to be very relevant. The 1970s' focus on social betterment, cultural differences, and more ahistorical content is reflected in the decrease in information on the Suez Canal, continued increase in both pro- and anti-Israel textbooks, and dramatic increases in uses of the terms Arab(s), Jew/Jewish, and Israel. The 1970s is also the first decade in which the term Palestinian is used in a textbook. The 1980s saw shorter textbook accounts with less conservative and more "bottom up" interpretations of content. This is reflected in continued increases in the terms Arab(s), Jew/Jewish, Israel, Palestine and Palestinian. Information on the 1948 war increased, while Suez crisis information decreased considerably in the 1980s. Information about the 1973 Yom Kippur War was at a dramatic all-time high in the 1980s, possibly because Americans were realizing the rising importance of foreign oil and the Middle East to the domestic economy. Information on the fighting in Lebanon is also most prevalent in the 1980s textbooks, only to decrease to its lowest point in the 2000s. In the textbooks, Lebanon was often overshadowed by the Iran hostage crisis and other concerns during Reagan's presidency. While it could be argued if the 1990s debate (between those supporting a multicultural/social studies approach in the classroom and those supporting core/historical content) produced better content, it can certainly be said regarding the Arab-Israeli conflict, that it produced more content. Indeed, the total amount of information on the Arab-Israeli conflict was highest in the 1990s. Several categories also continued rising and/or peaked in the 1990s, including the mandate period, the 1948 war, Camp David, 1993 peace agreements, and the terms Arab, Jew/Jewish, Israel, Palestine, and Palestinian. Educational trends in the 2000s emphasized the work place and promoting civic, financial, and global literacy, and in many ways, generic or non- 
discipline-specific academic skills. Then came 9/11 and publishers' heightened sensitivity for controversial subjects. Together, these factors created the perfect combination for a decrease in specific information on the Arab-Israeli conflict, which is what happened in the textbooks. The total amount of information on the Arab-Israeli conflict returned to 1980 levels and several individual categories decreased, including the mandate period, Suez Canal, 1967 war, 1973 war, 1979 Camp David, Lebanon, 1993 peace agreements, and the terms Arab (dropping dramatically to below 1970 levels), Israel, and Palestinian.

As previously stated, there could be many more political, social, and educational causes for the patterns and changes noted above; however, this thesis has attempted to identify the most significant factors. These, along with the specific changes to each category of analysis over time as summarized in chapter four, would not be helpful without also considering some of the general curricular and classroom implications of these patterns and changes.

\section{Conclusions and Recommendations}

On a systemic level, Ravitch and the Fordham Institute (2004) make a compelling case to abolish statewide textbook adoption:

This archaic and dysfunctional arrangement persists rather because of its accustomed familiarity and the instituational self-interests of publishers, political pressure groups, and the state educational departments in California and Texas, all of which have reached a mutual accommodation at the expense of the nation's schoolchildren...Eliminating statewide textbook adoption would make adoption states like open territory states, and would refashion the current $\mathrm{K}-12$ textbooks procurement system to make it operate more like a healthy market —one with competition among publishers, and incentives to produce quality textbooks that work. 
Since this is an unlikely solution, especially for the immediate future, preparation programs should teach future educators to recognize the limitations of textbooks and to use them as a resource. Lindaman and Ward (2004) explain:

In order to meet the market's demands, [textbook publishers] are doing away with what is most interesting about history: perspective, interpretation, historiography, bias, debate, and controversy. By reducing history to a set of inoffensive facts and figures, no matter how attractively packaged, book publishers are effectively judging students incapable of dissecting and debating important topics and issues.

When considering the omissions, oversights, bias, and misinformation regarding the Arab-Israeli conflict (and other topics) in high school U.S. history textbooks, one encouraging viewpoint is that the textbooks do not "force" bad teaching (Bragdon, 1969).

Teachers and students can $d o$ something about textbook shortcomings unlike so many of the systemic and social problems that schools and students face today. Teachers would do well to adopt Marty's (1982) opinion of textbooks:

My evaluations of textbooks are tempered by my low expectations as to what they can and should do in the teaching-learning process and my reluctant admission that I see little prospects for drastic improvement in the quality of the books. My low expectations make me tolerant, though not indifferent, to their shortcomings. My pessimism leads me to urge that teachers focus their efforts on something they can control, that is, the way textbooks are used. I believe that textbooks should function primarily as reference books; beyond this they can give a course a framework for study and students a sense of continuity.... as works of literature offering coherent accounts of the American past—well, that is too much to expect.

Romanowski (2009) also has several recommendations for how teachers can approach and overcome textbook omissions. Like Marty (1982), he states that textbooks should not be the final authority for the teacher or the students on a particular topic. 
Unless students have had no prior exposure to information about the Arab-Israeli conflict, it can be a controversial and emotionally-charged topic. Of course, most history teachers would extol the virtues of examining both sides of a conflict, but Pingel (2008) reminds readers of the oft-neglected practice of questioning one's own preconceptions. In his article, he compares various methods of teaching reconciliation through history and warns of the "didactic trap" for teachers and students in simply comparing two versions of one event: “...They [teachers] neglect the challenge of the blank space: they train their students to confront views and conduct a controversial debate that may strengthen extreme positions but that does not necessarily help them engage in a process of critical self-reflection and revision of preconceived opinions." As a class, simply listing student opinions of the Arab-Israeli conflict and periodically revisiting the list could be a useful evaluative tool. By referring back to the list as they learn more about the conflict, students can track their own learning progress and evaluate how and why their perspectives change along the way. Hahn and Tocci (1990) studied the relationship between classroom climate and controversial issues. Their introduction states:

"Researchers have consistently found that school instruction has little effect on the development of political attitudes and value orientations...[however] instruction can influence political attitudes under particular conditions." The article and the number of cited studies are too vast to summarize here; however, the crux of Hahn and Tocci's argument and the most pertinent point regarding controversial issues in the classroom is this:

"Attention to controversial issues is not sufficient to produce positive civic attitudes in students - at least as regards political efficacy and perhaps cynicism/trust; an open supportive classroom climate in which the issues are discussed seems to be a necessary condition...students who perceived 
their classes to be "high participatory," reported higher levels of political efficacy and interest and lower levels of trust than did students in "low participatory" classes. Additionally, those students who perceived their classrooms to be more participatory exhibited higher levels of support for rights guaranteed in the Bill of Rights."

So prompting students to explore controversial public issues and adopt more active roles in the classroom and community means not only focusing on the issues but also on the classroom environment in which those issues are addressed. Essentially, Hahn and Tocci, along with the many other cited studies found that "an open classroom climate was related to increases in political interest and political confidence" (1990).

Secondly, Romanowski (2009) notes it is the teachers' responsibility to provide students with the means to investigate differing perspectives of a historical event. In an effort to be neutral and unbiased, many of the textbooks in this study excluded Arab, Israeli, and American perspectives and reactions to major events in the Arab-Israeli conflict. Students are left to wonder why something happened and what happened next or adopt the impression that the conflict was resolved. Textbooks stifled the meaning by "suppressing causation" (Loewen, 2008). It is essential that students understand why events occurred, different points of view, and unresolved issues concerning the ArabIsraeli conflict. For example, Wade (1993) cites a study by Beck (1989) in which students who also read from revised versions of textbooks "understood why events occurred, and saw connections between events more often than students who read the original text version." Is it important to understand that students do not naturally compare sources or question why something happened. A study by Wineburg (1991) on how historians and students analyzed eight written and three pictorial documents on the Battle of Lexington found, "In contrast to the historians, the high school students failed to 
compare the documents, neglecting to recycle back through them to check for consistency in facts and reliability of the sources. They decided a textbook treatment...was the most trustworthy and chose pictures based on artistic merit rather than consistency with written documents." A simple, but profound step in teaching students how to think like historians would be to read a textbook account then list the perspectives, questions, and theories left unacknowledged in the text. Because one must know the content before being able to identify what has been left out, some of the responsibility for content knowledge lies with the teacher. However, a high school student should be able to identify the two most typical gaps in history textbook accounts - causation and consequences.

In order to make connections with the meaning and importance of a historical topic, Tunnell (1993) also suggests the use of historical trade literature in the history classroom: "When facts are an integral part of a compelling story, they are much more interesting and of more immediate consequence to a young reader than when presented in lists and pseudo-prose collections, as in a textbook." Because there are a plethora of resources on the Middle East, the use of historical trade literature lends itself well to the Arab-Israeli conflict.

Thirdly, Romanowski suggests using primary documents and writing assignments "that give students the opportunities to go through the same process of selections as textbook authors." For example, when dealing with the territories acquired by Israel in 1967, students could read UN Resolution 242 and compare secondary source information on Arab and Israeli perspectives of how the document justifies Israel's right to keep the territories for Israelis and proves 
Israel's illegal occupation of the territories for Arabs. In many respects, students, like textbook authors and editors, are just as dependent on secondary sources of information. Teaching students how to identify and utilize reliable sources of information is an essential skill, particularly regarding the Arab-Israeli conflict.

Lastly, Romanowski (2009) reminds teachers of pictures' power to encourage critical thinking. Studying the Arab-Israeli conflict, students could question why the textbook editors chose to include a particular photo, what important information the photo reveals that the textbook content does not, and write down questions that the photo leaves unanswered. Masur (1998) shares some unique perspectives on using images in the classroom, along with this caution:

We must remind our students that images reproduced in books carry limitations: we cannot see the brush strokes or the texture; we cannot discern the quality of the print; and when we see the pictures in color, the tones are not true. Further, the locations of seeing are as revealing as what is seen. We are unable to hold the magazine or newspapers, happen upon the broadside or poster, or visit the printshop or gallery of earlier times.

Images of the Arab-Israeli conflict have been a powerful tool in wielding international opinions and policy - a fact that students must be aware of. While images of the conflict are typically very emotionally charged, students must be reminded to evaluate images in light of factual information as well. Because the Arab-Israeli conflict is ongoing, it lends itself to learning from current events and a variety of media outlets for up-to-date information.

Romanowski includes the reminder that reasons for textbook omissions are "complex, and the 'true' motives for the exclusion of content could be debated"; however, textbooks should no longer be seen as just information to get through but as 
content that needs to be "questioned, analyzed, and negotiated" (2009). In this way, Loewen (2009) states that students will become "independent learners who can sift through arguments and evidence and make reasoned judgments... and neither a one-sided textbook nor a one-sided critique of textbooks will be able to confuse [them]."

Future teachers and those already in the classroom should remember that there are reliable, interesting, and challenging supplemental materials on most any historical topic; it simply takes time, effort, and research to find them. University centers for Middle Eastern studies are a good resource for grade-appropriate lists of references, curriculum guides, kits, and supplemental materials on the Arab-Israeli conflict and are available at little or no cost to schools. Although it does not include events after the 1973 Yom Kippur War, William Griswold (1975) has an exemplary unit of four major Arab-Israeli wars, created for secondary school classes and complete with "knowledge and comprehension goals" for each war. Rock's (1996) thesis, The Arab-Israeli conflict as depicted in children's and young adult non-fiction literature, is also a very comprehensive list of resources available for classroom use.

In their efforts to defend history's educational value, the early professional historians known as "the Seven" answered that the study of history produced what they called "historical mindedness" - an attentiveness to cause and effect that is "both humanizing in its outlook and essential to the intelligent exercise of civic responsibility" (Orrill, 2005). Teachers must remember that learning well is discipline specific, and as Wineburg (2003) states: "There is no such thing as generic critical thinking." Avoiding the controversy of the Arab-Israeli conflict, or teaching it solely as presented in a textbook, robs students and teachers of an opportunity to challenge their preconceptions 
and engage in an academic exercise that will develop discipline-specific critical thinking skills that can translate into real-world application. 


\section{References}

Alexander, A. (1960). The gray flannel cover on american history textbooks. Social Education, 24(11)

Al-Haj, M. (2005). National ethos, multicultural education, and the new history textbooks in Israel. Curriculum Inquiry, 35(1), 47-71.

Alridge, D. P. (2006). The limits of master narratives in history textbooks: An analysis of representations of Martin Luther King, Jr. Teachers College Record, 108(4), 662.

Anyon, J. (1982). Adequate social science, curriculum investigations, and theory. Theory into Practice, 21(1), 34.

Apple, M., \& Christian-Smith, L. (1991). The politics of the textbook. New York: Routledge.

Appleby, J., Hunt, L., \& Jacob, M. (1995). Telling the truth about history. New York: Norton.

Armbruster, B. B., \& Anderson, T. H. (1985). Producing 'considerate' expository text: Or easy reading is damned hard writing. Journal of Curriculum Studies, 17, 247-274.

Avery, P. G., Bird, K., Johnstone, S., Sullivan, J. L., \& Thaihammer, K. (1992).

Exploring political tolerance with adolescents. Theory \& Research in Social Education, 20(4), 386-420.

Avneri, A. (1984). The claim of dispossession: Jewish land settlement and the Arabs 
1878-1948 (Kfar-Blum Translation Group). New Brunswick: Transaction Books.

Banks, J. (1969). A content analysis of the black American in textbooks. Social Education, 33, 954-958.

Barari, H. (2009). Israelism: Arab scholarship on Israel, a critical assessment. Reading, United Kingdom: Ithaca Press.

Barlow, E. (1994). Evaluation of secondary level textbooks for coverage of the middle east and north africa (third ed.). Ann Arbor, MI: Center for Middle Eastern and North African Studies.

Beck, I. L., McKeown, M. G., \& Gromoll, E. W. (1989). Learning from social studies texts. Cognition and Instruction, 6(99-158)

Berelson, B. (1952). Content analysis in communication research. Glencoe, Illinois: The Free Press Publications.

Bernstein, B. (1968). Towards a new past. New York: Pantheon Books.

Bickerton, I., \& Klausner, C. (2005). A concise history of the Arab-Israeli conflict

(Fourth Edition). New Jersey: Prentice Hall.

Bienstock, B. W. (1995). Everything old is new again: Social history, the national history standards and the crisis in the teaching of high school American history. Journal of Social History, 29(1), 59. 
Bierstedt, R. (1955). The writers of textbooks. In L. J. Cronbach (Ed.), Text materials in modern education: A comprehensive theory and platform (pp. 96-128). Urbana, IL: University of Illinois Press.

Bigelow, W. (1989). Discovering Columbus: Rereading the past. Language Arts, 66, 635643.

Bolton, J. (2009). Did Obama's U.N. speech help or hurt America's world image? Message posted to http://www.foxnews.com/story/0,2933,554804,00.html

Bragdon, H. W. (1969). Dilemmas of a textbook author. Social Education, 33(3), 292298.

Broudy, E. (1975). The trouble with textbooks. Teachers College Record, 77(1), 13-34.

Brysiewicz, J. (2003). Collaboration: The essential element in the teaching american history initiative. OAH Newsletter, 31(4), p. 5.

Bush, G. W. (2002). Remarks announcing the teaching american history and civic education initiatives september 17, 2002. Weekly Compilation of Presidential Documents, 38(38), 1561.

Camicia, S. P. (2008). Deciding what is a controversial issue: A case study of social studies curriculum controversy. Theory and Research in Social Education, 36(4), 298-316.

Camicia, S. P. (2009). Identifying soft democratic education: Uncovering the range of civic and cultural choices in instructional materials. Social Studies, 100(3), 136-142. Carol, S. (2008). Middle East rules of thumb: Understanding the complexities of the 
Middle East (2nd edition). New York: iUniverse Inc.

Cartwright, D. (1953). Group dynamics, research and theory. Evanston, Ill: Row,

\section{Peterson.}

Chalmers, J. (2003). Mining the archive: Evaluating and improving a course. Teaching Theology \& Religion, 6(1), 35-42.

Chambliss, M. (1994). Why do readers fail to change their beliefs after reading persuasive text? In Garner and Alexander (Eds.), Beliefs about text and instruction with text (pp. 75-89). Hillsdale, NJ: Erlbaum.

Chambliss, M., \& Calfee, R. (1998). Textbooks for learning: Nurturing children's minds. Malden, Massachusetts: Blackwell Publishers.

Cheney, L. (1988). American memory. Washington D.C.: National Endowment for the Humanities.

Costo, R., \& Henry, J. (1970). Textbooks and the American Indian. San Francisco: Indian Historian Press.

Cremin, L. (1988). American education: The metropolitan experience, 1876-1980. Cambridge, Massachusetts: Harper and Row.

Crismore, A. (1984). The effects of a rhetorical textbook on students: Two studies of metadiscourse and interpersonal voice. Entry for the National Council of Teachers of English 1985 Promising Research Award Competition.

David, R. G. (2000). Imagining the past: The use of archive pictures in secondary school history textbooks. Curriculum Journal, 11(2), 225-246. 
Davis, O. L., Jr., et al., Ed. (1986). Looking at history: A review of major U.S. history textbooks. Washington, D.C., People for the American Way.

Downey, M., \& Metcalf, F. (1980). Do school history textbooks lie to children? reflections on Frances Fitzgerald's 'America revised.' AHA Newsletter, 18(2), 6.

Dutton, B. G. (1989). 'A content analysis of the treatment of religion during the colonial period of American history as presented in the seventh and eighth grade United States history textbooks published in the 1930s, 1950s, and 1980s.' (U. of Connecticut). Dissertation Abstracts International, 50 (4).

Education, A. C. o. (1949). Intergroup relations in teaching materials: A survey and appraisal. Washington, D. C.

Fitzgerald, F. (1979). America revised: History schoolbooks in the twentieth century. New York: Vintage Books.

Foster, S. J. (1998). Politics, parallels and perennial curriculum questions: The battle over school history in England and the United States. Curriculum Journal, 9(2), 153.

Foster, S. J. (1999). The struggle for American identity: Treatment of ethnic groups in United States history textbooks. History of Education, 28(3), 251-278.

Gagnon, P. (1987). Democracy's untold story: How world history textbooks shortchange our students. American Educator, 11, 19-46.

Gagnon, P. (1988). Why study history? The Atlantic, 262(5), 43-66.

Gal, M. D. (1981). Handbook of evaluation and selecting curriculum materials. Washington D.C.: Allyn \& Bacon. 
Garcia, J., \& Tanner, D. E. (1985). The portrayal of Black Americans in U.S. history textbooks. The Social Studies, 76(5), 200-204.

Garcia, J. (1993). The changing image of ethnic groups in textbooks. Phi Delta Kappan, 75(1), 29.

Gelvin, J. (2005). The Israel-Palestine conflict: One hundred years of war. New York:

\section{Cambridge University Press.}

Gilbert, M. (2005). The routledge atlas of the Arab-Israeli conflict. New York:

Routledge.

Glaser, B., \& Strauss, A. (1999). The discovery of grounded theory: Strategies for qualitative research (3rd ed.). New York: Aldine de Gruyter.

Gordy, L., Hogan, J., \& Pritchard, A. (2004). Assessing "herstory" of WWII: Content analysis of high school history textbooks. Equity \& Excellence in Education, 37(1), 80-91.

Graser, M. (2009). World history in a nation-state: The transnational disposition in historical writing in the united states. The Journal of American History, (March), 1038-1052.

Graves, M. F., \& Slater, W. H. (1986). Could textbooks be better written and would it make a difference? American Educator, 11, 35-41.

Griswold, W. (1975). The image of the Middle East in secondary school textbooks. New York: Middle East Studies Association of North America. 
Gutek, G. (2000). American education, 1945-2000: A history and commentary. Prospect Heights, IL: Waveland Press.

Hahn, C. \& Tocci, C. (1990). Classroom climate and controversial issues discussions: A five nation study. Theory and Research in Social Education, 18, 4, 344-362.

Harison, C. (2002). Teaching the French revolution: Lessons and imagery from nineteenth and twentieth century textbooks. History Teacher, 35(2), 137.

Haycock, K., \& Huang, S. (2001). Are today's high school graduates ready?. Washington D.C.: Education Trust.

Hertzberg, H. W. (1982). The teaching of history. In M. Kammen (Ed.), The past before us: Contemporary historical writing in the united states (pp. 474). Ithaca, New York: Cornell University Press.

Herz, M. (1979). How the cold war is taught. Social Education, 43, 2, 118-122.

Herzog, C. (1982). The Arab-Israeli wars. London: Arms and Armour Press.

Hess, D., \& Stoddard, J. (2007). 9/11 and terrorism: "the ultimate teachable moment" in textbooks and supplemental curricula. Social Education, 71(5), 231-236.

Hofman, A., Alpert, B., \& Schnell, I. (2007). Education and social change: The case of Israel's state curriculum. Curriculum Inquiry, 37(4), 303-328.

Holt, T. (1990). Thinking historically: Narrative, imagination and understanding. New York: College Entrance Examination Board. 
Hoyle, J., \& Collier, V. (2006). Urban CEO superintendents' alternative strategies in reducing school dropouts. Education and Urban Society, 36, pp. 69-90.

Isacoff, J. (2005). Writing the Arab-Israeli conflict: Historical bias and the use of history in political science. Perspective on Politics, 3(1), pp. 71-88.

Isacoff, J. (2006). Writing the Arab-Israeli conflict. New York: Lexington Books.

Issitt, J. (2004). Reflections on the study of textbooks. History of Education, 33(6), 683.

Jackson, A. (2008). High schools in the global age. Educational Leadership, 65(8), 5862.

Jackson, P. (1983). The reform of science education: A cautionary tale. Daedalus, 112(2), 143-166.

Janis, I. (1949). Language of politics: Studies in quantitative semantics. New York:

George W. Stewart.

Jarrar, S. A. (1976). 'Images of the Arabs in United States secondary school social studies textbooks: A content analysis and a unit development'. Florida State University. Dissertation Abstracts International, 37 (6).

Johnson, P. (2009). The 21st century skills movement. Educational Leadership, 67(1), p. 11.

Joseph, G. I. (1988). Black feminist pedagogy and schooling in capitalist white America. In M. Cole (Ed.), Bowles and Gintis revisited: Correspondence and contradiction in education theory (pp. 174-186). New York: Falmer. 
Kaltsounis, T. (1988). A critique of Gilbert T. Sewall's American history textbooks. Social Education, 52(4), 252-53.

Kammen, M. (1980). The past before us: Contemporary historical writing in the united states. Ithaca, New York: Cornell university press.

Kane, M. (1970). Minorities in textbooks. Chicago: Anti-Defamation League.

Keith, K. W. (2005). America and the post 9/11 world: Education for survival. Journal of Public Affairs, 8, 1-9.

Kliebard, H. (1991). In Jackson P. (Ed.), Handbook of research on curriculum. New York: Macmillan Publishing Company.

Krippendorff, K. (1969). The analysis of communication content; developments in scientific theories and computer techniques. New York: John Wiley \& Sons.

Krippendorf, K. (2006). Content analysis. An introduction to it methodology. Thousand Oaks/London/New Delhi: Sage.

Kuhn, D. (1992). Thinking as argument. Harvard Educational Review, 62, 155-178.

Larsen, M. R. (1991). 'Ahistoricism and fragmentation in united states history textbooks of the 1980's at elementary, middle, and high school levels: A content analysis and study of influences'. Michigan State University). Dissertation Abstracts International, 51 (12).

Lavere, D. B. (2008). The quality of pedagogical exercises in U.S. history textbooks. Social Studies, 99(1), 3-8. 
Lea, D., \& Rowe, A. (Eds.). (2002). A survey of Arab-Israeli relations 1947-2001 (First Edition). London: Europa Publications.

Lin, L., Zhao, Y., Ogawa, M., Hoge, J., \& Kim, B. Y. (2009). Whose history? An analysis of the Korean war in history textbooks from the United States, South Korea, Japan, and China. Social Studies, 100(5), 222-232.

Lindaman, D. \& Ward, K. (2004). History lessons: How textbooks from around the world portray U.S. history. New York: The New Press.

Link, A. (1985). The american historical association: 1884-1984: Retrospect and prospect. American Historical Review, 90, 1-17.

Lochery, N. (2001). Scholarship or propaganda: Works on Israel and the Arab-Israeli conflict, 2001: Review article. Middle Eastern Studies, 37(4), pp. 219-236.

Loewen, J. (2008). Lies my teacher told me: Everything your American history textbook got wrong. New York: Simon and Schuster.

Marcus, L. (1961). The treament of minorities in secondary school textbooks. New York: Anti-Defamation League of B'nai B'rith.

Marty, M. (1982). America revising. History Teacher, 15(4), 545-564.

Masur, L. (1998). "Pictures have no become a necessity: The use of images in American history textbooks. The Journal of American History. 84, 4, 1409-1424. 
McKenzie, M. (2005). A CASE STUDY IN HISTORY OF EDUCATION DURING THE 1970S: Published stories of the midwest history of education society Information Age Publishing.

McLaughlin, A., Adams, H., George, F., Albert, H., Haskins, C., Salmon, L., et al. (1899). The study of history in the schools: Report to the american historical association. New York: American Historical Association.

Mehta, J. (2006). Transforming american education: Ideas and the rise of accountability politics American Sociological Association.

Metcalf, F. D., \& Downey, M. T. (1980). Do school history textbooks lie to children? reflections on frances fitzgerald's 'america revised.'. AHA Newsletter, 18(2), 6.

Metcalf, L. E. (1963). In Gage N. L. (Ed.), Handbook of research on teaching [Research on teaching the social studies]. Chicago: Rand McNally.

Miles, M. B., \& Huberman, A. M. (1994). Qualitative data analysis (2nd ed. ed.). Newbury Park, CA: Sage.

Montgomery, K. (2006). Racialized hegemony and nationalist mythologies: Representations of war and peace in high school history textbooks, 1945-2005. Journal of Peace Education, 3(1), 19-37.

Moore, J. (2006). Teaching about Islam in secondary schools: Curricular and pedagogical considerations. Equity \& Excellence in Education, 39(3), 279-286. 
Moreau, J. (2003). Schoolbook nation: Conflicts over American history textbooks from the civil war to the present. Ann Arbor: The University of Michigan Press.

Morgan, H. (2008). American school textbooks: How they portrayed the Middle East from 1898 to 1994. American Educational History Journal, 35(2), 315-330.

Moskowitz, E. (1988). Lessons in achievement in american history high school textbooks of the 1950s and 1970s. Pennsylvania Magazine of History \& Biography, 112(2), 249-271.

Munro, W. (1933). Report of the committee on college and university teaching. Bulletin of the American Association of University Professors, 19(May), 61-70.

Nash, G. B., C. Crabtree, \& R.E. Dunn. (1998). History on trial. New York: Knopf.

Nash, G. B. (1997). Reflections on the national history standards. National Forum, 77(3), 14.

National Commission on Excellence in Education. (1983). A nation at risk No. 28-29). Washington, D.C.: Government printing office.

Newmann, F. M. (1988). Can depth replace coverage in the high school curriculum? Phi Delta Kappan, 69, 345-348.

Obama, B. (2009), Obama's speech to the United Nations general assembly. New York Times. http://www.nytimes.com/2009/09/24/us/politics/24prexy.text.html Retrieved, March 19, 2010. 
Ogawa, M. (2004). The treatment of Japanese American internment during world war ii in United States history textbooks. International Journal of Social Education, 19(1; 1), 35-47.

Orrill, R., \& Shapiro, L. (2005). From bold beginnings to an uncertain future: The discipline of history and history education. American Historical Review, 110(June), 727-751.

Osgood, C. (1957). The measurement of meaning. Illinois: University of Illinois Press.

Peloso, V. (1972). A third world perspective on the writing of United States history for the 1970s. Studies in Comparative International Development, 7(1), 85-90.

Perlmutter, D. D. (1997). Manufacturing visions of society and history in textbooks. Journal of Communication, 47(3), 68.

Pingel, F. (2008). Can truth be negotiated? History textbook revision as a means to reconciliation. The Annals of the American Academy, 617, 181-198.

Podeh, E. (2000). The Arab Israeli conflict in Israeli history textbooks, 1948-2000. London: Bergin and Garvey.

Porat, D. A. (2006). Who fired first? Students' construction of meaning from one textbook account of the Israeli Arab conflict. Curriculum Inquiry, 36(3), 251-271.

Postman, N. (1986). Amusing ourselves to death. New York: Viking Penguin Inc.

Ravitch, D. (2003). The language police: How pressure groups restrict what students learn. New York: Vintage Books. 
Ravitch, D. (2004). A consumer's guide to high school history textbooks (Curriculum and Instruction. Washington D.C.: Thomas B. Fordham Institute.

Ravitch, D. (2010). A century of skills movements. American Educator, 34(1), pp. 12-13.

Regester, C. (1991). Visual and verbal content in U.S. history textbooks of the 1950s and 1980s. Reading Improvement, 28(1), 14-25.

Reich, B., Goldberg, J., Gotowicki, S., Silverburg, S., \& Erickson, M. (Eds.). (1996). An historical encyclopedia of the Arab-Israeli conflict. Westport, Connecticut:

\section{Greenwood Press.}

Robelen, E. (2010). Texas' influence over textbook content could shift with changes in the market. Education Week, 29, 30.

Roberts, C. (1997). Text analysis for the social sciences: Methods for drawing statistical inferences from texts and transcripts. Mahwah, New Jersey: Lawrence Erlbaum Associates.

Rock, M. (1996). The Arab-Israeli conflict as depicted in children's and young adult non-fiction literature. Master's Thesis, Queens College, The City University of New York.

Romanowski, M. H. (1996). Problems of bias in history textbooks. Social Education, 60(3), 170-173. 
Romanowski, M. H. (1995). American history by the book: Teachers using textbooks. Paper presented at the Annual Meeting of the American Educational Research Association (San Francisco, CA, April 18-22, 1995).

Romanowski, M. H. (2003). Religion in contemporary U.S. history textbooks. Social Studies, 94(1), 29.

Romanowski, M. H. (2009). What you don't know can hurt you: Textbook omissions and 9/11. Clearing House, 82(6), 290-296.

Ross, E. W., \& Marker, P. M. (2005). Social studies: Wrong, right, or left? A critical response to the Fordham institute's where did social studies go wrong? Social Studies, 96(4), 139-142.

Ryan, P. A., \& Townsend, J. S. (2010). Representations of teachers' and students' inquiry in 1950s television and film. Educational Studies: Journal of the American Educational Studies Association, 46(1), 44-66.

Russell, W. (2010). Teaching social studies in the 21st century: A research study of secondary social studies teachers' instructional methods and practices. Action in Teacher Education, 32(1), pp. 65-72.

Sadker, M., \& Sadker, D. (1994). Failing at fairness: How America's schools cheat girls. New York: Charles Scribner's Sons.

Schachter, R. (2009). Social studies for the 21st century: Changing business as usual with a new map for K12 social studies. District Administration, 45(1), pp. 81-83. 
Sanchez, T. R. (2007). The depiction of Native Americans in recent (1991-2004) secondary American history textbooks: How far have we come? Equity \& Excellence in Education, 40(4), 311-320.

Schlesinger Jr., A. (1998). The disuniting of America: Reflections on a multicultural society. New York: W. W. Norton.

Schulman, B. J. (1999). Out of the streets and into the classroom? The new left and the counterculture in United States.. Journal of American History, 85(4; 4), 1527-1534.

Schwandt, T. (1997). Qualitative inquiry: A dictionary of terms. London: Sage Publications.

Senechal, D. (2010). The most daring education reform of all. American Educator, 34(1), pp. 4-13.

Sewall, G. (1987). American history textbooks: An assessment of quality. New York: Columbia University.

Sewall, G. (1988). Literary lackluster: The unhappy state of American history textbooks. American Educator, 12, 32-37.

Sewall, G. (1988). American history textbooks: A literary disaster? OAH Newsletter, $16(2)$.

Sewall, G. (1992). Social studies review, numbers 1-12, 1989-1992. New York: The American Textbook Council.

Sewall, G. (2003). Islam and the textbooks. Middle East Quarterly, 10(3), 69. 
Sewall, G. (2004). World history textbooks: A review. New York: The American Textbook Council.

Sewall, G. (2008). Islam in the classroom: What the textbooks tell us. New York: American Textbook Council.

Shedd, J. (2004). History in the present tense: Engaging students through inquiry and action (book). History Teacher, 37(3; 3), 407-408.

Shug, M. C., Western, R. D., \& Enochs, L. G. (1997). Why do social studies teachers use textbooks? The answer may lie in economic theory. Social Education, 61, 97-101.

Siler, C. R. (1987). Content analysis: A process for textbook analysis and evaluation. International Journal of Social Education, 1(3), 78-99.

Siler, C. R. (1990). United states history textbooks: Cloned mediocrity. International Journal of Social Education, 4(3), 10-31.

Smith, C. (2010). Palestine and the Arab-Israeli conflict (Seventh Edition). Boston: Bedford/St. Martin's.

Spring, J. (2000). American education (9th edition ed.). Boston: McGraw-Hill.

Steup, M. (2005). Stanford encyclopedia of philosophy. http://0plato.stanford.edu.library.cedarville.edu/search/searcher.py?page=2\&query=episte $\underline{\text { mology }}$

Stone, P. (1966). The general inquirer; a computer approach to content analysis.

Massachusetts: M.I.T Press. 
Stotsky, S. (2004). The stealth curriculum: Manipulating America's history teachers (Curriculum and Instruction. Washington D.C.: Thomas B. Fordham Institute.

Tracy, J. (2003). Racing through history. Journal of Education, 184(2), 63-68.

Trecker, J. L. (1971). Women in U.S. history high school textbooks. Social Education, $35,249-260$.

Tunnell \& Ammon. (1993). The story of ourselves: Teaching history through children's literature. Portsmouth, New Hampshire: Heinemann.

Tyson-Bernstein, H. (1988). America's textbook fiasco: A conspiracy of good intentions. Washington, D.C.: The Council for Basic Education.

U.S. Census Bureau. (2004). Exports from manufacturing establishments: 2001. Washington D.C.: U.S. Department of Commerce.

Vitz, P. C. (1986). Profiles in education. Education Update, 9(4-6).

Wade, R. C. (1993). Content analysis of social studies textbooks: A review of ten years of research. Theory \& Research in Social Education, 21(3), 232-256.

Walker, B., Shippen, M. E., Alberto, P., Houchins, D. E., \& Cihak, D. F. (2005). Using the expressive writing program to improve the writing skills of high school students with learning disabilities. Learning Disabilities Research \& Practice (Blackwell Publishing Limited), 20(3), 175-183.

Ward, P. L. (1980). America revised. History \& Theory, 19(3), 362. 
Watt, M. G. (2007). Research on the textbook publishing industry in the United States of America. Online Submission.

Wehling, B. (2007). Building a 21st century U.S. education system. Washington D.C.: National Commission on Teaching and America's Future.

Weber, R. (1990). Basic content analysis (Second Edition ed.). Newbury Park, London, New Delhi: Sage Publications.

Wiggins, G. (1989). The futility of trying to teach everything important. Educational Leadership, 47, 44-59.

Willingham, D. (2010). How knowledge helps: It speeds and strengthens reading comprehension, learning--and thinking. American Educator, 30(1).

Wilson, E. K., Haas, M. E., Laughlin, M. A., \& Sunal, C. S. (2002). Teachers' perspectives on incorporating current controversial issues into the social studies curriculum. International Social Studies Forum, 2(1), 31.

Wineburg, S. (1991). On the reading of historical texts: Notes on the breach between school and academy. American Educational Research Journal, 28, 495-519. Wineburg, S. (2003). Teaching the mind good habits. The Chronicle of Higher Education, April 11, 2003, B20.

Wolworth, A. (1938). School histories at war. Cambridge: Harvard University Press.

Woodward, A. (1982). Identifying representative textbooks in U.S. history. Theory and Research in Education, X(4), 39-47. 
Woodward, A. (1987). Textbooks: Less than meets the eye. Journal of Curriculum Studies, 19, 511-526.

Woodward, A., Elliott, D., \& Nagel, K. (1988). Textbooks in school and society: An annotated bibliography and guide to research. New York: Garland Publishing.

Wrobel, D. (2008). A lesson from the past and some hope for the future: The history academy and the schools, 1880-2007. History Teacher, 41(2), 152-162.

Yarema, A. E. (2002). A decade of debate: Improving content and interest in history education. History Teacher, 35(3), 389.

Young, R., \& Sharifzadeh, V. (2003). Aftereffect of 9-11: A call to balance patriotism and multiculturalism in the classroom. Multicultural Perspectives, 5(2), 34-38.

Zinn, H. (1995). A people's history of the United States: 1492-present. New York: HarperPerennial. 


\section{Appendix A}

This appendix lists all textbooks used in this present thesis, along with other similar content analysis studies in which these same textbooks were analyzed. The American Textbook Council currently lists textbooks with an asterisk as having been included "in major adoptions, that, combined, hold an estimated 80 percent of the national market in the United States and world history, grades eight to twelve."

\section{McDougal Littell (Houghton Mifflin)}

\section{2: The Making of Modern America (Canfield and Wilder)}

*1948 version used in America Revised by Frances Fitzgerald.

*1952 version used in Molding the Good Citizen: The Politics of High School History Texts by Robert Lerner, Althea K. Nagai, and Stanley Rothman. All state departments of education were surveyed with 72 percent responding. The largest 120 school districts in the nation were also surveyed to obtain titles used prior to the 1980s since most did not have statewide adoption prior to 1980. The list came from the Digest of Educational Statistics as compiled by Dr. Vance Grant in education statistics for the U.S. Department of Education. The top five books in the state and district lists were merged into a single list per decade. Top ranking books common to both state and district lists were given priority in the study.

*1952 version used in Has the Texas Revolution Changed? A Study of U.S. History Textbooks from 1897-2003 by Connee Duran. The author studied five textbooks over a span of 100 years, with no attempt to determine which books had been widely used.

*1954 version used in Visual and Verbal Content of U.S. History Textbooks of the 1950s and 1980s by Charlene Regester. She used textbooks adopted by four of the largest textbook purchasing states: Texas, California, Florida and North Carolina. She also cross referenced this with textbooks appearing the most frequently on state or district level adoption lists of these four states.

\section{2: The Making of Modern America (Canfield and Wilder)}

*1962 version used in Molding the Good Citizen: The Politics of High School History Texts by Robert Lerner, Althea K. Nagai, and Stanley Rothman. All state departments of education were surveyed with 72 percent responding. The largest 
120 school districts in the nation were also surveyed to obtain titles used prior to the 1980s since most did not have statewide adoption prior to 1980. The list came from the Digest of Educational Statistics as compiled by Dr. Vance Grant in education statistics for the U.S. Department of Education. The top five books in the state and district lists were merged into a single list per decade. Top ranking books common to both state and district lists were given priority in the study.

*1964 version used in Women in U.S. History High School Textbooks by Janice Law Trecker. She surveyed twelve of what she claimed were the most popular U.S. history textbooks.

*1964 version used in Textbooks and the American Indian by the American Indian Historical Society. Over three hundred books were reviewed, all were claimed to be currently in use in classrooms, and not yet retired by publishers.

*1964 version used in How Much of the Sky? Women in American High School History Textbooks from the 1960s, 1980s and 1990s by Roger Clark. Sampled 19 textbooks, six each from the 1960s, 1980s, and 1990s. 1990 textbooks were taken from the American Textbook Council's website of "widely adopted" books. 1980 textbooks were derived from a simple random sample of Mary Kay Thompson Tetreault's study, who wrote to textbook companies at the Nation Council for the Social Studies Annual Conference in 1980. 1960 textbooks were a simple random sample of Janice Law Trecker's list of the most popular textbooks of the 1960s.

\section{5: This is America's Story (Wilder, Ludlum, and Brown)}

*1970, 1975 version used in America Revised by Frances Fitzgerald.

*1975 version used in Lessons in Achievement in American History High School Textbooks of the 1950s and 1970s by Eva Moskowitz. The author chose six books from the 1950's and eight from the 1970s. The author reasons that because textbooks of the 1950s are so similar, six were simply chosen from the decade. 1970s textbooks were chosen more carefully to reflect the educational and political differences in textbooks of this decade.

\section{6: This is America's Story (Wilder, Ludlum, and Brown)}

\section{6: The Americans: a history (Winthrop, Greenblatt, and Bowes)}

*1982 version used in How Much of the Sky? Women in American High School History Textbooks from the 1960s, 1980s and 1990s by Roger Clark. Sampled 19 textbooks, six each from the 1960s, 1980s, and 1990s. 1990 textbooks were taken from the American Textbook Council's website of "widely adopted" books. 1980 textbooks were derived from a simple random sample of Mary Kay Thompson Tetreault's study, who wrote to textbook companies at the Nation Council for the Social Studies Annual Conference in 1980. 1960 textbooks were a simple 
random sample of Janice Law Trecker's list of the most popular textbooks of the 1960s.

*1982 version used in The Portrayal of Black Americans in U.S. History

Textbooks by Jesus Garcia and David Tanner. Texts were selected from the Social Studies Laboratory of the Department of Curriculum and Instruction at Texas A\&M University.

*1985 version used in United States History Textbooks: Cloned Mediocrity by Carl Siler. He used a representative sample of 14 books from the submission list of Texas in 1986 and the 1984 official adoption list from the Indiana Departmen $t$ of Education.

*1988 version used in Fleeing Democratic Ideals by Michael Romanowski. The author used the top five publishing companies' "best sellers" according the marketing departments of each publisher.

*1992 version used in Evaluation of Secondary-Level Textbooks for Coverage of the Middle East and North Africa by the Middle East Studies Association and the Middle East Outreach Council; Elizabeth Barlow, editor.

*1996 version used in The Treatment of Asian Americans in U.S. History Textbooks Published 1994-1996 by Violet Harada. This author based textbook selection on a survey conducted by the Hawaii Department of Education to identify the most widely used textbooks in U.S. history courses in the state's public schools.

*1998 version used in How Much of the Sky? Women in American High School History Textbooks from the 1960s, 1980s and 1990s by Roger Clark. Sampled 19 textbooks, six each from the 1960s, 1980s, and 1990s. 1990 textbooks were taken from the American Textbook Council's website of "widely adopted" books. 1980 textbooks were derived from a simple random sample of Mary Kay Thompson Tetreault's study, who wrote to textbook companies at the Nation Council for the Social Studies Annual Conference in 1980. 1960 textbooks were a simple random sample of Janice Law Trecker's list of the most popular textbooks of the 1960s.

\section{****2003: The Americans (Danzer)}

*1998 version used in Assessing 'Herstory' of WWII: Content Analysis of High School History Textbooks" by Laurie Gordy, Jennifer Hogan, and Alice Pritchard. Sample included ten of the major textbook publishers. *2000 version used in, The Quality of Pedagogical Exercises in U.S. History Textbooks by Bruce Lavere. The author chose thirteen textbooks, five of them secondary, currently in use in the state of South Carolina. 
*2002 version used in The Language Police: How Pressure Groups Restrict What Students Learn by Diane Ravitch. There is no explanation of how the author chose the textbooks that were evaluated.

*2003 version used in Framing American Indians as the 'First Americans': Using Critical Multiculturalism to Trouble the Normative American Story by Annalee Good. The author used six U.S. History textbooks from the American Textbook Council's list of widely adopted books.

*2003 version used in A Consumer's Guide to High School History Textbooks by Diane Ravitch for the Thomas B. Fordham Institute. All six United States history textbooks were claimed to be "in wide circulation and broadly representative of the genre."

*2005 version used in The Limits of Master Narratives in History Textbooks: An Analysis of Representations of Martin Luther King, Jr. by Derrick Alridge. This author examined six books and chose this one based on the list created by the American Textbook Council for widely used textbooks.

\section{Holt, Rinehart, Winston (Harcourt)}

\section{0: America's History (Todd and Curti)}

*1950 version used in Fitzgerald's "America Revised."

*1950 version used in Lessons in Achievement in American History High School Textbooks of the 1950s and 1970s by Eva Moskowitz. The author chose six books from the 1950's and eight from the 1970s. The author reasons that because textbooks of the 1950s are so similar, six were simply chosen from the decade. 1970s textbooks were chosen more carefully to reflect the educational and political differences in textbooks of this decade.

\section{6: The Rise of the American Nation (Todd and Curti)}

*1961, 1966, 1969, 1972 version used in America Revised by Frances Fitzgerald.

*1966 version used in Women in U.S. History High School Textbooks by Janice Law Trecker. She surveyed twelve of what she claimed were the most popular U.S. history textbooks.

*1966 version used in How Much of the Sky? Women in American High School History Textbooks from the 1960s, 1980s and 1990s by Roger Clark. Sampled 19 textbooks, six each from the 1960s, 1980s, and 1990s. 1990 textbooks were taken from the American Textbook Council's website of "widely adopted" books. 1980 textbooks were derived from a simple random sample of Mary Kay Thompson Tetreault's study, who wrote to textbook companies at the Nation Council for the Social Studies Annual Conference in 1980. 1960 textbooks were a simple 
random sample of Janice Law Trecker's list of the most popular textbooks of the 1960s.

*1966 and 1972 version used in Molding the Good Citizen: The Politics of High School History Texts by Robert Lerner, Althea K. Nagai, and Stanley Rothman. All state departments of education were surveyed with 72 percent responding. The largest 120 school districts in the nation were also surveyed to obtain titles used prior to the 1980s since most did not have statewide adoption prior to 1980 . The list came from the Digest of Educational Statistics as compiled by Dr. Vance Grant in education statistics for the U.S. Department of Education. The top five books in the state and district lists were merged into a single list per decade. Top ranking books common to both state and district lists were given priority in the study.

\section{7: The Rise of the American Nation (Todd and Curti)}

*1974 version used in Lessons in Achievement in American History High School Textbooks of the 1950s and 1970s by Eva Moskowitz. The author chose six books from the 1950's and eight from the 1970s. The author reasons that because textbooks of the 1950s are so similar, six were simply chosen from the decade. 1970s textbooks were chosen more carefully to reflect the educational and political differences in textbooks of this decade.

*1977 version used in How the Cold War is Taught: Six American History Textbooks Examined by Martin F. Herz. He used, according to Carl Siler in his 1986 article, Content Analysis: A Process for Textbook Analysis and Evaluation, "a systematic process that involved checking with textbook authors, senior educators, and high school teachers in different parts of the country."

*1977 version used in A Study of Historical Source Materials on Women 's Topics Which Appear in United States History Textbooks: A Content Analysis by Beverly Ann Hogg Reid. The author surveyed the District of Columbia and five school districts from each state, taken from the Education Directory using a random number table. A request for the title and publication date of U.S. History books used by the schools in grades nine to twelve was made to 247 schools, with 173 replying, for a response rate of 70 percent. The 1982 version was also included in the study as a more current edition.

*1982 version used in Benjamin Franklin to Watergate: The Press in U.S. History Textbooks Dan Fleming. No explanation of how the textbooks were chosen.

*1982 version used in United States History Textbooks: Cloned Mediocrity by Carl Siler. He used a representative sample of 14 books from the submission list of Texas in 1986 and the 1984 official adoption list from the Indiana Department of Education. 


\section{6: Triumph of the American Nation (Todd and Curti)}

*1982 version used in Molding the Good Citizen: The Politics of High School History Texts by Robert Lerner, Althea K. Nagai, and Stanley Rothman. All state departments of education were surveyed with 72 percent responding. The largest 120 school districts in the nation were also surveyed to obtain titles used prior to the 1980s since most did not have statewide adoption prior to 1980. The list came from the Digest of Educational Statistics as compiled by Dr. Vance Grant in education statistics for the U.S. Department of Education. The top five books in the state and district lists were merged into a single list per decade. Top ranking books common to both state and district lists were given priority in the study.

*1982 version used in Fourteen Ninety-Two in the Textbooks: A Critique by Charlie Sugnet. Author chose seven books commonly used or likely to be adopted in Minnesota schools.

*1982 version used in Visual and Verbal Content of U.S. History Textbooks of the 1950s and 1980s by Charlene Regester. She used textbooks adopted by four of the largest textbook purchasing states: Texas, California, Florida and North Carolina. She also cross referenced this with textbooks appearing the most frequently on state or district level adoption lists of these four states.

*1982 version used in The Portrayal of Black Americans in U.S. History Textbooks by Jesus Garcia and David Tanner. Texts were selected from the Social Studies Laboratory of the Department of Curriculum and Instruction at Texas A\&M University.

*1986 version used in Ahistoricism and Fragmentation in United States History Textbooks of the 1980s at Elementary, Middle, and High School Levels: A Content Analysis by Mark Larsen. The author began with all United States History textbooks used in Michigan public schools in the 1980s, and then obtained a sample population through three surveys conducted by the Michigan Department of Education to determine the most frequently used United States history textbooks.

*1986 version used in Looking at History: A Review of Major U.S. History Textbooks by O.L. Davis, and sponsored by People for the American Way. Texts selected for review were those submitted to the 1985 Texas State Textbook Committee, as well as other "best-selling texts available in other states". This textbook was labeled as "outstanding" by the review panel.

*1986 version used in American History Textbooks: An Assessment of Quality by Gilbert Sewall. This study concentrated on what was claimed to be "established texts in the marketplace." 
*1986 version used in Lies My Teacher Told Me by James Loewen. This book was a general review of twelve United States history textbooks written between 1974 and 1991.

*1990 version used in Fleeing Democratic Ideals by Michael Romanowski . The author used the top five publishing companies "best sellers" according the marketing departments of each publisher.

\section{5: Todd and Curti's the American Nation (Todd and Curti)}

\section{****2003: American Nation (Boyer)}

*1995 version used in America in World War II: An Analysis of History Textbooks From England, Japan, Sweden, and the United States by Stuart Foster and Jason Nicholls. Two textbooks were selected from each country from within a particular publication time frame and all textbooks were designed for use at the high school level. No attempt was made to explain how the authors determined what constituted a "popular" textbook.

*1995 version used in The Treatment of Asian Americans in U.S. History Textbooks Published 1994-1996 by Violet Harada. This author based textbook selection on a survey conducted by the Hawaii Department of Education to identify the most widely used textbooks in U.S. history courses in the state's public schools.

*1998 version used in Assessing 'Herstory' of WWII: Content Analysis of High School History Textbooks" by Laurie Gordy, Jennifer Hogan, and Alice Pritchard. Sample included ten of the major textbook publishers.

*2001 version used in The Language Police: How Pressure Groups Restrict What Students Learn by Diane Ravitch. There is no explanation of how the author chose the textbooks that were evaluated.

*2003 version used in Framing American Indians as the 'First Americans': Using Critical Multiculturalism to Trouble the Normative American Story by Annalee Good. The author used six U.S. History textbooks from the American Textbook Council's list of widely adopted books.

*2003 version used in A Consumer's Guide to High School History Textbooks by Diane Ravitch for the Thomas B. Fordham Institute. All six United States history textbooks were claimed to be "in wide circulation and broadly representative of the genre." This book earned Ravitch's rating of "runner up" behind Glencoe's The American Journey, which she considered the best overall of the six American history texts reviewed.

\section{Prentice Hall (Pearson)}


1957: The United States-the History of a Republic (Hofstadter)

*1957 version used in Women in U.S. History High School Textbooks by Janice Law Trecker. She surveyed twelve of what she claimed were the most popular U.S. history textbooks.

*1957 version used in How Much of the Sky? Women in American High School History Textbooks from the 1960s, 1980s and 1990s by Roger Clark. Sampled 19 textbooks, six each from the 1960s, 1980's, and 1990's. 1990 textbooks were taken from the American Textbook Council's website of "widely adopted" books. 1980 textbooks were derived from a simple random sample of Mary Kay Thompson Tetreault's study, who wrote to textbook companies at the Nation Council for the Social Studies Annual Conference in 1980. 1960 textbooks were a simple random sample of Janice Law Trecker's list of the most popular textbooks of the 1960s.

\section{7: The United States-the History of a Republic (Hofstadter)}

*1984 version used in United States History Textbooks: Cloned Mediocrity by Carl Siler. He used a representative sample of 14 books from the submission list of Texas in 1986 and the 1984 official adoption list from the Indiana Department of Education.

*1988 version used in Ahistoricism and Fragmentation in United States History Textbooks of the 1980's at Elementary, Middle, and High School Levels: A Content Analysis by Mark Larsen. The author began with all United States History textbooks used in Michigan public schools in the 1980's, and then obtained a sample population through three surveys conducted by the Michigan Department of Education to determine the most frequently used United States history textbooks.

\section{6: The United States (Hofstadter)}

\section{6: The American Nation (Davidson)}

*1998 version used in Assessing 'Herstory' of WWII: Content Analysis of High School History Textbooks" by Laurie Gordy, Jennifer Hogan, and Alice Pritchard. Sample included ten of the major textbook publishers.

*1994 version used in Evaluation of Secondary-Level Textbooks for Coverage of the Middle East and North Africa by the Middle East Studies Association and the Middle East Outreach Council; Elizabeth Barlow, editor.

*2005 version used in Whose History? An analysis of the Korean War in History Textbooks from the United States, South Korea, Japan, and China by Lin Lin. 
The author chose books that had been published by major publishers in the market.

\section{5: America: Pathways to the Present (Cayton)}

*1995 version used in Assessing 'Herstory' of WWII: Content Analysis of High School History Textbooks" by Laurie Gordy, Jennifer Hogan, and Alice Pritchard. Sample included ten of the major textbook publishers.

*1998 version used in America in World War II: An Analysis of History Textbooks From England, Japan, Sweden, and the United States by Stuart Foster and Jason Nicholls. Two textbooks were selected from each country from within a particular publication time frame and all textbooks were designed for use at the high school level. No attempt was made to explain how the authors determined what constituted a "popular" textbook.

*1998 version used in How Much of the Sky? Women in American High School History Textbooks from the 1960s, 1980s and 1990s by Roger Clark. Sampled 19 textbooks, six each from the 1960s, 1980s, and 1990s. 1990 textbooks were taken from the American Textbook Council's website of "widely adopted" books. 1980 textbooks were derived from a simple random sample of Mary Kay Thompson Tetreault's study, who wrote to textbook companies at the Nation Council for the Social Studies Annual Conference in 1980. 1960 textbooks were a simple random sample of Janice Law Trecker's list of the most popular textbooks of the 1960s.

\section{****2005: America: Pathways to the Present (Cayton)}

*2000 version used in The Quality of Pedagogical Exercises in U.S. History Textbooks by Bruce Lavere. The author chose thirteen textbooks, five of them secondary, currently in use in the state of South Carolina.

*2002 version used in The Language Police: How Pressure Groups Restrict What Students Learn by Diane Ravitch. There is no explanation of how the author chose the textbooks that were evaluated.

*2002 version used in Framing American Indians as the 'First Americans': Using Critical Multiculturalism to Trouble the Normative American Story by Annalee Good. The author used six U.S. History textbooks from the American Textbook Council's list of widely adopted books.

*2003 version used in Treatment of Japanese-American Internment During World War II in U.S. History Textbooks by Masato Ogawa. Six textbooks were chosen from Idaho's adoption list in 2002. 
*2003, 2005, and 2007 versions reviewed in Islam and the Classroom: What the Textbooks Tell Us by Gilbert Sewall for the American Textbook Council. The textbooks chosen were tailored to California standards.

*2003 version used in A Consumer's Guide to High School History Textbooks by Diane Ravitch for the Thomas B. Fordham Institute. All six United States history textbooks were claimed to be "in wide circulation and broadly representative of the genre."

*2005 version used in The Limits of Master Narratives in History Textbooks: An Analysis of Representations of Martin Luther King, Jr. by Derrick Alridge. This author examined six books and chose this one based on the list created by the American Textbook Council for widely used textbooks.

*2005 Modern American history version used in Whose History? An analysis of the Korean War in History Textbooks from the United States, South Korea, Japan, and China by Lin Lin. The author chose books that had been published by major publishers in the market. 


\section{Appendix B}

This appendix contains edition specific information on each textbook and for each category of analysis. Decade summaries in chapter four were derived from the specific information in this appendix.

\section{Mandate System/Balfour Declaration/1948 War/Establishment of Israel:}

\section{1. "What are the underlying problems which have generated this discourse" (Larsen, 1991)?}

(HM 1952) The 1952 Houghton Mifflin (HM) text does not mention Palestine at all, except to include it on a map displaying Axis territories between 1940 and 1944 (p. 710 ). (Holt 1950) The 1950 Holt (previously Harcourt, Brace and Company) textbook first mentions Palestine in the context of a discussion on the benefits of the United Nations, which "prevented or ended armed conflict" in this and other regions since the creation of the United Nations (p. 803). Palestine is listed with India, Pakistan, and Indonesia as having been areas where UN intervention was necessary and successful. Tensions in the Middle East are highlighted in the context of East-West conflict.

(PH 1957) This text first mentions the Middle East, again in the context of East-West tensions, describing it as "strategic" and "the weakest spot in western resistance to communist penetration" (p. 753).

(1962 HM) Israel is first mentioned in the context of the 1956 Suez Canal Crisis. Israel's beginnings and historic tensions in the Middle East are not mentioned except to say that, "Arab nations had never recognized the new republic of Israel...[and] had vowed to drive Israel into the sea" (pp. 780-781). 
(1966 Holt) This textbook is unique in that it explains the mandate system that was established after WWI, although Israel is not mentioned specifically. Although it does not go into details, the explanation includes the requirement that the new owners of the mandates were accountable to the League of Nations for their colonial administrations. The book goes into more detail on the mandate system when discussing rising tensions in the Middle East after WWII. Problems in Palestine are specifically cited when Great Britain, “...voluntarily gave up [their] mandate [and] the Jews in Palestine proclaimed the independence of the new state of Israel" (p. 773). It is interesting to note that all of the above is discussed under the textbook heading, "Communist Aggression Leads to 'Hot War' in Asia”, signifying that the Middle East was not the main focal point of the text's section on postwar tensions.

(PH 1967) In this text, Israel is first mentioned under the text heading, "The Truman Administration and Foreign Affairs", amid discussion on the end of British supremacy in the Mediterranean. This text spends less time than the last PH edition on Israel's declaration of statehood, and more time on why and how Great Britain gave up it's mandate: "In March, 1946, Britain had acknowledged the independence of Transjordan (renamed Jordan in 1949), and in April, 1947, had turned over the future of Palestine to the U.N., leading in May, 1948, to the creation, with mixed United States reactions, of the independent state of Israel” (p. 815).

(HM 1975) The first mention of Israel is under the text heading, "President Eisenhower also faces Cold War problems", and is in the context of discussion on the 1956 Suez Canal Crisis. 
(Holt 1977) This edition's account remains largely unchanged from the 1966 edition. Israel, and tensions in the Middle East are first mentioned under the heading, “ 'Hot War' in Asia as a result of Communist Aggression." Explaining that Palestine had been ruled by Great Britain under a mandate from the League of Nations since World War I, the text explains that, “...when Great Britain voluntarily gave up this mandate, the Jews in Palestine proclaimed the independence of the new state of Israel" (p. 684).

(PH 1976) This edition also remained mostly unchanged from the 1967 edition. First mention of the Middle East is found under the heading, "Truman Administration and Foreign Affairs" and is in the context of its strategic value in the Cold War. The statehood of Israel is mentioned in the context of Britain's decline in the Middle Eastthe wording is unchanged from the 1967 edition, even to the "mixed reaction" of the U.S. toward Israel's independence.

(HM 1986) First mention of Israel is found under the heading, "How Did President Eisenhower Meet the Problems of the Cold War?" and "A Crisis Arises in the Middle east” (p. 676). The Middle East is described as being, “...the chief danger spot for world peace" during Eisenhower's term, and the establishment of Israel is summarized in the following statement: "After World War II the state of Israel had been established as a Jewish homeland. But Arab countries in the Middle East refused to accept Israel's right to exist and threatened to destroy the new nation. This situation gave the Soviet Union an opportunity to increase its influence in the Middle East by offering aid to Israel's Arab neighbors" (p. 676). 
(Holt 1986) After a discussion about NATO and the American policy of containment by the end of 1949, tension in the Middle East is alluded to with the statement: "Meanwhile, trouble was brewing in the Middle East and in Asia” (p. 829). Further details about trouble in the Middle East are found under the heading "Growing nationalism and Communist aggression lead to war in Asia" (p. 830). The text simply explains that tensions between "Jews and Arabs" in Palestine caused trouble to break out.

(PH 1986) This text is arranged very differently from previous textbook and publishers' editions. While the peace treaty that President Carter helped to negotiate between Egypt and Israel is the textbook's first mention of Middle East affairs, it is only one sentence in a lengthy passage about President Carter's administration (p. 679). The text's entire history of conflict in the Middle East is included in section three of chapter thirty-one, entitled "Challenges to Peace" (p. 706). In the introduction to section three, the United States' difficult diplomatic position is immediately highlighted. Israel is identified as a U.S. ally, but the Middle East's strategic location and oil reserves are also given as reasons why the U.S. desires to maintain ties with "Arab states that oppose Israel" (p. 706). The text identifies Israel as being "the center of controversy since it was set up as an independent nation in 1948” (p. 706).

(HM 1996) Israel's history from the mandate period first appears in a chapter on the 1970s about Ford and Carter, under the heading, "World Tensions Increase", and the subheading, "Crisis Follows in the Middle East" (p. 913). Oil and concern over Soviet expansion, according to the text, were the United States' primary reasons for involvement in the Middle East after World War II. As an introduction to the Camp David Accords, the mandate period is summarized. 
(Holt 1995) While Israel is not mentioned specifically, this text summarizes the mandate system in the context of a discussion on the Treaty of Versailles (p. 608). To end discussion on World War I, the text goes a step further under the subheading, "The Global Impact of the War" (p. 610). The text states: "In the Middle East, Arab nations...found themselves living under French and British mandates. Tensions in the region heightened after Britain issued the Balfour Declaration in 1917, declaring British support for a Jewish homeland in Palestine" (p. 611). The Balfour Declaration is even included in the section review, along with the mandate system. More in-depth information on Israel and Middle East tensions is found in a special section of the chapter entitled, "The Postwar Years". The one focus question at the top of the page dealing with the Middle East states: "Why did Israel and Arab nations go to war" (p. 796)? Cold War concerns in China and Korea were also included in this section.

(PH 1995) The 1948 War is in the context of a chapter entitled, "The Cold War and American Society", under the subheading, "the Middle East" (p. 731). American oil interests and concern over Soviet expansion were given as the main reasons for U.S. involvement in the region..

(HM 2003) The first mention of Israel appears in Chapter 26 entitled, "Cold War Conflicts" (p. 831). A special "World Stage" text box of three sentences summarizes Israel's beginnings, and is meant to provide context for the text's two paragraphs on the Suez War.

(Holt 2003) This text is much the same as the last edition in context. First mention of the Balfour Declaration is under the heading, "The Global Impact of War", in a chapter 
on World War I. The text explains that the mandates, along with the Balfour Declaration, were growing sources of tension in the region (p. 653). A whole section entitled, "The Founding of Israel", appears in a chapter on the Cold War. The main body of text is surrounded by a special textbox on "American Judaism", and a picture of three Jewish immigrants arriving in Palestine, holding an Israeli flag (p. 837). The underlying problem is conflict between Jews and Arabs over the land.

(PH 2005) Israel's history of and prior to 1948 appears in a chapter on the Cold War, under the subheading, "The Middle East" (p. 891). The book provides no context for underlying problems in the region, except to say that there were "historic tensions".

\section{What theories provide the descriptions and explanations thought relevant?}

(Holt 1950) In describing the diplomatic position of the United States toward Israel in 1948, points out that many Americans, "sympathized with the Jews who were fighting to protect the independence of their newly created state of Israel", but also points out the desire of the United States for "friendly relations with the Arabs, who controlled vast oil deposits in Saudi Arabia" (p. 816). It is interesting to note that the text does not point out why Israel needed to defend itself, and from whom specifically.

(PH 1957) This text describes the "restless Arab peoples [and] Arab nationalism" as threatening American, British, and French oil interests, as well as access to the Suez Canal. The dilemma America faced between supporting its old allies, and undermining NATO by sympathizing with Arab nationalists is highlighted, with the conclusion that, "American policy tended steadily to favor the Arab states" (pg. 753). 
(PH 1967) The Middle East is mentioned because of its "strategic" location between Southeast Asia Treaty Organization (SEATO) countries of the Far East and North American Treaty Organization (NATO) countries of the West.

(HM 1975) It is interesting to note that this text places the primary responsibility for the creation of the state of Israel on President Truman's shoulders, stating: "President Truman had taken the lead in helping to establish the state of Israel as a homeland for the millions of European Jews who had survived the persecutions and fightings of World War II" (p. 697). Assumptions implicit in this statement are that Israel was established by cooperating western powers that sympathized with European Jews after World War II. (Holt 1977) This text implies that Israel was declared a state because Great Britain gave up its mandate. Interestingly, a caption picturing Dr. Bunche receiving his Nobel Prize states that Dr. Bunche, “... arranged an armistice ending the Palestinian War” (p. 685). (PH 1977) Widespread sympathy for Israel among Jewish urban voters is cited by the text as the reason why the U.S. did not join the Middle East Treaty Organization (METO) in 1955.

(HM 1986) Israel's establishment, according to this text, was to provide a homeland for the Jewish people. Precipitating causes other than a homeland are not stated. (Holt 1986) The text explains that Great Britain had ruled Palestine under a mandate from the League of Nations since the end of World War I. Great Britain's voluntary acquiescence to the UN of their mandate in Palestine is seen as the cause for Jews in Palestine claiming independence for Israel. 
(PH 1986) Specific dates (1929-1948) for Britain's mandate period in Palestine are identified, and the text states: "The British allowed Jews to settle there in part because Palestine was the home of the Jews in ancient times. In the 1930s, many Jews fled from Hitler's Germany to live in Palestine" (p. 706). World War II is also cited as the impetus that caused "...Jews from around the world [to flock] to Palestine" (p. 706).

(HM 1996) It is interesting to note that this text states: "In 1948 Britain ended its mandate, and the republic of Israel was proclaimed by the United Nations" (p. 914). (Holt 1995) This text is unique in that it gives a reason for why Great Britain gave up its mandate, stating: "Unable to resolve conflicting claims over territory, Britain in 1947 turned the problem over to the United Nations" (p. 796). The text even explains the UN Partition Plan to divide Palestine into two states, and mentions that, “...Arabs rejected the proposal" (p. 796). Much of the texts' explanations are also in the context of the Zionist movement and Ben-Gurion's leadership. Under a map of Israel in 1949, the caption states: "Success story: The memory of the Holocaust and the struggle to create a Jewish state unified the Israelis in a common cause" (p. 797).

(PH 1995) The strategic importance of the Middle East for the U.S., and Jewish immigration to Palestine for the Zionists are the main causes of tension, according to this textbook.

(HM 2003) This text does not give a lot of description or explanation regarding Israel's independence, except to say: "The creation of Israel was one of the few issues upon which the United States and the Soviet Union agreed, as the world reacted uniformly to the horror that had befallen the Jews in the Holocaust" (p. 831). Sympathy for Jews 
surviving the Holocaust was the primary motivation for the creation of Israel, according to this text.

(Holt 2003) Zionism is defined and explained in the text's section on the founding of Israel, along with Ben-Gurion's leadership of the movement. Zionism, combined with support from the American Jewish community is seen as the impetus for the creation of the state of Israel. Arab protest against Jewish immigration and the UN partition plan is crystallized in their response to Israel's declaration of statehood.

(PH 2005) Jewish immigration to Palestine prompted by the Holocaust is seen as the impetus for intensifying demand for Jewish homeland, although the Zionist movement is never mentioned specifically.

\section{What relationships, causes, consequences are proposed?}

(Holt 1950) This text includes a friendly, relaxed picture of Dr. Ralph Bunche and Israeli Prime Minister David Ben Gurion. No date for the picture is given, but in the context of the textbook's section on the UN, a student could reasonably assume the picture was taken during peace negotiations, but is left to wonder with whom Israel may have been negotiating. Interestingly, Dr. Bunche is highlighted in the picture caption as having helped to "avert war between the new nation of Israel and the neighboring Arab state" (p. 804). What Arab state is being spoken of is not in the text, and from the caption, students might incorrectly assume that war was averted entirely.

(PH 1957) This text is unique among the 1950s texts, in that it highlights some of the causes of antagonism between Israel and the Arab states; the 1917 Balfour Declaration, and its promise to provide a homeland in Palestine for the Jewish people, is cited among those causes. The Arab League, its refusal to accept Israel as a new state, and its vow to 
destroy Israel are also cited as causes of intermittent war and "an uneasy truce" between the two sides (p. 753).

(1966 Holt) The textbook cites Israel's declaration of statehood as the immediate cause that, "plunged Israel into war with the neighboring Arab countries of Egypt, Transjordan, Lebanon, Syria, Iraq, and Saudi Arabia" (p. 773). A map of "Critical Areas in the World After 1945" included the Middle East and its 1948 "Israeli/Arab War" (p. 784). U.N. efforts to end the fighting are acknowledged in the, "leadership of Dr. Ralph J. Bunche [who] managed to get both sides to agree to an armistice" (p. 773). In the $1967 \mathrm{PH}$ textbook, Great Britain's relinquishment of Jordan and Palestine is seen as the cause of independence in both countries, and the consequence is the hastening of Britain's "decline in the Middle East" (p. 815). A consequence of Israel's statehood as mentioned in the text, is the inflaming of Arab nationalism and setting the stage in Egypt for Nasser to take power, with his "ambitions to unite the neighboring Arab lands" (p. 838).

(HM 1975) A consequence of "American aid and friendship to Israel", according to the text, was the continued displeasure of the Arab states, who, “...fought an unsuccessful war against Israel [and] refused to accept its right to exist, and continually threatened to destroy it" (p. 697). The ultimate consequence of this situation, according to the text, was the opportunity for the Soviet Union to exploit the unrest and increase its influence in the Middle East.

(Holt 1977) The consequence of Israel's independence"plunged Israel into war with the neighboring Arab countries of Egypt, Transjordan, Lebanon, Syria, Iraq, and Saudi Arabia" (p. 684). Dr. Bunche's efforts to achieve peace are highlighted, and the only 
indication that it was a long and difficult process is the word, "finally", in the statement, "Finally a UN mission...managed to get both sides to agree to an armistice" (p. 684). (PH 1977) The text states that the Arab powers in METO, “...had sworn to destroy the Jewish state" (p. 655).

(HM 1986) The consequence of Israel's establishment, according to this text, is clearly the hatred of the Arab nations.

(Holt 1986) Israel's declaration of statehood earned them Arab hatred and resulted in war. The text notes that the UN took immediate action to end the fighting, and particularly highlights Dr. Ralph Bunche's efforts in “manag[ing] to get both sides to agree to an armistice" (p. 831). This text is unusual in that it notes in the caption under a picture of Dr. Bunche that his predecessor was assassinated for similar efforts (p. 831). The text notes that the armistice was an "uneasy peace". Students are asked in a section review question to, "Describe the postwar events that created tension in the Middle East" (p. 835).

(PH 1986) Jewish settlement in Palestine is cited by the text as the cause of Arab resentment, only made worse in 1948, when, “...Jewish residents of Palestine announced that they were setting up the State of Israel” (p. 706).

(HM 1996) After Israel became a state, this text explains why Arab states were angered: "They [Arabs] claimed the nation had been created out of land that belonged to the Arabs" (p. 914). The consequence in the text were the four wars fought between Israel and "Arab nations", and the text also points out that most of the Arab "manpower and weaponry" came from Egypt. 
(Holt 1995) Ben-Gurion's leadership of the Zionist movement, in this text, was instrumental in Israel's independence. This text, unlike others, states: "Ben-Gurion and other Jewish leaders promptly proclaimed the new state of Israel” (p. 797). It also recognized that the U.S. and Soviet Union extended immediate diplomatic recognition. Arab states' refusal to recognize Israel, according to this text, stemmed from their desire to keep Palestine in Arab territory. The attack on Israel by five Arab states (which are listed) was the consequence, and again, Ben-Gurion was instrumental in capturing and holding much of Palestine, until "the millions of dollars that poured in from the American Jewish community", sustained the Israeli soldiers and the war effort (p. 797). This text also goes into more detail than others, on the peace process after the 1948 war. Explaining that "Israeli extremists" assassinated the first UN mediator, the text also explains that even after the armistice, Arab states still refused to recognize Israel. Also the first to delve into the issue of Arab refugees, the text states: "Also left unresolved was the fate of the Arabs remaining in Israel and the hundreds of thousands of Arabs who had fled or been driven out of Israel” (p. 797).

(PH 1995) It is interesting to note that this text identifies the UN as the creator of Israel: "Tensions between Palestinian Jews and Arabs erupted with the UN announcement of the new Jewish state, called Israel, on May 14, 1948” (p. 731). Immediate diplomatic recognition on the part of the U.S. and Soviet Union is mentioned, as is the immediate invasion of Israel by Arab countries. The book declares that, "Israel defeated those states and annexed most of the Palestinian territory as shown on the map on page 732." U.S. sympathy for Israel along with interest in Arab oil, ends the discussion on the Middle East. 
(HM 2003) Jewish immigration to Palestine before and after World War II, along with world sympathy for survivors of the Holocaust, are seen as causes leading to the creation of Israel as an independent state. The text highlights U.S. and Soviet agreement regarding Israel, and identifies the UN Partition Plan as responsible for the Israel's independence.

(Holt 2003) The relationship between Zionism and the American Jewish community, along with the hatred of the Arab world, are clear in this text. Ben-Gurion's dedication to the Zionist movement, along with American support, resulted in its eventual success in the new state of Israel. The consequence of this success was war with the surrounding Arab states.

(PH 2005) British inability to meet the demand for a Jewish homeland caused them to turn the question over to the UN. The text acknowledges "historic tensions" in the region, but does not provide specific information on the sources of those tensions. The claim to Palestine as an ancient homeland by both Jews and Arabs is seen as the main source of conflict. Interestingly, the text does acknowledge that Palestine was "...the Biblical home of the Jewish people..." (p. 891). The consequence of these conflicting claims was an attack on Israel by its "Arab neighbors", a successful defense by Israel, and newly mediated borders by the UN. Another consequence included in a caption above a map of Israel after the 1948 War was Egypt's blockade of the Suez Canal of any ships going to or from Israel.

\section{On what premises is the account based and what assumptions are made in the course of the explanation (Larsen, 1991)?}


(Holt 1950) This text assumes that most Americans sympathized with the Jews defending Israel. The most thorough text on this topic is undoubtedly the $1957 \mathrm{PH}$ text. It is interesting to note that in discussing the "uneasy truce" between Israel and the Arab League after 1948, the text states that the Arab League accepted a truce, “...not because they were reconciled to Israel's existence but because they had been unable to subdue her" (p. 754). Again, the dilemma of U.S. policy toward Israel is highlighted, with American sympathy for Jewish refugees after World War II on the one hand, and the desire for friendly relations with Arab nations on the other hand.

(PH 1957) This text reinforces that the Arab nations harbored an "implacable hostility" against the state of Israel, but also implies that a common statement made by the U.S., Britain, and France in 1950 about weapons sales to Israel and the Arab states, along with a pledge to take action against aggression by either side, was a success in assuring peace in the region (p. 754).

(1966 Holt) The text ends discussion on the Middle East by stating that an, "uneasy peace" had been restored (p. 773). The one review question on the Middle East asks, "What were the events that created tension during the postwar years?" The only two conclusions students would be able to come to, based on the text, is that tension was created by Israel's declaration of statehood, as well as the remaining Soviet forces in Iran (p. 773).

(HM 1975) The end of chapter review questions simply states: "What events in the Middle east threatened world peace" (p. 699)? 
(Holt 1977) Students are asked in the section survey to, "Describe the postwar events that created tension in the Middle East" (p. 687). According to the text, one of the only two answers would be Israel's declaration of statehood.

(PH 1977) U.S. politics and the perceived powerful influences of Jewish urban voters color this texts' interpretation of U.S. relations with Israel.

(HM 1986) The importance of the Middle East is still seen in the context of the opportunities it presents for the U.S. and the Soviet Union. The only two review questions, one for the chapter and one for the unit, asked what events in the Middle East and what trouble spots threatened world peace during President Eisenhower's term. (Holt 1986) This texts' account of the Middle East is borne out of its discussion on nationalism and a main concern about events in Asia, particularly China and Korea. The Middle East is seen as a peripheral problem and strategic only for stemming the tide of growing Soviet influence.

(PH 1986) Worldwide Jewish emigration and Arab hatred of Jewish immigrants to Palestine is the premise for this text's account of early conflict in the Middle East. The Arab nations' refusal to recognize Israel as a legitimate state is the motivation for their attack on Israel. Going a step further than any other textbook thus far, the closing sentences of Israel's period of independence state: "Israel successfully defended itself and even added to its lands. After 1948, about 700,000 Arabs fled Palestine. They gathered in refugee camps in Jordan, Lebanon, and Syria" (p. 706).

(HM 1996) One major assumption is that the United Nations proclaimed Israel a nation. Another problem is that the book states: "As you know, between 1948 and 1973, four wars were fought between Arab nations and Israel" (p. 914), but aside from the mention 
of the 1948 war in the previous statement, it is not mentioned elsewhere. The 1967 Six Day War is only included on a timeline at the beginning of the chapter. This texts' whole account is based on a premise of eventual peace, with the Camp David Accords as the climax. It also highlighted the United States' difficult diplomatic position between supporting Israel and finding a solution "to the Palestinian issue" (p. 914).

(Holt 1995) Undoubtedly, the premise for war, according to this text, was over the territory of Palestine itself. One statement in this text, which could be considered by some scholars as an assumption and by others as fact, was: "Although vastly outnumbered in the Arab-Israeli war, Israeli forces...captured and held much of Palestine" (p. 797).

(PH 1995) The premise of this text's account is clearly in the context of the Cold War and American oil interests in the region. The major assumption in this passage is that Israel's defeat of the invading Arab nations negated any necessity for a peace process and left no unresolved issues in the region.

(HM 2003) This account is based on the assumption of worldwide sympathy for Jews after World War II. The text implies that the world was in agreement (“...as the world reacted uniformly") about the horrors of the Holocaust, and by extension, the Jews' need for a homeland. The text also implies that Jews had never lived in a "promised land", even in biblical times: "Thousands of Jews had immigrated to Palestine from Europe before and during World War II, and Israel became the 'promised land' they had been seeking since biblical times" (p. 831). Students could be left with the impression that Jews had never been or continued to be residents of Palestine since biblical times. 
(Holt 2003) The whole premise of this passage is the founding of Israel. One possible assumption that remains from the last edition was that Israel was "vastly outnumbered" in the 1948 war (p. 837). The most important information in this passage, as identified by the section review questions are: "What events led the UN to try to resolve the conflict over Jewish and Arab claims to Palestine? [and] How successful was the effort?" (PH 2005) The premise of this account is the Cold War, along with conflicting Jewish and Arab claims in Palestine. A major assumption in the text includes students' prior knowledge of "historic tensions" in the region.

\section{What perspectives, questions, theories are not acknowledged (Larsen, 1991)?}

(Holt 1950) In a paragraph on tensions in the Middle East, the text simply states there was an outbreak of war between Arabs and Jews in Palestine. Causes of the outbreak are not acknowledged, and the conflict is seen in the light of the threat it presented to United States oil interests in the Middle East. Holt states that the conflict was "finally resolved by a United Nations mission under the leadership of an American, Dr. Ralph Bunche, who took the job of mediator after his predecessor, Count Folke Bernadotte, had been murdered late in 1948” (p. 816). The preceding statement gives the impression that no issues of contention remained after negotiations, and fails to address why Bunches' predecessor was assassinated.

(PH 1957) This text, although acknowledging the promises of a Jewish homeland made in the Balfour Declaration, and the hostility of the Arab League toward Israel's existence, does not give details about what prompted the Jews' desire for a national homeland and why the establishment of Israel angered Arab nations. Competing promises made to both sides by the British during the mandate period are not acknowledged. Most importantly, 
the text does not address the unresolved issues of the 1948 war over Arab refugees and does not explicitly mention the Arab League's refusal to acknowledge the legitimacy of the new state of Israel, thereby hampering direct negotiations. There are no timelines, pictures, or maps that picture exactly what territory was involved.

(1966 Holt) The text does not answer why Great Britain "voluntarily" gave up their mandate in Palestine, and does not put Israel's declaration of statehood in any kind of context. While Bunche's peace negotiations, and Nobel Peace Prize, are acknowledged, the fact that his predecessor was assassinated for similar efforts is not mentioned. The text simply states that an "uneasy peace" was restored through Bunche's efforts, but does not say what the points of negotiation were and what issues were left unresolved. (PH 1967) The text does not acknowledge why Britain agreed to Jordan's independence or why Palestine was turned over to the U.N. It also leave unsaid why U.S. reactions to the new state of Israel were "mixed" (p. 815). The 1948 war resulting from Israel's declaration of statehood is not addressed.

(HM 1975) This text does not answer why President Truman "took the lead" in establishing the state of Israel, other than to imply he also felt sympathy for survivors of the Holocaust. The text also leaves out why the Arab nations fought in a war against Israel and why they "continually threatened to destroy it" (p. 697). Also left unsaid are which Arab states were part of this continued Arab threat.

(Holt 1977) Left unsaid in this text are reasons why Britain gave up its mandate, why Israel declared statehood, why Arab nations reacted by going to war, and how America reacted to these changes. Also not included are details of the peace negotiations, the fact 
that Bunche's predecessor was assassinated, and what issues were left unresolved, even after an "uneasy" peace was restored.

(PH 1977) Familiar questions are left unanswered in this text as well, including why Britain turned over its mandate to the UN, why Israel declared independence, and why Arab nations were "inflamed" by the creation of Israel (p. 654). The 1948 war that resulted from Israel's declaration, and ensuing peace negotiations are entirely absent.

(HM 1986) The following questions are left unanswered by this text: Why was the Middle East the "chief danger spot for world peace" during Eishenhower's term? Why did Jews need a homeland? Why did Arab nations refuse to acknowledge Israel and want to destroy it?

(Holt 1986) U.S. feelings about the establishment of Israel are not acknowledged and neither are reasons for tensions between Jews and Arabs in Palestine. While the text is specific about which Arab nations were "angered" by Israel's establishment, the text reduces the fact that these nations went to war in 1948, with the simple statement that "trouble broke out" (p. 831). The passage does nothing to explain what the causes were, and fails to give any detail about armistice negotiations and issues left unresolved. (PH 1986) U.S. reaction, aside from officially recognizing Israel as a state, is not addressed in this text. It is also interesting to note that the text statement, "The British allowed Jews to settle..." implies that there were none living in Palestine after ancient times and prior to the mandate period. It also does not mention that many Jews were denied entrance to Palestine when fleeing Hitler and even into the mandate period. Britain's voluntary ending of the mandate period as well as the armistice negotiations to end the 1948 are completely absent. While the book does well to mention Arab refugees 
after 1948, Jewish refugees from Arab countries are not mentioned. The fact that the refugees became a main source of contention between Jews and Arabs is not mentioned either. In spite of these shortcomings about the mandate period and 1948 War, this text provides the most complete picture thus far of the establishment of Israel and on of the main sources of contention between Arabs and Jews - the land itself.

(HM 1996) Familiar unanswered questions include: Why did Great Britain give up its mandate? What was the impetus for Israel's statehood? Why did Egypt supply the Arab world with weaponry and, financially, how could they? While Arab reaction to the state of Israel is included in the text, Jewish and American reactions to the developments in the Middle East are not.

(Holt 1995) The most detailed account thus far, this text still conspicuously avoids a conclusive statement on whether Arab refugees fled or were driven out of Israel prior to 1948. It does not mention at all, Jewish refugees from Arab lands. Nonetheless, this text does the most complete job so far, on endeavoring to present both sides of the conflict. A special text box on the "Arab response" to the 1948 War is included, with a lengthy quote from Musa Alami, a contemporary of the 1948 War, and an Arab lawyer and diplomat. Interestingly, the text introduction states that Alami was a promoter of "Palestinian nationalism and unity", but the quote from Alami only addresses Arab unity and the land of Palestine itself (p. 798).

(PH 1995) This text leaves many unanswered questions, in large part, because it does not begin a history of the region until the 1947 UN Partition Plan. Causes of the UN Partition Plan are totally left out, as is any mention of the mandate period. Although the Zionist desire for a Jewish homeland is mentioned, the text implies that the only problem 
in achieving this desire, was a lack of Jewish immigration to Palestine. “...it was not until World War II, when thousands of European Jews immigrated to the region, that the Jewish population was large enough to form a new state" (p. 731). Arab, American, and Jewish reactions to the creation of Israel are also excluded, except for the statement that tensions "erupted" with the announcement of Israel's statehood.

(HM 2003) This text leaves much to be desired. Aside from including the date of Israel's independence, this text addresses nothing regarding Israel's perspective, Arab response, and American involvement in the events leading up to 1948, and after.

(Holt 2003) This text offers the most complete picture of the events leading up to and immediately following 1948. The major question left unanswered is why Arab countries refused to recognize Israel even after the 1949 agreement. The book does state that the

“...fate of Palestinian Arabs remaining in Israel" was left unresolved, but implies that this issue was separate from Arab states refusing to recognize Israel (p. 837).

(PH 2005) "Historic tensions" in the region are not specifically addressed. The text does not identify where calls for a Jewish state were coming from, only that they "intensified" with Jewish immigration to Palestine after the Holocaust. The UN mediation process is not discussed and neither are unresolved issues after the 1948 war. The text simply states: "Arab hostility to the idea of a Jewish state continued..." (p. 891).

\section{Suez Canal Crisis:}

\section{1. "What are the underlying problems which have generated this discourse"}

\section{(Larsen, 1991)?}

(PH 1957) For having a copyright date of 1957, this text is surprisingly detailed in its account of the 1956 Suez War. The underlying problems generating discussion of the 
conflict are the tripartite agreement between Great Britain, France and the U.S. to supply arms to Israel and Arab states, only with assurances that the arms would not be used for aggression toward other countries. Growing tensions with Egypt also provide context for discussion of the 1956 war.

(HM 1962) "Rising Egyptian nationalism" and the withdrawal of British troops from the Canal Zone, are seen in this text as the impetus in creating conditions favorable for unrest. This text is also very detailed in its account of the Suez War. Underlying problems include Nasser seeking financial backing from western and Soviet sources, along with his nationalization of the canal.

(Holt 1966) The major underlying problem which generates this text's discussion of the Suez War specifically is ownership, use, operation and protection of the Suez Canal. The text provides a detailed history of the building of the canal and the international treaty guaranteeing its international status and protection by the British. In general, the underlying problem is increasing discontent in the Middle East toward western powers, addressed specifically in the textbook in a post-Suez war paragraph about the United Arab Republic's formation, with Nasser as its president, and widespread support from communists in Arab nations. The Eisenhower Doctrine is highlighted as the response to such unrest, and in order to "[fill] the vacuum left by the decline of British and French power and influence" (p. 780).

(PH 1967) Putting the 1956 war in context is this text's preceding statement on METO (Middle East Treaty Organization) and Nasser's decision to stay out of the organization: "Nasser resented the inclusion of Iraq, a fellow Arab state which preferred American aid 
to Arab unity. He [Nasser] also wished freedom of action in playing off the U.S.S.R. and the West against one another to Egypt's national advantage" (p. 838).

(HM 1975) The underlying problem in this text is clearly the Soviet Union's attempts to gain a foothold in the Middle East. Soviet financing of the Aswan Dam is given as an example of these efforts.

(Holt 1977) With the exception of some grammatical changes and a picture of the Aswan dam rather than UN troops stationed along the Suez Canal cease-fire line, this text is identical to the the 1966 edition. The major underlying problem which generates this text's discussion of the Suez War specifically is ownership, use, operation and protection of the Suez Canal. The text provides a detailed history of the building of the canal and the international treaty guaranteeing its international status and protection by the British. In general, the underlying problem is increasing discontent in the Middle East toward western powers, addressed specifically the textbook in a post-Suez war paragraph about the United Arab Republic's formation, with Nasser as its president, and widespread support from communists in Arab nations. The Eisenhower Doctrine is highlighted as the response to such unrest.

(PH 1976) The underlying problem in this text is the competing agendas between the Soviet Union and the United States regarding the Middle East. Egypt's refusal to join METO (Middle East Treaty Organization) stemmed from its desire, according to the text, to have, "...freedom of action in playing off the USSR and the West against each other" (p. 655).

(HM 1986) This text's account is very trimmed down in comparison to all of the other texts thus far, although it does have some significant changes. The underlying problems 
are, like always, the tensions of the Cold War, with the Middle East being labeled a "danger spot" in the conflict (p. 676).

(Holt 1986) This edition is very similar to the previous two Holt editions, with one primary difference. For the first time, this text mentions that Nasser's nationalization of the Suez Canal concerned western Europe because it affected the free flow of oil from the Middle East. This is the first text to mention concerns about oil, along with concerns about the balance of power in the region and between NATO and Soviet Union nations during the Cold War. The account of the Suez War, like all other texts studied thus far, still appears within a section titled, "The United States Continues to Meet the Challenges of Communism" (p. 835).

(PH 1986) Although this text has a section entitled, "Search for Peace in the Middle East" within a chapter on "Challenges to Peace; 1960 to Present" (also including Cold War rivalries, Southeast Asia, and America's neighbors), this text mentions nothing of the Suez War in its short history of "Conflict Over Israel".

(HM 1996) The Suez Canal crisis appears in this text, under the heading, "The Cold War Spreads Eastward" (p. 808). (It is interesting to note that any historical context regarding Israel appears later in the book, when Camp David is discussed. So a student reading chronologically would have no framework for understanding the historic tensions between Egypt and Israel at the time of the Suez Canal crisis.)

(Holt 1995) The major underlying problem in this textbook involved the question of who would have the greater influence in the Middle East—-the U.S. or the Soviet Union. A secondary problem related to this was Nasser seeking financing from the U.S., Britain, and the Soviet Union for the Aswan Dam. 
(PH 1995) Although this text has a chapter entitled, "The Cold War and American Society 1945-1960" (and the timeline includes the 1956 uprising in Hungary) this text mentions nothing of the Suez War in its short history of "The Middle East" (p. 731). (HM 2003) This text's brief account of the Suez War appears in the chapter titled, "Cold War Conflicts" and in the section, "Two Nations on the Edge". While the account is told within a Cold War context, the rivalry between the Soviet Union and the United States for influence in the Middle East is actually downplayed in this text's short history of the Suez War. The main problem seems to be control of the Suez Canal itself, and from the text, it appears that Britain and France were really the countries that were most concerned and Egypt's nationalization of the canal.

(Holt 2003) This text's account of the Suez War appears in a chapter titled, "The Cold War" and section subtitled, "The Cold War Turns Hot" (p. 844). The underlying problem seems to be fighting communism abroad, although that is not readily apparent until the last two sentences when the text mentions the enhanced influence of the Soviet Union in the Middle East after the Suez War, and the American response with the Eisenhower Doctrine. Until then, a primary underlying problem is hard to find and this text's too concise account seems to string together events, mostly without a historical or diplomatic context.

(PH 2005) The underlying problem in this text is found in the following opening statement to explain events in the Middle East, after the founding of Israel: "Meanwhile, the United States also worked to prevent oil-rich Arab nations from falling under the influence of the Soviet Union" (p. 891). The free flow of oil, and the effects Communism would have on that, seems to be the predominant concern in this text. 


\section{What theories provide the descriptions and explanations thought relevant?}

(PH 1957) The 1955 Egyptian arms deal with the Soviet Union, "continuing antiWestern gestures", Dulles' canceling of American support for the Aswan dam, and Nasser's nationalization of the Suez Canal are all reasons the text cites in leading up to the war (p. 754).

(HM 1962) Nasser's bargaining with the Soviets is seen as the reason why the United States pulled funding from the Aswan Dam project, just as Nasser was willing to accept U.S. conditions. Israel's motivations for going to war, according to this text, include: Egypt's continued refusal to extend diplomatic recognition, its closing of the canal to Israeli shipping, and Egypt's vow "to drive Israel into the sea" (p. 780). Great Britain and Frances' motivations were seen as protecting their interests in the Suez Canal. (Holt 1966) This text implies that Nasser's nationalization of the Suez Canal was revenge for the U.S. withdrawing its offer to finance the Aswan Dam. Israel's invasion of the Suez Canal is seen as igniting an already tense situation, and the reason for Israel's invasion, as stated in the text: "The Israeli government announced that its troops had invaded Egyptian territory in order to forestall a carefully planned attack upon Israel by Egypt” (p. 780). The text does not propose any possible connection at all between Israel, France and England, and in fact, "western powers" are portrayed as trying very hard to persuade Nasser to agree to international use and control of the Canal Zone. Egypt's refusal of international control, and to a cease fire with Israel, is seen in the text as the impetus for France and England's invasion of the Canal Zone, and for the U.S. diplomatic embarrassment of having to go against its NATO allies in the United Nations when voting for a cease-fire and withdrawal of British, French, and Israeli troops. 
(PH 1967) This text begins specific discussion of the Suez crisis by stating, in 1955: "Israeli forces invaded the Gaza strip, a contested area on their Egyptian border. Nasser's difficulty in dislodging them underscored his military weakness..." (p. 839). This military weakness is seen as the impetus for Egypt's arms build up and deal with Russia, and Israel's bid to the U.S. for a similar arms deal.

(HM 1975) Theories and descriptions in this text are very general. The account simply begins with the statement: "The crisis developed in 1956 when Egypt took over the Suez Canal...” (p. 697), which according to this text is the major impetus for the 1956 war. (Holt 1977) This text implies that Nasser's nationalization of the Suez Canal was revenge for the U.S. withdrawing its offer to finance the Aswan Dam. Israel's invasion of the Suez Canal is seen as igniting an already tense situation, and the reason for Israel's invasion, as stated in the text: "The Israeli government announced that its troops had invaded Egyptian territory to forestall a carefully planned attack upon Israel by Egypt" (p. 689). The text does not propose any possible connection at all between Israel, France and England, and in fact, "western powers" are portrayed as trying very hard to persuade Nasser to agree to international use and control of the Canal Zone. Egypt's refusal of international control, and to a cease fire with Israel, is seen in the text as the impetus for France and England's invasion of the Canal Zone, and for the U.S. diplomatic embarrassment of having to go against its NATO allies in the United Nations when voting for a cease-fire and withdrawal of British, French, and Israeli troops.

(PH 1976) This text presents a theory about why the U.S. did not join METO: "Widespread sympathy for Israel, especially among Jews, who contributed heavily to the urban vote, constrained the administration from appearing to huddle too closely with 
Arab powers, who had sworn to destroy the Jewish state" (p. 655). Undoubtedly, the Cold War is the most prominent theory providing descriptions and explanations throughout. The U.S. withdrawal of financial aid for the Aswan Dam, in this text, is due to Nasser's "anti-Western gestures" (p. 655). Nasser's nationalization of the canal is in retaliation to this U.S. decision.

(HM 1986) The predominant theory that underlies this text's explanation of the Suez War is Nasser's action to "[take] over the Suez Canal and [close] the waterway to Israeli shipping" (p. 676). The second part of this statement mentioning Israeli shipping is a significant change from previous editions and publishers, since most often this aspect of Nasser's nationalization of the canal was not mentioned.

(Holt 1986) Increasing Egyptian dissatisfaction with British military occupation around the Canal Zone after World War II is given as the reason why the British evacuated the area in 1956. Nasser's goals to modernize Egypt and "extend Egyptian influence throughout the Middle East" are given as reasons why Nasser wanted to build the Aswan Dam. Nasser's nationalization of the Suez Canal is seen in this text as revenge for U.S., British, and Soviet refusals to finance the Aswan Dam. Israel's attack on Egypt is seen as a preemptive strike to prevent a "planned attack upon Israel by Egypt" (p. 839). Britain and France's cause for invasion, according to this text, was over Egypt and Israel's refusing to agree to a cease-fire and to allow the French and the British to occupy "key points in the Canal Zone" (p. 839). U.S. intervention was done primarily to avoid the appearance that the Soviet Union, "was the only champion of Egypt and other small nations against 'Western imperialism'” (p. 839).

(PH 1986) N/A 
(HM 1996) The predominant theory prompting all other actions in this textbook is found in the statement: "In 1955 Great Britain and the United States, eager to keep Soviet influence out of Egypt, agreed to help finance construction of the Aswan Dam on the Nile River" (p. 809). All explanation that follows stems from this statement and resulting decisions on the part of Egypt, the Soviet Union, and the U.S. (and by extension France, Britain, and Israel).

(Holt 1995) The most prominent theory underlying this texts' explanations was the U.S. financing of Aswan as a means to influence foreign policy (although what foreign policy exactly is not mentioned),

(PH 1995) N/A

(HM 2003) The predominant theory in this text seems to be that the United States was not going to play Nasser's game of competing with the Soviet Union, and consequent choices on all sides stem from this diplomatic decision.

(Holt 2003) The predominant theory of this text's account can be found in the following opening statement to the Suez War: "In some cases, Eisenhower used diplomacy rather than covert actions to influence foreign policy" (p. 849). Exactly what Eisenhower was trying to influence or whom is, unfortunately, not very clear in this text. (PH 2005) This text opens discussion on the Suez War by explaining that Nasser was seeking Soviet support. What he was seeking support for is not mentioned, but this decision on the part of Nasser is the impetus for all other explanation of the Suez War. This text states that Britain and France attacked Egypt to "regain control" of the canal (p. 891).

\section{What relationships, causes, consequences are proposed?}


(PH 1957) America's strained relationship with Egypt is highlighted; along with "possib[le]" collusion between Britain, France, and Israel in coordinating an attack on Egypt are cited (p. 754). Causes for the war include Egypt's continued drift toward Soviet influence along with the 1955 arms deal, Nasser's nationalization of the Suez Canal, and for Israel, “...destroying the bases from which a number of provocative Egyptian raids had been made on Israeli territory" (p. 754). One consequence of the war, according to this text, was British and French political and economic upheaval. The primary result was: "The Egyptians had learned how successfully they could play off the ambitions of Russia against the western powers. And the western alliance had been profoundly shaken" (p. 754).

(HM 1962) Russia, the United States, and the United Nations are seen as acting separately to pressure Britain, France, and Israel into a cease-fire. Egypt and Israel's refusal to pull back their forces from the canal area are given as the cause for Britain and France's involvement. Nasser's ambitions to "extend his power into other Arab countries" through formation of the UAR (United Arab Republic) is mentioned with postwar consequences. Expanding influence of the Soviet Union is also seen as a consequence of the unrest caused by the Suez War.

(Holt 1966) This text states that after World War II: “...the Egyptians became increasingly dissatisfied with British military occupation of the Canal Zone" (p. 780). Nasser's ambitions to "modernize the country, improve living standards, and extend Egyptian influence throughout the Middle East", according to this text, were the primary reasons Nasser wanted to build the Aswan Dam (p. 780). The United States' difficult diplomatic situation in voting against NATO allies, and in favor of a cease-fire between 
Britain, France, and Israel, is highlighted in the text because of U.S. fears that a failure to do so would confirm western imperialist fears in the Middle East and allow the Soviet Union, “...to claim that it was the only champion of Egypt and other small nations" (p. 780). It is also assumed that there was no connection or coordination between Israel, France, and Britain in the Suez War. The Eisenhower Doctrine is listed in the text as an “immediate result of the Suez crisis" (p. 780).

(PH 1967) America's diplomatic position, in relation to the arms build up between Egypt and Israel prior to 1956, is seen as a delicate one, hoping to "maintain Egyptian friendship", even amid Israeli requests for arms, which the U.S. "rebuffed" (p. 839). The breaking point for this hope of friendship, and cancellation of the United State's offer to finance the Aswan Dam, according to this text, was Egypt's "continuing anti-western gestures" (p. 840). Nasser's nationalization of the Suez Canal is seen as "retaliation" to these events. It is interesting to note that this text states: “...Israel launched an invasion of Egypt with the announced objective of destroying the bases from which Egyptian raids had been made on Israeli territory. This action was followed by a sudden Anglo-French invasion of the Suez area" (p. 840). U.S. response was one of "consternation" that they had to join with the Soviet Union in condemning their allies' use of force (p. 840). While the U.N. voted for a cease-fire, this text makes it clear that only the threat of "unilateral Soviet intervention" forced them to accept the U.N. vote (p. 840). The text states that it took "American and Soviet warnings" to get Israel to withdraw. The major consequences of the Suez Crisis, according to this text: "Nothing was solved in the Middle East by these steps and the Western alliance itself was badly shaken" (p. 840) The Eisenhower Doctrine is seen in this text as the direct response to the Suez Crisis and a "unilateral 
warning to the U.S.S.R. that the United States would defend the whole Middle East against Soviet attack" (p. 840).

(HM 1975) This text states that the war was between Egypt and Israel, but that France and Britain sided with Israel, implying that there was no premeditated planning between Britain, France and Israel. The text also points out that the U.S. and Soviet Union were "for once" on the same side of an international dispute (p. 697). The major consequence, according to this text, was continued U.S. suspicion of the Soviet Union, and the resulting Eisenhower Doctrine to stem the tide of Soviet influence in the Middle East.

(Holt 1977) This text states that after World War II: “...the Egyptians became increasingly dissatisfied with British military occupation of the Canal Zone” (p. 689). Nasser's ambitions to "modernize the country and extend Egyptian influence throughout the Middle East", according to this text, were the primary reasons Nasser wanted to build the Aswan Dam (p. 689). The United States' difficult diplomatic situation in voting against NATO allies, and in favor of a cease-fire between Britain, France, and Israel, is highlighted in the text because of U.S. fears that a failure to do so would confirm western imperialist fears in the Middle East and allow the Soviet Union, "...to claim that it was the only champion of Egypt and other small nations" (p. 690). It is also assumed that there was no connection or coordination between Israel, France, and Britain in the Suez War. The Eisenhower Doctrine is listed in the text as an "immediate result of the Suez crisis" (p. 690).

(PH 1976) Relationships in this text include the competition for influence in the Middle East between the U.S. and Russia, Nasser's 1955 arms deal with Russia and the "remarkable" collaboration between the U.S. and Russia in condemning the Anglo- 
French invasion of Egypt (p. 655). The ultimate cause of the war, according to this text was "the rising tension in the Middle East", and the consequence was Israel's invasion of Egypt. The Eisenhower Doctrine is also seen as the U.S. response to the Suez War. (HM 1986) This text is also one of the first to intimate diplomatic collusion between Israel, Britain and France. The book states that Nasser's closing of the canal to Israeli shipping led, “...in 1957, to a war in which Britain and France sided with Israel and attacked Egypt" (p. 676). It is stated that the United States and Soviet Union called for an end to the fighting, but this text places responsibility for the cease-fire on UN shoulders: "In time, the UN was able to establish a cease-fire and Israel, Britain, and France reluctantly withdrew their forces from Egypt” (p. 677). A major consequence, according to this text, was that the U.S. “...was still suspicious of what the Soviet Union might be planning in the Middle East" (p. 677). The Eisenhower Doctrine policies are mentioned as a final U.S. response, although the title "Eisenhower Doctrine" is not mentioned in the text, oddly enough.

(Holt 1986) Diplomatic relationships existing in this text, very similar to others, include: Egypt's dissatisfaction with British military occupation, Nasser's "furious" reaction to Soviet, British, and American refusals to finance the Aswan Dam, the Soviet Union's effective pressuring of Israel, France, and Britain to agree to a cease-fire, and the embarrassing American situation of siding with the Soviet Union against its NATO allies in condemning the attack on Egypt. The major consequence of the Suez War for American diplomacy was the Eisenhower Doctrine, which the book explains in detail. (PH 1986) N/A 
(HM 1996) Nasser, in this textbook, is painted as a leader with no ties to either East or West—-simply as a leader wanting to get the best deal on financing for the Aswan Dam. "Furious" about the withdrawal of financing from the West, Nasser's nationalization of the canal is seen as revenge for this decision. Like one text of the 1980s, this text mentions oil as a key reason for British and French involvement: "Now it was the turn of the British and French to be furious, especially since two-thirds of the oil they needed for heat and industrial production came through the canal" (p. 809). A rarity in other texts, this book also tries to present Israel's reason for involvement: "In the meantime, the Egyptians had been making raids into Israel. Also, since 1950, contrary to international law, Egypt had not allowed Israeli ships to use the canal" (p. 809). The previous two statements are tied together by the text in order explain why Israel, France, and Britain cooperated in their attack on Egypt. This assumption of collusion between the three nations is a newly emerging pattern in the textbooks, only really beginning in the 1980s. In fact, this text for the first time does not even mention France or Britain's call for a cease-fire between Israel and Egypt. While previous texts typically used the word "embarrassed" to describe U.S. reaction to its NATO allies' invasion of Egypt, this text uses the word "shocked", implying total surprise on the part of the U.S. at unfolding events over the canal. This text totally downplays the cooperation between the U.S. and Soviet Union in calling for a cease-fire: "The United States accordingly asked the United Nations to order both a cease-fire in Egypt, and the withdrawal of British, French, and Israeli troops. However, when the Soviet Union threatened to use missiles against Britain, and France, the United States warned that it would not tolerate such action" (p. 809). This text places responsibility for ending the fighting with the U.N and states: 
"Eventually the Suez Canal crisis simmered down" (p. 809). This textbook, like many others, lists the Eisenhower Doctrine as a consequence of the Suez crisis and increased "prestige" of the Soviet Union in the Middle East (p. 809).

(Holt 1995) In this text, Eisenhower's offer to finance Egypt's Aswan Dam is seen as a diplomatic rather than "covert" effort to "influence foreign policy" (p. 811). Like in other texts, Nasser's nationalization of the canal is seen as revenge for the withdrawal of U.S. financing. The major consequence of Nasser's nationalization, following with more recent editions of textbooks: "Nasser's nationalization of the canal posed many problems, including a threat to the Western oil trade" (p. 811). U.S. response to the invasions of Egypt is seen as a "difficult task". It is interesting to note that the text makes it seem that that the U.S. sided with the U.N. more than the Soviet Union, even quoting Eisenhower's reasoning to support a U.N resolution calling for an immediate cease-fire. Soviet threats to become involved with military force are not even mentioned. Consequences of the conflict included increased Soviet influence in the Middle East and the Eisenhower Doctrine in response.

(PH 1995) N/A

(HM 2003) Obvious relationships in this text are the antagonism Nasser tried to build upon between the U.S. and Soviet Union, Nasser's anger when the U.S. withdrew its financing offer, and French and British "[outrage]" at Nasser's nationalization of the canal (p. 831). The predominant cause for French and British involvement was their ownership of the "Egyptian waterway", and Israel's involvement stemmed from Egyptian blockage of ships bound for Israel. The text does state that the canal “... was supposed to be open to all nations" (p. 831). Major consequences of the Suez War, according to the 
text, were the increased prestige of the Soviet Union in the Middle East and the Eisenhower Doctrine in response.

(Holt 2003) The only relationships readily apparent in this text are Eisenhower's "support” of a UN cease-fire resolution, and after the Suez War, “...a friendlier relationship between the Soviet Union and Arab nations" (p. 849). The cause of the war seems to be Israel's initial attack into Egyptian territory. The UN resolution rather than Soviet threats are the cause of the cease-fire in this text and the two major consequences were increased prestige for the Soviet Union in the Middle East and the Eisenhower Doctrine in response.

(PH 2005) An obvious relationship in this text is the antagonism between the U.S. and Soviet Union because the U.S. "cut off their aid to Egypt" after learning Nasser was also seeking Soviet support (p. 891). The awkward diplomatic triangle resulting from the Suez War is found in this statement: "Reacting to Soviet threats of 'dangerous consequences,' a furious Eisenhower persuaded his NATO allies to withdraw from Egypt, which retained control of the canal" (p. 891). It is interesting to note that the UN is not even mentioned in this text and responsibility for a cease-fire is given to Eisenhower. Nasser's nationalization of the canal is seen as the cause of Britain and France's attack (Israel is not even mentioned!), and the consequence of the whole crisis, according to the text, is the Eisenhower Doctrine.

\section{On what premises is the account based and what assumptions are made in the course of the explanation (Larsen, 1991)?}

(PH 1957) This text's account is included in a section entitled, "Middle East Crisis", and is based on the premise that Nasser's nationalization of the canal, “....represented a 
powerful implicit danger to the economies of the western European countries, and flatly challenged American prestige throughout the world" (p. 754). The second part of this statement is interesting, since many historians view the Suez War as solidifying U.S. influence in the Middle East, as opposed to British and French influence prior to the war. Israel's motivation for going to war is based on the closed canal and in order to destroy bases being used for raids into Israel. The text states that although the fighting ended with the arrival of the United Nations Emergency Force, the Middle East remained a trouble spot.

(HM 1962) The assumption that Israel "suddenly" attacked Egypt in 1956 implies that it was not particularly planned, and may have been without cause (p. 781). It is also interesting to note that the text states Great Britain and France were "restrained by the United States" from using force to protect their interests in the canal. The assumption that Great Britain and France were later acting independently of Israel, when they sent bombers and a landing force to the canal is made in this text. Russia's threats of intervention, rather than the UN emergency force, are seen as the major factor in ceasing hostilities. The text states that although Nasser's army had been defeated, “...his position in the Arab world had been strengthened" (p. 781).

(Holt 1966) The major premise of this account is the increasing dissatisfaction with and distrust of western powers in the Middle East, along with American fears that the Soviet Union would gain a stronger foothold there by financially supporting projects like the Aswan dam and politically, by supporting small countries against western influences. It is assumed in this text that the U.S. withdrew its offer to pay for the Aswan dam because, "... it became clear that the U.S.S.R. could not at the time afford to finance the project..." 
(p. 780). No mention of Nasser's increasing anti-western sentiments is made in this text. Israel's motivation is seen in light of efforts to prevent a planned attack from Egypt. (PH 1967) The premise of this text's account is the United States' jockeying for diplomatic leverage in the Middle East, particularly with Egypt and its leader, Nasser. Later, the text states that Israel acted alone in their invasion of Egypt and also implies with the words "announced objectives" of the invasion, that there may have been other motives for Israel's attack, other than the officially announced objectives, although no collusion between Israel, Egypt, and France is implied (p. 840). After discussion of the Suez war, the text states: “...the Soviets continued to arm Arab nations...” (p. 840). (HM 1975) The major premise of the war's account in this text is that, "Egypt had been unfairly attacked, and the United States took a stand against the three invaders" (p. 697). It is assumed that Britain, France and Israel "reluctantly" withdrew their forces after pressure from the UN (p. 697). No motivation for Israel's role in the invasion is given. (Holt 1977) The major premise of this account is the increasing dissatisfaction with and distrust of western powers in the Middle East, along with American fears that the Soviet Union would gain a stronger foothold there by financially supporting projects like the Aswan dam and politically, by supporting small countries against western influences. It is assumed in this text that the U.S. withdrew its offer to pay for the Aswan dam because, "... it became clear that the U.S.S.R. could not at the time afford to finance the project..." (p. 689). No mention of Nasser's increasing anti-western sentiments is made in this text. Israel's motivation for involvement is given as forestalling a carefully planned attack on Israel, by Egypt. 
(PH 1976) The premise of this text's account is based on a Cold War context. A major assumption is that Israel invaded Egypt unilaterally, and based its invasion only on "rising tensions", as indicated by the statement: "American threats combined with those of the USSR brought the Israeli invasion to a halt a week later" (p. 655). The book also states that UN calls for a cease-fire went unheeded, and it was not until the Soviet Union stepped in with threats of unilateral action that a cease-fire was achieved. The book states that the UN peacekeeping force "solved nothing in the Middle East" (p. 655). The text also mentions that NATO alliances were strained by the events of the Suez War. (HM 1986) As seen in other texts, this account is based on a Cold War premise. It is assumed in this text that Israel, France, and Britain worked together in their attack on Egypt. Israel's only motivation for invasion is based on the closed canal in this text. (Holt 1986) The Cold War serves as this text's premise, with a secondary one possibly in Nasser's goals for the Middle East. Assumptions within the war's description include the Israeli governments reasoning that Egypt was orchestrating a planned attack on Israeli territory, as well as the assumption that Israel, France, and Britain were operating independently of one another.

(PH 1986) N/A

(HM 1996) This book is based on a Cold War premise, and Egypt is seen as a bargaining chip for influence in the Middle East between the United States (and Britain) and the Soviet Union. It is assumed that Israel, France, and Britain were cooperating in their attack on Egypt. Israel's motivation for invasion in this text are both the closed canal and terrorist raids into Israeli territory. 
(Holt 1995) Once again, the Suez War is seen in the light of the Cold War. One of the first assumptions in this text is that the U.S. cancelled its financing of the Aswan Dam simply because Nasser also turned to the Soviet Union for an offer. It is implied, but not explicitly stated that France and Britain may have been working in cooperation with Israel: "Great Britain and France, claiming they were protecting the canal, seized the Mediterranean end of the waterway a few days later [after Israel's attack]” (p. 812). Israel's motivation for attack in this text is the closed canal.

\section{(PH 1995) N/A}

(HM 2003) The premise of this text's account seems to be a search for peace in the Middle East. The paragraph on the Suez War follows directly after a summary of the Geneva Summit, in which the U.S. and Soviet Union attempted to work out an "open skies" policy between them. Although the Soviet Union rejected the idea, the book states: "...the world hailed the 'spirit of Geneva' as a step toward peace. In 1955, the same year in which the Geneva Summit took place, Great Britain and the United States agreed to help Egypt finance construction of a dam at Aswan on the Nile River" (p. 830831). It seems the text is trying to make the connection for the student that American financing was an effort to achieve peace in the Middle East, rather than a diplomatic attempt for influence in the Middle East. It is also assumed in this text that Nasser's playing the U.S. and Soviet Union against one another was simply an attempt to get more aid. It is difficult to conclude from this text, whether Great Britain, France, and Israel were working independently or together. In response to Nasser's nationalization, the text simply states: "Israel responded by sending troops. So did Great Britain and France. The three countries seized the Mediterranean end of the canal" (p. 831). The text states that 
the UN responded "quickly" and implies that the Suez War was solved without any real threat of war.

(Holt 2003) The premise for this text is within a Cold War context, but the paragraphs on the Suez War alone make little connection to the larger theater of the Cold War. The Suez War paragraphs do appear right next to a graph on "The Nuclear Threat, 19551960" that depicts U.S. and Soviet nuclear capabilities (p. 849). On the topic of Israel, France, and Britain, the implicit assumption seems to be that Israel attacked first and independently, then "a few days later", Britain and France attacked the Mediterranean end of the Suez Canal. This text however, does not mention Britain and France's attempts at a "cease-fire", which could imply that the three nations were working together, but unless a student knew that background information, the impression would be that Israel attacked separately from the other two nations. Israel's motivation for attacking in this text is the closed canal.

(PH 2005) The premise of this account involves U.S. efforts to keep Soviet influence out of the Middle East. There is very little text to pull out assumptions from, however, the text does imply that Britain and France coordinated their attack on Egypt.

\section{What perspectives, questions, theories are not acknowledged (Larsen, 1991)?}

(PH 1957) Nasser's motivations in turning to Russia for arms in 1955, and in nationalizing the canal are not addressed. French and British motivations for joining with Israel, aside from the canal, are not mentioned. U.S. response is seen only in the context of the United Nations, and does not indicate that the U.S. was surprised or even put into a difficult diplomatic position by the Anglo-French, Israeli alliance. Israel's motivation for going to war, other than Egyptian raids on Israeli territory are not mentioned, and neither 
is the 1955 Israeli raid into Gaza. The Baghdad Pact and the Lavon Affair (Egypt's execution of Israeli spies, plotting to blow up British and American areas in Cairo, in the hopes that Egypt would be blamed) are not mentioned either. Nasser's "anti-western" gestures (including his diplomatic recognition of communist China, and his decision to remain "non-aligned") are not explicitly mentioned.

(HM 1962) Questions left unanswered include why Nasser wanted to build the Aswan dam and why the U.S. was originally willing to help, why Nasser made an arms deal with the Soviets and why Nasser nationalized the canal. More specific motivations, other than the canal, for Great Britain, France, and Israel going to war with Egypt are also left out. U.S. response to the Anglo-French alliance, other than diplomatic pressure, is not included. Territorial gains and losses by Egypt and Israel are not mentioned.

(Holt 1966) Questions left unanswered include why the British decided to withdraw their troops from the canal zone in 1954, why the U.S. withdrew its offer to pay for the Aswan dam (aside from the text's assumption that the Soviet Union could not afford to pay for it). Important details left out include the arms build up in Egypt and Israel prior to 1956 , the fact that Nasser closed the canal only to Israeli ships, Nasser's relationship with other diplomats, particularly how western diplomats viewed him, is not mentioned.

(PH 1967) When the text states that the Gaza Strip was a "contested" area of Israel's border, it does not explain why, or that Egypt had occupied it since the 1948 war. It does later explain that Egypt had been launching raids into Israel, but does not specifically state weather they were from Gaza or from somewhere else within Egypt. Specific "antiwestern gestures" on Egypt's part are not listed. What Nasser's nationalization of the 
canal meant for other nations, specifically Israel's lack of continued access to the canal, is not addressed. Reasons for the "sudden" Anglo-French invasion of the Suez area are not given, although it is implied that the attack was in response to Israel's invasion of Egypt. Ulterior motives regarding use and control of the canal itself are not mentioned.

(HM 1975) This text is the most incomplete of those examined thus far. No context or specific information is given for growing "anti-Western feeling" in the Middle East. The complicated diplomacy regarding international financing of the Aswan Dam is not mentioned at all. Reasons for Egypt's nationalization of the Suez Canal and Israel's attack are not given, neither are France's or Britain's motivations for getting involved. (Holt 1977) Questions left unanswered include why the British decided to withdraw their troops from the canal zone in 1954, why the U.S. withdrew its offer to pay for the Aswan dam (aside from the text's assumption that the Soviet Union could not afford to pay for it). Important details left out include the arms build-up in Egypt and Israel prior to 1956 , the fact that Nasser closed the canal only to Israeli ships, Nasser's relationship with other diplomats, particularly how western diplomats viewed him, is not mentioned.

(PH 1976) It is interesting that this text does not mention, like the last edition, the "contested area” of the Gaza Strip. Bases, “...from which raids had been made on [Israeli] territory" are mentioned, but a specific location is not (p. 655). What Nasser's nationalization of the canal meant for other nations, specifically Israel's lack of continued access to the canal, is not addressed. Reasons for the "sudden" Anglo-French invasion of the Suez area are not given, although it is implied that the attack was in response to Israel's invasion of Egypt. Ulterior motives regarding use and control of the canal itself 
are not mentioned. Cooperation between Israel, Britain and France is not considered in this text.

(HM 1986) While concise, this text leaves out a lot of background information necessary to put the Suez War into any kind of historical or Cold War context. The Aswan Dam is not even mentioned and neither are Nasser's goals for Egypt and the entire Middle East. The arms build-up prior to the war is not mentioned. Egypt's decision to take over the canal is not put into any kind of context and seems to come out of the blue. Britain and Frances' motivations for joining with Israel are not clear in the text, and for that matter, neither is Israel's decision to attack Egypt made clear. (Although, a student could assume that Israel's involvement stemmed from their lack of access to the canal zone, even though no other reasons are mentioned in the text.)

(Holt 1986) Diplomatic negotiations and nuances of the Aswan Dam financing are completely overlooked, aside from a footnote stating: "In 1959 the Soviet Union agreed to provide money and engineers to build the [Aswan] Dam. Construction began in 1960 and was completed in 1969" (p. 839). Causes and consequences of this decision are overlooked. Nasser's anti-western sentiments are not mentioned at all in this book, Israel's involvement seems to be a side note to the real story between the U.S. and its NATO allies and Soviet threats to become involved with its own military force. Implications of Nasser's nationalization of the dam for other nations, other than the free flow of oil to western Europe, which is a significant addition from all previous editions and publishers.

(PH 1986) N/A 
(HM 1996) One unanswered question includes why Britain withdrew its troops from the Suez Canal Zone. Reasons for why Nasser delayed signing an agreement for the U.S. and Great Britain to finance the Aswan Dam are not given, other than implying Nasser hoped to get better terms from the Soviet Union. Reasons why the United States and Britain withdrew the financing offer for Aswan are not given, other than implying the wait (seven months) had been too long. Egypt's and Israel's arms build-up prior to the Suez War are not discussed, and any plans on the part of Egypt to attack Israel are not mentioned. Egyptian attacks on Israeli territory prior to 1956 are mentioned, but where those attacks were being made from and where they were taking place is not mentioned. Whatever happens with the canal (i.e. who ended up financing and building it) is not in the text.

(Holt 1995) While the U.S. offer to finance the Aswan dam is mentioned, and the reason given, according to the textbook, was meant to "influence foreign policy", the desired influence this financing was meant to have is not explicitly mentioned. Why Nasser also turned to the Soviet Union for financing is not addressed. (Arms deals on the part of Egypt and Israel prior to the Suez War are not mentioned.) International reaction to Nasser's nationalization of the canal is not addressed—only Israel's reaction to launch an attack. The only motivation for Israel to launch an attack, as seen in this textbook, is Egypt's blockage of "ships bound for Israel” (not Israeli ships as some other textbooks state) (p. 811). Attacks by Egypt into Israeli territory and counter-raids by Israel are not mentioned. Soviet threats to become involved with military force are not even mentioned, and unlike other texts which treated the Suez Crisis as the brink of another 
world war, this text makes the outcome seem ordered by the U.N. and almost predetermined.

(PH 1995) N/A

(HM 2003) Unanswered questions include why the U.S. and Great Britain agreed to finance construction of the Aswan Dam, specifically how Nasser "[played] the Americans and the Soviets against each other", and what sort of "deals" Nasser was making with the Soviets (p. 830). U.S. reaction to Britain, France, and Israel's invasion of Egypt is totally left out, as is all steps toward negotiating a cease-fire. The text simply states: "The UN quickly stepped in to stop the fighting. It persuaded Great Britain, France, and Israel to withdraw" (p. 830). Israel's only motivation for involvement, according to this text, is Egypt's refusal to allow ships bound for Israel to pass through the canal. Egypt's reasoning for blocking these ships is not given. It is interesting to note that historical context for the founding of Israel is in a special text box right next to the Suez War paragraphs, but the text box gives no indication that Israel's founding created any problems in the Middle East, in fact implying that the whole world was in favor of it. Neither do the Suez War paragraphs contain any context for understanding tensions between Israel, Egypt, and the rest of the Middle East.

(Holt 2003) Although very similar to the last edition, this text does not include details on the U.S.' original offer to finance Aswan, or reasons for its decision to withdraw financing. Reasons why Nasser decided to nationalize the canal are not even clear because of this text's efforts at brevity. The "many problems" resulting from Nasser's nationalization are not listed, except for the threat to Western oil trade (p. 849). Reasons for British and French involvement are not given — simply that they were involved is 
included. The only reason given for Israel's involvement is Egypt's blockage of the canal to ships bound for Israel. It is interesting to note that the text does not state this was contrary to international law. U.S. response to the attacks on Egypt or threats by the Soviet Union to become involved, are not included, other than Eisenhower's support for a UN cease-fire.

(PH 2005) The most glaring oversight in this text is the fact that Israel is nowhere mentioned in the Suez War! Diplomatic nuances involved in the financing of the Aswan Dam are not included, what Nasser was seeking aid for from the Soviet Union is not mentioned, UN involvement is not included, and in general, most historical context necessary for understanding the decisions that are mentioned were left out of this text.

\section{Six Day War:}

\section{1. "What are the underlying problems which have generated this discourse" (Larsen, 1991)?}

(HM 1975) The three sentences on the Six Day War appear in this text between a discussion on Kennedy's attempts at nuclear disarmament, and Johnson's involvement in the Vietnam War. There is no apparent underlying problem, only the statement that fighting "broke out", leaving Arab nations even more bitter than ever (p. 707).

(Holt 1977) This text's account of the war is in a chapter entitled, "Re-examining the Nation's Role in World Affairs 1960-1970's" (p. 693). The changing balance of power among Communist and Western leadership, and continued competition for influence, only this time in developing third-world countries, seems to be the predominant concerns in opening the chapter. The "Arab-Israeli conflict" subheading is between Kennedy's problems in Africa and his concerns over Cuba. The Middle East is seen as a continuing 
trouble spot in international tensions, and the underlying problem in this account is the Israeli belief that Arab nations were preparing to destroy their state.

(PH 1976) The underlying problem in this text can be found in the text statement, "The Egyptian leader [Nasser] immediately called for a 'Holy War' of Arabs against the Jewish state, Israel...for it was Soviet aid in arms and training that had encouraged Nasser's militancy" (p.694).

(HM 1986) There is really no apparent underlying problem in this text's account. The account is found under the heading, "International problems demand President Johnson's attention", but is not connected to the paragraphs before or after the three-sentence summary.

(Holt 1986) Much like the 1977 edition, the underlying problem in this account is the Israeli belief that Arab nations were preparing to destroy their state.

(PH 1986) The underlying problems in this text seem to be American and Soviet arms supplies to Israel and the Arab nations, respectively, along with Egyptian troop build up on the Sinai Peninsula (p. 706).

(HM 1996) The Six Day War is never explicitly mentioned in this text. In an introduction to the Camp David negotiations, the text does state: "As you know, between 1948 and 1973, four wars were fought between Arab nations and Israel” (p. 914).

(Holt 1995) The underlying problem in this text's account are post-1967 continued Arab and Israeli strikes and counterstrikes, and Soviet and U.S. arms supplied to Arab states and Israel following the Six Day War.

(PH 1995) Aside from being included on an international timeline at the start of chapter twenty-nine (“Civil Rights Movement” p. 795), the only other mention of 1967 is in an 
introduction to the Camp David Accords: "In that unstable region, conflicts between Israel and the Arab nations had existed, for nearly thirty years, most recently in 1967 and 1973” (p. 917).

(HM 2003) N/A

(Holt 2003) N/A

(PH 2005) N/A

\section{What theories provide the descriptions and explanations thought relevant?}

(HM 1975) There are no theories put forth in this text; the wording simply states: "There was further action too, in the Middle East, though this did not involve Americans.

Fighting broke out between Israel and her Arab neighbors in June of 1967. It lasted for only a few days, but it left the Arab nations more bitter and the situation in the Middle East more tense than before" (p. 707).

(Holt 1977) According to this text, from an Arab perspective, the Suez crisis had continued to breed bitterness, while Israelis in 1967, believed "Arab nations" were building up arms in an effort to destroy Israel (p. 694). "Occasional raids" by Israel and the "Arab nations" are also seen as a cause of the conflict.

(PH 1976) Soviet encouragement of Nasser's militancy is certainly the predominant theory that provides the explanations of the Six Day War. It is also interesting to note that Palestinian refugees are addressed in this account. Israel is seen as "evad[ing]" the issue, and Arab states "cynically exploited" them in their "overall determination to destroy Israel altogether" (p. 694).

(HM 1986) No underlying theory is found in this text. Fighting simply "broke out" between Israel and "Arab neighbors” (p. 691). 
(Holt 1986) The Israeli belief that Arab states were preparing to destroy Israel is the predominant theory leading to the 1967 conflict. A further source of bitterness stemmed from Israel keeping "large areas of land that had belonged to [Egypt, Jordan, and Syria]", after the conclusion of the conflict (p. 928). Unlike the last edition, raids by both sides prior to the conflict are not mentioned.

(PH 1986) The theory for Israel's surprise attack given in this text, is that Israel feared an attack from Egypt, based upon their troop movements in the Sinai Peninsula.

Although the dates or actual duration of the conflict (six days) is not given, an interesting side note is this text's explanation for why this conflict is called the Six Day War: “Because the Israelis advanced so quickly..." (p. 706).

(HM 1996) N/A

(Holt 1995) Egypt, Jordan, and Syria's crushing defeat in the Six Day War and the bitterness that resulted, is seen as the motivation for continued Arab raids into Israeli territory, and in return, counterstrikes by Israel.

(PH 1995) N/A

(HM 2003) N/A

(Holt 2003) N/A

(PH 2005) N/A

\section{What relationships, causes, consequences are proposed?}

(HM 1975) The only obvious relationship is hostility between Israel and "Arab neighbors" that was worsened by the 1967 conflict. There is no apparent cause in this text and the only consequence, according to the text, is increased Arab hostility and continued tension in the Middle East. 
(Holt 1977) Relationships in this text include the continued Arab hostility toward Israel, and after 1967, "more [determination] than ever to destroy Israel", Soviet aid and military supplies to Arab nations, U.S. aid for Arab nations aimed at poverty and U.S. military aid aimed at nations resisting Communism (p. 694-95). Causes of the war in this text are “occasional raids" by both sides, and Arab nations' massing of military forces. Consequences include Israel keeping "large areas of land that had belonged to [Egypt, Jordan, and Syria]", Arab bitterness at their swift defeat, Arab nations sending "trained guerrilla fighters into Israel" even after the war, Soviet military aid to Arab nations and not to Israel, and constant raids along Israel's border areas after the war (p. 694-95). (PH 1976) Relationships in this text include the UN function of "keeping Egypt and Israel apart for 10 years", Nasser's militancy toward Israel, an "Israeli-Arab conflict [which] defied solution", and Arab and Israeli avoidance of Palestinian refugees (p. 694). Nasser's militancy is seen as the cause of Israel's preemptive strike, and the consequence was Egypt's, and by extension Soviet, "humiliation" and an even bigger arms build up on both sides. Oil as an economic and political weapon caused the U.S. to "reassess its Middle East policies". Ultimately, enhanced Soviet prestige in the Middle East is seen as the consequence of American preoccupation with the Vietnam War (p. 694).

(HM 1986) The major consequence included in this three-sentence summary is that the 1967 conflict left the Middle East "more tense than before" (p. 691).

(Holt 1986) Relationships in this text include Israel's wariness of Arab intentions, Arab bitterness at their defeat and loss of land, U.S. aid for Arab nations aimed at poverty and U.S. military aid to Israel and also to nations resisting Communism (p.928). The major cause of the war in this text is Israel's belief that Arab nations wanted to destroy their 
state. Consequences include Israel keeping "large areas of land that had belonged to [Egypt, Jordan, and Syria]", Arab bitterness at their swift defeat, Arab nations sending "trained guerrillas" into Israel after the war, Soviet military aid to Arab nations and not to Israel, and retaliatory raids by Israel (p. 928).

(PH 1986) The only obvious relationship, although still not accompanied by any kind of descriptive adjectives or commentary to indicate what kind of relationship existed, the fact that Jordan and Syria joined Egypt in the fighting is mentioned. The cause of the war as stated in the text are the arms supplies coming to Israel and Arab states from the U.S. and Soviet Union, along with Egyptian troop build up in the Sinai. Text summary on the outcome of the war states: "It [Israel] drove the Egyptian forces from the Sinai Peninsula. It also captured territory from Jordan and Syria" (p. 706). No other commentary is provided.

(HM 1996) N/A

(Holt 1995) This text's account of the Six Day War is really given as historical background to the Yom Kippur War. Israel's crushing victory and Arab bitterness is the most obvious relationship in the account. Soviet allies among the Arab states and Israel as an ally of the U.S is also apparent. Since the account is an introduction to the Yom Kippur War, no initial cause for the Six Day War is given and there is no apparent conclusion or consequence, only that it was a "simmering" conflict in the Middle East, fueled by the Cold War (p. 904).

(PH 1995) N/A

(HM 2003) N/A

(Holt 2003) N/A 
(PH 2005) N/A

\section{On what premises is the account based and what assumptions are made in the course of the explanation (Larsen, 1991)?}

(HM 1975) This account is based on the premise that Johnson had to face many international conflicts, chief among them, Vietnam. This is confirmed by the section review question on the following page: "What international problems developed during the Johnson administration" (p. 708)? The two biggest assumptions are that fighting simply, "broke out", and that Americans were not involved.

(Holt 1977) The premise of this text's account is that the Middle East had long been and would continue to be a trouble spot for international conflict. The text's concluding statement on the 1967 war confirms this: "In 1970 the United States was able to secure a truce in the border raids, but a peaceful settlement of the Arab-Israeli conflict still seemed a distant prospect" (p. 695). One implication made in this text is that Israel's belief that Arab nations were massing military forces to destroy Israel may not have been correctit is never confirmed or denied in the text. It is only stated that Israel believed that to be the case, and so attacked with "powerful" force, in the process keeping land that had not previously belonged to them.

(PH 1976) The premise of this account is the diplomatic position of the U.S. in the Middle East, and its eventual reassessment of this position after considering oil's economic and political power, along with the 1967 conflict. The account itself is situated between a general discussion of President Johnson's international diplomacy and specific information on the Vietnam War. It is assumed in this text that UN troops were the only 
thing keeping Egypt and Israel apart, the overall Arab-Israeli conflict "defied solution", and that Arab states' exploitation of refugees was in an effort to destroy Israel (p. 694). (HM 1986) The premise of this account seems to be simply that the 1967 conflict was another challenge to Johnson's international diplomacy issues. From the lack of information, this text's implicit assumption is that the conflict was not important, in and of itself, and also because Americans were not directly involved.

(Holt 1986) This account is an interesting change from previous texts in that the premise is the American diplomatic policy of détente, and the challenge that the Middle East in general, represented for this policy. The text's account is found in a chapter entitled, "A New Role in World Affairs" (p. 914), and under the heading, "Détente with the Soviet Union" (p. 927). The 1967 conflict does not really seem to fit here since American and Soviet competition in aid and influence to the Middle East is still apparent after the conflict; it is not until the following paragraphs on the Yom Kippur War that détente is seen as having survived "its first critical test" (p. 929). One implication made in this text is that Israel's belief that Arab nations were massing military forces to destroy Israel may not have been correct-it is never confirmed or denied in the text. It is only stated that Israel believed that to be the case, and so attacked with "powerful" force, in the process keeping land that had not previously belonged to them (p. 929). Unlike the last edition, no assumptions or opening and concluding commentary are made about the possibilities of peace between Israel and its surrounding Arab states.

(PH 1986) This text's account is found in an entire section of chapter thirty-one ("Challenges to Peace"), entitled "Search for Peace in the Middle East" (p. 706). The text's introduction to this entire section mentions U.S. diplomatic balancing in the region, 
between "its ally Israel", and "Arab states that oppose Israel" (p. 706). This text avoids most of the assumptions of previous texts by making simple and concise factual statements, but in doing so, the text also misses many important points.

(HM 1996) It is interesting that this text assumes the student knows about the four wars fought between Israel and Arab states between 1948 and 1973, but that the Six Day War is never previously mentioned in the text itself.

(Holt 1995) This text's account of the Six Day War is found in the chapter "From Nixon to Carter 1970-1980, under the heading, "Relations with China and the Soviets" and the subheading, "Trouble spots" (p. 904). Like the last edition, détente is really the context which warrants the mention of the Middle East as a trouble spot to Nixon and Kissinger's policies. Much of the background to the Six Day War is eliminated in this edition. One quote by Golda Meir within the body of text includes the following assumption: "The only time that the Arab states were prepared to recognize the existence of...Israel was when they attacked it in order to wipe it out" (p. 904).

(PH 1995) N/A

(HM 2003) N/A

(Holt 2003) N/A

(PH 2005) N/A

5. What perspectives, questions, theories are not acknowledged (Larsen, 1991)? (HM 1975) Almost everything about the Six Day War is left unanswered in this text, except for the fact that it involved Israel; even the "Arab neighbors" are not listed specifically. The text's statement that it did not involve Americans leaves the student with the impression that the only way to be involved in international conflicts is with 
military force, and of course, any historian would acknowledge that American arms shipments were instrumental in Israel's 1967 victory.

(Holt 1977) Arms shipments to Israel and the Arab states are not mentioned prior to the war- only after the war are continued arms shipments to both sides mentioned. Arab perspective, other than bitterness at their defeat, and retaliatory border raids, is left out. No context for Egypt, Syria, and Jordan's involvement is given, through any discussion on politics and dissention within the Arab world, except for their unified hatred of Israel. The U.S.' decision to become Israel's primary arms supplier is not mentioned, nor are the motivations for the U.S. military aid that is mentioned in the textbook. Soviet arms supplies, according to the text, were meant to strengthen Soviet influence in the Middle East. International reaction to the conflict is left out, along with what really happened after the war was over, other than the continued border raids which the U.S managed to negotiate a stop to in 1970 (p. 695). Arab refugees are not mentioned in this text.

(PH 1976) Only Egypt is explicitly mentioned as an aggressor in this account, although other "Arab states" are mentioned, but not specifically. Reasons for Nasser's request of the UN to remove their troops are not given; the mention of Nasser's "Holy War" against Israel appears to have no motivation or context, other than a later mention of the goal to destroy Israel. American reaction to the conflict itself is not given, except regarding American consideration of oil in the region and general preoccupation with the Vietnam War at the time.

(HM 1986) The three-sentence summary of the conflict in this text leaves much to be desired. The only things answered about the conflict are that Americans were not directly involved in the fighting, it was between Israel and Arab neighbors, and it lasted for only a 
"short time" (691). The results of the conflict, or even who "won" are not there—only that it "left the situation in the Middle East more tense than before" (p. 691).

(Holt 1986) Arms shipments to Israel and the Arab states are not mentioned prior to the war- only after the war are continued arms shipments to both sides mentioned. Arab perspective, other than bitterness at their defeat, and retaliatory border raids, is left out. Egypt, Syria, and Jordan's reaction to Israel's initial invasion is not included, except for their bitterness at defeat. The U.S.' decision to become Israel's primary arms supplier is not mentioned, nor are the motivations for the U.S. military aid that is mentioned in the textbook. Motivations for Soviet arms supplies to the region are not mentioned, although a student could assume they were in response to similar American supplies. International reaction to the conflict is left out, and the 1967 conflict is really seen as a bridge to the main discussion on the Yom Kippur War (p. 928). Arab refugees are not mentioned in this text.

(PH 1986) Motivations for why the U.S. and Soviet Union continued supplying arms prior to the 1967 conflict is not included, and neither are the continued supplies to both sides, after the conflict. The impetus for Egypt's move to the Sinai Peninsula, and Jordan and Syria's motivations for joining them are not given. Specific territory that had been captured by Israel in the conflict is not included, only that territory from these three nations had been taken over by Israel. Who actually won the conflict is not explicitly stated, and any results or lingering consequences of the conflict are not included. International and U.S. reaction, along with the Arab states' reaction to Israel's preemptive strike are not given.

(HM 1996) N/A 
(Holt 1995) Much has been left out in this text's account. Most of the focus is on what happened after the conflict. The motivations of both sides in the conflict are not included, and no historical background or context for the conflict is given, although it is implied that Israel attacked first. No mention of the change in territorial borders after 1967 is made. International and U.S. reaction are not included.

(PH 1995) N/A

(HM 2003) N/A

(Holt 2003) N/A

(PH 2005) N/A

\section{Yom Kippur War:}

\section{1. "What are the underlying problems which have generated this discourse"}

(Larsen, 1991)?

(HM 1975) This text's account of the Yom Kippur or October War appears in a chapter entitled, "Americans Face the Challenge of a Modern World", under the subheading, "The Middle East flares up again". The very general subheading is also indicative of the general description given of the war. A major concern underlying this text's analysis was the possibility for direct conflict between the U.S. and the Soviet Union as a result of the 1973 war. A problem related to this possibility was the continuing shipments of military supplies from the Soviet Union and the U.S. to their Middle East allies, Egypt and Israel respectively.

(Holt 1977) The underlying problem in this text's account was whether or not détente would really end the threat of confrontation with the Soviet Union. Interestingly, (and 
extremely unique) is that this text ties the hope of détente's effectiveness to the easing of Soviet restriction on emigration, particularly emigration of Jews wanting to go to Israel. (PH 1976) The underlying problem in this text's account is American dependence on "the new reality of a unified bloc of oil exporting nations...[that] made suddenly urgent the long debated energy question" (p. 719).

(HM 1986) This text's account of the Yom Kippur or October War appears in a chapter entitled, "Americans Face the Challenge of a Modern World", under the subheading, "The Middle East flares up again". The very general subheading is also indicative of the general description given of the war. A major concern underlying this text's analysis was the possibility for direct conflict between the U.S. and the Soviet Union as a result of the 1973 war. A problem related to this possibility was the continuing shipments of military supplies from the Soviet Union and the U.S. to their Middle East allies, Egypt and Israel respectively.

(Holt 1986) The underlying problem in this text's account was whether or not détente would really end the threat of confrontation with the Soviet Union, and the dangers that the Middle East posed to détente policies.

(PH 1986) This textbook's whole discussion of the Middle East and Arab-Israeli wars appears in a subsection of chapter thirty-one (Challenges to Peace), entitled "Search for Peace in the Middle East" (p. 706). The underlying problems are many, but the predominant underlying problem for the 1973 conflict in this text is Egypt and Syria's attempt to regain lost territory from the 1967 Six-Day War.

(HM 1996) The underlying problem in this text can be found in the subheading to the section: "Crisis Follows Crisis in the Middle East" (p. 913). Because the text quickly 
summarizes the history of the region after World War II, the student would imply that the primary reason for conflict in the region is that "Arabs believed Israel had been created out of land that belonged to the Arabs" (p. 914).

(Holt 1995) The underlying problem in this text is (surprisingly for a 1990s text) Cold War competition between the Soviet Union and the United States, played out through their respective support of Egypt and Israel.

(PH 1995) There are two separate underlying problems in this text, because the 1973 conflict and the oil embargo are mentioned in separate sections of the textbook. Mention of 1973 is only to illustrate that previous attempts at peace, along with Kissinger's efforts at shuttle diplomacy, had been thus far unsuccessful. The underlying problem at the mention of the oil embargo is America's already "troubled" economy (p. 888).

(HM 2003) The underlying problem in this text is "years of intense border disputes" between Israel and Egypt and Syria (p. 1005).

(Holt 2003) The Yom Kippur War is not mentioned in this text, except on a map where the locations of the fighting (Egypt and Syria) are labeled. The map is titled, "Conflicts in the Middle East, 1948-1981” (p. 1030). The Arab oil embargo is mentioned at length, and the underlying problem is primarily American demand for oil increasing above its production capabilities. The secondary problem is American support for Israel "in a new Arab-Israeli war" (p. 1015).

(PH 2005) The underlying problem in this text is simply "unrest in the Middle East [which] turned the energy problem into a crisis" (p. 1060).

\section{What theories provide the descriptions and explanations thought relevant?}


(HM 1975) The predominant theory in this account can be found in the following quote:

"The Soviet Union and the United States have always been vitally interested in the Middle East” (p. 720). Specifics of that statement are not expounded on except regarding shipments of military arms to the region. The account is concisely but insufficiently summed up with: "But, as in the past, a cease-fire, supervised by the United Nations, was worked out" (p. 720). The theory is presented that peace was possible between Israelis and Arabs because of the 1974 talks in Geneva, Switzerland between "Arab countries, the Soviet Union, Israel, the United States, and the United Nations”, whereas before, “...it had been impossible to get the Arabs and Israelis even to talk to one another..." (p. 720). (Holt 1977) The predominant theory in this text was that the Yom Kippur War was the first "major test of détente and of Secretary Kissinger's skill as a diplomat" (p. 707). It is recognized that only the influence of "the two great powers persuaded the Arabs and the Israelis to accept the cease-fire and to prepare of negotiations" (p. 707). This text is much less hopeful about the long-term prospects of the "precarious" peace that was established in the region.

(PH 1976) The theory here is that the Arab oil embargo was the result of the Arab-Israeli war.

(HM 1986) The underlying theory can be found in the following quote: "During this October War, the Soviet Union gave help to the Arabs, while Israel received supplies from the United States" (p.695-696). This text's account is still seen, for the most part, in a Cold War context, however, a map on page 696 does point out the strategic importance of the Suez Canal. The account is concisely but insufficiently summed up with: "But, as 
in the past, a cease-fire was worked out" (p. 698). No other mention of the conclusion of the war or the proceeding negotiations is made.

(Holt 1986) The predominant theory in this text was that the Yom Kippur War was the first "critical trial" of détente (p. 929). It is recognized that only the influence of "the two great powers persuaded the Arabs and the Israelis to accept the cease-fire and to prepare of negotiations" (p. 929). This text is much less hopeful about the long-term prospects of the "uneasy" peace that was established in the region.

(PH 1986) Prominent theories that prompt discussion of the 1973 war in this text includes Soviet and American arms supplies to Egypt and Israel and international pressure on Israel to give back “occupied lands" gained from Israel's victory in 1967 (p. 707).

(HM 1996) The predominant theory for continuing conflict in the region is found in the short statement: "Between 1948 and 1973, four wars were fought between Arab nations and Israel. Much of the Arab manpower and weaponry came from Egypt" (p. 914). (Holt 1995) The predominant theory in this text is that "embittered" Arab states continued to "harass" Israel after the Six-Day War, and this "simmering conflict was fueled by Cold War competition" (p. 904). A quote included by Golda Meir reinforces the idea that the Arab states' sole objective was destroy Israel.

(PH 1995) The theory for the 1973 conflict is found in the following statement: "In that unstable region, [Middle East] conflicts had existed for nearly thirty years, most recently in 1967 and 1973" (p. 917) So the only theory for the conflict is simply that it was an "unstable region". Theory regarding the oil embargo is that Americans were so crippled 
by it because they "depended on cheap, imported oil for about a third of their energy needs" (p. 888).

(HM 2003) Theory apparent in this account is that even though the U.S. was supplying Israel with "massive amounts of military aid", U.S. efforts were primarily directed at obtaining a peace agreement between Israel and her enemies.

(Holt 2003) The only apparent theory is that America's energy crisis was due in part to its support of Israel, but primarily because demand for oil exceeded production, and relied heavily on foreign imports.

(PH 2005) This text's theory is very similar to Holt's (2003), in that America's energy crisis was due in part to its support of Israel, but primarily because demand for oil exceeded production, and relied heavily on foreign imports.

\section{What relationships, causes, consequences are proposed?}

(HM 1975) Relationships include the "uneasy peace" in the region, a clear alliance between Egypt and Syria in their attack on Israel, Soviet aid to Arab states, American aid to Israel, and Henry Kissinger's central role in the cease-fire and peace talks, and Arab use of oil as political leverage. The cause of the October War, as this text calls it, is unknown from the account that is given. The "uneasy peace" between Israel and Arab neighbors simply "broke down again" (p. 720). One cause could be implied from a later mention of Soviet and American military supplies in the region, but it is never explicitly stated as the cause. Causes of Israel's successful counterattack, after their initial surprise, are not given, although the arms shipments could again be implied. The United Nations is seen as the reason both sides agreed to a cease-fire. The only consequence mentioned was the possibility "to hope that peace might at last come to the Middle East" (p. 720). 
(Holt 1977) Relationships include the alliance between Egypt and Syria, the ineffectiveness of the UN at negotiating a cease-fire, American diplomatic influence over Israel, heightened tensions between the U.S. and Soviet Union as a result of the war, Israeli "bitterness at being forced to end the fighting just as a decisive victory was within grasp", Arab anger at American support for Israel, and a "precarious peace" in the region (p. 708). One cause of the war is explicitly stated in this text: "Egypt and Syria, seeking to recover territories lost in the 1967 war suddenly launched an attack upon Israel” (p. 707). The cause of an eventual cease-fire agreement ultimately begins in this text, with Israel's success at a counter-attack, which forced Egypt to call upon the Soviet Union for help, whose threats to send troops of their own caused American diplomacy to favor a cease-fire and work at persuading Israel into agreement. Consequences of the conflict included Israeli "bitterness at being forced to end the fighting just as a decisive victory was within grasp", Arab anger at American support for Israel, and the oil embargo (although this is mentioned at the end of the text account, and seems to be a consequence of the war, rather than being enacting during the war). The text does state that the embargo was aimed at nations "friendly to Israel" (p. 709). The ultimate consequence in this text is that détente had survived its first real international test.

(PH 1976) Relationships evident in this very short mention of October 1973 are America's preoccupation with Watergate, as well as its dependence on Middle Eastern oil. There is no mention of a cause for the outbreak of war in 1973, and its only consequence seems to be the oil embargo, that "raised havoc with available domestic supplies [and] sent gasoline prices skyrocketing...” (p. 718). 
(HM 1986) Relationships include the "uneasy peace" in the region, a clear alliance between Egypt and Syria in their attack on Israel, Soviet aid to Arab states, American aid to Israel, and Arab use of oil as political leverage. The cause of the October War, as this text calls it, is unknown from the account that is given. The "uneasy peace" between Israel and Arab neighbors simply "broke down" (p. 695). One cause could be implied from a later mention of Soviet and American military supplies in the region, but it is never explicitly stated as the cause. Causes of Israel's successful counterattack, after their initial surprise, are not given, although the arms shipments could again be implied. Unlike the last edition, the United Nations and Henry Kissinger's efforts are not even mentioned. Consequences, aside from the oil embargo and fuel shortages, are not mentioned.

(Holt 1986) ) Relationships include the alliance between Egypt and Syria, the ineffectiveness of the UN at negotiating a cease-fire, American diplomatic influence over Israel, heightened tensions between the U.S. and Soviet Union as a result of the war, Israeli "bitter[ness] at being forced to end the fighting just as a final victory was within grasp", Arab anger at American support for Israel, and an "uneasy peace" in the region (p. 928-929). One cause of the war is explicitly stated in this text: "Egypt and Syria, seeking to recover territories lost in the 1967 war suddenly launched an attack upon Israel" (p. 707). The cause of an eventual cease-fire agreement ultimately begins in this text, with Israel's success at a counter-attack, which forced Egypt to call upon the Soviet Union for help, whose threats to send troops of their own caused American diplomacy to favor a cease-fire and work at persuading Israel into agreement. Consequences of the conflict included Israeli "bitter[ness] at being forced to end the fighting just as a final 
victory was within grasp", Arab anger at American support for Israel, and the oil embargo (although this is mentioned at the end of the text account, and seems to be a consequence of the war, rather than being enacting during the war). The text does state that the embargo was aimed at nations "friendly to Israel" (p. 929). The ultimate consequence in this text is that détente had survived its first real international test. Interestingly, (and like the last edition) is that this text ties the hope of détente's effectiveness to the easing of Soviet restriction on emigration, particularly emigration of Jews wanting to go to Israel. Continued Soviet restrictions on Jewish emigration is seen in this text as a "setback for the policy of détente" (p. 929).

(PH 1986) Relationships include Egypt and Syria's alliance, Soviet support for Egypt and U.S. support for Israel, OPEC's (Organization of Petroleum Exporting Countries) use of oil as an economic weapon, and continued Arab refusal to officially recognize Israel. Causes of the 1973 War in this text stem from Egypt and Syria's grievances left over from the 1967 Six-Day War. The continuation of the conflict was made possible by Soviet and American arms shipments to the region. The immediate consequence of the conflict was the Arab oil embargo, meant to "protest American support for Israel...[and] put pressure on the United States and other nations to make Israel give back the 'occupied lands' Israel had taken from Egypt, Jordan, and Syria” (p.706-707). Interesting to note is that this is the first text to actually use the term "occupied lands" to describe territory gained by Israel in 1967. This is also the first text to mention Kissinger's "shuttle diplomacy" by that name, and according to this text, it was his efforts that arranged the 1973 cease-fire. This text also states that Kissinger was unable to resolve continued Arab refusal to recognize Israel's legitimacy. Overall, this text had a lot of 
"firsts": mention of "occupied lands" and OPEC's role in bargaining for the return of those lands, continued Arab refusal to recognize Israel, and Palestinian refugees as a "major stumbling block to peace" that any peace settlement would have to solve (p. 709). (HM 1996) Relationships include continuing hostility between Arab states and Israel and Kissinger's shuttle diplomacy. No cause for the 1973 war is given, other than the root cause for all of the wars according to the textbook, that Arabs believed Israel was created out of Arab lands. No other mention of 1973 is made, but Kissinger's shuttle diplomacy resulted in a "temporary agreement" in 1975. "Israel promised to partially withdraw its troops from Egypt's Sinai Peninsula. In exchange, the United States promised to supply Israel with advanced arms and aircraft" (p. 914). Another consequence was the Arab oil embargo and Americans' surprise "that the United States was dependent on foreign nations for more than a third of its oil" (p. 905).

(Holt 1995) Relationships include the alliance between Egypt and Syria, American diplomatic influence over Israel, heightened tensions between the U.S. and Soviet Union as a result of the war, and Soviet and American arms supplies to Egypt and Israel. One cause of the war is explicitly stated in this text: "Then, in October 1973, Egypt and Syria invaded Israel, seeking to recover land lost in the 1967 war" (p. 904). The cause of an eventual cease-fire agreement ultimately begins in this text, with Israel's success at a counter-attack, which forced Egypt to call upon the Soviet Union for help, whose threats to send troops of their own caused American diplomacy to favor a cease-fire and work at persuading Israel into agreement. Consequences of the conflict are not really mentioned, aside from a doubtful prospect for peace in the region. The ultimate consequence in this text is that détente had survived its first real international test. Interestingly, this text 
does not mention the oil embargo in the paragraphs discussing the Six-Day War and Yom Kippur War, but there is mention earlier in the textbook under the subheading, "Energy Crisis" (p. 902). The text does explain that the embargo was a consequence of American support for Israel during the 1973 war. Unlike the last two editions, this text does not mention continued Soviet restrictions on Jewish emigration, particularly to Israel.

(PH 1995) Relationships in this text include American dependence on foreign oil, Egypt and Syria's alliance, American friendship with Israel, OPEC retaliation for American support of Israel during the 1973 war, and Kissinger's efforts on behalf of both Israel and Arab nations to obtain peace. No apparent cause for the 1973 conflict is given in the text. It is only stated: "In 1973, Israel and the Arab nations of Egypt and Syria went to war" (p.888). The cause of the oil embargo is America's support for Israel during the war. Consequences of the oil embargo that the text addresses are higher inflation, and economic recession, and higher unemployment. The only consequence of the 1973 war apparent in the text, is Kissinger's failed attempt at shuttle diplomacy (p. 917). (HM 2003) Relationships in this text include Syria and Egypt's alliance in invading Israel, U.S. support of Israel, OPEC's protests of U.S. military aid to Israel, and Kissinger's shuttle diplomacy. The cause of the 1973 war in this text was "the climax of years of intense border disputes" (p. 1005). The cause of the oil embargo was American support for Israel. Consequences of the war were its "brutal" nature (the textbook lists casualty numbers for Egypt, Syria, and Israel) and Kissinger's successful efforts at shuttle diplomacy, which resulted in peace agreements for all three nations. Consequences of the oil embargo were the permanent rise in prices for oil and economic inflation for the U.S. economy (p. 1005). 
(Holt 2003) Continuing American support for Israel and OPEC's displeasure over this continued support are the two most apparent relationships in this text. No other discussion of the Yom Kippur War is included. The only consequence given is that even after the embargo was lifted, the price of oil remained high.

(PH 2005) Relationships in this text (including a special text box on Kissinger's shuttle diplomacy on page 1069) include American dependence on foreign oil, OPEC's retaliation for American support of Israel, Israel and Egypt/Syria's warring status, and Kissinger's efforts at shuttle diplomacy. Causes of the 1973 war are not included in this text. The cause of the oil embargo is American support for Israel. Consequences of the oil embargo were inflation and recession. Consequences of the war include Kissinger's success at negotiating a cease-fire agreement between Israel and Syria, and current diplomats' efforts to copy Kissinger's shuttle diplomacy in order to "further U.S. foreign policy goals" (p. 1069).

\section{On what premises is the account based and what assumptions are made in the course of the explanation (Larsen, 1991)?}

(HM 1975) The premise of this account is that the October War was just another conflict, in a long line of historical tensions in the region, and although there may have been hope for peace because of the 1974 talks, it was not a guarantee. It is assumed that because Arabs and Israelis were talking, that the possibility for peace was real this time. It is interesting to note that this text does not blame the October War for the nation's energy crisis, but only mentions that the oil shortage was made worse by the conflict. The text does state the Arab nations' motivation for cutting production: “...Arab nations cut off supplies of oil to the United States and other nation, hoping thus to persuade these 
countries not to support Israel” (p. 720). In the very next sentence however, the text states that Arab nations lifted the embargo because, “...they were grateful for America's help in bringing an end to the fighting...” (p. 720).

(Holt 1977) The premise of this account is that the war was the first real (and successful) test of détente and Kissinger's skills as a diplomat. A major implicit assumption is that the U.S. and Soviet Union were only involved in negotiating the cease-fire and peace talks, because no mention of arms shipments prior to the war are made. Also because of this is the assumption that it was Israel's "powerful" force that drove Egypt back across the Suez Canal to "certain defeat" and Syrian troops further north (p. 707).

(PH 1976) The premise of this account is really America's preoccupation with Watergate. The implicit assumption is that the 1973 Arab-Israeli conflict was only important because it affected domestic oil supplies.

(HM 1986) The premise of this account is that the October War was just another conflict, in a long line of historical tensions in the region. One assumption implicit in the text is that this war was unique since Israel was not the aggressor: "This time Egypt and Syria launched a surprise attack..." (italics added p. 695). Unlike the last text, the possibilities for peace, or even the negotiations following the cease-fire, are not mentioned. Although the 1975 edition did not blame the October War for the nation's energy crisis, but only mentions that the oil shortage was made worse by the conflict, the 1986 edition does make a direct correlation between the conflict and the oil embargo. The text does state the Arab nations' motivation for cutting production: "At the time of the October War, some Arab nations cut off oil shipments to the United States. They did this to try to stop our country from helping Israel” (p. 696). The text only states that the 
Arab oil embargo "soon" ended, but does not explain why. Consequences of the war are not really addressed, except the statement: "[The oil embargo] made Americans see the danger of depending on other nations for such an important source of energy as oil" ( $p$. 696).

(Holt 1986) The premise of this account is that the war was the first real (and successful) test of détente. A major implicit assumption is that the U.S. and Soviet Union were only involved in negotiating the cease-fire and peace talks, because no mention of arms shipments prior to the war are made. Also because of this is the assumption that it was Israel's "powerful" force that drove Egypt back across the Suez Canal to "certain defeat" and Syrian troops further north (p. 707).

(PH 1986) The premise of this text's account is found in the following statement: "For years, the United States has worked for peace in the Middle East" (p. 707). It is assumed that the 1973 conflict really did nothing to change territorial borders or the status-quo in the Middle East, and that Kissinger's efforts alone arranged the 1973 cease-fire. The text's concluding commentary on the Arab-Israeli conflict also includes its prominent assumptions: "The major stumbling blocks to peace in the Middle East have been the Palestinian refugees and the occupied lands...Any peace settlement will have to solve this difficult problem" (p. 708).

(HM 1996) The premise of this account can be found in the opening statements to the section: "The Middle East is one of the world's trouble spots. It is an area of many ethnic, religious, and economic conflicts" (p. 913). The major assumption the text makes is that students already know about all four Arab-Israeli conflicts between 1948 and 1973. 
(Holt 1995) The premise of this account is that the war was the first real (and successful) test of détente. The primary assumption is found in the following statement: "Détente had survived its first critical test, but prospects for a lasting peace in the Middle East remained in doubt" (p. 904).

(PH 1995) The major premise of this text's account is that no solution had yet been found to establish a long lasting peace in the Middle East. The text's primary assumption is that students have prior knowledge of the Yom Kippur War.

(HM 2003) This account is based on the premise that although the Yom Kippur War was short, it was unusually brutal. An assumption implicit in the text is that both sides may have been justified in going to war, and also that Kissinger's peace agreements were a long lasting solution for peace in the region.

(Holt 2003) This account is based on the premise that American dependence on foreign oil creates a vulnerable and fragile economy. The implicit assumption in this text's summary is that Arab-Israeli conflicts are relevant only because they affect American access to Middle Eastern oil.

(PH 2005) The premise of this text is similar to Holt (2003) in that American dependence on foreign oil creates a vulnerable and fragile economy. The implicit assumption in this text's summary is that Arab-Israeli conflicts are relevant only because they affect American access to Middle Eastern oil. The text also assumes that Kissinger was successful in establishing a long-standing peace in the Middle East and that his efforts should be copied.

\section{What perspectives, questions, theories are not acknowledged (Larsen, 1991)?}


(HM 1975) Significant oversights in this text include: historical context prior to the war or even initial causes of the breakdown in peace between Egypt, Syria, and Israel; motivations for why Syria and Egypt formed an alliance are not given; no mention of Yom Kippur or the significance for the date of the surprise attack on Israel; actual locations of the fighting (Suez Canal, Sinai, Golan Heights) are not mentioned; the death of Nasser and succession of Sadat in Egypt; the breakdown of relations between Egypt and the Soviet Union prior to the war; no mention of the PLO's increased importance in Middle East diplomacy (Palestine Liberation Organization) or even changing international opinion toward Palestinians (favorable) and Israel (negative); Israel's technical military victory and the Arab states' psychological victory are not addressed; Kissinger's shuttle diplomacy is not mentioned; international reaction to the oil embargo; and finally, growing international awareness of the Arab-Israeli conflict along with America's increased influence in the region are not included in this account.

(Holt 1977) Significant oversights in this text include: historical context prior to the war or even initial causes of the breakdown in peace between Egypt, Syria, and Israel; actual locations of the fighting (Suez Canal, Sinai, Golan Heights) are not mentioned; the death of Nasser and succession of Sadat in Egypt; the breakdown of relations between Egypt and the Soviet Union prior to the war; no mention of the PLO's increased importance in Middle East diplomacy (Palestine Liberation Organization) or even changing international opinion toward Palestinians (favorable) and Israel (negative); Israel's technical military victory and the Arab states' psychological victory are not addressed; Kissinger's shuttle diplomacy is not mentioned; international reaction to the oil embargo; 
and finally, growing international awareness of the Arab-Israeli conflict along with America's increased influence in the region are not included in this account.

(PH 1976) Since this text's account is so short, everything remains unacknowledged with the following exceptions: an Arab-Israeli war "broke out" in October 1973 and it resulted in an Arab oil embargo that raised domestic oil prices and increased American awareness of the "energy question" (p. 718).

(HM 1986) Significant oversights in this text include: historical context prior to the war or even initial causes of the breakdown in peace between Egypt, Syria, and Israel; motivations for why Syria and Egypt formed an alliance are not given; no mention of Yom Kippur or the significance for the date of the surprise attack on Israel; the death of Nasser and succession of Sadat in Egypt; the breakdown of relations between Egypt and the Soviet Union prior to the war; no mention of the PLO's increased importance in Middle East diplomacy (Palestine Liberation Organization) or even changing international opinion toward Palestinians (favorable) and Israel (negative); Israel's technical military victory and the Arab states' psychological victory are not addressed; Kissinger's shuttle diplomacy is not mentioned; international reaction to the oil embargo; and finally, growing international awareness of the Arab-Israeli conflict along with America's increased influence in the region are not included in this account. Unlike the last edition, some actual locations of the fighting (Suez Canal and Damascus) are mentioned.

(Holt 1986) Significant oversights in this text include: historical context prior to the war or even initial causes of the breakdown in peace between Egypt, Syria, and Israel, other than territory lost in 1967; the death of Nasser and succession of Sadat in Egypt; the 
breakdown of relations between Egypt and the Soviet Union prior to the war; no mention of the PLO's increased importance in Middle East diplomacy (Palestine Liberation Organization) or even changing international opinion toward Palestinians (favorable) and Israel (negative); why OPEC lifted the oil embargo; Israel's technical military victory and the Arab states' psychological victory are not addressed; Kissinger's shuttle diplomacy is not mentioned; cease-fire and peace negotiations are not included; international reaction to the oil embargo; and finally, growing international awareness of the Arab-Israeli conflict along with America's increased influence in the region are not included in this account.

(PH 1986) Significant oversights in this text include: motivations for why Syria and Egypt formed an alliance are not given; actual locations of the fighting (Suez Canal, Sinai, Golan Heights) are not mentioned; the death of Nasser and succession of Sadat in Egypt; the breakdown of relations between Egypt and the Soviet Union prior to the war; no mention of the PLO's increased importance in Middle East diplomacy (Palestine Liberation Organization) or even changing international opinion toward Palestinians (favorable) and Israel (negative); why OPEC lifted the oil embargo, even though Israel still retained "occupied" lands; Israel's technical military victory and the Arab states' psychological victory are not addressed; international reaction to the oil embargo; and finally, growing international awareness of the Arab-Israeli conflict along with America's increased influence in the region are not included in this account.

(HM 1996) Since this text's account is so short, everything remains unacknowledged with the following exceptions: there were four Arab-Israeli wars between 1948 and 1973, "much of the Arab manpower and weaponry came from Egypt", the Arab oil embargo 
was the result of the "United States and other western nations giving aid to Israel" (p. 905), and Henry Kissinger carried on "shuttle diplomacy...trying to get the two nations to resolve their differences" (p. 914).

(Holt 1995) Significant oversights in this text include: initial causes of the breakdown in peace between Egypt, Syria, and Israel, other than territory lost in 1967; the death of Nasser and succession of Sadat in Egypt; the breakdown of relations between Egypt and the Soviet Union prior to the war; no mention of the PLO's increased importance in Middle East diplomacy (Palestine Liberation Organization) or even changing international opinion toward Palestinians (favorable) and Israel (negative); why OPEC lifted the oil embargo; Israel's technical military victory and the Arab states' psychological victory are not addressed; Kissinger's shuttle diplomacy is not mentioned; cease-fire and peace negotiations are not included; international reaction to the oil embargo; and finally, growing international awareness of the Arab-Israeli conflict along with America's increased influence in the region are not included in this account. (PH 1995) Since this text's account is so short, everything remains unacknowledged with the following exceptions: There was a war between Egypt/Syria and Israel in 1973, OPEC used oil as an economic weapon to protest American support of Israel during this war, and Kissinger's attempts at shuttle diplomacy were unsuccessful in the long-term peace of the region.

(HM 2003) Significant oversights in this text include: historical context prior to the war or even initial causes of the breakdown in peace between Egypt, Syria, and Israel; motivations for why Syria and Egypt formed an alliance are not given; actual locations of the fighting (Suez Canal, Sinai, Golan Heights) are not mentioned; the death of Nasser 
and succession of Sadat in Egypt; Soviet military supplies to Egypt are not mentioned, even though U.S. supplies to Israel are mentioned; the breakdown of relations between Egypt and the Soviet Union prior to the war; no mention of the PLO's increased importance in Middle East diplomacy (Palestine Liberation Organization) or even changing international opinion toward Palestinians (favorable) and Israel (negative); Israel's technical military victory and the Arab states' psychological victory are not addressed; international reaction to the oil embargo; why OPEC lifted the embargo; and finally, growing international awareness of the Arab-Israeli conflict along with America's increased influence in the region are not included in this account.

(Holt 2003) Since this text's account is so short, everything remains unacknowledged with the following exceptions: a "new Arab-Israeli war" broke out in October 1973, OPEC raised oil prices in protest of American support for Israel during this war, the embargo triggered an energy crisis and inflation, and once the embargo was lifted, the price of oil remained high (p. 1015).

(PH 2005) This text has the particular distinction of not even mentioning who initiated the Yom Kippur War. It states: "In 1973, Israel and the Arab nations of Egypt and Syria went to war" p. 1060) Since this text's account is so short, everything remains unacknowledged with the following exceptions: Israel, Egypt, and Syria's warring status in 1973, OPEC's oil embargo, American support for Israel during the 1973 conflict, the fact that Israeli and Syrian forces were fighting on the Golan Heights, and Kissinger's shuttle diplomacy and success at negotiating a cease-fire. 


\section{Camp David Accords:}

\section{1. "What are the underlying problems which have generated this discourse" (Larsen, 1991)?}

(HM 1986) The two sentences regarding the peace agreement appear under the heading,

“The President supports human rights", along with mention of Carter's goals in Panama, and foreign policy of "cutting off aid to countries that did not respect human rights" ( $p$. 706).

(Holt 1986) The underlying problem in this text is a "troubled Middle East" where the renewal of war was always a possibility (p. 931).

(PH 1986) The underlying problem in this text seems to be the breakdown of peace talks prior to Camp David, although no detail of these prior negotiations is given.

(HM 1996) The underlying problem in this text can be found in the opening paragraph which states: "The Middle East is one of the world's trouble spots. It is an area of many ethnic, religious, and economic conflicts" (p. 913). The underlying problem between Egypt and Israel specifically in this text is because in the wars fought between them, "Much of the Arab manpower and weaponry came from Egypt" (p. 914).

(Holt 1995) Underlying problems in this text are two-fold, and include, "deadlocked" talks prior to Camp David, as well as Arab criticism of Sadat "for attempting any peace talks with Israel” (p. 915)

(PH 1995) Two underlying problems are apparent in this text: first is Carter's desire to find "ethical solutions to prickly problems...in the Middle East question" (p. 917); 
second, the book introduces Camp David with the statement: "In that unstable region, conflicts between Israel and the Arab nations had existed for nearly thirty years" (p. 917). (HM 2003) The underlying problems in this text are the "long gasoline lines and high energy costs" Americans were facing as a result of "ethnic, religious, and economic conflict in the Middle East and the long-time antagonism between Israel and Egypt (p. 1022).

(Holt 2003) The underlying problem in this text is that Carter took office "amid fears of more Egyptian-Israeli armed conflict" (p. 1031).

(PH 2005) Two underlying problems are apparent in this text: first is Carter's desire to finding "ethical solutions to complicated problems...in the Middle East" (p. 1087); second, the book introduces Camp David with the statement: "In that unstable region, Israel and the Arab nations had fought several wars (p. 1087).

\section{What theories provide the descriptions and explanations thought relevant?}

(HM 1986) The only theory present in the two sentence mention of the Egypt-Israel agreement is that Carter worked hard at the agreement in order to "reduce tension in the Middle East” (p. 706).

(Holt 1986) The impetus leading to negotiations in this text is Begin's invitation to Sadat to visit Israel. The proceeding visits to Egypt and Israel on behalf of both leaders, along with U.S. Secretary of State Vance's efforts, "ended in a stalemate" after nine months of negotiations (p. 931). Discussion of Camp David follows this contextual information.

(PH 1986) The impetus in this text for beginning negotiations was Sadat's agreement o visit Israel, "as the first Arab head of state to visit Israel" (p. 708). Carter's efforts to 
keep peace talks from breaking down even further seem to be his motivation for the invitation to Camp David.

(HM 1996) The predominant theory in this text is Egypt and Israel fought four wars because of disagreement over the land, and official Arab recognition of Israel. The text also mentions that Israel was willing to withdraw from the Sinai because of U.S. promises "to supply Israel with advanced arms and aircraft" (p. 914).

(Holt 1995) There is a large amount of text on Sadat himself, and the focus seems to be largely on Sadat's efforts in "trying to pave the road to peace" (p. 916) An implied theory could be that without Sadat, no peace would have been possible. There is no hint that the negotiations were in the least bit arduous, instead the text mentions "an emotionfilled ceremony [where] each quoted the prophet Isaiah", and highlights the Nobel Peace Prize each leader received for their efforts.

(PH 1995) The first theory apparent in this text is that Kissinger's shuttle diplomacy was ultimately unsuccessful since conflicts had continued in the region. The second is that negotiations before Camp David between Sadat and Begin were unsuccessful because "the two men had such different personalities" (p. 918). Carter's hopes to "smooth their differences and move the peace process forward", is what ultimately prompted Carter to invite the leaders to Camp David (p. 918).

(HM 2003) The underlying theory in this text's account is that is was Carter's "negotiation and arm-twisting" that produced results at Camp David and that is was "one of his greatest diplomatic triumphs" (p. 1022).

(Holt 2003) The theory underlying this text's account is that Camp David was Carter's chief foreign policy triumph. 
(PH 2005) The first theory apparent in this text is that negotiations before Camp David between Sadat and Begin were unsuccessful because "the two men had such different personalities" (p. 1087).

\section{What relationships, causes, consequences are proposed?}

(HM 1986) The only apparent relationship is Carter's role as mediator between Egypt and Israel. The only cause is Carter's efforts to reduce tension in the Middle East, and no consequences are included, other than reaching "a peace agreement early in 1979" (p. 706).

(Holt 1986) Relationships include U.S. Secretary of State Cyrus Vance's efforts; the apparent easing of tensions between Sadat and Begin; high emotions of good will at the signing of the peace treaty; Arab anger at Sadat and criticism of Carter; continued American dependence on Arab oil-exporting nations. The primary cause of Camp David is the stalemate in nine month negotiations prior to Camp David. There is no explanation of how both sides came to agreement, only that they eventually did. Regarding consequences, the following two unresolved issues, or "details" of the treaty that could not be worked out are mentioned: "occupied" Israeli lands and Palestinian demands for a homeland in the West Bank and Gaza. There is mention of Israel's returning the Sinai to Egypt and also of Arab anger at Sadat and criticism of Carter. The ultimate consequence seems to be the continued threat of war in the Middle East.

(PH 1986) Relationships include Sadat and Begin's rocky negotiations; Arab condemnation of Egypt's agreement; and Carter's personal role in negotiations at Camp David. Sadat's willingness to visit Israel and prior breakdowns in peace talks seem to be the primary factors leading to Camp David. Consequences highlighted in the text 
mention that this was the first agreement between an Arab nation and Israel; Israel's return of the Sinai to Egypt; Israel and Egypt's pledge to "work toward a solution to the Palestinian refugee problem"; Arab condemnation of Egypt and eventual assassination of Sadat; and the fact that the Camp David Accords ended thirty years of fighting between Egypt and Israel (p. 708).

(HM 1996) Relationships include the historic antagonism between Egypt and Israel, Sadat's "bold" and "courageous" move to visit Israel, and "intensive discussions" held at Camp David. The only apparent cause leading to Camp David were the prior stalled peace talks. Consequences include "Muslim extremist" threats to Sadat for negotiating with Israel; two separate peace agreements, one of which called for a "five-year transition period during which Israel, Jordan, and the Palestinians would work out the issue of Palestinian self-rule" (p. 914); a second agreement "aimed at ending hostilities between Israel and Egypt" (p. 914); official Egyptian recognition of Israel and return of the Sinai Peninsula; Arab feelings of betrayal toward Sadat; continued PLO terror; and retaliatory raids by Israel on PLO targets in Lebanon.

(Holt 1995) Relationships in this text include Sadat's integral role in peace initiatives, and include personal information about him, such as the influence his childhood Imam and Islamic faith had on him; a quote by Israeli Premier Begin is meant to highlight Begin's admiration of Sadat's courage in visiting Israel; Sadat's belief that his actions were part of "a collective effort by the entire country" (p. 916); as well as mention of the fact that Sadat and Begin shared the Nobel Peace Prize in 1978. The only apparent causes for Camp David seem to be prior failed attempts at peace talks, along with Sadat's recent visit to Israel. Consequences include a shared Nobel Peace Prize in 1978 for Sadat 
and Begin; criticism that Carter favored "the Arabs in order to appease Arab oilexporting nations, such as Saudi Arabia" (p. 916); Arab anger at Sadat; and ultimately, Sadat's assassination "by members of an Islamic fundamentalist group within the Egyptian army" (p. 916).

(PH 1995) The three main relational roles in this text are summarized in the following statement: "At Camp David in September 1978, Carter assumed the role of peacemaker and practiced highly effective personal diplomacy to bridge the gap between Sadat and Begin” (p. 918). Causes for Camp David included the thirty prior years of conflict between Egypt and Israel, the stalled peace talks, and Carter's desire to find a solution. Consequences of Camp David include the settlement that Israel would withdraw from the Sinai, and Egypt would officially recognize the state of Israel; the text also mentions that the Camp David Accords established a process for future peace talks. Like other texts, this edition does recognize that Camp David did not solve all of the problems in the region, among them, "the question of what to do about the Palestinians, many of whom had fled their homes when Arab nations declared war on Israel immediately after that country was established in 1948” (p. 918).

(HM 2003) There are really no obvious relationships in this text, other than implied difficulties between Sadat and Begin because of stalled peace talks, and mention of Carter's "arm twisting" in negotiations at Camp David. Causes for increased American awareness of trouble in the Middle East are from long gasoline lines and higher energy costs that Americans were facing. Causes for Camp David seem to simply be that Carter "seized on the peace initiative" of Sadat and Begin's prior talks in Jerusalem and invited them to Camp David (p. 1022). The primary consequence of Camp David in this text is 
Israel's "first signed peace agreement with an Arab country" (p. 1022). The text does mention that Israel agreed to withdraw from the Sinai in exchange for official recognition from Egypt.

(Holt 2003) Relationships in this text really only include the previous "deadlocked" talks between Sadat and Begin. The cause of Camp David seems to be American fears of more Egyptian-Israeli conflicts. The consequences of Camp David in this text were "a framework for achieving peace in the Middle East", the 1978 Nobel Peace Prize for Sadat and Begin, and Carter's "most gratifying” achievement in his life (p. 1022).

(PH 2005) The three main relational roles in this text are summarized in the following statement: "At Camp David in September 1978, Carter assumed the role of peacemaker. He practiced highly effective personal diplomacy to bridge the gap between Sadat and Begin” (p. 1087). Causes for Camp David included the thirty prior years of conflict between Egypt and Israel, the stalled peace talks, and Carter's desire to find a solution. Consequences of Camp David include the settlement that Israel would withdraw from the Sinai, and Egypt would officially recognize the state of Israel; unlike the last edition, the text does not mention that the Camp David Accords established a process for future peace talks. Like other texts, this edition does recognize that Camp David did not solve all of the problems in the region, among them, "the question of what to do about the Palestinians, many of whom had fled their homes when Arab nations declared war on Israel immediately after that country was established in 1948" (p. 1087).

\section{On what premises is the account based and what assumptions are made in the course of the explanation (Larsen, 1991)?}


(HM 1986) In this text, President Carter was the impetus behind the peace agreement, but the Iranian hostage crisis really trumps the Egypt-Israel peace agreement in this edition (and even in summarizing the hostage crisis, there is no apparent cause in the text for why the hostages were taken, only that they were).

(Holt 1986) The premise in this edition is that the Camp David Accords were an extraordinary step towards peace, but there were still several unresolved issues that could lead to war. A major assumption is that American critics of Carter's Camp David negotiations felt that he "tilted his influence toward the Egyptian-Palestinian side in order to maintain the good will of the Arab oil-exporting nations, particularly Saudi Arabia" (p. 931). Another assumption was the mention that the possibility of war "remained a constant threat" even after the negotiations (p. 931).

(PH 1986) This text's premise includes the statement that the Camp David Accords were "a major breakthrough toward peace", but there were still unresolved issues that had to be addressed for any lasting peace agreement. The book lists the unresolved issues as "Palestinian refugees and occupied lands" (p. 708). From the textual information given, a student would imply that the major point of contention and eventual agreement between Egypt and Israel was the return of the Sinai Peninsula to Egypt. The only other point of negotiation that is mentioned, deals with both nations' agreement to "work toward a solution" for Palestinian refugees. In discussing Arab reaction in particular, the book states: "Other Arab nations condemned Egypt. In the early 1980s, however, there were signs that the more moderate Arab nations might follow Sadat's courageous example" ( $p$. 708). Specific "signs" of moderation are not given though, and considering Egypt's 
expulsion from the Arab League entirely, the preceding statement verges on misleading, if not inaccurate.

(HM 1996) The premise of Camp David in this text is that it was an extension of the temporary agreement Kissinger achieved through shuttle diplomacy, and also an effort to overcome previously stalled peace talks. Assumptions include a textual reference to the Accords as "a detailed peace treaty", while later pointing out that the treaty was ambiguous about the West Bank and Gaza (p. 914); the text claims that "many people were cheered by the news of the treaty"; the text states: "The policy of the U.S. in all this was to provide support for Israel while also trying to find a solution to the Palestinian issues" (p. 914).

(Holt 1995) The premise for this text's account was that the Camp David Accords were Carter's "chief foreign policy triumph" (p. 915). The only obvious assumption is found in the statement: "Sadat always downplayed his own role in bringing about peace" (p. 916); an implicit assumption could include the belief that Sadat played a more active role than Begin in seeking peace.

(PH 1995) The premise of this text is Carter's aim to bring stability and "ethical solutions" to the Middle East through his efforts at Camp David. One of the major assumptions in this text is that prior negotiations between Sadat and Begin failed, only because the two men had "such different personalities" (p. 918). It is also implied that Camp David was a success because of Carter's "highly effective personal diplomacy" (p. 918). Another assumption that some might find controversial in this text is the statement that Arabs "fled" their homes during the 1948 war. 
(HM 2003) The premise of this text's account is that Camp David was Carter's greatest diplomatic achievement, but "that many issues were left unresolved" (p. 1022). The text must assume that students know what these issues are, because they are not included. (Holt 2003) The premise of this text is that Camp David was Carter's greatest foreign policy triumph, his "most gratifying" lifetime achievement, and an agreement that ended "a 30 year state of war between Israel and Egypt" (p.1022). This text's account is so concise, that there are really no obvious assumptions. A major implied assumption, owing to the mention of the Nobel Peace Prize and no other political results of Camp David, is that the negotiations left no unresolved issues.

(PH 2005) The premise of this text can be found in the following opening statement to Camp David: "Although Jimmy Carter had little diplomatic experience when he took office, his personal beliefs greatly influenced his decisions on foreign affairs. Support for human rights was the cornerstone of Carter's foreign policy" (p. 1087). One of the major assumptions in this text is that prior negotiations between Sadat and Begin failed, only because the two men had "such different personalities" (p. 1087). It is also implied that Camp David was a success because of Carter's "highly effective personal diplomacy" ( $p$. 1087). Another assumption that some might find controversial in this text is the statement that Arabs "fled" their homes during the 1948 war.

\section{What perspectives, questions, theories are not acknowledged (Larsen, 1991)?}

(HM 1986) Everything in this text remains unacknowledged with the following exceptions: Carter's motivation and the fact that it was an agreement between Egypt and Israel only. 
(Holt 1986) The following are not included in this text: Sadat's motivations for negotiating; Begin's motivations for negotiating; Carter's motivations for negotiating; Carter's call for a "Palestinian homeland" in March of 1977 is not mentioned; Carter's departure from step-by-step diplomacy and preference for more comprehensive diplomatic action is not mentioned; the conditions for each peace agreement, particularly the avoidance of the dispute surrounding Jerusalem and the Golan Heights is not included; disagreement within the PLO about a compromise Palestinian state in the West Bank and Gaza is not mentioned; reasons why Israel was willing to give up the Sinai, but not the West Bank and/or Gaza is not addressed; Egyptian and American hopes that Jordan would be drawn into the negotiations are not discussed; motivating factors that led Egypt and Israel to make concessions in the negotiations are not included.

(PH 1986) The following are not included in this text: Sadat's motivations for negotiating; Begin's motivations for negotiating; Carter's call for a "Palestinian homeland" in March of 1977 is not mentioned; Carter's departure from step-by-step diplomacy and preference for more comprehensive diplomatic action is not mentioned; the fact that there were two separate agreements, along with the titles for the those agreements, are not mentioned. ("A Framework for Peace in the Middle East" and "A Framework for the Conclusion of a Peace Treaty Between Egypt and Israel"); the conditions for each peace agreement, particularly the avoidance of the dispute surrounding Jerusalem and the Golan Heights is not included; disagreement within the PLO about a compromise Palestinian state in the West Bank and Gaza is not mentioned; the fact that Israel was willing to give up the Sinai or that they eventually did is not mentioned; Egyptian and American hopes that Jordan would be drawn into the 
negotiations are not discussed; motivating factors that led Egypt and Israel to make concessions in the negotiations are not included; Egypt's reaction to the Camp David Accords is not included; the Arab world's reaction to the Camp David Accords is not included; Sadat's assassination is not included; reasons why Sadat was assassinated are not given, as well as who assassinated him.

(HM 1996) It is interesting to note that this text is the first to mention the promises of advanced weaponry as a negotiating tool on the part of the U.S. It was also the first to mention that there were two separate agreements and give some detail for each, as well as mention the threats to Sadat for negotiating with Israel.

The following are not included in this text: Sadat's motivations for negotiating; Begin's motivations for negotiating; Carter's motivations for negotiating; Carter's call for a "Palestinian homeland" in March of 1977 is not mentioned; Carter's departure from step-by-step diplomacy and preference for more comprehensive diplomatic action is not mentioned; the fact that there were two separate agreements, along with the titles for the those agreements, are not mentioned. ("A Framework for Peace in the Middle East" and "A Framework for the Conclusion of a Peace Treaty Between Egypt and Israel"); the conditions for each peace agreement, particularly the avoidance of the dispute surrounding Jerusalem and the Golan Heights is not included; disagreement within the PLO about a compromise Palestinian state in the West Bank and Gaza is not mentioned; reasons why Israel was willing to give up the Sinai, but not the West Bank and/or Gaza is not addressed; Egyptian and American hopes that Jordan would be drawn into the negotiations are not discussed; U.S. reaction to the Camp David Accords is not included; increased Arab suspicion of Israel and the U.S., because of 
Camp David, is not addressed; Sadat's assassination is not included; reasons why Sadat was assassinated are not given, as well as who assassinated him.

(Holt 1995) Two notable "firsts" in this text is the mention that Sadat and Begin shared the 1978 Nobel Peace Prize, as well as specific mention of who was responsible for Sadat's assassination. Items still excluded from the text include: The date when the peace accords were signed; Begin's motivations for negotiating; Carter's motivations for negotiating; Carter's call for a "Palestinian homeland" in March of 1977 is not mentioned; Carter's departure from step-by-step diplomacy and preference for more comprehensive diplomatic action is not mentioned; the fact that there were two separate agreements, along with the titles for the those agreements, are not mentioned. (“A Framework for Peace in the Middle East" and "A Framework for the Conclusion of a Peace Treaty Between Egypt and Israel"); specific conditions for each peace agreement; the avoidance of the dispute surrounding Jerusalem and the Golan Heights in the Accords is not included; disagreement within the PLO about a compromise Palestinian state in the West Bank and Gaza is not mentioned; the fact that Israel was willing to give up the Sinai or that they eventually did is not mentioned; reasons why Israel was willing to give up the Sinai, but not the West Bank and/or Gaza is not addressed; Egyptian and American hopes that Jordan would be drawn into the negotiations are not discussed; motivating factors that led Egypt and Israel to make concessions in the negotiations are not included; Egypt's reaction to the Camp David Accords is not included; increased Arab suspicion of Israel and the U.S., because of Camp David, is not addressed.

(PH 1995) The following is not included in this text: The date is not given for when the peace accords were signed; how long the negotiations lasted at Camp David; Sadat's 
motivations for negotiating; Begin's motivations for negotiating; Carter's call for a "Palestinian homeland" in March of 1977 is not mentioned; Carter's departure from stepby-step diplomacy and preference for more comprehensive diplomatic action is not mentioned; the fact that there were two separate agreements, along with the titles for the those agreements, are not mentioned. ("A Framework for Peace in the Middle East" and "A Framework for the Conclusion of a Peace Treaty Between Egypt and Israel"); specific conditions for each peace agreement; the avoidance of the dispute surrounding Jerusalem and the Golan Heights in the Accords is not included; disagreement within the PLO about a compromise Palestinian state in the West Bank and Gaza is not mentioned; reasons why Israel was willing to give up the Sinai, but not the West Bank and/or Gaza is not addressed; Egyptian and American hopes that Jordan would be drawn into the negotiations are not discussed; motivating factors that led Egypt and Israel to make concessions in the negotiations are not included; Egypt's reaction to the Camp David Accords is not included; U.S. reaction to the Camp David Accords is not included; the Arab world's reaction to the Camp David Accords is not included; increased Arab suspicion of Israel and the U.S., because of Camp David, is not addressed; Sadat's assassination is not included; reasons why Sadat was assassinated are not given, as well as who assassinated him.

(HM 2003) The date is not given for when the peace accords were signed; any acknowledgment of who initiated the peace process; reasons why previous peace talks failed; how long the negotiations lasted at Camp David; Sadat's motivations for negotiating; Begin's motivations for negotiating; Carter's motivations for negotiating; Carter's call for a "Palestinian homeland" in March of 1977 is not mentioned; Carter's 
departure from step-by-step diplomacy and preference for more comprehensive diplomatic action is not mentioned; the fact that there were two separate agreements, along with the titles for the those agreements, are not mentioned. ("A Framework for Peace in the Middle East" and "A Framework for the Conclusion of a Peace Treaty Between Egypt and Israel"); specific conditions for each peace agreement; the avoidance of the dispute surrounding Jerusalem and the Golan Heights in the Accords is not included; disagreement within the PLO about a compromise Palestinian state in the West Bank and Gaza is not mentioned; reasons why Israel was willing to give up the Sinai, but not the West Bank and/or Gaza is not addressed; Egyptian and American hopes that Jordan would be drawn into the negotiations are not discussed; motivating factors that led Egypt and Israel to make concessions in the negotiations are not included; Egypt's reaction to the Camp David Accords is not included; U.S. reaction to the Camp David Accords is not included; the Arab world's reaction to the Camp David Accords is not included; increased Arab suspicion of Israel and the U.S., because of Camp David, is not addressed; Sadat's assassination is not included; reasons why Sadat was assassinated are not given, as well as who assassinated him; issues left unresolved by Camp David are not included.

(Holt 2003) The following is not included in this text: The date is not given for when the peace accords were signed; any acknowledgment of who initiated the peace process; reasons why previous peace talks failed; Sadat's motivations for negotiating; Begin's motivations for negotiating; Carter's motivations for negotiating; Carter's call for a "Palestinian homeland" in March of 1977 is not mentioned; Carter's departure from stepby-step diplomacy and preference for more comprehensive diplomatic action is not 
mentioned; the fact that there were two separate agreements, along with the titles for the those agreements, are not mentioned. ("A Framework for Peace in the Middle East" and "A Framework for the Conclusion of a Peace Treaty Between Egypt and Israel”); specific conditions for each peace agreement; the avoidance of the dispute surrounding Jerusalem and the Golan Heights in the Accords is not included; disagreement within the PLO about a compromise Palestinian state in the West Bank and Gaza is not mentioned; the fact that Israel was willing to give up the Sinai or that they eventually did is not mentioned; reasons why Israel was willing to give up the Sinai, but not the West Bank and/or Gaza is not addressed; Egyptian and American hopes that Jordan would be drawn into the negotiations are not discussed; motivating factors that led Egypt and Israel to make concessions in the negotiations are not included; Egypt's reaction to the Camp David Accords is not included; U.S. reaction to the Camp David Accords is not included; the Arab world's reaction to the Camp David Accords is not included; increased Arab suspicion of Israel and the U.S., because of Camp David, is not addressed; Sadat's assassination is not included; reasons why Sadat was assassinated are not given, as well as who assassinated him; issues left unresolved by Camp David are not included. (PH 2005) With the exception of a few less sentences, this edition is nearly identical to the 1995 edition. The following is also not included in this text: The date is not given for when the peace accords were signed; how long the negotiations lasted at Camp David; Sadat's motivations for negotiating; Begin's motivations for negotiating; Carter's call for a "Palestinian homeland" in March of 1977 is not mentioned; Carter's departure from step-by-step diplomacy and preference for more comprehensive diplomatic action is not mentioned; the fact that there were two separate agreements, along with the titles for the 
those agreements, are not mentioned. ("A Framework for Peace in the Middle East" and "A Framework for the Conclusion of a Peace Treaty Between Egypt and Israel"); specific conditions for each peace agreement; the avoidance of the dispute surrounding Jerusalem and the Golan Heights in the Accords is not included; disagreement within the PLO about a compromise Palestinian state in the West Bank and Gaza is not mentioned; reasons why Israel was willing to give up the Sinai, but not the West Bank and/or Gaza is not addressed; Egyptian and American hopes that Jordan would be drawn into the negotiations are not discussed; motivating factors that led Egypt and Israel to make concessions in the negotiations are not included; Egypt's reaction to the Camp David Accords is not included; U.S. reaction to the Camp David Accords is not included; the Arab world's reaction to the Camp David Accords is not included; increased Arab suspicion of Israel and the U.S., because of Camp David, is not addressed; Sadat's assassination is not included; reasons why Sadat was assassinated are not given, as well as who assassinated him.

\section{0s Conflict in Lebanon:}

\section{1. "What are the underlying problems which have generated this discourse" (Larsen, 1991)?}

(HM 1986) N/A

(Holt 1986) Two underlying problems are apparent in this text: first, the text provides context on the Arab world by explaining Sadat's successor in Egypt, Mubarak, had much cooler relations with Israel and began re-establishing ties with Arab nations that had been broken after Camp David; the text begins its discussion of Lebanon specifically, by 
stating that "the Palestinians who had left their land after the founding of Israel in 1948...still wanted to reclaim their lands from Israel” (p. 936).

(PH 1986) Underlying problems in this text are found in the statement that Lebanon is simply "another Middle Eastern trouble spot.... a small country [that] includes different groups of Christians and Muslims" (p. 709).

(HM 1996) Underlying problems in this text include the statements that Camp David did not bring lasting peace to the region, Egypt's new leader, Mubarak, was more “cool toward Israel" than his predecessor Sadat, and Israel continued establishing settlements in the West Bank (p. 937).

\section{(Holt 1995) N/A}

(PH 1995) The underlying problem is found in the simple, opening statement for the subheading "World Trouble Spots", that: "The end of the cold war did not bring peace outside Europe either...[and] the Middle East remained a place of religious tension and chaos" (p. 953-54).

(HM 2003) N/A

(Holt 2003) N/A

(PH 2005) The underlying problem in this text's mention of Lebanon is that the country had become "a battleground for a variety of armed political groups, some backed by neighboring countries" (p. 1106).

\section{What theories provide the descriptions and explanations thought relevant?}

(HM 1986) N/A

(Holt 1986) The predominant theory in this text is that Israel attacked Lebanon because "the best-known and strongest Palestinian group, the Palestine Liberation Organization 
(PLO) was centered there" (p. 936). U.S. involvement, according to this text, stemmed from fears that Israel's attack could lead to "wider war", and U.S. military presence in Lebanon was meant to ensure "the safety of the PLO as it pulled out" (p. 936).

(PH 1986) Theory in this text includes Syria's invasion of Lebanon because of the civil war between religious groups, and Israel's invasion of Lebanon to "drive the PLO out of its bases there" (p. 936). The international peacekeeping force, according to this text, was meant to "restore order in Lebanon" (p. 936).

(HM 1996) Israel's attack, in this text, was on "Palestinian positions in Lebanon" and the U.S. contingent of American marines, in cooperation with the UN, was meant to “ensure the PLO's safety as it withdrew [from Lebanon]" (p. 938).

\section{(Holt 1995) N/A}

(PH 1995) The theory in this text is that Lebanon was simply caught in the middle of the hostilities between Israel and the PLO (although the text does not address exactly how they were caught in the middle, or that Lebanon had their own political problems too), and that the marines Reagan sent to Beirut were part of a peacekeeping force (although it is not explicitly stated between whom the marines were meant to keep the peace).

(HM 2003) N/A

(Holt 2003) N/A

(PH 2005) The predominant theory in this text is that the Middle East was just another international difficulty that the United States had to face during Reagan's term in office.

\section{What relationships, causes, consequences are proposed?}

(HM 1986) N/A 
(Holt 1986) Relationships in this text include: "cooled" relations between Egypt and Israel, U.S. protest of Israeli action in Lebanon, along with American deaths due to terrorism there, and fighting between Christian and Islamic groups in Lebanon. The cause of Israel's invasion is clearly PLO presence in southern Lebanon, in order to "wipe out bases from which the PLO could make raids and to destroy its effectiveness" (p. 936). Consequences include an international force entering Lebanon, in order to "ensure the safety of the PLO as it pulled out [of Lebanon]" (p. 936); public protest in the U.S. over American deaths in Lebanon caused Reagan to promise a pull-out of all troops within eighteen months, and the text goes on to correlate this promise with the bombings of the marine base and American embassy in Lebanon. The ultimate consequence in this text, even after mentioning that Israel pulled its troops back to southern Lebanon, is that "still, peace did not come" (p. 936).

(PH 1986) Relationships in this text include: hostile Christian and Muslim groups in Lebanon; U.S. protest of American involvement in Lebanon; and continued Israeli presence in Lebanon. The cause of civil war in Lebanon is the differing Christian and Muslim groups, and results in Syria's invasion. The cause of Israel's invasion is clearly PLO presence in southern Lebanon. A consequence of Israel's invasion is U.S. disapproval and action through the U.N. to send a peacekeeping force, of which American troops were a part. Ultimately, the peacekeeping force was unsuccessful since the fighting continued and, "almost everyday, bombs exploded in Beirut" (p. 710). A final consequence in this text was the marine barrack bombing and pull-out of troops. (HM 1996) The most predominant relationships include the cooling between Egypt and Israel, and increased Palestinian hostility towards Israel. In this text, Israel's continued 
West Bank settlements seems to be a direct response to and rejection of Reagan's suggestion that Israel cede the West Bank to the Palestinians. In turn, the book states: "This led many Palestinians to fear that Israel meant to annex the West Bank, and antiIsraeli strikes, riots, and suicide bombings became commonplace" (p. 938). The return of UN forces in Lebanon, after successfully evacuating PLO forces from Lebanon, was to stop the fighting between Christian and Muslim groups there. According to the text, this resulted in many Muslims believing that the U.S. was siding with Christians in the conflict. The 1983 bombing of marine barracks in Beirut is seen as a consequence of that belief. In response, Reagan pulled the marines out. Another attack on the US embassy in Beirut, with twelve American deaths is mentioned, but no real cause is identified (other than the continued fighting in Lebanon between Muslims and Christians), and no response by the U.S. is given in the text.

\section{(Holt 1995) N/A}

(PH 1995) Relationships apparent in this text include Lebanon being caught in the middle between the PLO and Israel, Reagan attempting to keep peace in the region, and terrorist attacks directed at the American embassy and marine barracks in Beirut. The only cause of anything in this text seems to be the hostilities between the PLO and Israel. The ultimate consequence is simply that Reagan pulled American forces out of Lebanon due to public pressure resulting from the terrorist attacks.

\section{(HM 2003) N/A}

(Holt 2003) N/A

(PH 2005) There are no apparent relationships in this text. The only cause for Reagan's peacekeeping force in Lebanon is because the country had become home to different 
armed political groups. The terrorist attack on the marine barracks is seen as a direct response to this peacekeeping force, and the ultimate consequence is Reagan's acquiescence to political pressure at home for an immediate withdrawal of all troops in Lebanon.

\section{On what premises is the account based and what assumptions are made in the course of the explanation (Larsen, 1991)?}

(HM 1986) N/A

(Holt 1986) The premise of this text is that Israel was successful in driving the PLO out of Lebanon, but not in obtaining peace. A controversial statement at the beginning of the text is that Palestinians "left their lands" in 1948. Another implicit assumption is found in the phrase, "many former Palestinians had settled in Lebanon", as if there was or ever had been an official state of Palestine. A student could also imply from the text that the PLO, while centered in southern Lebanon, had not yet carried out any attacks on Israel from that location, prior to Israel's attack: "Israel was seeking to wipe out bases from which the PLO could make raids and to destroy its effectiveness" (emphasis added p. 936). It is also interesting to note that the text states the international peacekeeping force was meant to ensure the safety of the PLO, since at this time, America regarded the PLO as a terrorist organization and refused to even open a dialogue with that organization.

(PH 1986) The premise of this text is that ultimately, the fighting in Lebanon accomplished nothing, and America is still working "to get Israel to withdraw its troops from Lebanon [and support] other efforts to bring peace to Lebanon" (p. 710). One implicit assumption is that the civil war in Lebanon was caused only by religious differences among Christian and Muslim populations. 
(HM 1996) The premise of this text is that while Israel was successful in forcing the PLO out of Lebanon, anti-Israeli feelings among the Palestinians only increased, and the fighting continued in Lebanon. One major assumption in this text is that anti-Israeli feelings among the Palestinians were Israel's fault, because of Israeli settlements in the West Bank. Another assumption in this text is that the sole impetus for terrorist attacks on U.S. marines and the U.S. embassy in Beirut was simply the presence of American forces with the UN peacekeeping force in Lebanon.

\section{(Holt 1995) N/A}

(PH 1995) The premise of this text is that tensions between the PLO and Israel required American intervention, and Lebanon was simply caught in the middle. It is implied in the text that the terrorist attacks on the marine barracks and embassy were simply the response to American forces being in Lebanon.

\section{(HM 2003) N/A}

(Holt 2003) N/A

(PH 2005) The premise of this text is that Lebanon required American intervention because of the "variety of armed political groups" there (p. 1106). It is implied in the text that the terrorist attack on the marine barracks was simply a response to American forces being in Lebanon.

5. What perspectives, questions, theories are not acknowledged (Larsen, 1991)? (HM 1986) N/A

(Holt 1986) Perspectives, questions and theories left unacknowledged in this text include: why Egypt-Israeli relations cooled since Camp David; how the PLO came to be centered in Lebanon; who was in charge of the PLO; divided Israeli opinion on the 
invasion of Lebanon; international opinion of Israel's actions in Lebanon; why Syria invaded Lebanon; the tenuous political situation in Lebanon between Christian and Muslim groups, and why Israel and Syria involved themselves in Lebanese politics; what terrorist organization was responsible for the Lebanon marine base and American embassy bombings and what were the motivations of the responsible terrorist group; what, if any other actions, did the U.S. take to secure peace in Lebanon and negotiate with Israel.

(PH 1986) Perspectives, questions and theories left unacknowledged in this text include: why Egypt-Israeli relations cooled since Camp David; how the PLO came to be centered in Lebanon; who was in charge of the PLO; divided Israeli opinion on the invasion of Lebanon; international opinion of Israel's actions in Lebanon; the tenuous political situation in Lebanon between Christian and Muslim groups, and why Israel and Syria involved themselves in Lebanese politics; what terrorist organization was responsible for the Lebanon marine base and American embassy bombings and what were the motivations of the responsible terrorist group; what, if any other actions, did the U.S. take to secure peace in Lebanon and negotiate with Israel.

(HM 1996) Perspectives, questions and theories left unacknowledged in this text include: why Egypt-Israeli relations cooled since Camp David; how the PLO came to be centered in Lebanon; who was in charge of the PLO; divided Israeli opinion on the invasion of Lebanon; U.S. opinion of Israel's actions in Lebanon; international opinion of Israel's actions in Lebanon; why Syria invaded Lebanon; the tenuous political situation in Lebanon between Christian and Muslim groups, and why Israel and Syria involved themselves in Lebanese politics; what terrorist organization was responsible for the 
Lebanon marine base and American embassy bombings and what were the motivations of the responsible terrorist group; what, if any other actions, did the U.S. take to secure peace in Lebanon and negotiate with Israel.

\section{(Holt 1995) N/A}

(PH 1995) Perspectives, questions and theories left unacknowledged in this text include: no mention Egypt-Israeli relations since Camp David; how the PLO came to be centered in Lebanon; who was in charge of the PLO; this is the first text to exclude the fact that Israel even invaded Lebanon; divided Israeli opinion on the invasion of Lebanon; U.S. opinion of Israel's actions in Lebanon; international opinion of Israel's actions in Lebanon; why Syria invaded Lebanon; the tenuous political situation in Lebanon between Christian and Muslim groups, and why Israel and Syria involved themselves in Lebanese politics; what terrorist organization was responsible for the Lebanon marine base and American embassy bombings and what were the motivations of the responsible terrorist group; what, if any other actions, did the U.S. take to secure peace in Lebanon and negotiate with Israel.

(HM 2003) N/A

\section{(Holt 2003) N/A}

(PH 2005) Syria, the PLO, or Israel are not even mentioned by name is this text's discussion of Lebanon, and this is also the first text not to mention any bombings of the American embassy in Lebanon, or that American forces were part of a larger UN peacekeeping effort. Like other texts, perspectives, questions and theories also left unacknowledged include: no mention of Egypt-Israeli relations since Camp David; how the PLO came to be centered in Lebanon; who was in charge of the PLO; the fact that 
Israel even invaded Lebanon; divided Israeli opinion on the invasion of Lebanon; U.S.

opinion of Israel's actions in Lebanon; international opinion of Israel's actions in Lebanon; why Syria invaded Lebanon; the tenuous political situation in Lebanon between Christian and Muslim groups, and why Israel and Syria involved themselves in Lebanese politics; what terrorist organization was responsible for the Lebanon marine base bombing and what were the motivations of the responsible terrorist group; what, if any other actions, did the U.S. take to secure peace in Lebanon and negotiate with Israel.

\section{1-1994 Peace Talks:}

\section{1. "What are the underlying problems which have generated this discourse" (Larsen, 1991)?}

(HM 1996) There are no underlying problems in this text, except perhaps the mention of President Clinton's lack of foreign policy experience at the beginning of the text's section on Clinton's “Foreign Policy Accomplishments", which the peace accords helped him to overcome (p. 962).

(Holt 1995) The only underlying problem apparent in the text is found in the opening statement of the section "Regional Conflicts": "As the threat of global war between nuclear-armed superpowers fades, regional conflicts have intensified" (p.960).

(PH 1995) There are three underlying problems apparent in this text: first, President Bush's "patient diplomacy had failed to bring the long-sought peace settlement to the region"; second, the PLO and Israel were "weary of the constant fighting"; third, the peace process was exceptionally difficult since the Israelis and Palestinians had been enemies for so long (p. 968).

(HM 2003) N/A 
(Holt 2003) In this text, there are no underlying problems that lead to the peace agreements, however, all of the problems seem to come after the signing, and all the reasons the text lists for continued violence ("violence" is used three times in the eight sentences that describe events after the signing), is due to actions taken by Israel.

(PH 2005) The general underlying problem can be found in the opening statements of the section titled, "Post-Cold War Conflicts": The [U.S.] government had to balance Americans' desire to promote peace with their fear of costly commitments - a fear magnified by memories of the Vietnam War" (p. 1135). Specific to the Arab-Israeli conflict and the 1993 peace agreement is the statement: "Radicals on both sides, however, tried to destroy the agreement by carrying out terrorist attacks" (p. 1137).

\section{What theories provide the descriptions and explanations thought relevant?}

(HM 1996) One theory is that the September 1993 peace talks were an outgrowth of the 1991 Madrid Conference talks on Middle East peace (although it is not mentioned that the PLO was not invited to the Madrid Conference). Another implicit theory is that the Palestinians were willing to participate in the agreements because the U.S. promised financial assistance to the PLO.

(Holt 1995) The predominant theory in this text is that Arafat's and Rabin's peace agreement renewed hope in the Middle East and in the U.S. that peace between Israelis and Palestinians was possible.

(PH 1995) The predominant theory in this text is that Israel's seizure of the Gaza Strip and West Bank after the 1967 war created "virtual war zones" of constant fighting, of which both sides had become tired of defending.

(HM 2003) N/A 
(Holt 2003) The theory for this text, found at the beginning of the text section on "Foreign and Domestic Dangers", is simply that the Middle East, along with an increase in international terrorism, was just another of the many challenges that the Clinton administration had to face.

(PH 2005) The predominant theory in this text is that despite the 1993 agreement, ArabIsraeli peace efforts were beset by "radicals on both sides", and the inability "to solve all the remaining issues, such as control of the holy city of Jerusalem" (p. 1137).

\section{What relationships, causes, consequences are proposed?}

(HM 1996) Relationships include a picture of Rabin and Arafat shaking hands as Clinton looks on; mention of a personal letter from the King of Jordan to President Clinton expressing his desire for peace in the region and Clinton's responding promise of "full support". There are no apparent causes for the peace agreements—-just factual statements that they occurred. Consequences mentioned in the text include U.S. financial assistance to the PLO, the resumption of U.S. military aid to Jordan and the wiping of Jordan's $\$ 700$ million debt to the U.S., and hostility towards Arafat from "Islamic militants in Gaza" (p. 962).

(Holt 1995) The only relationships apparent in this text include the agreement between Arafat and Rabin, and Clinton's overseeing of the signing of the accord. Causes of the peace agreement are not addressed. The only consequence of the agreement, in this text, seems to be a short-lived optimism for peace that was dashed by “ .... Jewish gunman [who] opened fire on Muslim worshipers in the West Bank...” (p. 960).

(PH 1995) Relationships apparent in this text include the "prickly process" of peace between Israelis and Palestinians, challenges to Arafat's authority from within the PLO, 
and arguing between Rabin and Arafat over border crossings. Causes of the peace agreement seem to be the weariness of both sides in fighting over the Gaza Strip and West Bank, and the PLO's willingness to officially recognize Israel's right to exist. Consequences of the agreement were "renewed violence [from] radical Palestinian groups and some Israelis" to show their disapproval, challenges to Arafat's authority from within the PLO who killed Israelis in terrorist attacks, a massacre of more than forty Palestinians in Hebron, and continued arguing between Rabin and Arafat over unsettled issues of the peace agreement. Ultimately, the text states: "Months after the deadline for the withdrawal of Israeli troops...Israeli-Palestinian relations hung in a highly uncertain balance" (p. 969).

\section{(HM 2003) N/A}

(Holt 2003) Relationships include the peace agreement between Arafat and Rabin and Clinton's involvement (although specifics of his involvement are not mentioned, only a picture of him facilitating a handshake between Arafat and Rabin). There seem to be no causes for the peace agreement, only that it was another in a long line of peace efforts in the Middle East. Causes of violence after the peace agreement are clearly Israel's fault in this text: the assassination of Rabin by an "Israeli with extreme nationalist views", Netanyahu's election as Israeli prime minister and the text's statement that he was "less willing to compromise in peace negotiations", and Ariel Sharon's visit to a "contested religious site in east Jerusalem" (p. 1074). Consequences, or results of that peace agreement were that Israel and the PLO formally recognized one another, and "set guidelines for Palestinian self-rule in occupied areas of Israel” (p. 1074). The ultimate consequence in this text is simply: "Violence continued in the area" (p. 1074). 
(PH 2005) Most of the relational information in this text is commentary on Israeli prime ministers. The text states that the 1993 peace agreement "was an extremely difficult step" for both Arafat and Rabin, although it is left to the student to assume why, based on the rest of the information in the text. Israeli prime minister Ehud Barak is described in the text as calling "for a greater commitment to peace talks", and his successor, Ariel Sharon is described as "a fierce critic of the concessions Israel had made in the search for peace" (p. 1137). The ultimate consequences include continued violence, with Rabin's assassination, increased Palestinian terrorist attacks on Israeli "restaurants, buses, and other public places", and Israeli military strikes on Palestinian targets, "often killing civilians in the process" (p.1137).

\section{On what premises is the account based and what assumptions are made in the course of the explanation (Larsen, 1991)?}

(HM 1996) The underlying premise of this text seems to be that the peace agreements were a major foreign policy achievement for President Clinton, and would promote economic development in the Middle East. Implicit assumptions include that Arafat and Rabin signed the peace agreement themselves, when in fact, they did not; that the Palestinians may have been cooperating only to gain financial assistance from the U.S.; and that the "other issues" of negotiations that were left for a later date might be easily worked out since a framework for peace was already begun (962).

(Holt 1995) The premise of this account is that the peace agreements "capped years of efforts to bring peace to the Middle East" (p. 960). Two implicit assumptions are that Arafat and Rabin signed the agreement themselves, and that the only reason for violence 
following the peace accords was due to a Jewish gunman's attack on Muslim worshipers in the West Bank (p. 960).

(PH 1995) The premise of this account is that the peace agreements were "more progress in the quest for stability [in] the Middle East", but that the future peace of the region was still in question (p. 968). Implicit assumptions include that Rabin and Arafat signed the agreement themselves, that both sides were weary of fighting over the Gaza Strip and West Bank and ready to make concessions, and that the source of continued conflict in the region was due to Israeli forces not honoring the withdrawal deadlines set forth in the peace agreements.

\section{(HM 2003) N/A}

(Holt 2003) The premise of this text is that that the peace process was on track with Arafat and Rabin's agreement, but "suffered a setback" with Rabin's assassination, Netanyahu's election, and Sharon's visit to a “contested religious site" (p. 1074). Like other texts, the implicit assumption is that Sharon and Arafat signed the peace agreement themselves. Another implication is that there were no outstanding issues of contention left after the 1993 peace accord.

(PH 2005) The premise of this text is that the 1993 agreement was another hope for peace that "faded rapidly as violence again increased" (p. 1137). Like other texts, the implicit assumption is that Sharon and Arafat signed the peace agreement themselves.

\section{What perspectives, questions, theories are not acknowledged (Larsen, 1991)?}

(HM 1996) The following perspectives, questions, and theories are left unacknowledged in this text: No historical context (particularly the end of the Cold War and how it resulted in the PLO losing its financial sponsor in the Soviet Union; the Persian Gulf 
War) for the peace talks; no mention that there were prior secret meetings between PLO and Israeli leaders; no mention of the "Oslo Accord" or "Declaration of Principles" by name; no mention of what Israel conceded in signing the agreement (withdrawal of forces the West Bank, limiting further settlement in the West Bank); no mention of what the PLO conceded in signing the agreement (formal recognition of Israel); no mention that Rabin and Arafat did not actually sign the agreement themselves; no mention of specific issues of contention left unresolved by the agreement; no mention of Jordan's motivations for negotiating a separate peace with Israel; no mention of Israeli reaction to the agreement; no mention of Palestinian division between the PLO, Fatah, and Hamas; no mention of increased terrorist attacks against Israel after the signing; no mention of Rabin's assassination; no mention of who assassinated Rabin and why.

(Holt 1995) The following perspectives, questions, and theories are left unacknowledged in this text: No historical context (particularly the end of the Cold War and how it resulted in the PLO losing its financial sponsor in the Soviet Union; the Persian Gulf War) for the peace talks; no mention that there were prior secret meetings between PLO and Israeli leaders; no mention of the "Oslo Accord" or "Declaration of Principles" by name; no mention of what Israel conceded in signing the agreement (withdrawal of forces from Gaza and the West Bank, limiting further settlement in the West Bank, and affirmation of Palestinian right to self-government through the creation of the Palestinian Authority); no mention of what the PLO conceded in signing the agreement (formal recognition of Israel and responsibility for security in areas the Israeli Defense Force evacuated); no mention that Rabin and Arafat did not actually sign the agreement themselves; no mention of specific issues of contention left unresolved by the agreement; 
no mention of Jordan's separate peace agreement with Israel; no mention of Jordan's motivations for negotiating a separate peace with Israel; no mention of Palestinian reaction to the agreement; no mention of Palestinian division between the PLO, Fatah, and Hamas; no mention of increased terrorist attacks against Israel after the signing; no mention of Rabin's assassination; no mention of who assassinated Rabin and why. (PH 1995) The following perspectives, questions, and theories are left unacknowledged in this text: no historical context (particularly the end of the Cold War and how it resulted in the PLO losing its financial sponsor in the Soviet Union; the Persian Gulf War) for the peace talks; no mention of the "Oslo Accord" or "Declaration of Principles" by name; no mention of what Israel conceded in signing the agreement (limiting further settlement in the West Bank, and affirmation of Palestinian right to self-government); no mention of what the PLO conceded in signing the agreement (responsibility for security in areas the Israeli Defense Force evacuated); no mention that Rabin and Arafat did not actually sign the agreement themselves; no mention of Jordan's separate peace agreement with Israel; no mention of Jordan's motivations for negotiating a separate peace with Israel; no mention of U.S. reaction to the agreement; no mention of Palestinian division between the PLO, Fatah, and Hamas; no mention of Rabin's assassination; no mention of who assassinated Rabin and why.

\section{(HM 2003) N/A}

(Holt 2003) The following perspectives, questions, and theories are left unacknowledged in this text: No historical context (particularly the end of the Cold War and how it resulted in the PLO losing its financial sponsor in the Soviet Union; the Persian Gulf War) for the peace talks; no mention that there were prior secret meetings between PLO 
and Israeli leaders; no mention of the "Oslo Accord" or "Declaration of Principles" by name; no mention of what Israel conceded in signing the agreement (withdrawal of forces from Gaza and the West Bank, limiting further settlement in the West Bank); no mention of what the PLO conceded in signing the agreement (responsibility for security in areas the Israeli Defense Force evacuated); no mention that Rabin and Arafat did not actually sign the agreement themselves; no mention of specific issues of contention left unresolved by the agreement; no mention of Jordan's separate peace agreement with Israel; no mention of Jordan's motivations for negotiating a separate peace with Israel; no mention of Israeli reaction to the agreement; no mention of Palestinian reaction to the agreement; no mention of Palestinian division between the PLO, Fatah, and Hamas; no mention of increased terrorist attacks against Israel after the signing. This is the first text to mention Sharon's controversial visit in Jerusalem, but the text does not mention where specifically he visited, or why it was controversial.

(PH 2005) The following perspectives, questions, and theories are left unacknowledged in this text: No historical context (particularly the end of the Cold War and how it resulted in the PLO losing its financial sponsor in the Soviet Union; the Persian Gulf War) for the peace talks; no mention that there were prior secret meetings between PLO and Israeli leaders; no mention of the "Oslo Accord" or "Declaration of Principles" by name; no mention of what Israel conceded in signing the agreement (withdrawal of forces from Gaza and the West Bank, limiting further settlement in the West Bank); no mention of what the PLO conceded in signing the agreement (responsibility for security in areas the Israeli Defense Force evacuated); no mention that Rabin and Arafat did not actually sign the agreement themselves; no mention of Jordan's separate peace agreement with 
Israel; no mention of Jordan's motivations for negotiating a separate peace with Israel;

no mention of U.S. reaction to the agreement; no mention of Palestinian division between the PLO, Fatah, and Hamas.

\section{Post 9/11 Conflicts:}

\section{1. "What are the underlying problems which have generated this discourse" (Larsen, 1991)?}

(HM 2003) The underlying problem can be found in the opening statement to the text's epilogue on terrorism in the Middle East: "Like Black September, many terrorist organizations have their roots in the Israeli-Palestinian conflict over land in the Middle East" (p. US7).

(Holt 2003) N/A

(PH 2005) The text's commentary on Israel and Palestine continues uninterrupted from events in September 1993 to the 2003 "roadmap" to peace. The underlying problem following the 1993 peace accords, in this text, is Ariel Sharon's election as prime minister in 2001. The text states that Sharon was "a fierce critic of the concession Israel had made in the search for peace" (p. 1137).

\section{What theories provide the descriptions and explanations thought relevant?}

(HM 2003) The predominant theory in this text is that Arab terrorist groups "have sought to prevent a peace settlement between Israel and the Palestinians. They want a homeland for the Palestinians on their own terms, with the most extreme among them denying Israel's right to exist" (p. US7).

(Holt 2003) N/A 
(PH 2005) The predominant theory is that the fading hopes for peace after the 1993 accords were renewed again with the 2003 "roadmap" to peace, proposed by the U.S., E.U., Russia, and the UN.

\section{What relationships, causes, consequences are proposed?}

(HM 2003) This text identifies Arab terrorist organizations as being separate from Palestinians, it mentions that many Muslims feel "widespread Arab anger" at Israel and also at the U.S. for its support of Israel, and the text cites a "continual cycle of violence" between Israel and terrorists. The root cause in this text is the unwillingness or inability to compromise over the land. The goal of some terrorist groups to "eliminate all nonIslamic influences in Muslim countries" through terrorism, in this text, then leads to Israeli reprisal raids on Palestinians. (With the previous text impression that terrorist groups and Palestinians are essentially separate, the text could be confusing to a student reading that Israel carries out reprisal attacks on "Palestinian targets" rather than terrorists.) In this text, the ultimate consequence was Israel's declaration of a "wwar on terrorism,' patterned after the U.S. response to the September 11 attacks" (p. US8).

(Holt 2003) N/A

(PH 2005) Relationships in this text really only include the increase in violence between "Palestinian extremists" and Israel. The sequence of events in this text begins with Sharon's election, stepped up suicide bombings by Palestinian "extremists", and then regular Israeli military strikes on Palestinian "targets, often killing civilians in the process" (p. 1137). The text ends the sequence of events by stating: "Israeli troops reoccupied the West Bank and completely cut off Arafat's headquarters, trapping him in 
his offices" (p. 1138). Israel's 2003 acceptance of the "roadmap" ultimately led to the first formal recognition by Israel of the Palestinians' right to a state.

\section{On what premises is the account based and what assumptions are made in the course of the explanation (Larsen, 1991)?}

(HM 2003) The premise of this text can be found in the closing statement of the text's epilogue section on terrorism in the Middle East: "Moderates in the region believe that the only long-term solution is a compromise between Israel and the Palestinians over the issue of land" (p. US8). Two implicit assumptions include that Palestinians would make peace with Israel if not for terrorist organizations preventing them from doing so, and that the only issue dividing the two sides is the land itself.

\section{(Holt 2003) N/A}

(PH 2005) The premise of this text is that the 2003 roadmap to peace would either be a positive event that "would result in a lasting peace or in yet another disappointment" ( $p$. 1138). An implicit assumption is that both sides approved the three step plan without reservations, for the establishment of a Palestinian state in the West Bank and Gaza.

\section{What perspectives, questions, theories are not acknowledged (Larsen, 1991)?}

(HM 2003) The following perspectives, questions, and theories are left unacknowledged in this text: Israeli perspectives and feelings about terrorism; contention over security, borders, the right of return for Palestinian refugees, and the status of Jerusalem; contextual background information on the terrorist groups the text identifies (Palestine Islamic Jihad, Hamas, and Hizballah) and what their "terms" are for a Palestinian homeland; further U.S. interaction with Arafat, the PLO, and Israeli leaders following the 1993 peace accords. 


\section{(Holt 2003) N/A}

(PH 2005) The following perspectives, questions, and theories are left unacknowledged in this text: no mention of specific terrorist groups in the Middle East, or their various motivations for carrying out attacks against Israel; Israeli perspectives and feelings about terrorism; contention over security, borders, the right of return for Palestinian refugees, and the status of Jerusalem; no mention of what happened to Arafat after Israel had him trapped in his offices in 2002; further U.S. interaction with Arafat, the PLO, and Israeli leaders following the 1993 peace accords; specific terms of the roadmap to peace, ensuing negotiations, and why both sides agreed to it. 


\section{Appendix C}

This appendix contains all charts derived from the following topic matrix. The topic matrix includes number totals for each textbook, category of analysis, and important terms, and is listed by publisher and decade. 


\section{Mandate Period}

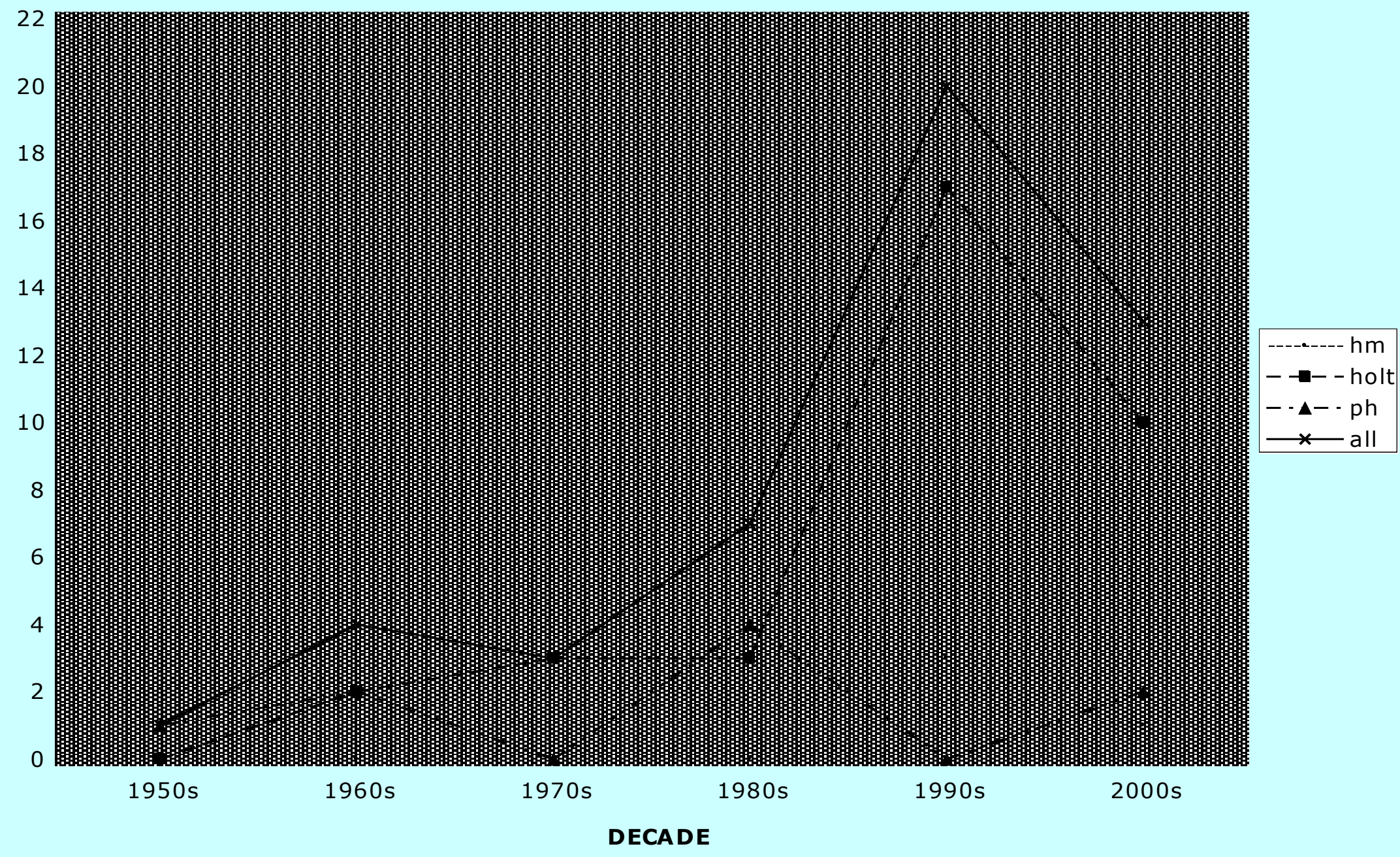


Balfour Dec./1948 War/Est. of Israel

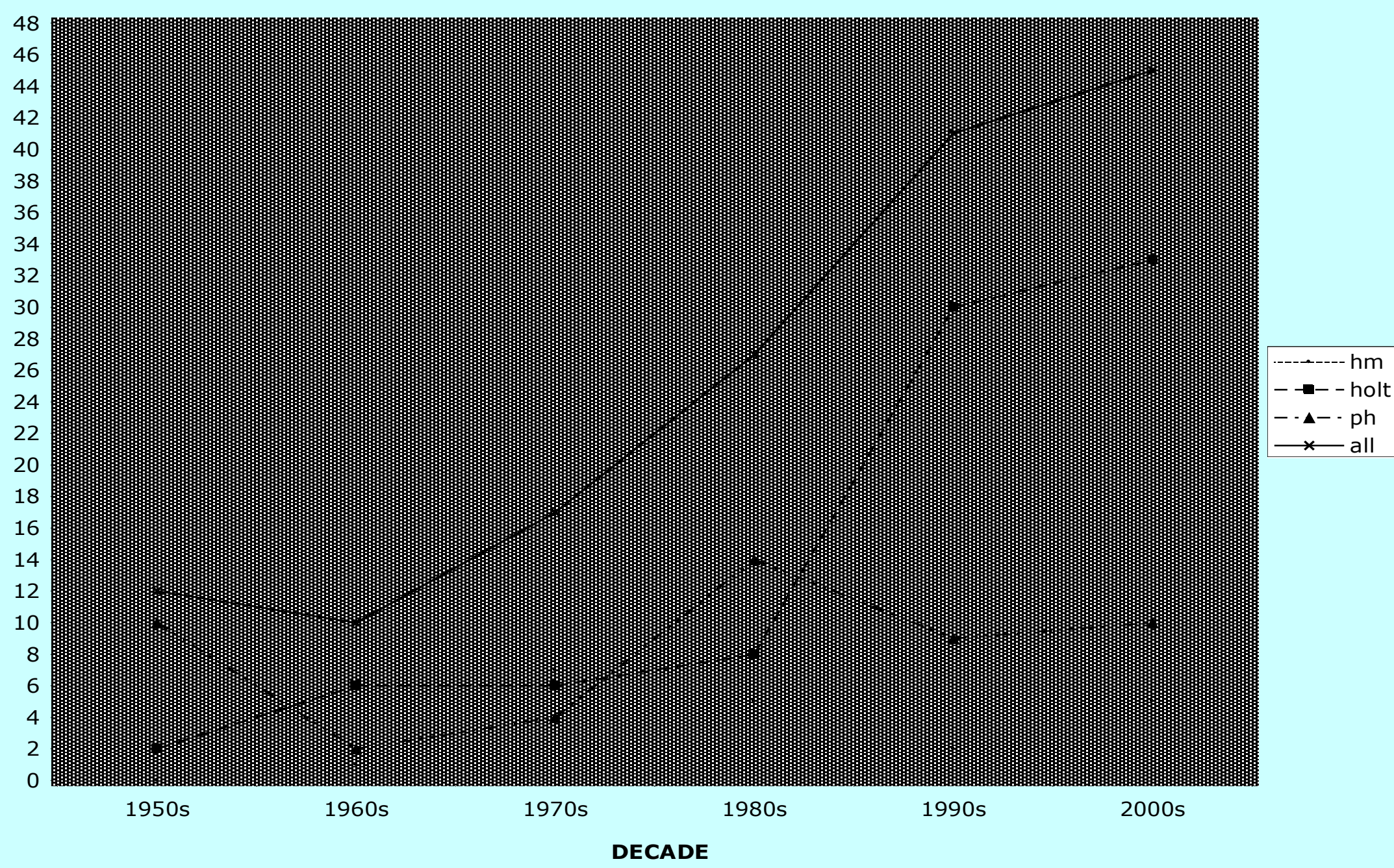




\section{Suez Canal}

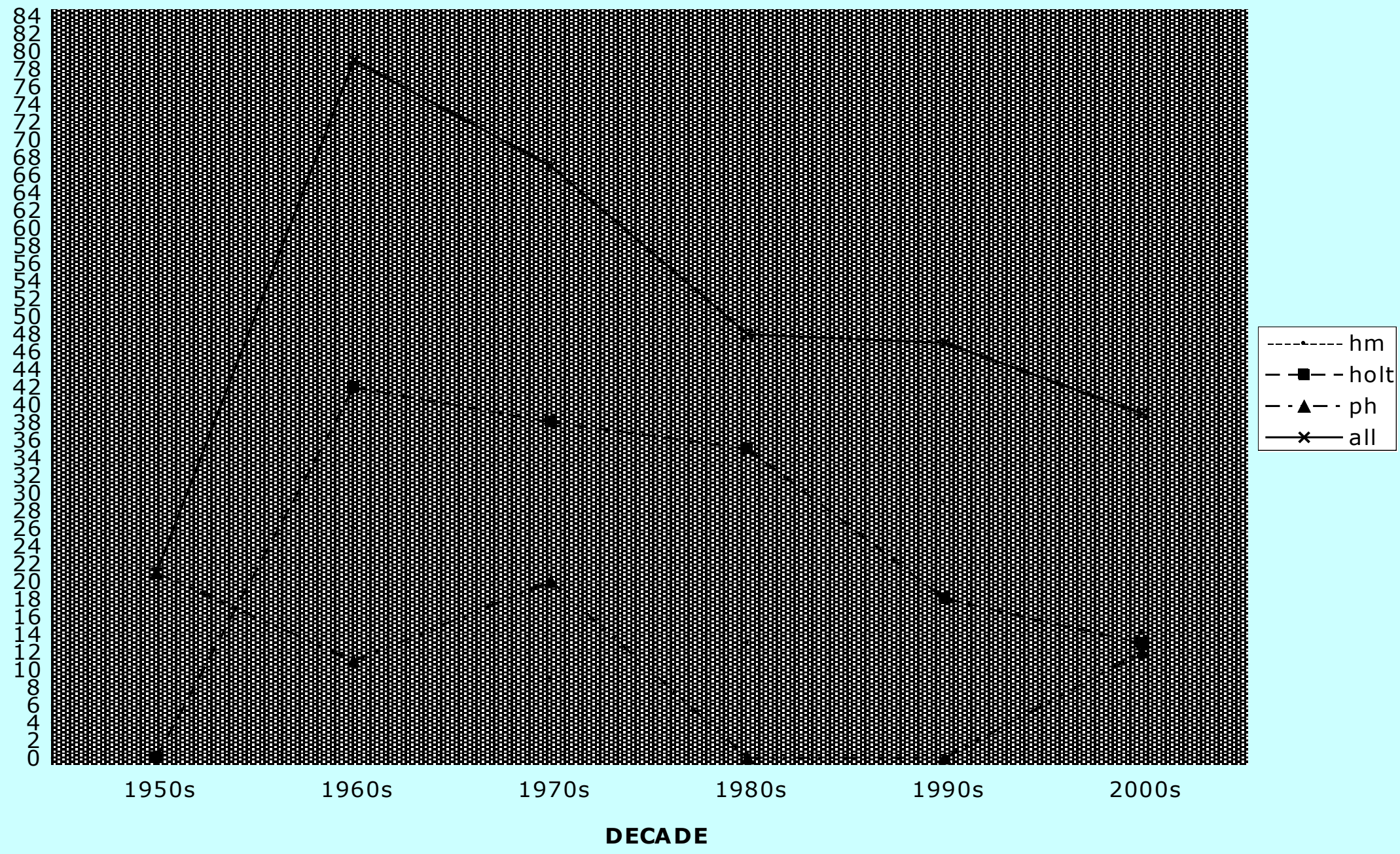




\section{Six Day War}

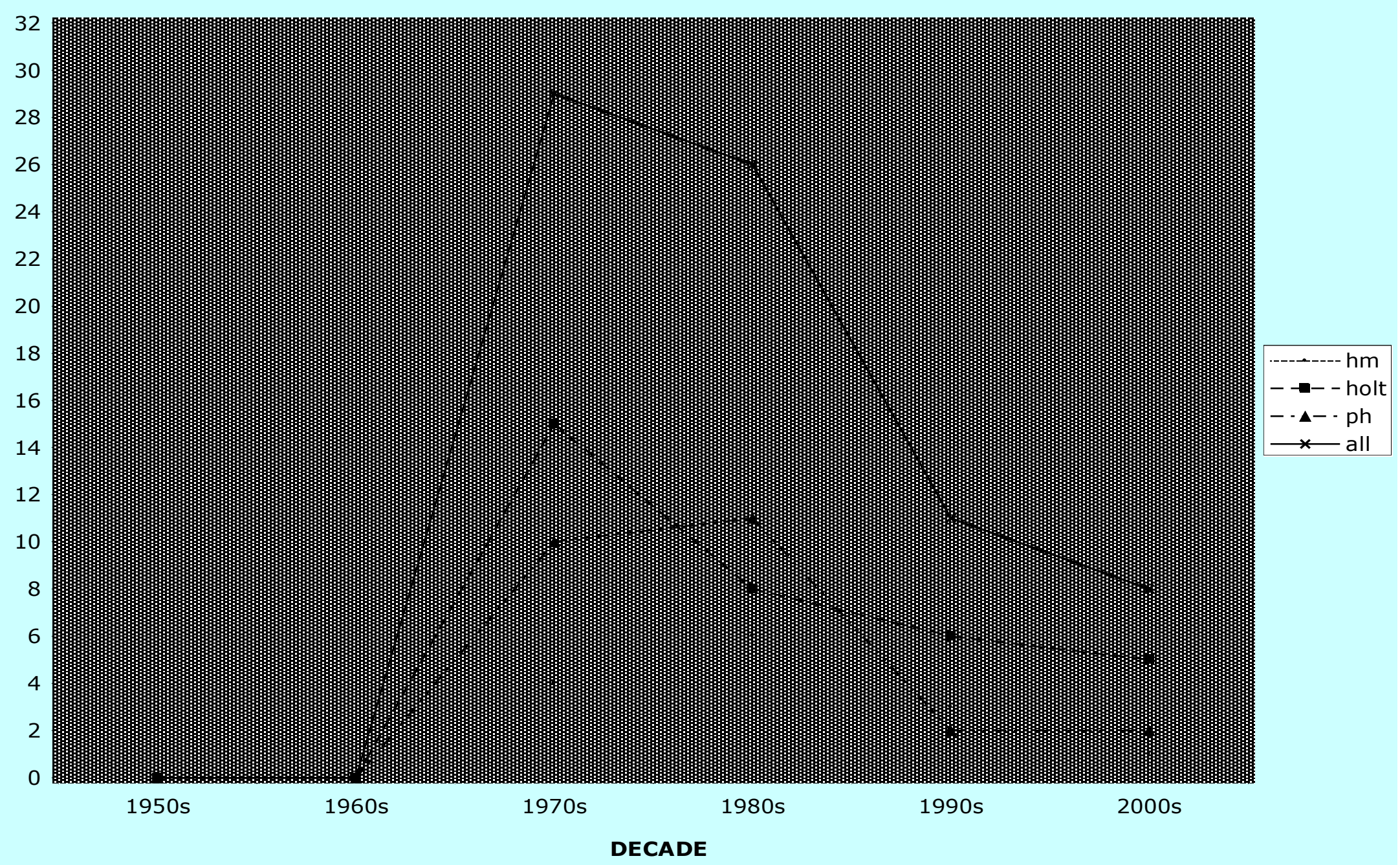




\section{Yom Kippur War}

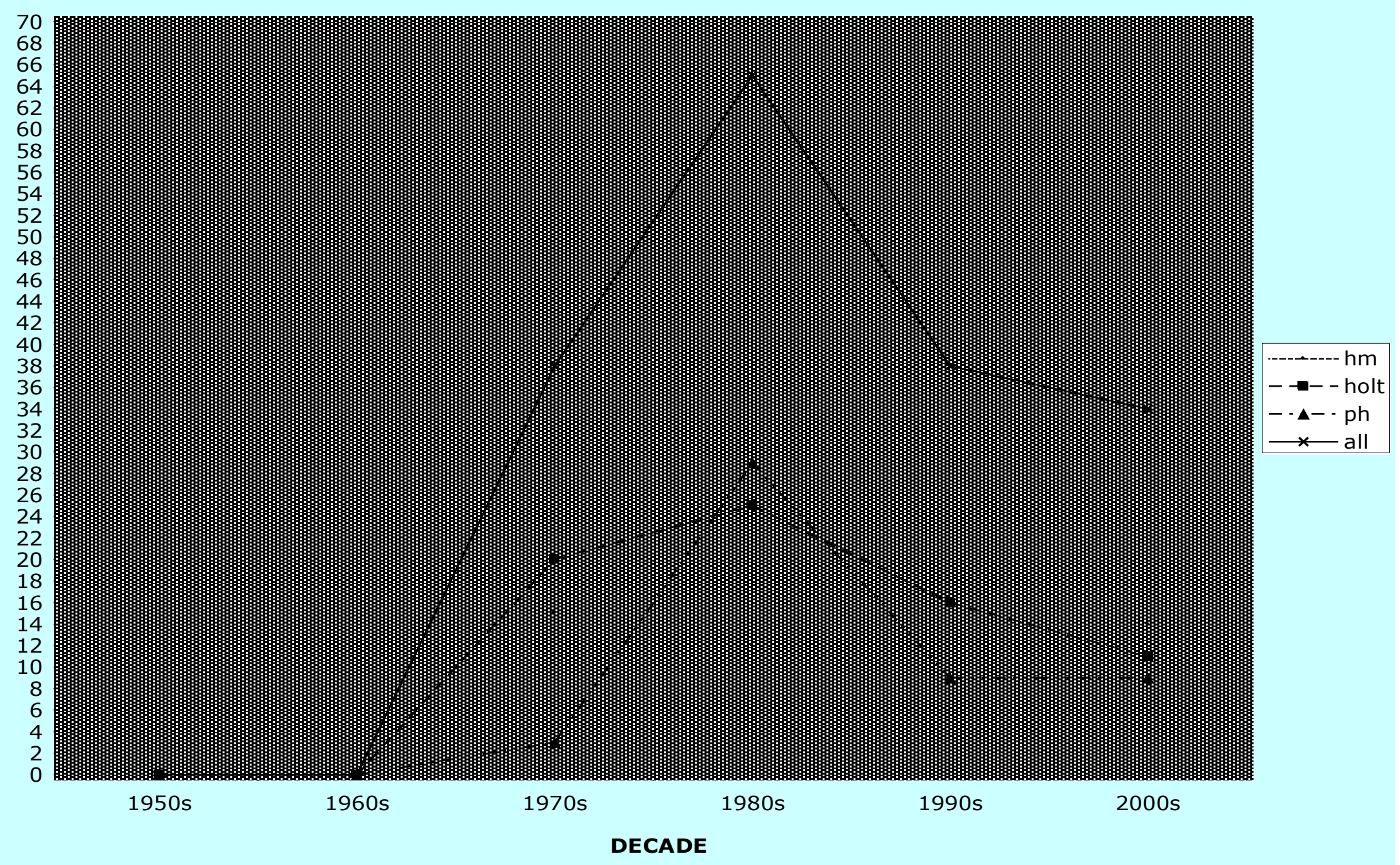




\section{Camp David}

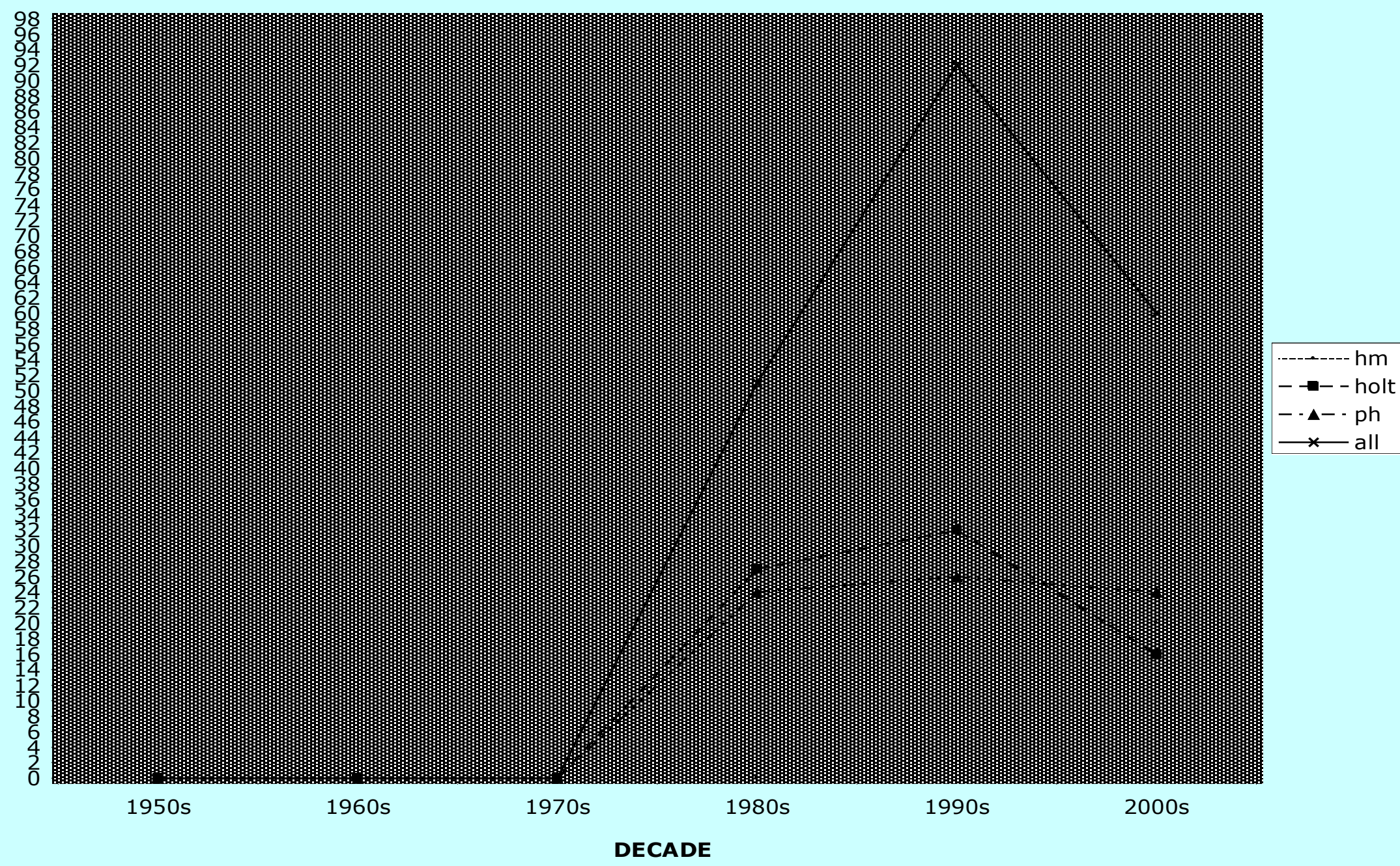




\section{Lebanon}

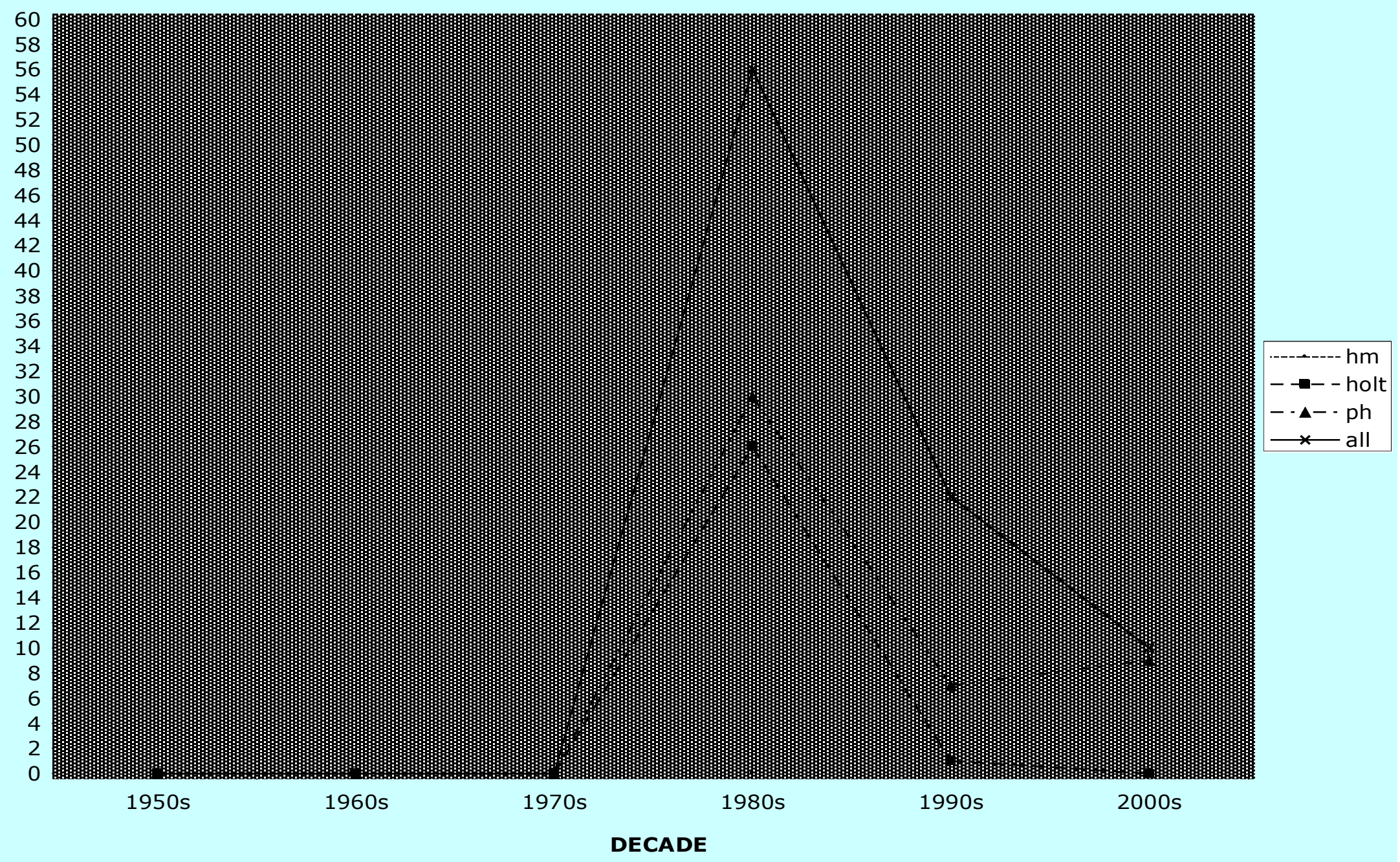


1990s Peace Agreements

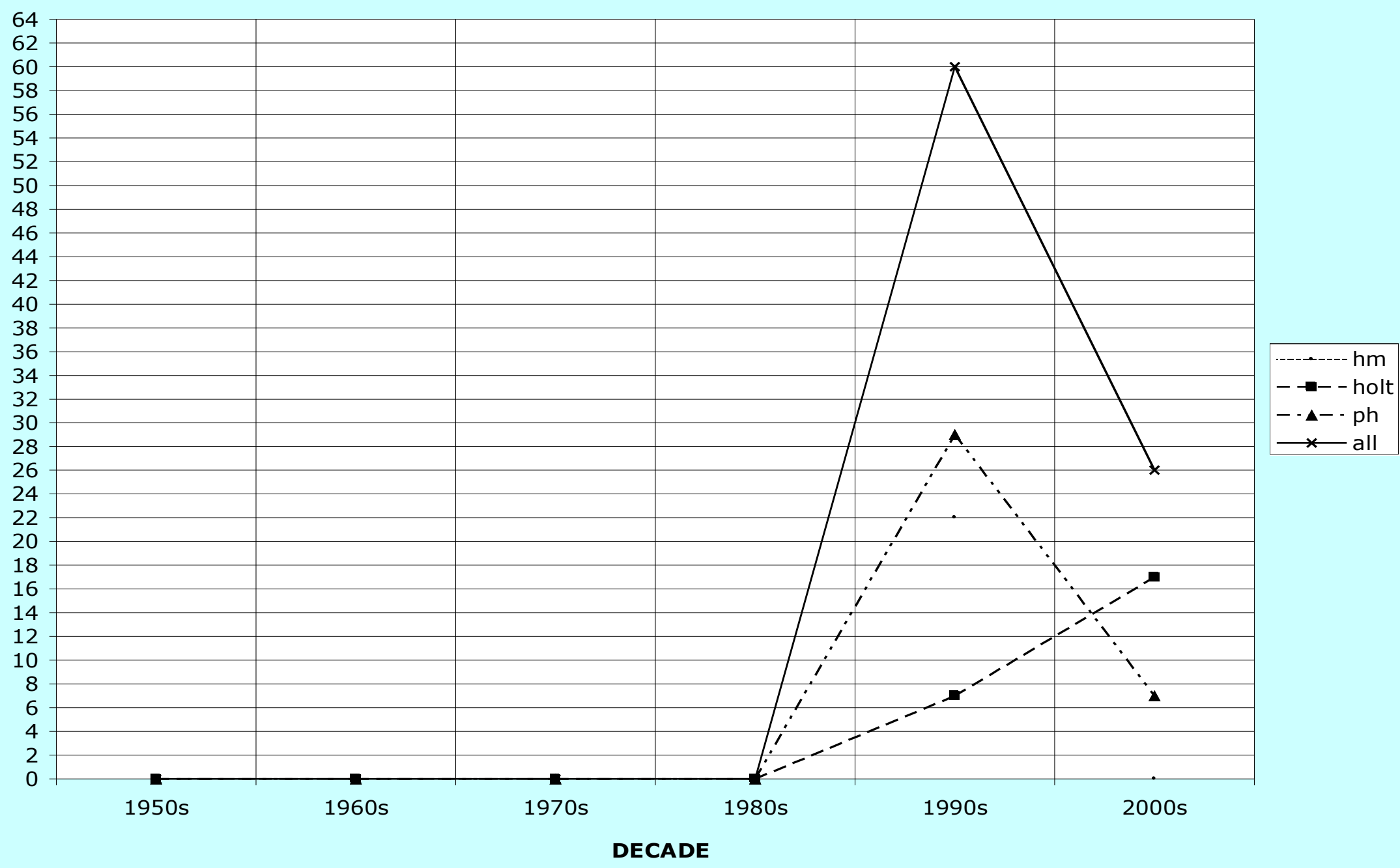




\section{David Ben-Gurion}

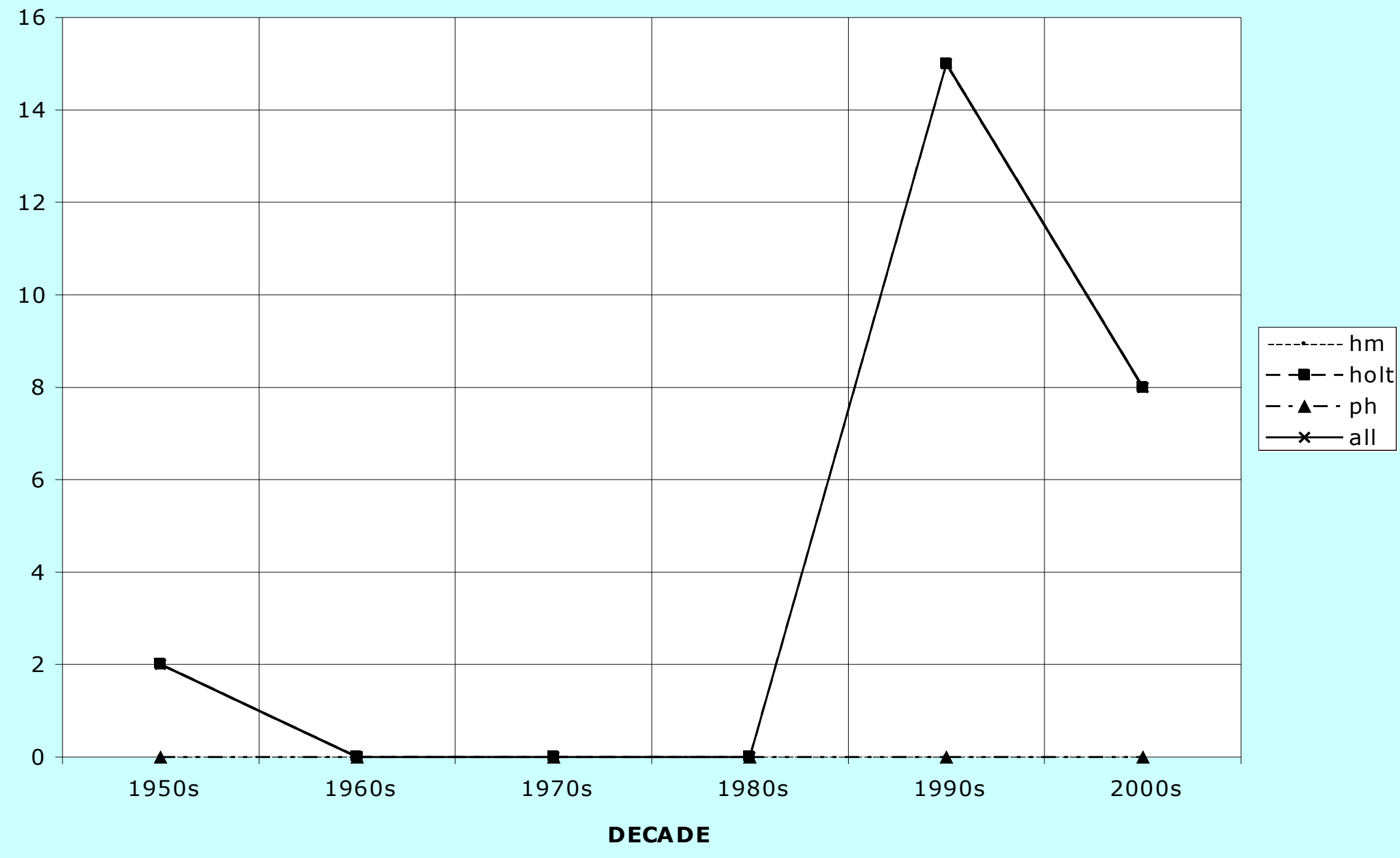




\section{Nasser}

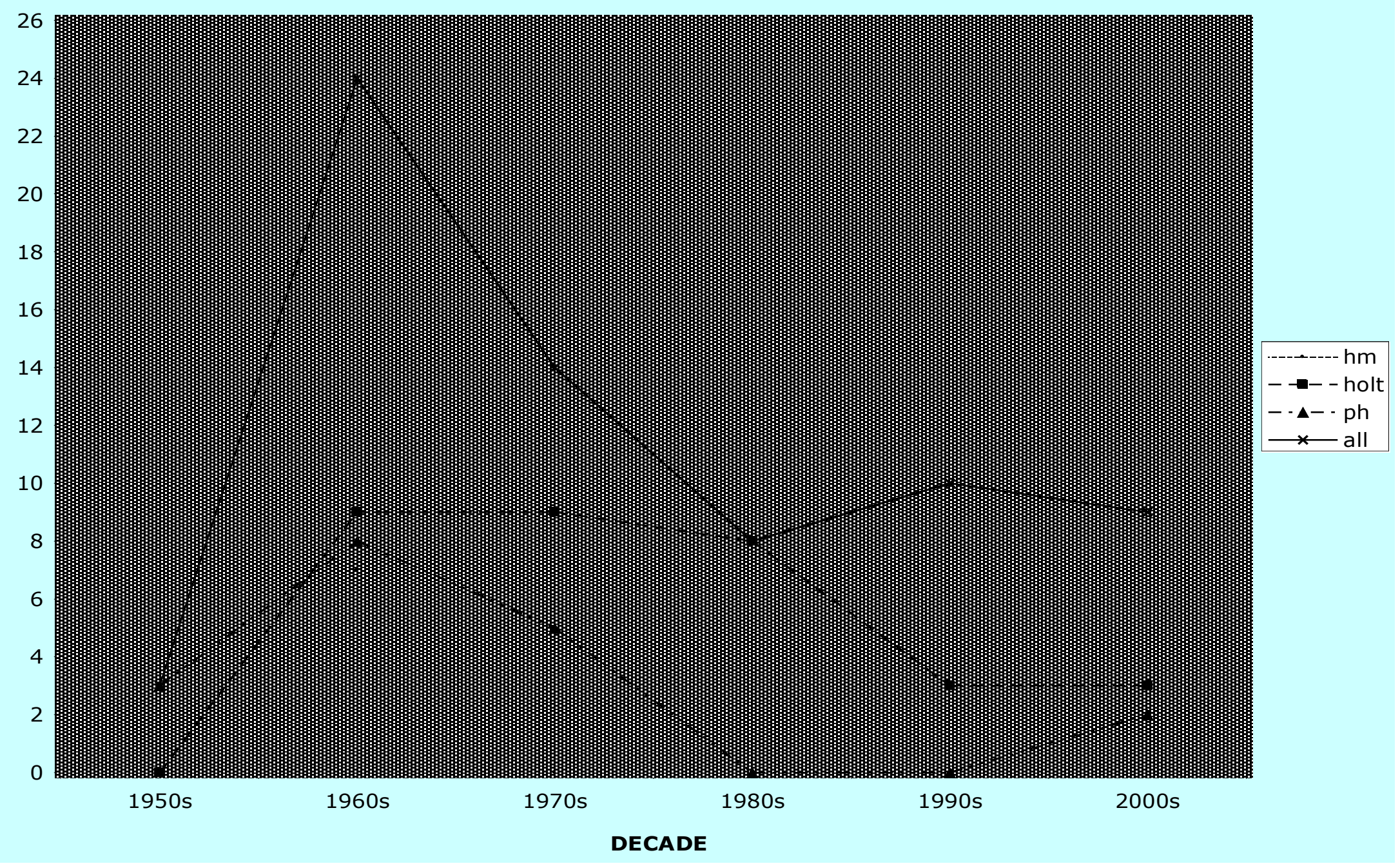




\section{"Arab"}

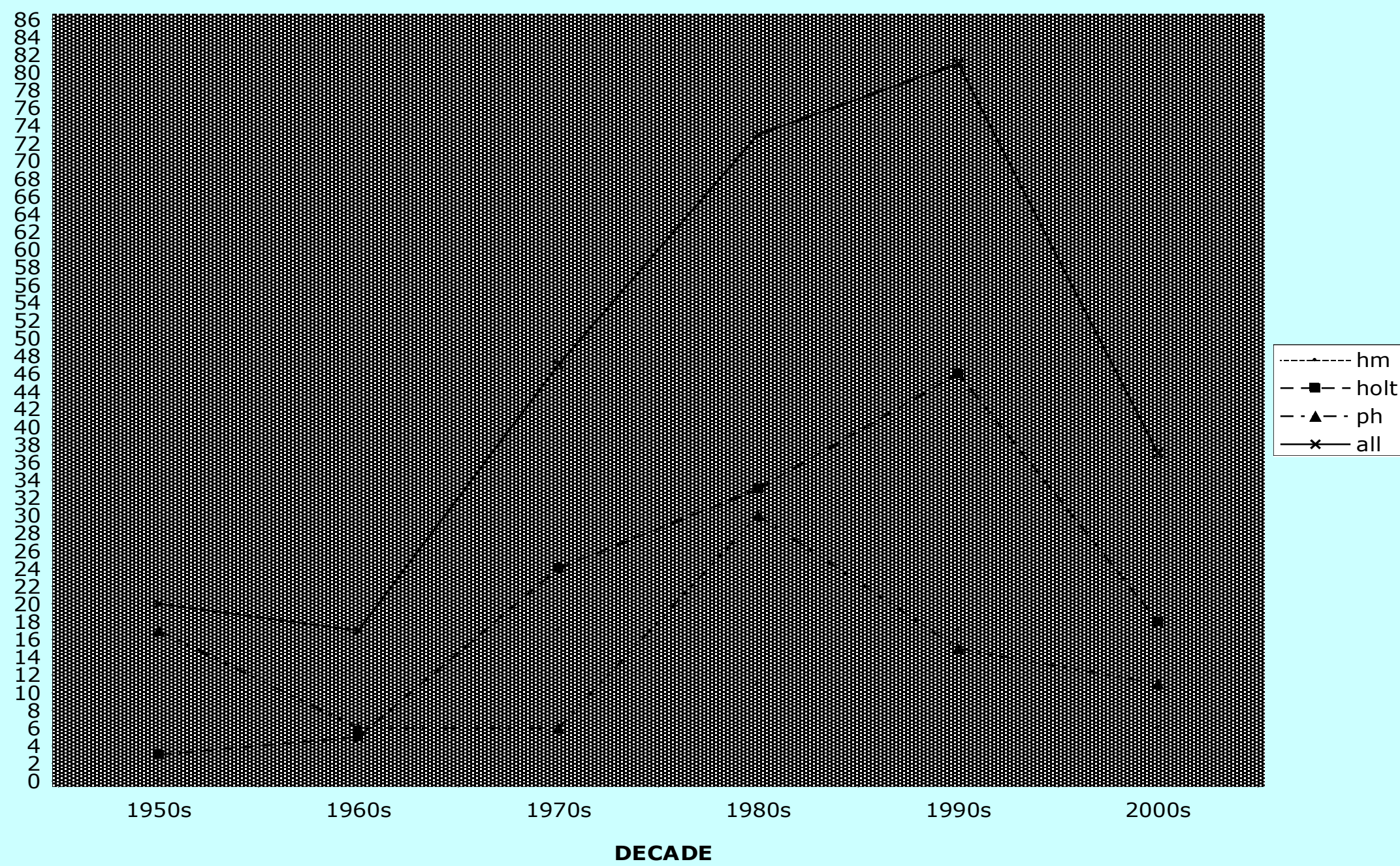




\section{"Israel/Israeli"}

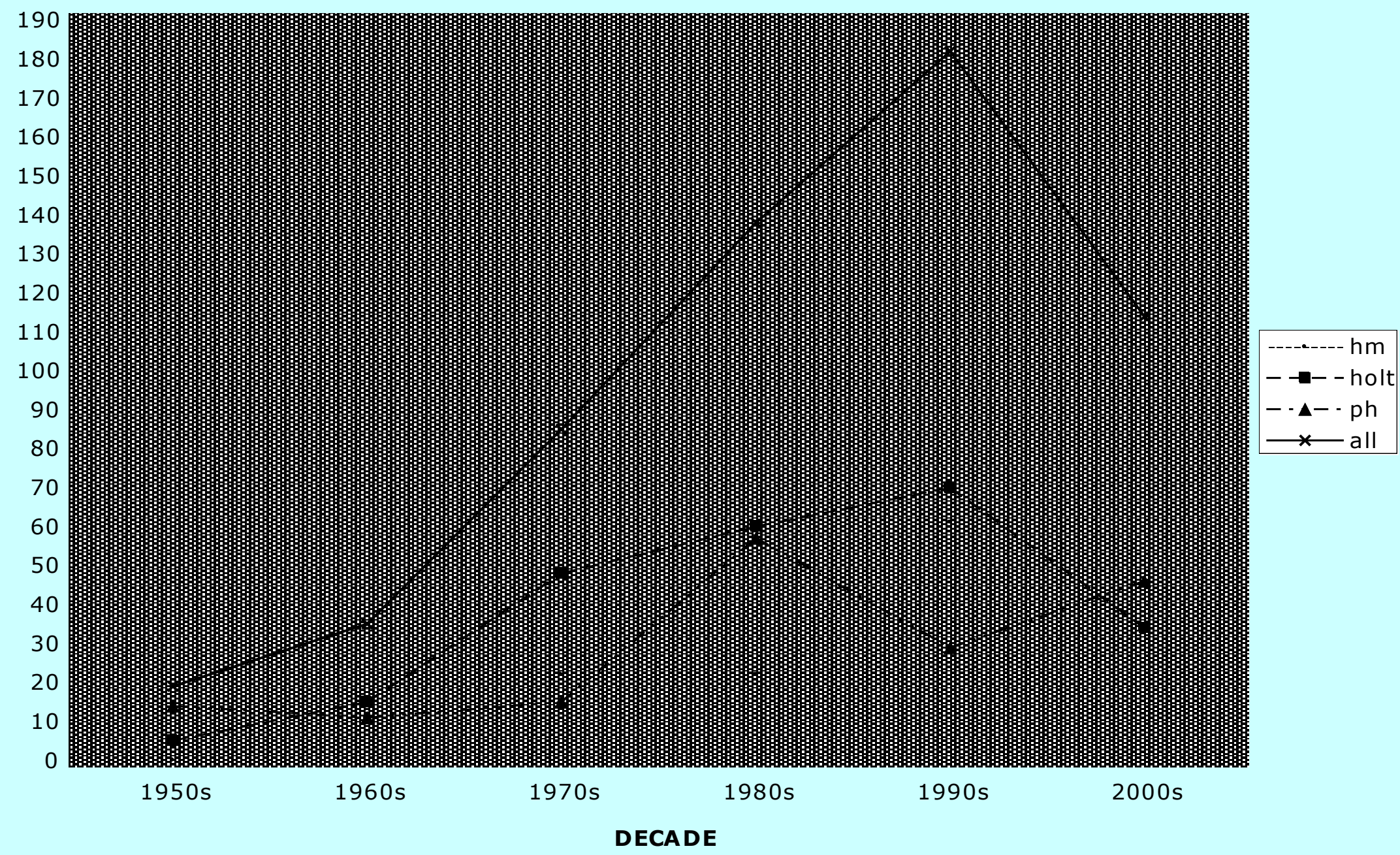




\section{"Jew/Jewish"}

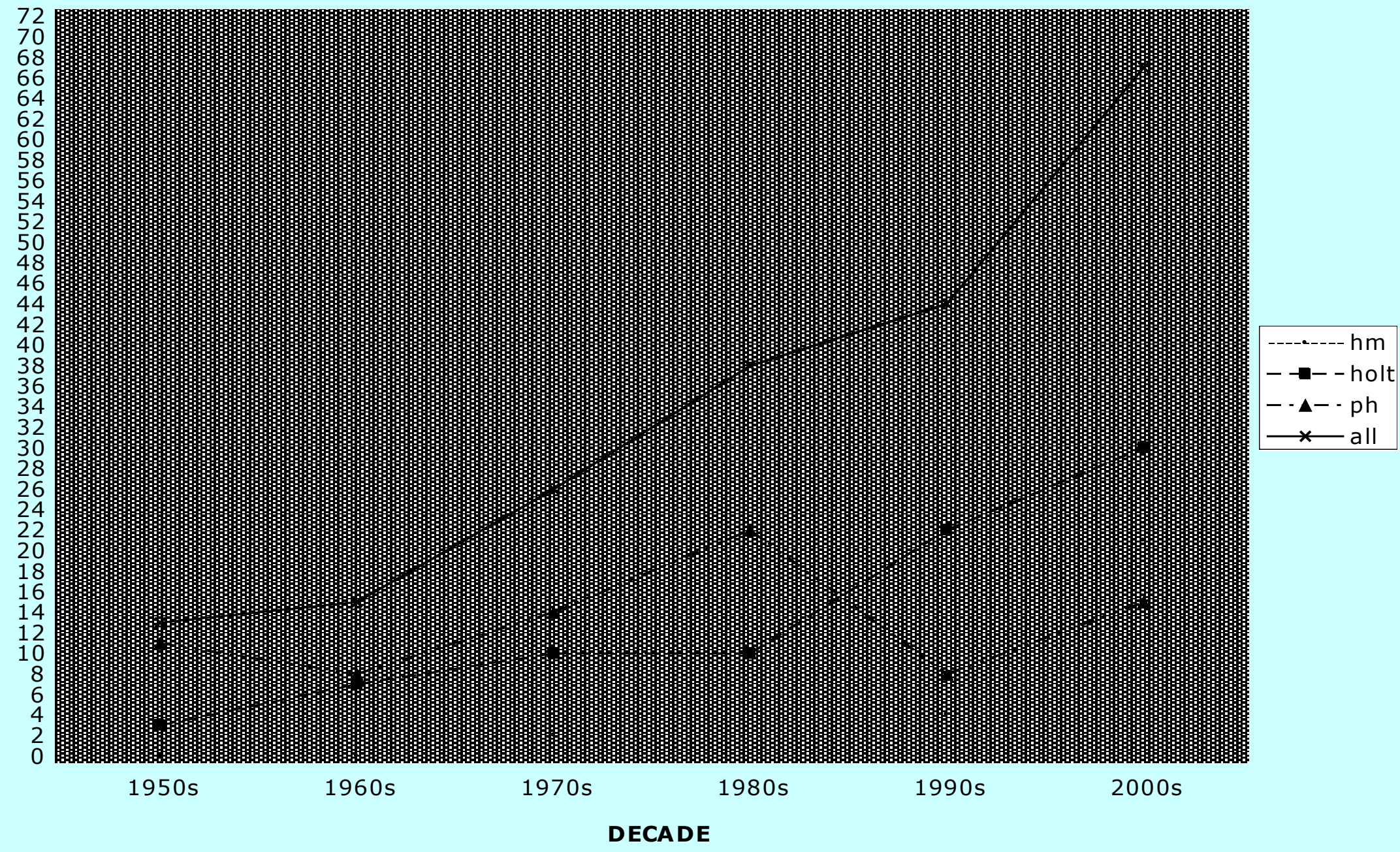




\section{"Palestine"}

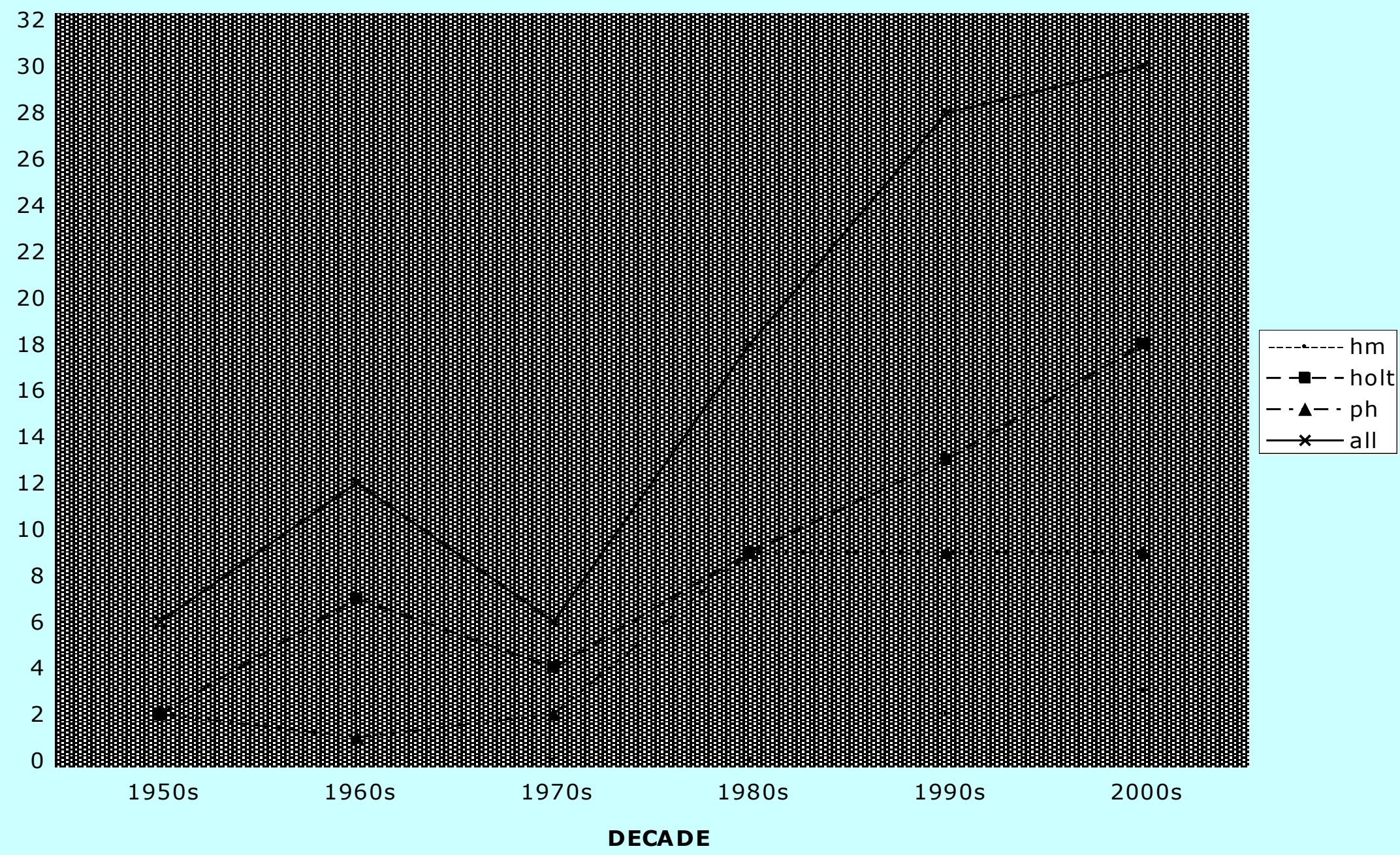


"Palestinian"

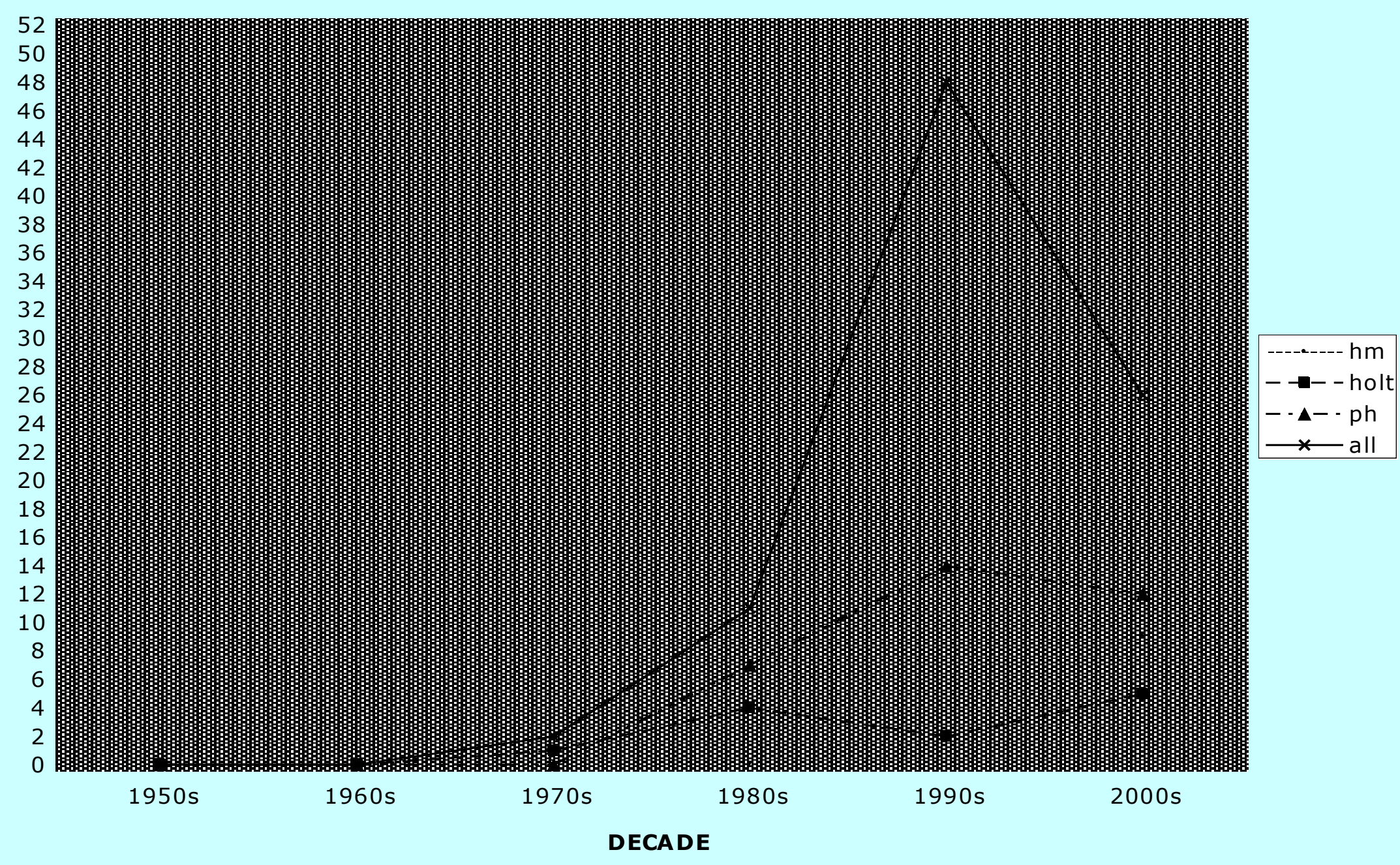


A II Publishers, Terms, and Categories of A nalysis

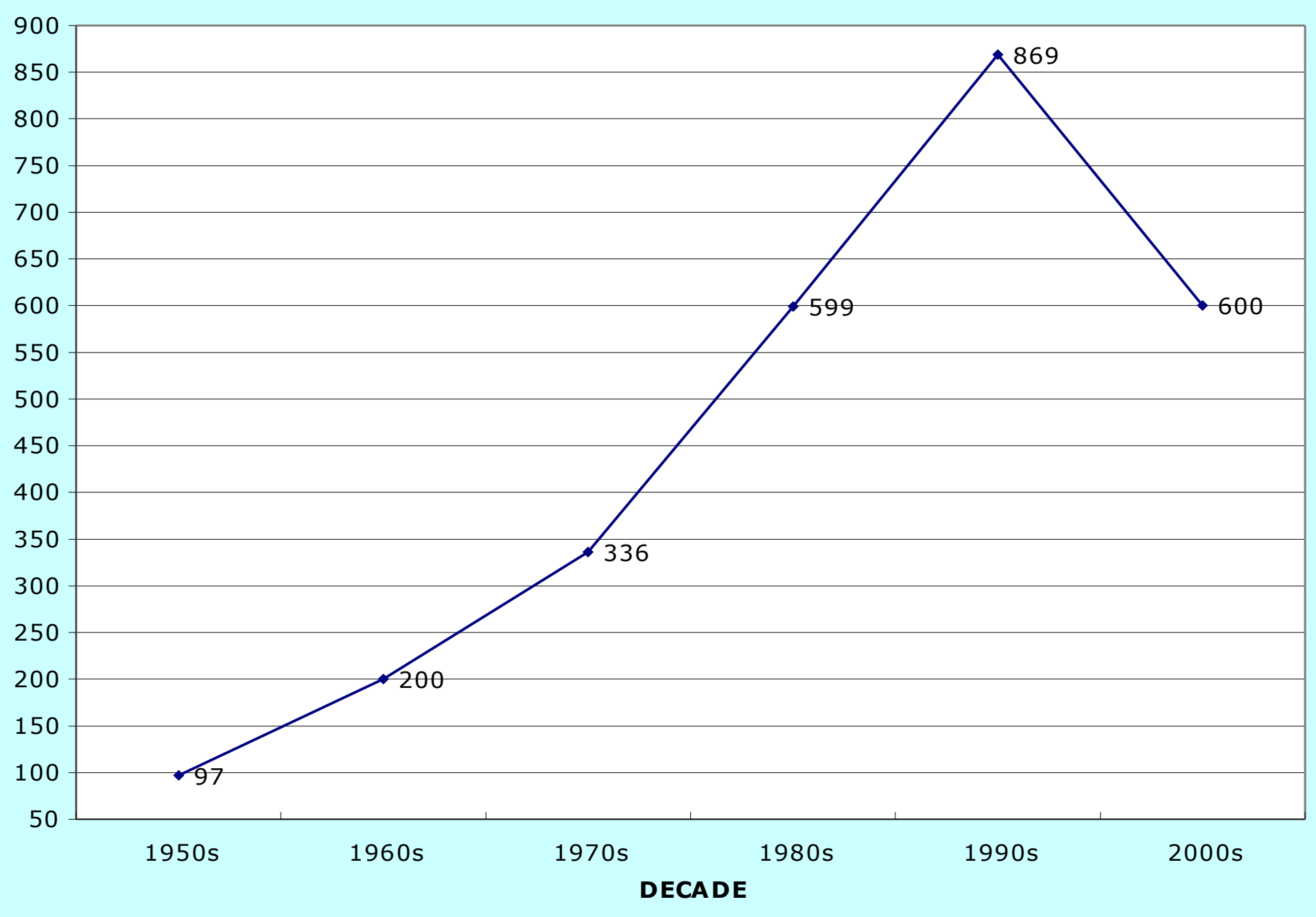


Publisher Ratings on Quality / Amount of Arab-Israeli Information, by Category of Analysis

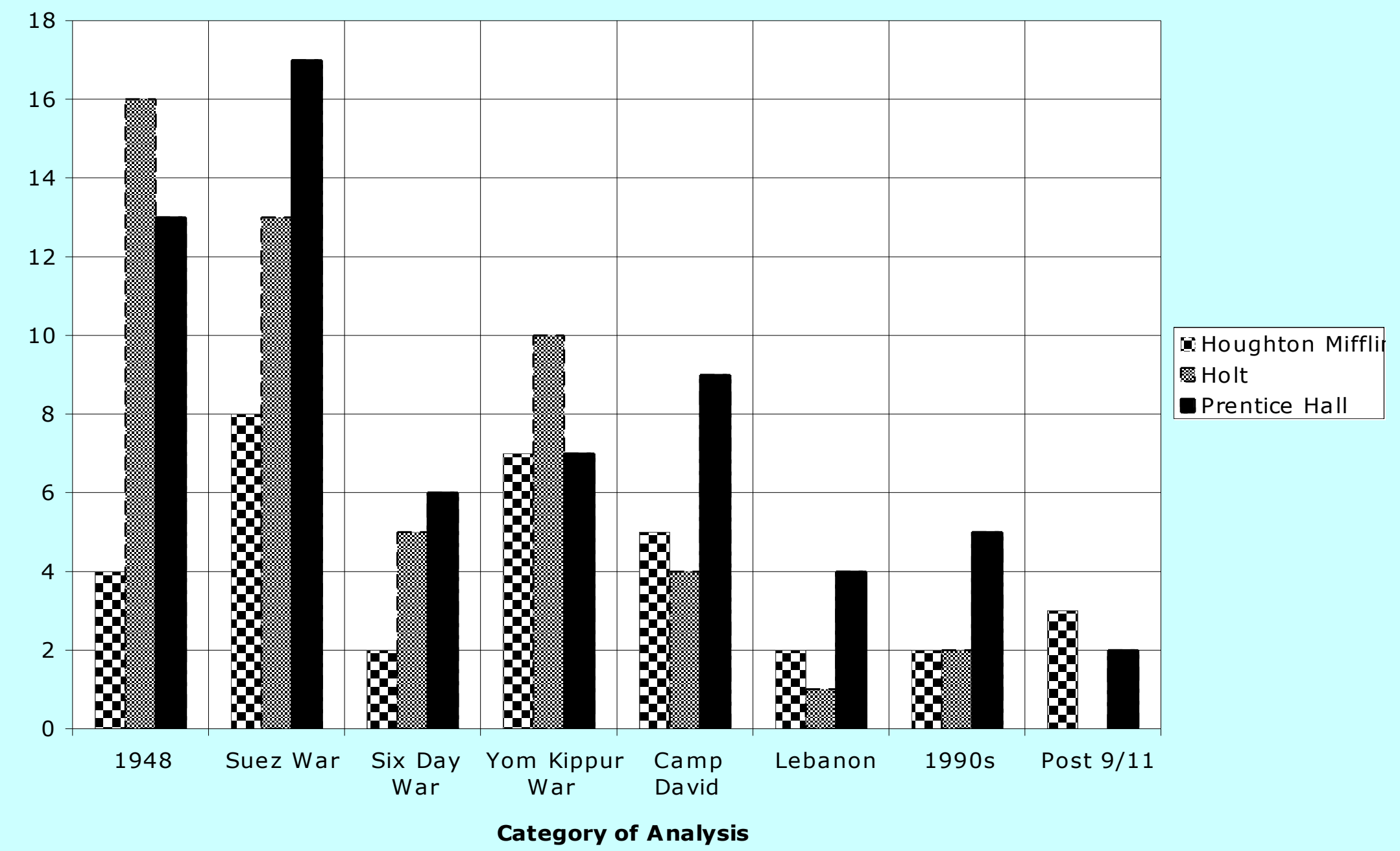


Total Publisher Ratings on Quality / Amount of Arab-Israeli Information For All Categories of Analysis

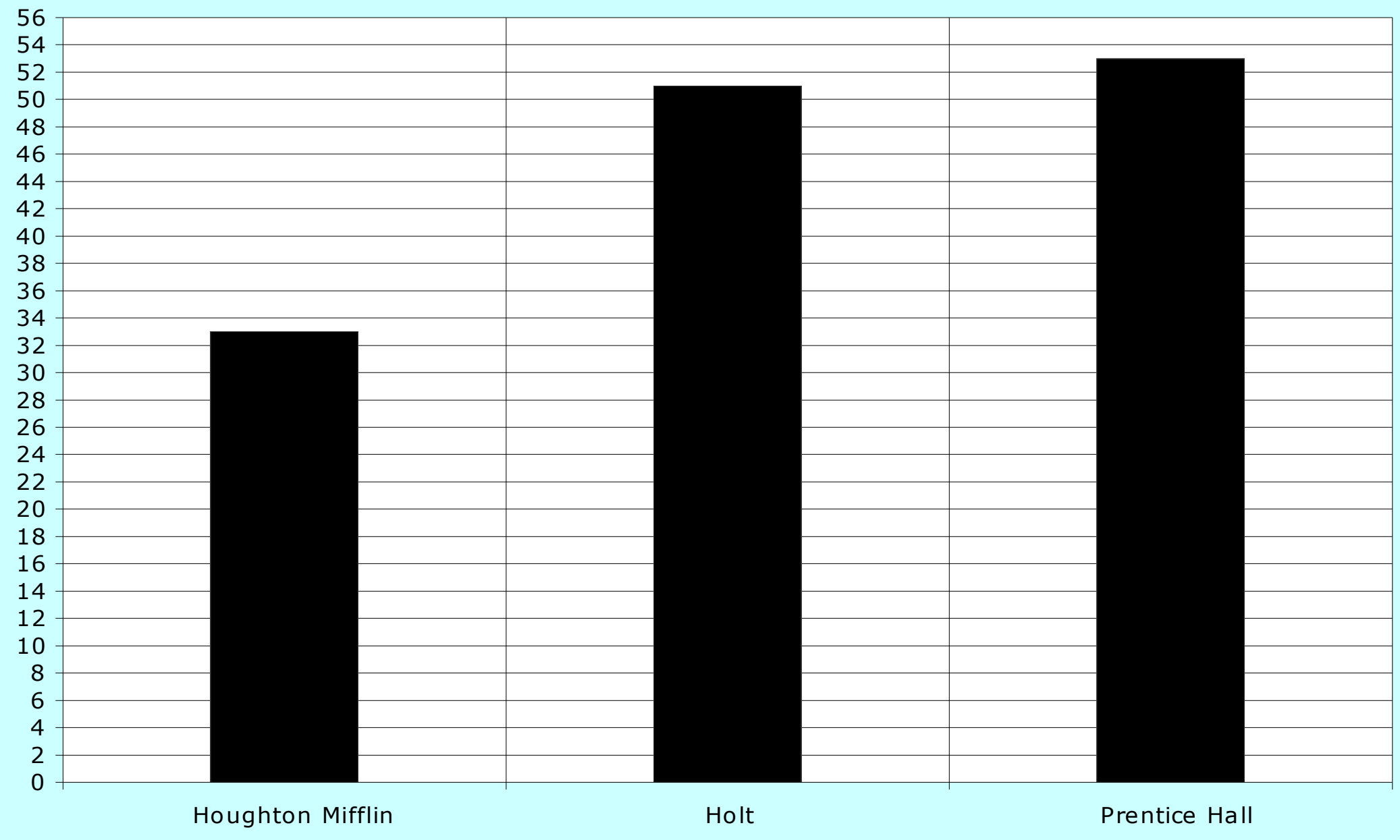




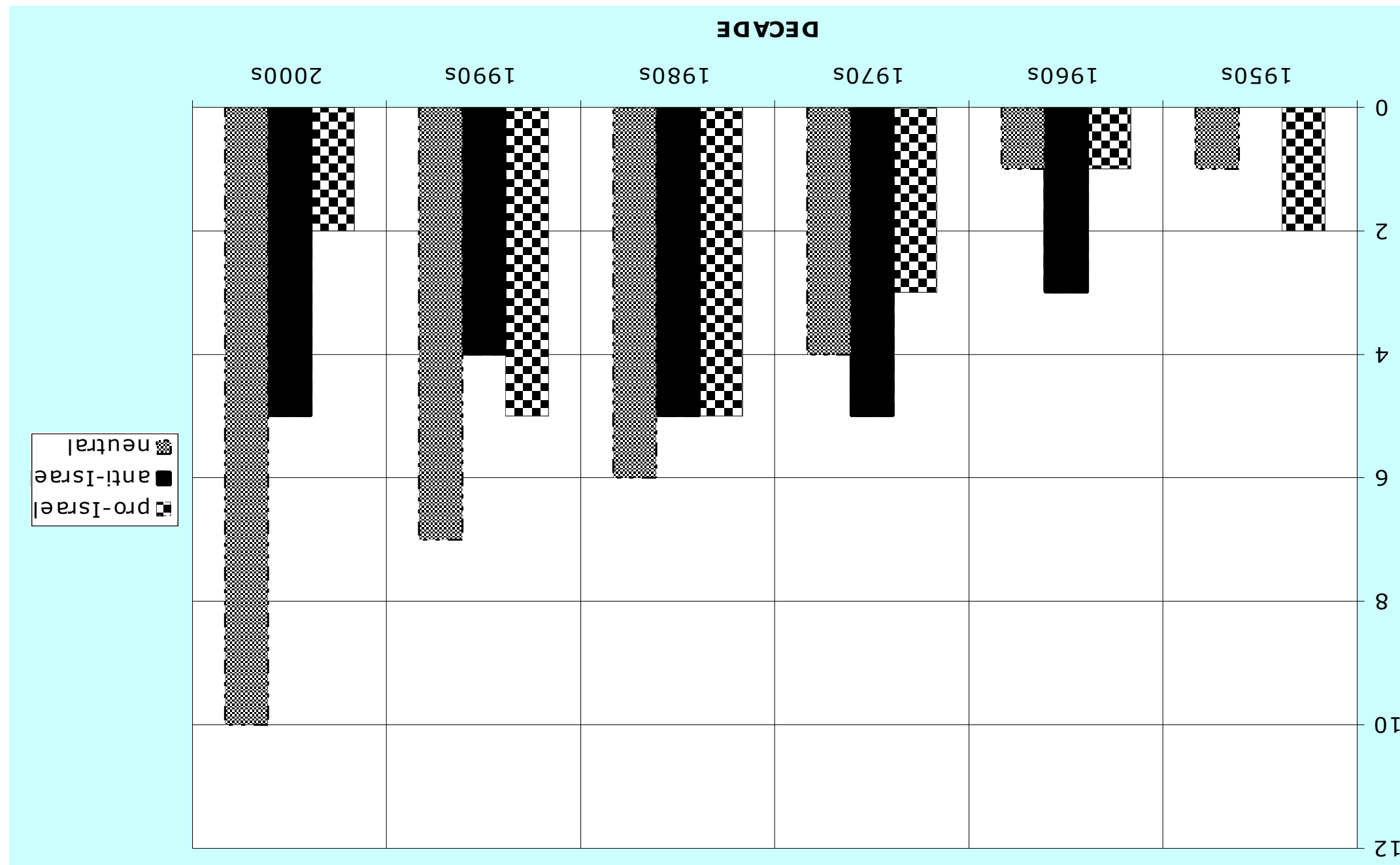

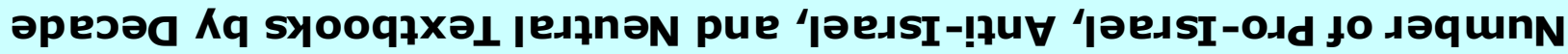


Houghton Mifflin

"HM"

1. 1952: The Making of Modern America (Canfield and Wilder)

4. 1962: The Making of Modern America (Canfield and Wilder)

7. 1975: This is America's Story (Wilder, Ludlum, and Brown)

10. 1986: This is America's Story (Wilder, Ludlum, and Brown)

13. 1996: The Americans: a history (Winthrop, Greenblatt, and Bowes)

16. ****2003: The Americans

(Danzer)
Holt, Rinehart, Winston (Harcourt) "Holt"

2. 1950: America's History (Todd and Curti)

5. 1966: The Rise of the American Nation (Todd and Curti)

8. 1977: The Rise of the American Nation (Todd and Curti)

11. 1986: Triumph of the American Nation (Todd and Curti)

14. 1995: Todd and Curti's the American Nation (Todd and Curti)

17. ****2003: American Nation (Boyer)

\section{Prentice Hall (Pearson)} "PH"

3. 1957: The United States-the History of a Republic (Hofstadter)

6. 1967: The United States-the History of a Republic (Hofstadter)

9. 1976: The United States (Hofstadter)

12. 1986: The American Nation (Davidson)

15. 1995: America: Pathways to the Present (Cayton)

18. ****2005: America: Pathways to the Present (Cayton) 


\begin{tabular}{|c|c|c|c|c|c|c|}
\hline $\begin{array}{l}\text { Topic of } \\
\text { Analysis }\end{array}$ & $\begin{array}{c}\text { 1950s Book } \\
\text { Total }\end{array}$ & $\begin{array}{c}\text { 1960s Book } \\
\text { Total }\end{array}$ & 1970s Book Total & 1980s Book Total & 1990s Book Total & $\begin{array}{c}\text { 2000s Book } \\
\text { Total }\end{array}$ \\
\hline $\begin{array}{l}\text { British } \\
\text { Mandate }\end{array}$ & $\begin{array}{l}\text { Sentences in } \\
\text { main text: } 1 \\
\text { Index pgs.: } 0 \\
\text { Review } \\
\text { Questions: } 0 \\
\text { Picture: } 0\end{array}$ & $\begin{array}{l}\text { Sentences in } \\
\text { main text: } 3 \\
\text { Index pgs.: } 1 \\
\text { Review } \\
\text { Questions: } 0 \\
\text { Picture: } 0\end{array}$ & $\begin{array}{l}\begin{array}{l}\text { Sentences in main } \\
\text { text:3 }\end{array} \\
\text { Index pgs.:0 } \\
\text { Review Questions: } \\
\text { O } \\
\text { Picture:0 }\end{array}$ & $\begin{array}{l}\begin{array}{l}\text { Sentences in main } \\
\text { text:7 }\end{array} \\
\text { Index pgs.:0 } \\
\text { Review Questions: } \\
\text { O } \\
\text { Picture:0 }\end{array}$ & $\begin{array}{l}\begin{array}{l}\text { Sentences in main } \\
\text { text:15 }\end{array} \\
\text { Index pgs.:2 } \\
\text { Review Questions: } \\
1 \\
\text { Picture:2 }\end{array}$ & $\begin{array}{l}\text { Sentences in } \\
\text { main text:10 } \\
\text { Index pgs.:1 } \\
\text { ReviewQuestion } \\
\text { s:2 } \\
\text { Picture:0 }\end{array}$ \\
\hline $\begin{array}{l}\text { Balfour } \\
\text { Declaration } \\
\text { and/or } \\
\text { Establishme } \\
\text { nt of Israel }\end{array}$ & $\begin{array}{l}\text { Sentences in } \\
\text { main text: } 11 \\
\text { Index pgs.: } 1 \\
\text { Review } \\
\text { Questions: } 0 \\
\text { Picture: } 0\end{array}$ & $\begin{array}{l}\begin{array}{l}\text { Sentences in } \\
\text { main text:8 }\end{array} \\
\text { Index pgs.:1 } \\
\text { ReviewQuestion } \\
\text { s:1 } \\
\text { Picture:0 }\end{array}$ & $\begin{array}{l}\begin{array}{l}\text { Sentences in main } \\
\text { text:14 }\end{array} \\
\text { Index pgs.:1 } \\
\text { Review Questions: } \\
2 \\
\text { Picture:0 }\end{array}$ & $\begin{array}{l}\begin{array}{l}\text { Sentences in main } \\
\text { text:22 }\end{array} \\
\text { Index pgs.:0 } \\
\text { Review Questions: } \\
4 \\
\text { Picture:1 }\end{array}$ & $\begin{array}{l}\begin{array}{l}\text { Sentences in main } \\
\text { text:25 }\end{array} \\
\text { Index pgs.:5 } \\
\text { Review Questions: } \\
6 \\
\text { Picture:5 }\end{array}$ & $\begin{array}{l}\begin{array}{l}\text { Sentences in } \\
\text { main text:32 }\end{array} \\
\text { Index pgs.:4 } \\
\text { ReviewQuestion } \\
\text { s:5 } \\
\text { Picture:4 }\end{array}$ \\
\hline $\begin{array}{l}1956 \text { Suez } \\
\text { Canal Crisis }\end{array}$ & $\begin{array}{l}\text { Sentences in } \\
\text { main text:18 } \\
\text { Index pgs.:3 } \\
\text { ReviewQuestion } \\
\text { s:0 } \\
\text { Picture:0 }\end{array}$ & $\begin{array}{l}\begin{array}{l}\text { Sentences in } \\
\text { main text:65 }\end{array} \\
\text { Index pgs.:8 } \\
\text { ReviewQuestion } \\
\text { s:2 } \\
\text { Picture:4 }\end{array}$ & $\begin{array}{l}\begin{array}{l}\text { Sentences in main } \\
\text { text:55 }\end{array} \\
\text { Index pgs.:7 } \\
\text { Review Questions: } \\
4 \\
\text { Picture: } 1\end{array}$ & $\begin{array}{l}\begin{array}{l}\text { Sentences in main } \\
\text { text:33 }\end{array} \\
\text { Index pgs.:7 } \\
\text { Review Questions: } \\
5 \\
\text { Picture:3 }\end{array}$ & $\begin{array}{l}\begin{array}{l}\text { Sentences in main } \\
\text { text:38 }\end{array} \\
\text { Index pgs.:5 } \\
\text { Review Questions: } \\
2 \\
\text { Picture:2 }\end{array}$ & $\begin{array}{l}\text { Sentences in } \\
\text { main text:33 } \\
\text { Index pgs.:3 } \\
\text { ReviewQuestion } \\
\text { s:2 } \\
\text { Picture:1 }\end{array}$ \\
\hline $\begin{array}{l}\text { 1967 Six } \\
\text { Day War }\end{array}$ & & $\begin{array}{l}\text { Sentences in } \\
\text { main text:0 }\end{array}$ & $\begin{array}{l}\text { Sentences in main } \\
\text { text:27 }\end{array}$ & $\begin{array}{l}\text { Sentences in main } \\
\text { text:22 }\end{array}$ & $\begin{array}{l}\text { Sentences in main } \\
\text { text:6 }\end{array}$ & $\begin{array}{l}\text { Sentences in } \\
\text { main text:6 }\end{array}$ \\
\hline
\end{tabular}




\begin{tabular}{|c|c|c|c|c|c|}
\hline & $\begin{array}{l}\text { Index pgs.:0 } \\
\text { ReviewQuestion } \\
\text { s:0 } \\
\text { Picture:0 }\end{array}$ & $\begin{array}{l}\text { Index pgs.:1 } \\
\text { Review Questions: } \\
1 \\
\text { Picture:0 }\end{array}$ & $\begin{array}{l}\text { Index pgs.:1 } \\
\text { Review Questions: } \\
1 \\
\text { Picture:2 }\end{array}$ & $\begin{array}{l}\text { Index pgs.:1 } \\
\text { Review Questions: } \\
\text { 0 } \\
\text { Picture:4 }\end{array}$ & $\begin{array}{l}\text { Index pgs.:2 } \\
\text { ReviewQuestion } \\
\text { s:0 } \\
\text { Picture:0 }\end{array}$ \\
\hline $\begin{array}{l}1973 \text { Yom } \\
\text { Kippur War }\end{array}$ & & $\begin{array}{l}\begin{array}{l}\text { Sentences in main } \\
\text { text:35 }\end{array} \\
\text { Index pgs.:0 } \\
\text { Review Questions: } \\
2 \\
\text { Picture:1 }\end{array}$ & $\begin{array}{l}\begin{array}{l}\text { Sentences in main } \\
\text { text:54 }\end{array} \\
\text { Index pgs.:6 } \\
\text { Review Questions: } \\
4 \\
\text { Picture:1 }\end{array}$ & $\begin{array}{l}\text { Sentences in main } \\
\text { text:27 } \\
\text { Index pgs.:4 } \\
\text { Review Questions: } \\
4 \\
\text { Picture:3 }\end{array}$ & $\begin{array}{l}\begin{array}{l}\text { Sentences in } \\
\text { main text:30 }\end{array} \\
\text { Index pgs.:1 } \\
\text { ReviewQuestion } \\
\text { s:0 } \\
\text { Picture:3 }\end{array}$ \\
\hline $\begin{array}{l}\text { 1979 Camp } \\
\text { David } \\
\text { Accords }\end{array}$ & & & $\begin{array}{l}\text { Sentences in main } \\
\text { text:40 } \\
\text { Index pgs.:2 } \\
\text { Review } \\
\text { Questions:4 } \\
\text { Picture:5 }\end{array}$ & $\begin{array}{l}\text { Sentences in main } \\
\text { text:67 } \\
\text { Index pgs.:8 } \\
\text { ReviewQuestions: } \\
11 \\
\text { Picture:6 }\end{array}$ & $\begin{array}{l}\text { Sentences in } \\
\text { main text:37 } \\
\text { Index pgs.:4 } \\
\text { ReviewQuestion } \\
\text { s:13 } \\
\text { Picture:6 }\end{array}$ \\
\hline $\begin{array}{l}1980 \text { 's } \\
\text { conflict in } \\
\text { Lebanon }\end{array}$ & & & $\begin{array}{l}\text { Sentences in main } \\
\text { text:46 } \\
\text { Index pgs.:6 } \\
\text { Review Questions: } \\
2\end{array}$ & $\begin{array}{l}\begin{array}{l}\text { Sentences in main } \\
\text { text:17 }\end{array} \\
\text { Index pgs.:5 } \\
\text { Review Questions: } \\
0\end{array}$ & $\begin{array}{l}\text { Sentences in } \\
\text { main text:8 } \\
\text { Index pgs.:1 } \\
\text { ReviewQuestion } \\
\text { s:0 }\end{array}$ \\
\hline
\end{tabular}




\begin{tabular}{|c|c|c|c|c|c|c|}
\hline & & & & Picture:2 & Picture:1 & Picture:1 \\
\hline $\begin{array}{l}\text { 1991-1994 } \\
\text { peace talks }\end{array}$ & & & & & $\begin{array}{l}\text { Sentences in main } \\
\text { text:49 } \\
\text { Index pgs.:0 } \\
\text { Review Questions: } \\
5 \\
\text { Picture:6 }\end{array}$ & $\begin{array}{l}\begin{array}{l}\text { Sentences in } \\
\text { main text:22 }\end{array} \\
\text { Index pgs.:0 } \\
\text { ReviewQuestion } \\
\text { s:3 } \\
\text { Picture:1 }\end{array}$ \\
\hline $\begin{array}{l}\text { Post 9/11 } \\
\text { Arab-Israeli } \\
\text { conflict }\end{array}$ & & & & & & $\begin{array}{l}\text { Sentences in } \\
\text { main text:8 } \\
\text { Index pgs.:0 } \\
\text { ReviewQuestion } \\
\text { s:1 } \\
\text { Picture:0 }\end{array}$ \\
\hline $\begin{array}{l}\text { David Ben- } \\
\text { Gurion }\end{array}$ & $\begin{array}{l}\text { Sentences in } \\
\text { main text:1 } \\
\text { Index pgs.:0 } \\
\text { ReviewQuestion } \\
\text { s:0 } \\
\text { Picture:1 }\end{array}$ & $\begin{array}{l}\begin{array}{l}\text { Sentences in } \\
\text { main text:0 }\end{array} \\
\text { Index pgs.:0 } \\
\text { ReviewQuestion } \\
\text { s:0 } \\
\text { Picture:0 }\end{array}$ & $\begin{array}{l}\text { Sentences in main } \\
\text { text:0 } \\
\text { Index pgs.:0 } \\
\text { Review Questions: } \\
\text { o } \\
\text { Picture:0 }\end{array}$ & $\begin{array}{l}\text { Sentences in main } \\
\text { text:0 } \\
\text { Index pgs.:0 } \\
\text { Review Questions: } \\
0 \\
\quad \text { Picture:0 }\end{array}$ & $\begin{array}{l}\begin{array}{l}\text { Sentences in main } \\
\text { text:9 }\end{array} \\
\text { Index pgs.:3 } \\
\text { Review Questions: } \\
2 \\
\text { Picture:1 }\end{array}$ & $\begin{array}{l}\begin{array}{l}\text { Sentences in } \\
\text { main text:5 }\end{array} \\
\text { Index pgs.:2 } \\
\text { ReviewQuestion } \\
\text { s:1 } \\
\text { Picture:0 }\end{array}$ \\
\hline Golda Meir & & & & & $\begin{array}{l}\text { Sentences in main } \\
\text { text:4 }\end{array}$ & $\begin{array}{l}\text { Sentences in } \\
\text { main text:1 }\end{array}$ \\
\hline
\end{tabular}




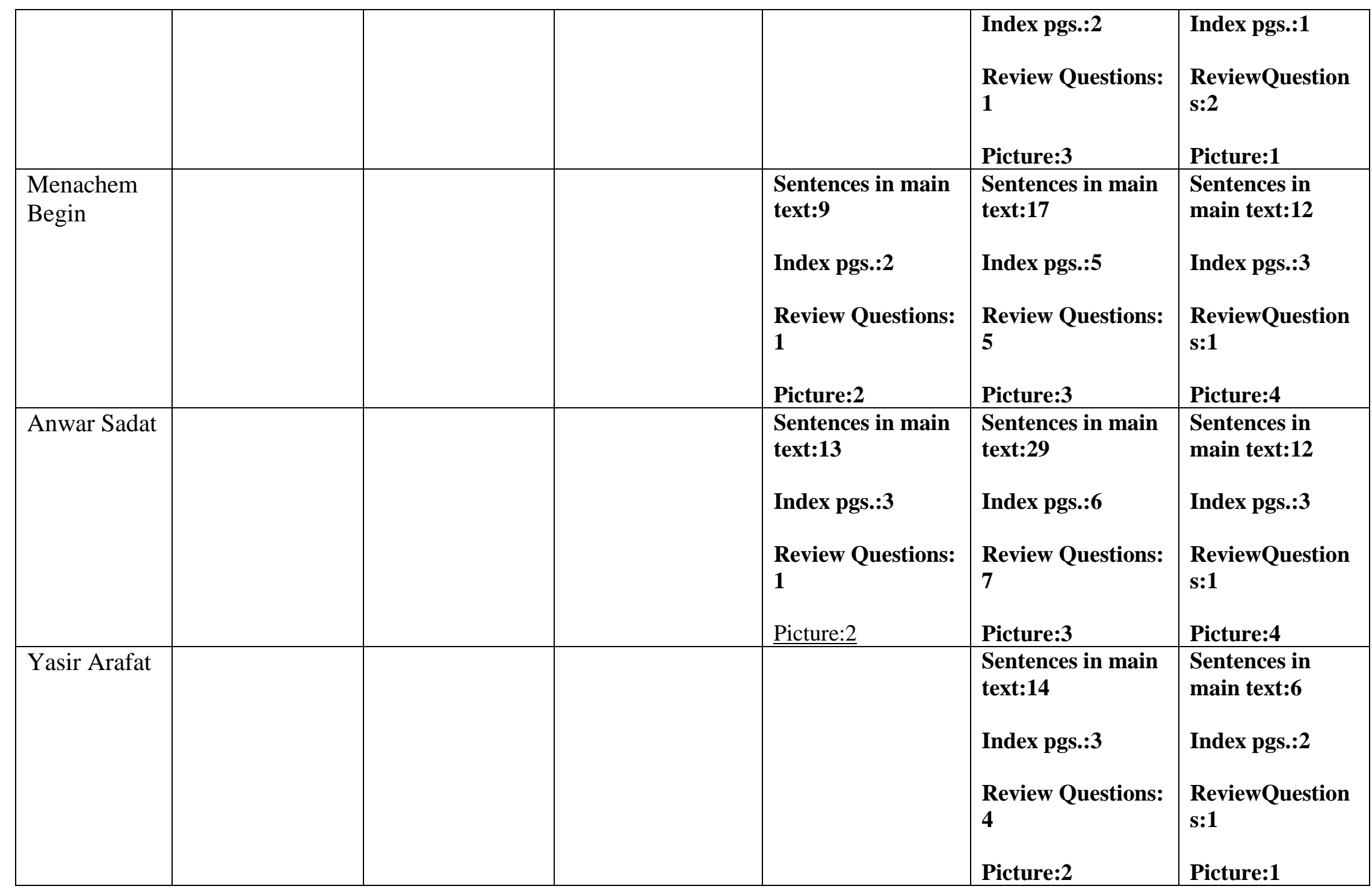




\begin{tabular}{|c|c|c|c|c|c|c|}
\hline $\begin{array}{l}\text { Gamal } \\
\text { Abdal } \\
\text { Nasser }\end{array}$ & $\begin{array}{l}\text { Sentences in } \\
\text { main text:2 } \\
\text { Index pgs.:1 } \\
\text { ReviewQuestion } \\
\text { s:0 } \\
\text { Picture:0 }\end{array}$ & $\begin{array}{l}\text { Sentences in } \\
\text { main text:16 } \\
\text { Index pgs.: } 7 \\
\text { ReviewQuestion } \\
\text { s:1 } \\
\text { Picture:0 }\end{array}$ & $\begin{array}{l}\text { Sentences in main } \\
\text { text:9 } \\
\text { Index pgs.:4 } \\
\text { Review Questions: } \\
1 \\
\text { Picture:0 }\end{array}$ & $\begin{array}{l}\text { Sentences in main } \\
\text { text:6 } \\
\text { Index pgs.: } 1 \\
\text { Review Questions: } \\
1 \\
\text { Picture:0 }\end{array}$ & $\begin{array}{l}\text { Sentences in main } \\
\text { text:7 } \\
\text { Index pgs.:2 } \\
\text { Review Questions: } \\
1 \\
\text { Picture:0 }\end{array}$ & $\begin{array}{l}\text { Sentences in } \\
\text { main text:6 } \\
\text { Index pgs.:3 } \\
\text { ReviewQuestion } \\
\text { s:0 } \\
\text { Picture:0 }\end{array}$ \\
\hline $\begin{array}{l}\text { Yitzhak } \\
\text { Rabin }\end{array}$ & & & & & $\begin{array}{l}\begin{array}{l}\text { Sentences in main } \\
\text { text:13 }\end{array} \\
\text { Index pgs.:3 } \\
\text { Review Questions: } \\
4 \\
\text { Picture:3 }\end{array}$ & $\begin{array}{l}\text { Sentences in } \\
\text { main text:6 } \\
\text { Index pgs.:2 } \\
\text { ReviewQuestion } \\
\text { s:1 } \\
\text { Picture:2 }\end{array}$ \\
\hline $\begin{array}{l}\text { Term: } \\
\text { "Arab (s)" }\end{array}$ & $\begin{array}{l}\text { Sentences in } \\
\text { main text:17 } \\
\text { Index pgs.:3 } \\
\text { ReviewQuestion } \\
\text { s:0 } \\
\text { Picture:0 }\end{array}$ & $\begin{array}{l}\text { Sentences in } \\
\text { main text:17 } \\
\text { Index pgs.:0 } \\
\text { ReviewQuestion } \\
\text { s:0 } \\
\text { Picture:0 }\end{array}$ & $\begin{array}{l}\begin{array}{l}\text { Sentences in main } \\
\text { text:33 }\end{array} \\
\text { Index pgs.:13 } \\
\text { Review Questions: } \\
1 \\
\text { Picture:0 }\end{array}$ & $\begin{array}{l}\begin{array}{l}\text { Sentences in main } \\
\text { text:55 }\end{array} \\
\text { Index pgs.:16 } \\
\text { Review Questions: } \\
1 \\
\text { Picture:1 }\end{array}$ & $\begin{array}{l}\begin{array}{l}\text { Sentences in main } \\
\text { text:76 }\end{array} \\
\text { Index pgs.:1 } \\
\text { Review Questions: } \\
1 \\
\text { Picture:1 }\end{array}$ & $\begin{array}{l}\text { Sentences in } \\
\text { main text:34 } \\
\text { Index pgs.:0 } \\
\text { ReviewQuestion } \\
\text { s:3 } \\
\text { Picture:0 }\end{array}$ \\
\hline $\begin{array}{l}\text { Term: } \\
\text { "Israel", }\end{array}$ & $\begin{array}{l}\text { Sentences in } \\
\text { main text:15 }\end{array}$ & $\begin{array}{l}\text { Sentences in } \\
\text { main text: } 27\end{array}$ & $\begin{array}{l}\text { Sentences in main } \\
\text { text:65 }\end{array}$ & $\begin{array}{l}\text { Sentences in main } \\
\text { text:111 }\end{array}$ & $\begin{array}{l}\text { Sentences in main } \\
\text { text:151 }\end{array}$ & $\begin{array}{l}\text { Sentences in } \\
\text { main text:97 }\end{array}$ \\
\hline
\end{tabular}




\begin{tabular}{|c|c|c|c|c|c|c|}
\hline $\begin{array}{l}\text { and/or } \\
\text { "Israeli", }\end{array}$ & $\begin{array}{l}\text { Review } \\
\text { Questions: } \\
1 \\
\text { Picture:0 }\end{array}$ & $\begin{array}{l}\text { Review } \\
\text { Questions: } \\
\text { 0 } \\
\text { Picture:2 }\end{array}$ & $\begin{array}{l}\text { Review Questions: } \\
2 \\
\text { Picture:0 }\end{array}$ & $\begin{array}{l}\text { Review Questions: } \\
6 \\
\text { Picture:2 }\end{array}$ & $\begin{array}{l}\text { Review Questions: } \\
7 \\
\text { Picture:3 }\end{array}$ & $\begin{array}{l}\text { ReviewQuestion } \\
\text { s:1 } \\
\text { Picture:2 }\end{array}$ \\
\hline $\begin{array}{l}\text { Term: } \\
\text { "Jews" } \\
\text { and/or } \\
\text { "Jewish" }\end{array}$ & $\begin{array}{l}\text { Sentences in } \\
\text { main text:4 } \\
\text { Index pgs.:9 } \\
\text { ReviewQuestion } \\
\text { s:0 } \\
\text { Picture:0 }\end{array}$ & $\begin{array}{l}\text { Sentences in } \\
\text { main text:3 } \\
\text { Index pgs.:12 } \\
\text { ReviewQuestion } \\
\text { s:0 } \\
\text { Picture:0 }\end{array}$ & $\begin{array}{l}\text { Sentences in main } \\
\text { text:7 } \\
\text { Index pgs.: } 19 \\
\text { Review Questions: } \\
\text { 0 } \\
\text { Picture:0 }\end{array}$ & $\begin{array}{l}\text { Sentences in main } \\
\text { text:13 } \\
\text { Index pgs.:25 } \\
\text { Review Questions: } \\
0 \\
\text { Picture:0 }\end{array}$ & $\begin{array}{l}\text { Sentences in main } \\
\text { text:23 } \\
\text { Index pgs.:21 } \\
\text { Review Questions: } \\
0 \\
\text { Picture:0 }\end{array}$ & $\begin{array}{l}\begin{array}{l}\text { Sentences in } \\
\text { main text:38 }\end{array} \\
\text { Index pgs.:27 } \\
\text { ReviewQuestion } \\
\text { s:2 } \\
\text { Picture:0 }\end{array}$ \\
\hline $\begin{array}{l}\text { Term: } \\
\text { "Palestine" }\end{array}$ & $\begin{array}{l}\text { Sentences in } \\
\text { main text:4 } \\
\text { Index pgs.:1 } \\
\text { ReviewQuestion } \\
\text { s:0 } \\
\text { Picture:1 }\end{array}$ & $\begin{array}{l}\text { Sentences in } \\
\text { main text:4 } \\
\text { Index pgs.:6 } \\
\text { ReviewQuestion } \\
\text { s:0 } \\
\text { Picture:2 }\end{array}$ & $\begin{array}{l}\begin{array}{l}\text { Sentences in main } \\
\text { text:3 }\end{array} \\
\text { Index pgs.:3 } \\
\text { Review Questions: } \\
0 \\
\text { Picture:0 }\end{array}$ & $\begin{array}{l}\begin{array}{l}\text { Sentences in main } \\
\text { text:14 }\end{array} \\
\text { Index pgs.:2 } \\
\text { Review Questions: } \\
1 \\
\text { Picture:1 }\end{array}$ & $\begin{array}{l}\begin{array}{l}\text { Sentences in main } \\
\text { text:27 }\end{array} \\
\text { Index pgs::0 } \\
\text { Review Questions: } \\
1 \\
\text { Picture:0 }\end{array}$ & $\begin{array}{l}\text { Sentences in } \\
\text { main text:24 } \\
\text { Index pgs.:4 } \\
\text { ReviewQuestion } \\
\text { s:2 } \\
\text { Picture:0 }\end{array}$ \\
\hline $\begin{array}{l}\text { Term: } \\
\text { "Palestinian" }\end{array}$ & $\begin{array}{l}\text { Sentences in } \\
\text { main text:0 } \\
\text { Index pgs.:0 } \\
\text { ReviewQuestion } \\
\text { s:0 }\end{array}$ & $\begin{array}{l}\text { Sentences in } \\
\text { main text:0 } \\
\text { Index pgs.:0 } \\
\text { ReviewQuestion } \\
\text { s:0 }\end{array}$ & $\begin{array}{l}\begin{array}{l}\text { Sentences in main } \\
\text { text:2 }\end{array} \\
\text { Index pgs.:0 } \\
\text { Review Questions: } \\
\text { 0 }\end{array}$ & $\begin{array}{l}\text { Sentences in main } \\
\text { text:8 } \\
\text { Index pgs.:2 } \\
\text { Review Questions: } \\
1\end{array}$ & $\begin{array}{l}\begin{array}{l}\text { Sentences in main } \\
\text { text:45 }\end{array} \\
\text { Index pgs.:1 } \\
\text { Review Questions: } \\
1\end{array}$ & $\begin{array}{l}\begin{array}{l}\text { Sentences in } \\
\text { main text:19 }\end{array} \\
\text { Index pgs.:5 } \\
\text { ReviewQuestion } \\
\text { s:1 }\end{array}$ \\
\hline
\end{tabular}




\begin{tabular}{|l|l|l|l|l|l|l|}
\hline & Picture:0 & Picture:0 & Picture:0 & Picture:0 & Picture:1 & Picture:1 \\
\hline
\end{tabular}

\begin{tabular}{|c|c|c|c|c|c|c|c|c|}
\hline $\begin{array}{l}\text { Topic of } \\
\text { Analysis }\end{array}$ & $\begin{array}{c}\text { Book 1 } \\
\text { HM } 1952 \\
\end{array}$ & $\begin{array}{c}\text { Book 2 } \\
\text { Holt } 1950 \\
\end{array}$ & $\begin{array}{c}\text { Book 3 } \\
\text { PH 1957 } \\
\end{array}$ & $\begin{array}{c}\text { 1950s Books } \\
\text { Total } \\
\end{array}$ & $\begin{array}{c}\text { Book } 4 \\
\text { HM } 1962 \\
\end{array}$ & $\begin{array}{c}\text { Book 5 } \\
\text { Holt } 1966 \\
\end{array}$ & $\begin{array}{c}\text { Book } 6 \\
\text { PH } 1967 \\
\end{array}$ & $\begin{array}{c}\text { 1960s Book } \\
\text { Total }\end{array}$ \\
\hline $\begin{array}{l}\text { British } \\
\text { Mandate }\end{array}$ & $\begin{array}{l}\text { Sentences in } \\
\text { main text: } 0 \\
\text { Index pgs.: } 0 \\
\text { Review } \\
\text { Questions: } 0 \\
\text { Picture: } 0\end{array}$ & $\begin{array}{l}\text { Sentences in } \\
\text { main text: } 0 \\
\text { Index pgs.: } 0 \\
\text { Review } \\
\text { Questions: } 0 \\
\text { Picture: } 0\end{array}$ & $\begin{array}{l}\text { Sentences in } \\
\text { main text: } 1 \\
\text { Index pgs.: } 0 \\
\text { Review } \\
\text { Questions: } 0 \\
\text { Picture: } 0\end{array}$ & $\begin{array}{l}\text { Sentences in } \\
\text { main text: } 1 \\
\text { Index pgs.: } 0 \\
\text { Review } \\
\text { Questions: } \\
0 \\
\text { Picture: } 0\end{array}$ & $\begin{array}{l}\text { Sentences in } \\
\text { main text: } 0 \\
\text { Index pgs.: } 0 \\
\text { Review } \\
\text { Questions: } 0 \\
\text { Picture: } 0\end{array}$ & $\begin{array}{l}\text { Sentences in } \\
\text { main text: } 1 \\
\text { Index pgs.: } 1 \\
\text { Review } \\
\text { Questions: } 0 \\
\text { Picture: } 0\end{array}$ & $\begin{array}{l}\text { Sentences in } \\
\text { main text: } 2 \\
\text { Index pgs.: } 0 \\
\text { Review } \\
\text { Questions: } 0 \\
\text { Picture: } 0\end{array}$ & $\begin{array}{l}\text { Sentences in } \\
\text { main text: } 3 \\
\text { Index pgs.: } 1 \\
\text { Review } \\
\text { Questions: } 0 \\
\text { Picture: } 0\end{array}$ \\
\hline $\begin{array}{l}\text { Balfour } \\
\text { Declaration } \\
\text { and/or } \\
\text { Establishment } \\
\text { of Israel }\end{array}$ & $\begin{array}{l}\text { Sentences in } \\
\text { main text: } 0 \\
\text { Index pgs.: } 0 \\
\text { Review } \\
\text { Questions: } 0 \\
\text { Picture: } 0\end{array}$ & $\begin{array}{l}\text { Sentences in } \\
\text { main text: } 2 \\
\text { Index pgs.: } 0 \\
\text { Review } \\
\text { Questions: } 0 \\
\text { Picture: } 0\end{array}$ & $\begin{array}{l}\text { Sentences in } \\
\text { main text: } 9 \\
\text { Index pgs.: } 1 \\
\text { Review } \\
\text { Questions: } 0 \\
\text { Picture: } 0\end{array}$ & $\begin{array}{l}\text { Sentences in } \\
\text { main text: } \\
11 \\
\text { Index pgs.: } 1 \\
\text { Review } \\
\text { Questions: } 0 \\
\text { Picture: } 0\end{array}$ & $\begin{array}{l}\text { Sentences in } \\
\text { main text: } 1 \\
\text { Index pgs.: } 0 \\
\text { Review } \\
\text { Questions: } 0 \\
\text { Picture: } 0\end{array}$ & $\begin{array}{l}\text { Sentences in } \\
\text { main text: } 5 \\
\text { Index pgs.: } 1 \\
\text { Review } \\
\text { Questions: } 1 \\
\text { Picture: } 0\end{array}$ & $\begin{array}{l}\text { Sentences in } \\
\text { main text: } 2 \\
\text { Index pgs.:0 } \\
\text { Review } \\
\text { Questions:0 } \\
\text { Picture:0 }\end{array}$ & $\begin{array}{l}\text { Sentences in } \\
\text { main text:8 } \\
\text { Index pgs.:1 } \\
\text { Review } \\
\text { Questions:1 } \\
\text { Picture:0 }\end{array}$ \\
\hline $\begin{array}{l}1956 \text { Suez } \\
\text { Canal Crisis }\end{array}$ & & & $\begin{array}{l}\text { Sentences in } \\
\text { main text:18 } \\
\text { Index pgs.:3 }\end{array}$ & $\begin{array}{l}\text { Sentences in } \\
\text { main text:18 } \\
\text { Index pgs.:3 }\end{array}$ & $\begin{array}{l}\text { Sentences in } \\
\text { main text:25 } \\
\text { Index pgs.:1 }\end{array}$ & $\begin{array}{l}\text { Sentences in } \\
\text { main text:29 } \\
\text { Index pgs.:7 }\end{array}$ & $\begin{array}{l}\text { Sentences in } \\
\text { main text:11 } \\
\text { Index pgs.:0 }\end{array}$ & $\begin{array}{l}\text { Sentences in } \\
\text { main text:65 } \\
\text { Index pgs.:8 } \\
\end{array}$ \\
\hline
\end{tabular}




\begin{tabular}{|c|c|c|c|c|c|c|c|c|}
\hline & & & $\begin{array}{l}\text { Review } \\
\text { Questions:0 } \\
\text { Picture:0 }\end{array}$ & $\begin{array}{l}\text { Review } \\
\text { Questions:0 } \\
\text { Picture:0 }\end{array}$ & $\begin{array}{l}\text { Review } \\
\text { Questions:0 } \\
\text { Picture:0 }\end{array}$ & $\begin{array}{l}\text { Review } \\
\text { Questions:2 } \\
\text { Picture:4 }\end{array}$ & $\begin{array}{l}\text { Review } \\
\text { Questions:0 } \\
\text { Picture:0 }\end{array}$ & $\begin{array}{l}\text { Review } \\
\text { Questions:2 } \\
\text { Picture:4 }\end{array}$ \\
\hline $\begin{array}{l}1967 \text { Six Day } \\
\text { War }\end{array}$ & & & & & & & $\begin{array}{l}\text { Sentences in } \\
\text { main text:0 } \\
\text { Index pgs.:0 } \\
\text { Review } \\
\text { Questions:0 } \\
\text { Picture:0 }\end{array}$ & $\begin{array}{l}\begin{array}{l}\text { Sentences in } \\
\text { main text:0 }\end{array} \\
\text { Index pgs.:0 } \\
\text { Review } \\
\text { Questions:0 } \\
\text { Picture:0 }\end{array}$ \\
\hline $\begin{array}{l}\text { David Ben- } \\
\text { Gurion }\end{array}$ & $\begin{array}{l}\text { Sentences in } \\
\text { main text: } 0 \\
\text { Index pgs.:0 } \\
\text { Review } \\
\text { Questions:0 } \\
\text { Picture: } 0\end{array}$ & $\begin{array}{l}\text { Sentences in } \\
\text { main text: } 1 \\
\text { Index pgs.:0 } \\
\text { Review } \\
\text { Questions:0 } \\
\text { Picture: } 1\end{array}$ & $\begin{array}{l}\text { Sentences in } \\
\text { main text:0 } \\
\text { Index pgs.:0 } \\
\text { Review } \\
\text { Questions:0 } \\
\text { Picture:0 }\end{array}$ & $\begin{array}{l}\text { Sentences in } \\
\text { main text:1 } \\
\text { Index pgs.:0 } \\
\text { Review } \\
\text { Questions:0 } \\
\text { Picture:1 }\end{array}$ & $\begin{array}{l}\text { Sentences in } \\
\text { main text:0 } \\
\text { Index pgs.:0 } \\
\text { Review } \\
\text { Questions:0 } \\
\text { Picture:0 }\end{array}$ & $\begin{array}{l}\text { Sentences in } \\
\text { main text:0 } \\
\text { Index pgs.:0 } \\
\text { Review } \\
\text { Questions:0 } \\
\text { Picture:0 }\end{array}$ & $\begin{array}{l}\text { Sentences in } \\
\text { main text:0 } \\
\text { Index pgs.:0 } \\
\text { Review } \\
\text { Questions:0 } \\
\text { Picture:0 }\end{array}$ & $\begin{array}{l}\begin{array}{l}\text { Sentences in } \\
\text { main text:0 }\end{array} \\
\text { Index pgs.:0 } \\
\text { Review } \\
\text { Questions:0 } \\
\text { Picture:0 }\end{array}$ \\
\hline $\begin{array}{l}\text { Gamal Abdal } \\
\text { Nasser }\end{array}$ & & & $\begin{array}{l}\text { Sentences in } \\
\text { main text:2 } \\
\text { Index pgs.:1 } \\
\text { Review } \\
\text { Questions:0 } \\
\text { Picture:0 }\end{array}$ & $\begin{array}{l}\text { Sentences in } \\
\text { main text:2 } \\
\text { Index pgs.:1 } \\
\text { Review } \\
\text { Questions:0 } \\
\text { Picture:0 }\end{array}$ & $\begin{array}{l}\text { Sentences in } \\
\text { main text:5 } \\
\text { Index pgs.:2 } \\
\text { Review } \\
\text { Questions:0 } \\
\text { Picture:0 }\end{array}$ & $\begin{array}{l}\text { Sentences in } \\
\text { main text:6 } \\
\text { Index pgs.:2 } \\
\text { Review } \\
\text { Questions:1 } \\
\text { Picture:0 }\end{array}$ & $\begin{array}{l}\text { Sentences in } \\
\text { main text:5 } \\
\text { Index pgs.:3 } \\
\text { Review } \\
\text { Questions:0 } \\
\text { Picture:0 }\end{array}$ & $\begin{array}{l}\begin{array}{l}\text { Sentences in } \\
\text { main text:16 }\end{array} \\
\text { Index pgs.:7 } \\
\text { Review } \\
\text { Questions:1 } \\
\text { Picture:0 }\end{array}$ \\
\hline
\end{tabular}




\begin{tabular}{|c|c|c|c|c|c|c|c|c|}
\hline $\begin{array}{l}\text { Term: } \\
\text { "Arab (s)" }\end{array}$ & $\begin{array}{l}\text { Sentences in } \\
\text { main text:0 } \\
\text { Index pgs.:0 } \\
\text { Review } \\
\text { Questions:0 } \\
\text { Picture:0 }\end{array}$ & $\begin{array}{l}\text { Sentences in } \\
\text { main text:3 } \\
\text { Index pgs:00 } \\
\text { Review } \\
\text { Questions:0 } \\
\text { Picture:0 }\end{array}$ & $\begin{array}{l}\text { Sentences in } \\
\text { main text:14 } \\
\text { Index pgs::3 } \\
\text { Review } \\
\text { Questions:0 } \\
\text { Picture:0 }\end{array}$ & $\begin{array}{l}\text { Sentences in } \\
\text { main text:17 } \\
\text { Index pgs.:3 } \\
\text { Review } \\
\text { Questions:0 } \\
\text { Picture:0 }\end{array}$ & $\begin{array}{l}\text { Sentences in } \\
\text { main text:6 } \\
\text { Index pgs.:0 } \\
\text { Review } \\
\text { Questions:0 } \\
\text { Picture:0 }\end{array}$ & $\begin{array}{l}\text { Sentences in } \\
\text { main text:5 } \\
\text { Index pgs.:0 } \\
\text { Review } \\
\text { Questions:0 } \\
\text { Picture:0 }\end{array}$ & $\begin{array}{l}\text { Sentences in } \\
\text { main text:6 } \\
\text { Index pgs.:0 } \\
\text { Review } \\
\text { Questions:0 } \\
\text { Picture:0 }\end{array}$ & 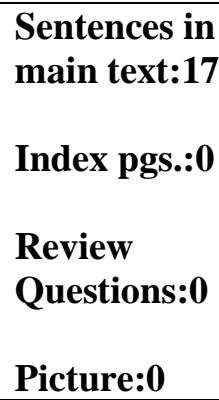 \\
\hline $\begin{array}{l}\text { Term: } \\
\text { "Israel” } \\
\text { and/or } \\
\text { "Israeli" }\end{array}$ & $\begin{array}{l}\text { Sentences in } \\
\text { main text:0 } \\
\text { Index pgs.:0 } \\
\text { Review } \\
\text { Questions:0 } \\
\text { Picture:0 }\end{array}$ & $\begin{array}{l}\text { Sentences in } \\
\text { main text:4 } \\
\text { Index pgs.:0 } \\
\text { Review } \\
\text { Questions:1 } \\
\text { Picture:0 }\end{array}$ & $\begin{array}{l}\text { Sentences in } \\
\text { main text:11 } \\
\text { Index pgs.:3 } \\
\text { Review } \\
\text { Questions:0 } \\
\text { Picture:0 }\end{array}$ & $\begin{array}{l}\text { Sentences in } \\
\text { main text:15 } \\
\text { Index pgs.:3 } \\
\text { Review } \\
\text { Questions:1 } \\
\text { Picture:0 }\end{array}$ & $\begin{array}{l}\text { Sentences in } \\
\text { main text:9 } \\
\text { Index pgs.:2 } \\
\text { Review } \\
\text { Questions:0 } \\
\text { Picture:0 }\end{array}$ & $\begin{array}{l}\text { Sentences in } \\
\text { main text:10 } \\
\text { Index pgs.:5 } \\
\text { Review } \\
\text { Questions:0 } \\
\text { Picture:2 }\end{array}$ & $\begin{array}{l}\text { Sentences in } \\
\text { main text:8 } \\
\text { Index pgs.:3 } \\
\text { Review } \\
\text { Questions:0 } \\
\text { Picture:0 }\end{array}$ & $\begin{array}{l}\text { Sentences in } \\
\text { main text:27 } \\
\text { Index } \\
\text { pgs.:10 } \\
\text { Review } \\
\text { Questions:0 } \\
\text { Picture:2 }\end{array}$ \\
\hline $\begin{array}{l}\text { Term: } \\
\text { "Jews" } \\
\text { and/or } \\
\text { "Jewish" }\end{array}$ & $\begin{array}{l}\text { Sentences in } \\
\text { main text:0 } \\
\text { Index pgs.:0 } \\
\text { Review } \\
\text { Questions:0 } \\
\text { Picture:0 }\end{array}$ & $\begin{array}{l}\text { Sentences in } \\
\text { main text:2 } \\
\text { Index pgs.:0 } \\
\text { Review } \\
\text { Questions:0 } \\
\text { Picture:0 }\end{array}$ & $\begin{array}{l}\text { Sentences in } \\
\text { main text:2 } \\
\text { Index pgs.:9 } \\
\text { Review } \\
\text { Questions:0 } \\
\text { Picyure:0 }\end{array}$ & $\begin{array}{l}\text { Sentences in } \\
\text { main text:4 } \\
\text { Index pgs.:9 } \\
\text { Review } \\
\text { Questions:0 } \\
\text { Picture:0 }\end{array}$ & $\begin{array}{l}\text { Sentences in } \\
\text { main text:0 } \\
\text { Index pgs.:0 } \\
\text { Review } \\
\text { Questions:0 } \\
\text { Picture:0 }\end{array}$ & $\begin{array}{l}\text { Sentences in } \\
\text { main text:1 } \\
\text { Index pgs.:6 } \\
\text { Review } \\
\text { Questions:0 } \\
\text { Picture:0 }\end{array}$ & $\begin{array}{l}\text { Sentences in } \\
\text { main text:2 } \\
\text { Index pgs.:6 } \\
\text { Review } \\
\text { Questions:0 } \\
\text { Picture:0 }\end{array}$ & $\begin{array}{l}\text { Sentences in } \\
\text { main text:3 } \\
\text { Index } \\
\text { pgs.:12 } \\
\text { Review } \\
\text { Questions:0 } \\
\text { Picture:0 }\end{array}$ \\
\hline $\begin{array}{l}\text { Term: } \\
\text { "Palestine" }\end{array}$ & $\begin{array}{l}\text { Sentences in } \\
\text { main text:0 } \\
\text { Index pgs.: } 1\end{array}$ & $\begin{array}{l}\text { Sentences in } \\
\text { main text:2 } \\
\text { Index pgs.:0 }\end{array}$ & $\begin{array}{l}\text { Sentences in } \\
\text { main text:2 } \\
\text { Index pgs.:0 }\end{array}$ & $\begin{array}{l}\text { Sentences in } \\
\text { main text:4 } \\
\text { Index pgs.: } 1\end{array}$ & $\begin{array}{l}\text { Sentences in } \\
\text { main text:0 } \\
\text { Index pgs.:1 }\end{array}$ & $\begin{array}{l}\text { Sentences in } \\
\text { main text:3 } \\
\text { Index pgs.:5 }\end{array}$ & $\begin{array}{l}\text { Sentences in } \\
\text { main text:1 } \\
\text { Index pgs.:0 }\end{array}$ & $\begin{array}{l}\text { Sentences in } \\
\text { main text:4 } \\
\text { Index pgs.:6 }\end{array}$ \\
\hline
\end{tabular}




\begin{tabular}{|c|c|c|c|c|c|c|c|c|}
\hline & $\begin{array}{l}\text { Review } \\
\text { Questions:0 } \\
\text { Picture:1 }\end{array}$ & $\begin{array}{l}\text { Review } \\
\text { Questions:0 } \\
\text { Picture:0 }\end{array}$ & $\begin{array}{l}\text { Review } \\
\text { Questions:0 } \\
\text { Picture:0 }\end{array}$ & $\begin{array}{l}\text { Review } \\
\text { Questions:0 } \\
\text { Picture:1 }\end{array}$ & $\begin{array}{l}\text { Review } \\
\text { Questions:0 } \\
\text { Picture:1 }\end{array}$ & $\begin{array}{l}\text { Review } \\
\text { Questions:0 } \\
\text { Picture:1 }\end{array}$ & $\begin{array}{l}\text { Review } \\
\text { Questions:0 } \\
\text { Picture:0 }\end{array}$ & $\begin{array}{l}\text { Review } \\
\text { Questions:0 } \\
\text { Picture:2 }\end{array}$ \\
\hline $\begin{array}{l}\text { Term: } \\
\text { "Palestinian" }\end{array}$ & $\begin{array}{l}\text { Sentences in } \\
\text { main text:0 } \\
\text { Index pgs.:0 } \\
\text { Review } \\
\text { Questions:0 } \\
\text { Picture:0 }\end{array}$ & $\begin{array}{l}\text { Sentences in } \\
\text { main text:0 } \\
\text { Index pgs.:0 } \\
\text { Review } \\
\text { Questions:0 } \\
\text { Picture:0 }\end{array}$ & $\begin{array}{l}\text { Sentences in } \\
\text { main text:0 } \\
\text { Index pgs.:0 } \\
\text { Review } \\
\text { Questions:0 } \\
\text { Picture:0 }\end{array}$ & $\begin{array}{l}\begin{array}{l}\text { Sentences in } \\
\text { main text:0 }\end{array} \\
\text { Index pgs.:0 } \\
\text { Review } \\
\text { Questions:0 } \\
\text { Picture:0 }\end{array}$ & $\begin{array}{l}\text { Sentences in } \\
\text { main text:0 } \\
\text { Index pgs.:0 } \\
\text { Review } \\
\text { Questions:0 } \\
\text { Picture:0 }\end{array}$ & $\begin{array}{l}\text { Sentences in } \\
\text { main text:0 } \\
\text { Index pgs.:0 } \\
\text { Review } \\
\text { Questions:0 } \\
\text { Picture:0 }\end{array}$ & $\begin{array}{l}\text { Sentences in } \\
\text { main text:0 } \\
\text { Index pgs.:0 } \\
\text { Review } \\
\text { Questions:0 } \\
\text { Picture:0 }\end{array}$ & $\begin{array}{l}\text { Sentences in } \\
\text { main text:0 }\end{array}$ \\
\hline
\end{tabular}

\begin{tabular}{|c|c|c|c|c|c|c|c|c|}
\hline $\begin{array}{r}\text { Topic of } \\
\text { Analysis } \\
\end{array}$ & $\begin{array}{c}\text { Book } 7 \\
\text { HM } 1975 \\
\end{array}$ & $\begin{array}{c}\text { Book 8 } \\
\text { Holt } 1977 \\
\end{array}$ & $\begin{array}{c}\text { Book 9 } \\
\text { PH } 1976 \\
\end{array}$ & $\begin{array}{c}\text { 1970s Books } \\
\text { Total }\end{array}$ & $\begin{array}{c}\text { Book 10 } \\
\text { HM 1986 } \\
\end{array}$ & $\begin{array}{c}\text { Book 11 } \\
\text { Holt } 1986 \\
\end{array}$ & $\begin{array}{l}\text { Book } 12 \\
\text { PH } 1986 \\
\end{array}$ & $\begin{array}{c}\text { 1980s Book } \\
\text { Total }\end{array}$ \\
\hline \multirow[t]{4}{*}{$\begin{array}{l}\text { British } \\
\text { Mandate }\end{array}$} & $\begin{array}{l}\text { Sentences in } \\
\text { main text: } 0\end{array}$ & $\begin{array}{l}\text { Sentences in } \\
\text { main text: } 3\end{array}$ & $\begin{array}{l}\text { Sentences in } \\
\text { main text: } 0\end{array}$ & $\begin{array}{l}\text { Sentences in } \\
\text { main text:3 }\end{array}$ & $\begin{array}{l}\text { Sentences in } \\
\text { main text:0 }\end{array}$ & $\begin{array}{l}\text { Sentences in } \\
\text { main text:3 }\end{array}$ & $\begin{array}{l}\text { Sentences in } \\
\text { main text: } 4\end{array}$ & $\begin{array}{l}\text { Sentences in } \\
\text { main text: } 7\end{array}$ \\
\hline & Index pgs.:0 & Index pgs.:0 & Index pgs.:0 & Index pgs.:0 & Index pgs.:0 & Index pgs.:0 & Index pgs.:0 & Index pgs.:0 \\
\hline & $\begin{array}{l}\text { Review } \\
\text { Questions:0 }\end{array}$ & $\begin{array}{l}\text { Review } \\
\text { Questions:0 }\end{array}$ & $\begin{array}{l}\text { Review } \\
\text { Questions:0 }\end{array}$ & $\begin{array}{l}\text { Review } \\
\text { Questions:0 }\end{array}$ & $\begin{array}{l}\text { Review } \\
\text { Questions:0 }\end{array}$ & $\begin{array}{l}\text { Review } \\
\text { Questions:0 }\end{array}$ & $\begin{array}{l}\text { Review } \\
\text { Questions:0 }\end{array}$ & $\begin{array}{l}\text { Review } \\
\text { Questions:0 }\end{array}$ \\
\hline & Picture:0 & Picture:0 & Picture:0 & Picture:0 & Picture:0 & Picture:0 & Picture:0 & Picture:0 \\
\hline $\begin{array}{l}\text { Balfour } \\
\text { Declaration }\end{array}$ & $\begin{array}{l}\text { Sentences in } \\
\text { main text: } 6\end{array}$ & $\begin{array}{l}\text { Sentences in } \\
\text { main text:5 }\end{array}$ & $\begin{array}{l}\text { Sentences in } \\
\text { main text:3 }\end{array}$ & $\begin{array}{l}\text { Sentences in } \\
\text { main text:14 }\end{array}$ & $\begin{array}{l}\text { Sentences in } \\
\text { main text: } 4\end{array}$ & $\begin{array}{l}\text { Sentences in } \\
\text { main text: } 6\end{array}$ & $\begin{array}{l}\text { Sentences in } \\
\text { main text: } 12\end{array}$ & $\begin{array}{l}\text { Sentences in } \\
\text { main text: } 22\end{array}$ \\
\hline
\end{tabular}




\begin{tabular}{|c|c|c|c|c|c|c|c|c|}
\hline $\begin{array}{l}\text { Establishment } \\
\text { of Israel }\end{array}$ & $\begin{array}{l}\text { Index pgs.:0 } \\
\text { Review } \\
\text { Questions:1 } \\
\text { Picture:0 }\end{array}$ & $\begin{array}{l}\text { Index pgs.:0 } \\
\text { Review } \\
\text { Questions:1 } \\
\text { Picture:0 }\end{array}$ & $\begin{array}{l}\text { Index pgs.:1 } \\
\text { Review } \\
\text { Questions:0 } \\
\text { Picture:0 }\end{array}$ & $\begin{array}{l}\text { Index pgs.:1 } \\
\text { Review } \\
\text { Questions:2 } \\
\text { Picture:0 }\end{array}$ & $\begin{array}{l}\text { Index pgs.:0 } \\
\text { Review } \\
\text { Questions:1 } \\
\text { Picture:0 }\end{array}$ & $\begin{array}{l}\text { Index pgs.:0 } \\
\text { Review } \\
\text { Questions:1 } \\
\text { Picture:1 }\end{array}$ & $\begin{array}{l}\text { Index pgs.:0 } \\
\text { Review } \\
\text { Questions:2 } \\
\text { Picture:0 }\end{array}$ & $\begin{array}{l}\text { Index pgs.:0 } \\
\text { Review } \\
\text { Questions:4 } \\
\text { Picture:1 }\end{array}$ \\
\hline $\begin{array}{l}1956 \text { Suez } \\
\text { Canal Crisis }\end{array}$ & $\begin{array}{l}\text { Sentences in } \\
\text { main text:5 } \\
\text { Index pgs.:2 } \\
\text { Review } \\
\text { Questions:2 } \\
\text { Picture:0 }\end{array}$ & $\begin{array}{l}\text { Sentences in } \\
\text { main text:31 } \\
\text { Index pgs.:4 } \\
\text { Review } \\
\text { Questions:2 } \\
\text { Picture:1 }\end{array}$ & $\begin{array}{l}\text { Sentences in } \\
\text { main text:19 } \\
\text { Index pgs.:1 } \\
\text { Review } \\
\text { Questions:0 } \\
\text { Picture:0 }\end{array}$ & $\begin{array}{l}\text { Sentences in } \\
\text { main text:55 } \\
\text { Index pgs.:7 } \\
\text { Review } \\
\text { Questions:4 } \\
\text { Picture:1 }\end{array}$ & $\begin{array}{l}\text { Sentences in } \\
\text { main text:5 } \\
\text { Index pgs.:3 } \\
\text { Review } \\
\text { Questions:4 } \\
\text { Picture: } 1\end{array}$ & $\begin{array}{l}\text { Sentences in } \\
\text { main text:28 } \\
\text { Index pgs.:4 } \\
\text { Review } \\
\text { Questions:1 } \\
\text { Picture:2 }\end{array}$ & $\begin{array}{l}\text { Sentences in } \\
\text { main text:0 } \\
\text { Index pgs.:0 } \\
\text { Review } \\
\text { Questions:0 } \\
\text { Picture:0 }\end{array}$ & $\begin{array}{l}\text { Sentences in } \\
\text { main text:33 } \\
\text { Index pgs.:7 } \\
\text { Review } \\
\text { Questions:5 } \\
\text { Picture:3 }\end{array}$ \\
\hline $\begin{array}{l}\text { 1967 Six Day } \\
\text { War }\end{array}$ & $\begin{array}{l}\text { Sentences in } \\
\text { main text:3 } \\
\text { Index pgs.:0 } \\
\text { Review } \\
\text { Questions:1 } \\
\text { Picture:0 }\end{array}$ & $\begin{array}{l}\text { Sentences in } \\
\text { main text: } 15 \\
\text { Index pgs.:0 } \\
\text { Review } \\
\text { Questions:0 } \\
\text { Picture:0 }\end{array}$ & $\begin{array}{l}\text { Sentences in } \\
\text { main text:9 } \\
\text { Index pgs.:1 } \\
\text { Review } \\
\text { Questions:0 } \\
\text { Picture:0 }\end{array}$ & $\begin{array}{l}\text { Sentences in } \\
\text { main text:27 } \\
\text { Index pgs.:1 } \\
\text { Review } \\
\text { Questions:1 } \\
\text { Picture:0 }\end{array}$ & $\begin{array}{l}\text { Sentences in } \\
\text { main text:5 } \\
\text { Index pgs.:0 } \\
\text { Review } \\
\text { Questions:1 } \\
\text { Picture:0 }\end{array}$ & $\begin{array}{l}\text { Sentences in } \\
\text { main text:8 } \\
\text { Index pgs.:0 } \\
\text { Review } \\
\text { Questions:0 } \\
\text { Picture: } 1\end{array}$ & $\begin{array}{l}\text { Sentences in } \\
\text { main text:9 } \\
\text { Index pgs.:1 } \\
\text { Review } \\
\text { Questions:0 } \\
\text { Picture:1 }\end{array}$ & $\begin{array}{l}\text { Sentences in } \\
\text { main text:20 } \\
\text { Index pgs.:1 } \\
\text { Review } \\
\text { Questions:1 } \\
\text { Picture:2 }\end{array}$ \\
\hline $\begin{array}{l}1973 \text { Yom } \\
\text { Kippur War }\end{array}$ & $\begin{array}{l}\text { Sentences in } \\
\text { main text:15 } \\
\text { Index pgs.:0 } \\
\text { Review } \\
\text { Questions:0 }\end{array}$ & $\begin{array}{l}\text { Sentences in } \\
\text { main text:17 } \\
\text { Index pgs.:0 } \\
\text { Review } \\
\text { Questions:2 }\end{array}$ & $\begin{array}{l}\text { Sentences in } \\
\text { main text:3 } \\
\text { Index pgs.:0 } \\
\text { Review } \\
\text { Questions:0 }\end{array}$ & $\begin{array}{l}\text { Sentences in } \\
\text { main text:35 } \\
\text { Index pgs.:0 } \\
\text { Review } \\
\text { Questions:2 }\end{array}$ & $\begin{array}{l}\text { Sentences in } \\
\text { main text:10 } \\
\text { Index pgs.:2 } \\
\text { Review } \\
\text { Questions:0 }\end{array}$ & $\begin{array}{l}\text { Sentences in } \\
\text { main text:20 } \\
\text { Index pgs.:2 } \\
\text { Review } \\
\text { Questions:3 }\end{array}$ & $\begin{array}{l}\text { Sentences in } \\
\text { main text:24 } \\
\text { Index pgs.:2 } \\
\text { Review } \\
\text { Questions:1 }\end{array}$ & $\begin{array}{l}\text { Sentences in } \\
\text { main text:54 } \\
\text { Index pgs.:6 } \\
\text { Review } \\
\text { Questions:4 }\end{array}$ \\
\hline
\end{tabular}




\begin{tabular}{|c|c|c|c|c|c|c|c|c|}
\hline & Picture:0 & Picture:1 & Picture:0 & Picture:1 & Picture:0 & Picture:0 & Picture: 1 & Picture:1 \\
\hline $\begin{array}{l}1979 \text { Camp } \\
\text { David Accords }\end{array}$ & & & & & $\begin{array}{l}\text { Sentences in } \\
\text { main text:0 } \\
\text { Index pgs.:0 } \\
\text { Review } \\
\text { Questions:0 } \\
\text { Picture:0 }\end{array}$ & $\begin{array}{l}\text { Sentences in } \\
\text { main text:23 } \\
\text { Index pgs.:1 } \\
\text { Review } \\
\text { Questions:1 } \\
\text { Picture:2 }\end{array}$ & $\begin{array}{l}\text { Sentences in } \\
\text { main text:17 } \\
\text { Index pgs.:1 } \\
\text { Review } \\
\text { Questions:3 } \\
\text { Picture:3 }\end{array}$ & $\begin{array}{l}\text { Sentences in } \\
\text { main text:40 } \\
\text { Index pgs.:2 } \\
\text { Review } \\
\text { Questions:4 } \\
\text { Picture:5 }\end{array}$ \\
\hline $\begin{array}{l}\text { 1980's conflict } \\
\text { in Lebanon }\end{array}$ & & & & & $\begin{array}{l}\text { Sentences in } \\
\text { main text:0 } \\
\text { Index pgs.:0 } \\
\text { Review } \\
\text { Questions:0 } \\
\text { Picture:0 }\end{array}$ & $\begin{array}{l}\text { Sentences in } \\
\text { main text:21 } \\
\text { Index pgs.:3 } \\
\text { Review } \\
\text { Questions:2 } \\
\text { Picture:0 }\end{array}$ & $\begin{array}{l}\text { Sentences in } \\
\text { main text:25 } \\
\text { Index pgs.:3 } \\
\text { Review } \\
\text { Questions:0 } \\
\text { Picture:2 }\end{array}$ & $\begin{array}{l}\begin{array}{l}\text { Sentences in } \\
\text { main text:46 }\end{array} \\
\text { Index pgs.:6 } \\
\text { Review } \\
\text { Questions:2 } \\
\text { Picture:2 }\end{array}$ \\
\hline $\begin{array}{l}\text { Menachem } \\
\text { Begin }\end{array}$ & & & & & $\begin{array}{l}\text { Sentences in } \\
\text { main text: } 0 \\
\text { Index pgs.:0 } \\
\text { Review } \\
\text { Questions: } 0 \\
\text { Picture: } 0\end{array}$ & $\begin{array}{l}\text { Sentences in } \\
\text { main text:5 } \\
\text { Index pgs.:1 } \\
\text { Review } \\
\text { Questions:1 } \\
\text { Picture:1 }\end{array}$ & $\begin{array}{l}\text { Sentences in } \\
\text { main text:4 } \\
\text { Index pgs.:1 } \\
\text { Review } \\
\text { Questions:0 } \\
\text { Picture:1 }\end{array}$ & $\begin{array}{l}\begin{array}{l}\text { Sentences in } \\
\text { main text:9 }\end{array} \\
\text { Index pgs.:2 } \\
\text { Review } \\
\text { Questions:1 } \\
\text { Picture:2 }\end{array}$ \\
\hline Anwar Sadat & & & & & $\begin{array}{l}\text { Sentences in } \\
\text { main text:0 }\end{array}$ & $\begin{array}{l}\text { Sentences in } \\
\text { main text: } 7\end{array}$ & $\begin{array}{l}\text { Sentences in } \\
\text { main text: } 6\end{array}$ & $\begin{array}{l}\text { Sentences in } \\
\text { main text:13 }\end{array}$ \\
\hline
\end{tabular}




\begin{tabular}{|c|c|c|c|c|c|c|c|c|}
\hline & & & & & $\begin{array}{l}\text { Index pgs.:1 } \\
\text { Review } \\
\text { Questions:1 } \\
\text { Picture: } 0\end{array}$ & $\begin{array}{l}\text { Index pgs.:1 } \\
\text { Review } \\
\text { Questions:1 } \\
\text { Picture: } 1\end{array}$ & $\begin{array}{l}\text { Index pgs.:1 } \\
\text { Review } \\
\text { Questions: } 0 \\
\text { Picture: } 1\end{array}$ & $\begin{array}{l}\text { Index pgs.:3 } \\
\text { Review } \\
\text { Questions:1 } \\
\text { Picture:2 }\end{array}$ \\
\hline $\begin{array}{l}\text { Gamal Abdal } \\
\text { Nasser }\end{array}$ & $\begin{array}{l}\text { Sentences in } \\
\text { main text:0 } \\
\text { Index pgs.:0 } \\
\text { Review } \\
\text { Questions:0 } \\
\text { Picture:0 }\end{array}$ & $\begin{array}{l}\text { Sentences in } \\
\text { main text:7 } \\
\text { Index pgs.:1 } \\
\text { Review } \\
\text { Questions:1 } \\
\text { Picture:0 }\end{array}$ & $\begin{array}{l}\text { Sentences in } \\
\text { main text:2 } \\
\text { Index pgs.:3 } \\
\text { Review } \\
\text { Questions:0 } \\
\text { Picture:0 }\end{array}$ & $\begin{array}{l}\text { Sentences in } \\
\text { main text:9 } \\
\text { Index pgs.:4 } \\
\text { Review } \\
\text { Questions:1 } \\
\text { Picture:0 }\end{array}$ & $\begin{array}{l}\text { Sentences in } \\
\text { main text:0 } \\
\text { Index pgs.:0 } \\
\text { Review } \\
\text { Questions:0 } \\
\text { Picture:0 }\end{array}$ & $\begin{array}{l}\text { Sentences in } \\
\text { main text:6 } \\
\text { Index pgs.:1 } \\
\text { Review } \\
\text { Questions:1 } \\
\text { Picture:0 }\end{array}$ & $\begin{array}{l}\text { Sentences in } \\
\text { main text:0 } \\
\text { Index pgs.:0 } \\
\text { Review } \\
\text { Questions:0 } \\
\text { Picture:0 } \\
\end{array}$ & $\begin{array}{l}\begin{array}{l}\text { Sentences in } \\
\text { main text:6 }\end{array} \\
\text { Index pgs.:1 } \\
\text { Review } \\
\text { Questions:1 } \\
\text { Picture:0 } \\
\end{array}$ \\
\hline $\begin{array}{l}\text { Term: } \\
\text { "Arab (s)" }\end{array}$ & $\begin{array}{l}\text { Sentences in } \\
\text { main text:13 } \\
\text { Index pgs.:4 } \\
\text { Review } \\
\text { Questions:0 } \\
\text { Picture:0 }\end{array}$ & $\begin{array}{l}\text { Sentences in } \\
\text { main text:14 } \\
\text { Index pgs.:9 } \\
\text { Review } \\
\text { Questions:1 } \\
\text { Picture:0 }\end{array}$ & $\begin{array}{l}\text { Sentences in } \\
\text { main text:6 } \\
\text { Index pgs.:0 } \\
\text { Review } \\
\text { Questions:0 } \\
\text { Picture:0 }\end{array}$ & $\begin{array}{l}\text { Sentences in } \\
\text { main text:33 } \\
\text { Index } \\
\text { pgs.:13 } \\
\text { Review } \\
\text { Questions:1 } \\
\text { Picture:0 }\end{array}$ & $\begin{array}{l}\text { Sentences in } \\
\text { main text:7 } \\
\text { Index pgs.:4 } \\
\text { Review } \\
\text { Questions:0 } \\
\text { Picture:0 }\end{array}$ & $\begin{array}{l}\text { Sentences in } \\
\text { main text:24 } \\
\text { Index pgs.:7 } \\
\text { Review } \\
\text { Questions:1 } \\
\text { Picture:1 }\end{array}$ & $\begin{array}{l}\text { Sentences in } \\
\text { main text:25 } \\
\text { Index pgs.:5 } \\
\text { Review } \\
\text { Questions:0 } \\
\text { Picture:0 }\end{array}$ & $\begin{array}{l}\text { Sentences in } \\
\text { main text:54 } \\
\text { Index } \\
\text { pgs.:16 } \\
\text { Review } \\
\text { Questions:1 } \\
\text { Picture:1 }\end{array}$ \\
\hline $\begin{array}{l}\text { Term: } \\
\text { "Israel" } \\
\text { and/or }\end{array}$ & $\begin{array}{l}\text { Sentences in } \\
\text { main text: } 16 \\
\text { Index pgs.:5 } \\
\text { Review }\end{array}$ & $\begin{array}{l}\text { Sentences in } \\
\text { main text:39 } \\
\text { Index pgs.:8 } \\
\text { Review }\end{array}$ & $\begin{array}{l}\text { Sentences in } \\
\text { main text:10 } \\
\text { Index pgs.:5 } \\
\text { Review }\end{array}$ & $\begin{array}{l}\text { Sentences in } \\
\text { main text:65 } \\
\text { Index } \\
\text { pgs.:18 }\end{array}$ & $\begin{array}{l}\text { Sentences in } \\
\text { main text:14 } \\
\text { Index pgs.:5 } \\
\text { Review }\end{array}$ & $\begin{array}{l}\text { Sentences in } \\
\text { main text:52 } \\
\text { Index pgs.:5 } \\
\text { Review }\end{array}$ & $\begin{array}{l}\text { Sentences in } \\
\text { main text:46 } \\
\text { Index pgs.:9 } \\
\text { Review }\end{array}$ & $\begin{array}{l}\begin{array}{l}\text { Sentences in } \\
\text { main } \\
\text { text:110 }\end{array} \\
\text { Index } \\
\text { pgs.:19 }\end{array}$ \\
\hline
\end{tabular}




\begin{tabular}{|c|c|c|c|c|c|c|c|c|}
\hline "Israeli" & $\begin{array}{l}\text { Questions:1 } \\
\text { Picture:0 }\end{array}$ & $\begin{array}{l}\text { Questions:1 } \\
\text { Picture:0 }\end{array}$ & $\begin{array}{l}\text { Questions:0 } \\
\text { Picture:0 }\end{array}$ & $\begin{array}{l}\text { Review } \\
\text { Questions:2 } \\
\text { Picture:0 }\end{array}$ & $\begin{array}{l}\text { Questions:2 } \\
\text { Picture:1 }\end{array}$ & $\begin{array}{l}\text { Questions:3 } \\
\text { Picture:0 }\end{array}$ & $\begin{array}{l}\text { Questions:1 } \\
\text { Picture:1 }\end{array}$ & $\begin{array}{l}\text { Review } \\
\text { Questions:6 } \\
\text { Picture:2 }\end{array}$ \\
\hline $\begin{array}{l}\text { Term: } \\
\text { "Jews" } \\
\text { and/or } \\
\text { "Jewish" }\end{array}$ & $\begin{array}{l}\text { Sentences in } \\
\text { main text:1 } \\
\text { Index pgs.:1 } \\
\text { Review } \\
\text { Questions:0 } \\
\text { Picture:0 }\end{array}$ & $\begin{array}{l}\text { Sentences in } \\
\text { main text:3 } \\
\text { Index pgs.:7 } \\
\text { Review } \\
\text { Questions:0 } \\
\text { Picture:0 }\end{array}$ & $\begin{array}{l}\text { Sentences in } \\
\text { main text:3 } \\
\text { Index pgs.:11 } \\
\text { Review } \\
\text { Questions:0 } \\
\text { Picture:0 }\end{array}$ & $\begin{array}{l}\text { Sentences in } \\
\text { main text:7 } \\
\text { Index } \\
\text { pgs.:19 } \\
\text { Review } \\
\text { Questions:0 } \\
\text { Picture:0 }\end{array}$ & $\begin{array}{l}\text { Sentences in } \\
\text { main text:1 } \\
\text { Index pgs.:5 } \\
\text { Review } \\
\text { Questions:0 } \\
\text { Picture:0 }\end{array}$ & $\begin{array}{l}\text { Sentences in } \\
\text { main text:5 } \\
\text { Index pgs.:5 } \\
\text { Review } \\
\text { Questions:0 } \\
\text { Picture:0 }\end{array}$ & $\begin{array}{l}\text { Sentences in } \\
\text { main text:7 } \\
\text { Index pgs.:15 } \\
\text { Review } \\
\text { Questions:0 } \\
\text { Picture:0 }\end{array}$ & $\begin{array}{l}\text { Sentences in } \\
\text { main text:13 } \\
\text { Index } \\
\text { pgs.:25 } \\
\text { Review } \\
\text { Questions:0 } \\
\text { Picture:0 }\end{array}$ \\
\hline $\begin{array}{l}\text { Term: } \\
\text { "Palestine" }\end{array}$ & $\begin{array}{l}\text { Sentences in } \\
\text { main text:0 } \\
\text { Index pgs.:0 } \\
\text { Review } \\
\text { Questions:0 } \\
\text { Picture:0 }\end{array}$ & $\begin{array}{l}\text { Sentences in } \\
\text { main text:2 } \\
\text { Index pgs.:2 } \\
\text { Review } \\
\text { Questions:0 } \\
\text { Picture:0 }\end{array}$ & $\begin{array}{l}\text { Sentences in } \\
\text { main text:1 } \\
\text { Index pgs.:1 } \\
\text { Review } \\
\text { Questions:0 } \\
\text { Picture:0 }\end{array}$ & $\begin{array}{l}\begin{array}{l}\text { Sentences in } \\
\text { main text:3 }\end{array} \\
\text { Index pgs.:3 } \\
\text { Review } \\
\text { Questions:0 } \\
\text { Picture:0 }\end{array}$ & $\begin{array}{l}\text { Sentences in } \\
\text { main text:0 } \\
\text { Index pgs.:0 } \\
\text { Review } \\
\text { Questions:0 } \\
\text { Picture:0 }\end{array}$ & $\begin{array}{l}\text { Sentences in } \\
\text { main text:6 } \\
\text { Index pgs.:2 } \\
\text { Review } \\
\text { Questions:1 } \\
\text { Picture:0 }\end{array}$ & $\begin{array}{l}\text { Sentences in } \\
\text { main text:8 } \\
\text { Index pgs.:0 } \\
\text { Review } \\
\text { Questions:0 } \\
\text { Picture: } 1\end{array}$ & $\begin{array}{l}\text { Sentences in } \\
\text { main text:14 } \\
\text { Index pgs.:2 } \\
\text { Review } \\
\text { Questions:1 } \\
\text { Picture:1 }\end{array}$ \\
\hline $\begin{array}{l}\text { Term: } \\
\text { "Palestinian" }\end{array}$ & $\begin{array}{l}\text { Sentences in } \\
\text { main text:0 } \\
\text { Index pgs.:0 } \\
\text { Review }\end{array}$ & $\begin{array}{l}\text { Sentences in } \\
\text { main text: } 1 \\
\text { Index pgs.:0 } \\
\text { Review }\end{array}$ & $\begin{array}{l}\text { Sentences in } \\
\text { main text:0 } \\
\text { Index pgs.:0 } \\
\text { Review }\end{array}$ & $\begin{array}{l}\begin{array}{l}\text { Sentences in } \\
\text { main text:2 }\end{array} \\
\text { Index pgs.:0 } \\
\text { Review }\end{array}$ & $\begin{array}{l}\text { Sentences in } \\
\text { main text:0 } \\
\text { Index pgs.:0 } \\
\text { Review }\end{array}$ & $\begin{array}{l}\text { Sentences in } \\
\text { main text:4 } \\
\text { Index pgs.:0 } \\
\text { Review }\end{array}$ & $\begin{array}{l}\text { Sentences in } \\
\text { main text: } 4 \\
\text { Index pgs.:2 } \\
\text { Review }\end{array}$ & $\begin{array}{l}\text { Sentences in } \\
\text { main text:8 } \\
\text { Index pgs.:2 } \\
\text { Review }\end{array}$ \\
\hline
\end{tabular}




\begin{tabular}{|l|l|l|l|l|l|l|l|l|}
\hline & Questions:0 & Questions:0 & Questions:0 & Questions:0 & Questions:0 & Questions:0 & Questions:1 & Questions:1 \\
& Picture:0 & Picture:0 & Picture:0 & Picture:0 & Picture:0 & Picture:0 & Picture:0 & Picture:0 \\
\hline
\end{tabular}

\begin{tabular}{|c|c|c|c|c|c|c|c|c|}
\hline $\begin{array}{l}\text { Topic of } \\
\text { Analysis }\end{array}$ & $\begin{array}{c}\text { Book 13 } \\
\text { HM } 1996 \\
\end{array}$ & $\begin{array}{c}\text { Book } 14 \\
\text { Holt } 1995 \\
\end{array}$ & $\begin{array}{l}\text { Book } 15 \\
\text { PH } 1995 \\
\end{array}$ & $\begin{array}{l}\text { 1990s Books } \\
\text { Total }\end{array}$ & $\begin{array}{c}\text { Book 16 } \\
\text { HM 2003 }\end{array}$ & $\begin{array}{c}\text { Book 17 } \\
\text { Holt } 2003 \\
\end{array}$ & $\begin{array}{l}\text { Book 18 } \\
\text { PH } 2005 \\
\end{array}$ & $\begin{array}{c}\text { 2000s Book } \\
\text { Total }\end{array}$ \\
\hline $\begin{array}{l}\text { British } \\
\text { Mandate }\end{array}$ & $\begin{array}{l}\text { Sentences in } \\
\text { main text:2 } \\
\text { Index pgs.:1 } \\
\text { Review } \\
\text { Questions:0 } \\
\text { Picture:0 }\end{array}$ & $\begin{array}{l}\text { Sentences in } \\
\text { main text:13 } \\
\text { Index pgs.:1 } \\
\text { Review } \\
\text { Questions:1 } \\
\text { Picture:2 }\end{array}$ & $\begin{array}{l}\text { Sentences in } \\
\text { main text:0 } \\
\text { Index pgs.:0 } \\
\text { Review } \\
\text { Questions:0 } \\
\text { Picture:0 }\end{array}$ & $\begin{array}{l}\text { Sentences in } \\
\text { main text:15 } \\
\text { Index pgs.:2 } \\
\text { Review } \\
\text { Questions:1 } \\
\text { Picture:2 }\end{array}$ & $\begin{array}{l}\text { Sentences in } \\
\text { main text:0 } \\
\text { Index pgs.:1 } \\
\text { Review } \\
\text { Questions:0 } \\
\text { Picture:0 }\end{array}$ & $\begin{array}{l}\text { Sentences in } \\
\text { main text:8 } \\
\text { Index pgs.:0 } \\
\text { Review } \\
\text { Questions:2 } \\
\text { Picture:0 }\end{array}$ & $\begin{array}{l}\text { Sentences in } \\
\text { main text:2 } \\
\text { Index pgs.:0 } \\
\text { Review } \\
\text { Questions:0 } \\
\text { Picture:0 }\end{array}$ & $\begin{array}{l}\text { Sentences in } \\
\text { main text:10 } \\
\text { Index pgs.:1 } \\
\text { Review } \\
\text { Questions:2 } \\
\text { Picture:0 }\end{array}$ \\
\hline $\begin{array}{l}\text { Balfour } \\
\text { Declaration } \\
\text { and/or } \\
\text { Establishment } \\
\text { of Israel }\end{array}$ & $\begin{array}{l}\text { Sentences in } \\
\text { main text:2 } \\
\text { Index pgs.:0 } \\
\text { Review } \\
\text { Questions:0 } \\
\text { Picture:0 }\end{array}$ & $\begin{array}{l}\text { Sentences in } \\
\text { main text:17 } \\
\text { Index pgs.:5 } \\
\text { Review } \\
\text { Questions:5 } \\
\text { Picture:3 }\end{array}$ & $\begin{array}{l}\text { Sentences in } \\
\text { main text:6 } \\
\text { Index pgs.:0 } \\
\text { Review } \\
\text { Questions:1 } \\
\text { Picture:2 }\end{array}$ & $\begin{array}{l}\text { Sentences in } \\
\text { main text:25 } \\
\text { Index pgs.:5 } \\
\text { Review } \\
\text { Questions:6 } \\
\text { Picture:5 }\end{array}$ & $\begin{array}{l}\text { Sentences in } \\
\text { main text:3 } \\
\text { Index pgs.:1 } \\
\text { Review } \\
\text { Questions:0 } \\
\text { Picture:1 }\end{array}$ & $\begin{array}{l}\text { Sentences in } \\
\text { main text:23 } \\
\text { Index pgs.:3 } \\
\text { Review } \\
\text { Questions:5 } \\
\text { Picture:2 }\end{array}$ & $\begin{array}{l}\text { Sentences in } \\
\text { main text:9 } \\
\text { Index pgs.:0 } \\
\text { Review } \\
\text { Questions:0 } \\
\text { Picture:1 }\end{array}$ & $\begin{array}{l}\text { Sentences in } \\
\text { main text:32 } \\
\text { Index pgs.:4 } \\
\text { Review } \\
\text { Questions:5 } \\
\text { Picture:4 }\end{array}$ \\
\hline $\begin{array}{l}1956 \text { Suez } \\
\text { Canal Crisis }\end{array}$ & $\begin{array}{l}\text { Sentences in } \\
\text { main text: } 22\end{array}$ & $\begin{array}{l}\text { Sentences in } \\
\text { main text:16 }\end{array}$ & $\begin{array}{l}\text { Sentences in } \\
\text { main text:0 }\end{array}$ & $\begin{array}{l}\text { Sentences in } \\
\text { main text:38 }\end{array}$ & $\begin{array}{l}\text { Sentences in } \\
\text { main text:13 }\end{array}$ & $\begin{array}{l}\text { Sentences in } \\
\text { main text: } 12\end{array}$ & $\begin{array}{l}\text { Sentences in } \\
\text { main text: } 8\end{array}$ & $\begin{array}{l}\text { Sentences in } \\
\text { main text:33 }\end{array}$ \\
\hline
\end{tabular}




\begin{tabular}{|c|c|c|c|c|c|c|c|c|}
\hline & $\begin{array}{l}\text { Index pgs.:4 } \\
\text { Review } \\
\text { Questions:2 } \\
\text { Picture:1 }\end{array}$ & $\begin{array}{l}\text { Index pgs.:1 } \\
\text { Review } \\
\text { Questions:0 } \\
\text { Picture:1 }\end{array}$ & $\begin{array}{l}\text { Index pgs.:0 } \\
\text { Review } \\
\text { Questions:0 } \\
\text { Picture:0 }\end{array}$ & $\begin{array}{l}\text { Index pgs.:5 } \\
\text { Review } \\
\text { Questions:2 } \\
\text { Picture:2 } \\
\end{array}$ & $\begin{array}{l}\text { Index pgs.: } 1 \\
\text { Review } \\
\text { Questions:0 } \\
\text { Picture:0 }\end{array}$ & $\begin{array}{l}\text { Index pgs.:1 } \\
\text { Review } \\
\text { Questions:0 } \\
\text { Picture:0 }\end{array}$ & $\begin{array}{l}\text { Index pgs.:1 } \\
\text { Review } \\
\text { Questions:2 } \\
\text { Picture:1 }\end{array}$ & $\begin{array}{l}\text { Index pgs.:3 } \\
\text { Review } \\
\text { Questions:2 } \\
\text { Picture:1 }\end{array}$ \\
\hline $\begin{array}{l}1967 \text { Six Day } \\
\text { War }\end{array}$ & $\begin{array}{l}\text { Sentences in } \\
\text { main text:1 } \\
\text { Index pgs.:0 } \\
\text { Review } \\
\text { Questions:0 } \\
\text { Picture:2 }\end{array}$ & $\begin{array}{l}\text { Sentences in } \\
\text { main text:5 } \\
\text { Index pgs.:1 } \\
\text { Review } \\
\text { Questions:0 } \\
\text { Picture:0 }\end{array}$ & $\begin{array}{l}\text { Sentences in } \\
\text { main text:0 } \\
\text { Index pgs.:0 } \\
\text { Review } \\
\text { Questions:0 } \\
\text { Picture:2 }\end{array}$ & $\begin{array}{l}\text { Sentences in } \\
\text { main text:6 } \\
\text { Index pgs.:1 } \\
\text { Review } \\
\text { Questions:0 } \\
\text { Picture:4 }\end{array}$ & $\begin{array}{l}\text { Sentences in } \\
\text { main text:1 } \\
\text { Index pgs.:0 } \\
\text { Review } \\
\text { Questions:0 } \\
\text { Picture:0 }\end{array}$ & $\begin{array}{l}\text { Sentences in } \\
\text { main text:4 } \\
\text { Index pgs.:1 } \\
\text { Review } \\
\text { Questions:0 } \\
\text { Picture:0 }\end{array}$ & $\begin{array}{l}\text { Sentences in } \\
\text { main text:1 } \\
\text { Index pgs.:1 } \\
\text { Review } \\
\text { Questions:0 } \\
\text { Picture:0 }\end{array}$ & $\begin{array}{l}\text { Sentences in } \\
\text { main text:6 } \\
\text { Index pgs.:2 } \\
\text { Review } \\
\text { Questions:0 } \\
\text { Picture:0 }\end{array}$ \\
\hline $\begin{array}{l}1973 \text { Yom } \\
\text { Kippur War }\end{array}$ & $\begin{array}{l}\text { Sentences in } \\
\text { main text:10 } \\
\text { Index pgs.:3 } \\
\text { Review } \\
\text { Questions:2 } \\
\text { Picture: } 1\end{array}$ & $\begin{array}{l}\text { Sentences in } \\
\text { main text:11 } \\
\text { Index pgs.:1 } \\
\text { Review } \\
\text { Questions:0 } \\
\text { Picture:1 }\end{array}$ & $\begin{array}{l}\text { Sentences in } \\
\text { main text:6 } \\
\text { Index pgs.:0 } \\
\text { Review } \\
\text { Questions:2 } \\
\text { Picture:1 }\end{array}$ & $\begin{array}{l}\text { Sentences in } \\
\text { main text:27 } \\
\text { Index pgs.:4 } \\
\text { Review } \\
\text { Questions:4 } \\
\text { Picture:3 }\end{array}$ & $\begin{array}{l}\text { Sentences in } \\
\text { main text:12 } \\
\text { Index pgs.:1 } \\
\text { Review } \\
\text { Questions:0 } \\
\text { Picture:1 }\end{array}$ & $\begin{array}{l}\text { Sentences in } \\
\text { main text:9 } \\
\text { Index pgs.:0 } \\
\text { Review } \\
\text { Questions:0 } \\
\text { Picture:2 }\end{array}$ & $\begin{array}{l}\text { Sentences in } \\
\text { main text:9 } \\
\text { Index pgs.:0 } \\
\text { Review } \\
\text { Questions:0 } \\
\text { Picture:0 }\end{array}$ & $\begin{array}{l}\begin{array}{l}\text { Sentences in } \\
\text { main text:30 }\end{array} \\
\text { Index pgs.:1 } \\
\text { Review } \\
\text { Questions:0 } \\
\text { Picture:3 }\end{array}$ \\
\hline $\begin{array}{l}1979 \text { Camp } \\
\text { David Accords }\end{array}$ & $\begin{array}{l}\text { Sentences in } \\
\text { main text: } 21 \\
\text { Index pgs.:5 } \\
\text { Review }\end{array}$ & $\begin{array}{l}\text { Sentences in } \\
\text { main text:27 } \\
\text { Index pgs.:2 } \\
\text { Review }\end{array}$ & $\begin{array}{l}\text { Sentences in } \\
\text { main text:19 } \\
\text { Index pgs.:1 } \\
\text { Review }\end{array}$ & $\begin{array}{l}\text { Sentences in } \\
\text { main text:67 } \\
\text { Index pgs.:8 } \\
\text { Review }\end{array}$ & $\begin{array}{l}\text { Sentences in } \\
\text { main text:12 } \\
\text { Index pgs.:2 } \\
\text { Review }\end{array}$ & $\begin{array}{l}\text { Sentences in } \\
\text { main text:10 } \\
\text { Index pgs.: } 1 \\
\text { Review }\end{array}$ & $\begin{array}{l}\text { Sentences in } \\
\text { main text:15 } \\
\text { Index pgs.:1 } \\
\text { Review }\end{array}$ & $\begin{array}{l}\text { Sentences in } \\
\text { main text:37 } \\
\text { Index pgs.:4 } \\
\text { Review }\end{array}$ \\
\hline
\end{tabular}




\begin{tabular}{|c|c|c|c|c|c|c|c|c|}
\hline & $\begin{array}{l}\text { Questions:5 } \\
\text { Picture:3 }\end{array}$ & $\begin{array}{l}\text { Questions:1 } \\
\text { Picture:2 }\end{array}$ & $\begin{array}{l}\text { Questions:5 } \\
\text { Picture:1 }\end{array}$ & $\begin{array}{l}\text { Questions:11 } \\
\text { Picture:6 }\end{array}$ & $\begin{array}{l}\text { Questions:3 } \\
\text { Picture:3 }\end{array}$ & $\begin{array}{l}\text { Questions:4 } \\
\text { Picture:1 }\end{array}$ & $\begin{array}{l}\text { Questions:6 } \\
\text { Picture:2 }\end{array}$ & $\begin{array}{l}\text { Questions:13 } \\
\text { Picture:6 }\end{array}$ \\
\hline $\begin{array}{l}1980 \text { 's conflict } \\
\text { in Lebanon }\end{array}$ & $\begin{array}{l}\text { Sentences in } \\
\text { main text:11 } \\
\text { Index pgs.:4 } \\
\text { Review } \\
\text { Questions:0 } \\
\text { Picture:0 }\end{array}$ & $\begin{array}{l}\text { Sentences in } \\
\text { main text:0 } \\
\text { Index pgs.:1 } \\
\text { Review } \\
\text { Questions:0 } \\
\text { Picture:0 }\end{array}$ & $\begin{array}{l}\text { Sentences in } \\
\text { main text:6 } \\
\text { Index pgs.:0 } \\
\text { Review } \\
\text { Questions:0 } \\
\text { Picture:1 }\end{array}$ & $\begin{array}{l}\text { Sentences in } \\
\text { main text:17 } \\
\text { Index pgs.:5 } \\
\text { Review } \\
\text { Questions:0 } \\
\text { Picture:1 }\end{array}$ & $\begin{array}{l}\text { Sentences in } \\
\text { main text:0 } \\
\text { Index pgs.:0 } \\
\text { Review } \\
\text { Questions:0 } \\
\text { Picture:0 }\end{array}$ & $\begin{array}{l}\text { Sentences in } \\
\text { main text:0 } \\
\text { Index pgs.:0 } \\
\text { Review } \\
\text { Questions:0 } \\
\text { Picture:0 }\end{array}$ & $\begin{array}{l}\text { Sentences in } \\
\text { main text:8 } \\
\text { Index pgs.:1 } \\
\text { Review } \\
\text { Questions:0 } \\
\text { Picture:1 }\end{array}$ & $\begin{array}{l}\text { Sentences in } \\
\text { main text:8 } \\
\text { Index pgs.:1 } \\
\text { Review } \\
\text { Questions:0 } \\
\text { Picture:1 }\end{array}$ \\
\hline $\begin{array}{l}\text { 1991-1994 } \\
\text { peace talks }\end{array}$ & $\begin{array}{l}\text { Sentences in } \\
\text { main text:21 } \\
\text { Index pgs.:0 } \\
\text { Review } \\
\text { Questions:0 } \\
\text { Picture:1 }\end{array}$ & $\begin{array}{l}\text { Sentences in } \\
\text { main text:8 } \\
\text { Index pgs.:0 } \\
\text { Review } \\
\text { Questions:0 } \\
\text { Picture:1 }\end{array}$ & $\begin{array}{l}\text { Sentences in } \\
\text { main text:20 } \\
\text { Index pgs.:0 } \\
\text { Review } \\
\text { Questions:5 } \\
\text { Picture:4 }\end{array}$ & $\begin{array}{l}\text { Sentences in } \\
\text { main text:49 } \\
\text { Index pgs.:0 } \\
\text { Review } \\
\text { Questions:5 } \\
\text { Picture:6 }\end{array}$ & $\begin{array}{l}\text { Sentences in } \\
\text { main text:0 } \\
\text { Index pgs.:0 } \\
\text { Review } \\
\text { Questions:0 } \\
\text { Picture:0 }\end{array}$ & $\begin{array}{l}\text { Sentences in } \\
\text { main text:13 } \\
\text { Index pgs.:0 } \\
\text { Review } \\
\text { Questions:3 } \\
\text { Picture:1 }\end{array}$ & $\begin{array}{l}\text { Sentences in } \\
\text { main text:9 } \\
\text { Index pgs.:0 } \\
\text { Review } \\
\text { Questions:0 } \\
\text { Picture:0 }\end{array}$ & $\begin{array}{l}\text { Sentences in } \\
\text { main text:22 } \\
\text { Index pgs.:0 } \\
\text { Review } \\
\text { Questions:3 } \\
\text { Picture:1 }\end{array}$ \\
\hline $\begin{array}{l}\text { Post 9/11 } \\
\text { Arab-Israeli } \\
\text { conflict }\end{array}$ & & & & & $\begin{array}{l}\text { Sentences in } \\
\text { main text:0 } \\
\text { Index pgs.:0 } \\
\text { Review }\end{array}$ & $\begin{array}{l}\text { Sentences in } \\
\text { main text:0 } \\
\text { Index pgs.:0 } \\
\text { Review }\end{array}$ & $\begin{array}{l}\text { Sentences in } \\
\text { main text: } 8 \\
\text { Index pgs.:0 } \\
\text { Review }\end{array}$ & $\begin{array}{l}\text { Sentences in } \\
\text { main text:8 } \\
\text { Index pgs.:0 } \\
\text { Review }\end{array}$ \\
\hline
\end{tabular}




\begin{tabular}{|c|c|c|c|c|c|c|c|c|}
\hline & & & & & $\begin{array}{l}\text { Questions:0 } \\
\text { Picture:0 }\end{array}$ & $\begin{array}{l}\text { Questions:0 } \\
\text { Picture:0 }\end{array}$ & $\begin{array}{l}\text { Questions:1 } \\
\text { Picture:0 }\end{array}$ & $\begin{array}{l}\text { Questions:1 } \\
\text { Picture:0 }\end{array}$ \\
\hline $\begin{array}{l}\text { David Ben- } \\
\text { Gurion }\end{array}$ & $\begin{array}{l}\text { Sentences in } \\
\text { main text:0 } \\
\text { Index pgs.:0 } \\
\text { Review } \\
\text { Questions:0 } \\
\text { Picture:0 }\end{array}$ & $\begin{array}{l}\text { Sentences in } \\
\text { main text:9 } \\
\text { Index pgs.:3 } \\
\text { Review } \\
\text { Questions:2 } \\
\text { Picture: } 1\end{array}$ & $\begin{array}{l}\text { Sentences in } \\
\text { main text:0 } \\
\text { Index pgs.:0 } \\
\text { Review } \\
\text { Questions:0 } \\
\text { Picture:0 }\end{array}$ & $\begin{array}{l}\text { Sentences in } \\
\text { main text:9 } \\
\text { Index pgs.:3 } \\
\text { Review } \\
\text { Questions:2 } \\
\text { Picture:1 }\end{array}$ & $\begin{array}{l}\text { Sentences in } \\
\text { main text:0 } \\
\text { Index pgs.:0 } \\
\text { Review } \\
\text { Questions:0 } \\
\text { Picture:0 }\end{array}$ & $\begin{array}{l}\text { Sentences in } \\
\text { main text:5 } \\
\text { Index pgs.:2 } \\
\text { Review } \\
\text { Questions:1 } \\
\text { Picture:0 }\end{array}$ & $\begin{array}{l}\text { Sentences in } \\
\text { main text:0 } \\
\text { Index pgs.:0 } \\
\text { Review } \\
\text { Questions:0 } \\
\text { Picture:0 }\end{array}$ & $\begin{array}{l}\text { Sentences in } \\
\text { main text:5 } \\
\text { Index pgs.:2 } \\
\text { Review } \\
\text { Questions:1 } \\
\text { Picture:0 }\end{array}$ \\
\hline Golda Meir & $\begin{array}{l}\text { Sentences in } \\
\text { main text:0 } \\
\text { Index pgs.:0 } \\
\text { Review } \\
\text { Questions:0 } \\
\text { Picture: } 1\end{array}$ & $\begin{array}{l}\text { Sentences in } \\
\text { main text:3 } \\
\text { Index pgs.:2 } \\
\text { Review } \\
\text { Questions:1 } \\
\text { Picture:1 }\end{array}$ & $\begin{array}{l}\text { Sentences in } \\
\text { main text:1 } \\
\text { Index pgs.:0 } \\
\text { Review } \\
\text { Questions:0 } \\
\text { Picture:1 }\end{array}$ & $\begin{array}{l}\text { Sentences in } \\
\text { main text:4 } \\
\text { Index pgs.:2 } \\
\text { Review } \\
\text { Questions:1 } \\
\text { Picture:3 }\end{array}$ & $\begin{array}{l}\text { Sentences in } \\
\text { main text:0 } \\
\text { Index pgs.:0 } \\
\text { Review } \\
\text { Questions:0 } \\
\text { Picture:0 }\end{array}$ & $\begin{array}{l}\text { Sentences in } \\
\text { main text:1 } \\
\text { Index pgs.:1 } \\
\text { Review } \\
\text { Questions:2 } \\
\text { Picture:1 }\end{array}$ & $\begin{array}{l}\text { Sentences in } \\
\text { main text:0 } \\
\text { Index pgs.:0 } \\
\text { Review } \\
\text { Questions:0 } \\
\text { Picture:0 }\end{array}$ & $\begin{array}{l}\text { Sentences in } \\
\text { main text:1 } \\
\text { Index pgs.:1 } \\
\text { Review } \\
\text { Questions:2 } \\
\text { Picture:1 }\end{array}$ \\
\hline $\begin{array}{l}\text { Menachem } \\
\text { Begin }\end{array}$ & $\begin{array}{l}\text { Sentences in } \\
\text { main text:3 } \\
\text { Index pgs.:1 } \\
\text { Review } \\
\text { Questions:1 } \\
\text { Picture:1 }\end{array}$ & $\begin{array}{l}\text { Sentences in } \\
\text { main text:7 } \\
\text { Index pgs.:3 } \\
\text { Review } \\
\text { Questions:1 } \\
\text { Picture:1 }\end{array}$ & $\begin{array}{l}\begin{array}{l}\text { Sentences in } \\
\text { main text:7 }\end{array} \\
\text { Index pgs.:1 } \\
\text { Review } \\
\text { Questions:3 } \\
\text { Picture:1 }\end{array}$ & $\begin{array}{l}\text { Sentences in } \\
\text { main text:17 } \\
\text { Index pgs.:5 } \\
\text { Review } \\
\text { Questions:5 } \\
\text { Picture:3 }\end{array}$ & $\begin{array}{l}\text { Sentences in } \\
\text { main text:3 } \\
\text { Index pgs.:1 } \\
\text { Review } \\
\text { Questions:0 } \\
\text { Picture:2 }\end{array}$ & $\begin{array}{l}\text { Sentences in } \\
\text { main text:6 } \\
\text { Index pgs.:1 } \\
\text { Review } \\
\text { Questions:1 } \\
\text { Picture:1 }\end{array}$ & $\begin{array}{l}\text { Sentences in } \\
\text { main text:3 } \\
\text { Index pgs.:1 } \\
\text { Review } \\
\text { Questions:0 } \\
\text { Picture:1 }\end{array}$ & $\begin{array}{l}\text { Sentences in } \\
\text { main text:12 } \\
\text { Index pgs.:3 } \\
\text { Review } \\
\text { Questions:1 } \\
\text { Picture:4 }\end{array}$ \\
\hline Anwar Sadat & $\begin{array}{l}\text { Sentences in } \\
\text { main text: } 6\end{array}$ & $\begin{array}{l}\text { Sentences in } \\
\text { main text: } 16\end{array}$ & $\begin{array}{l}\text { Sentences in } \\
\text { main text: } 7\end{array}$ & $\begin{array}{l}\text { Sentences in } \\
\text { main text:29 }\end{array}$ & $\begin{array}{l}\text { Sentences in } \\
\text { main text: } 3\end{array}$ & $\begin{array}{l}\text { Sentences in } \\
\text { main text: } 6\end{array}$ & $\begin{array}{l}\text { Sentences in } \\
\text { main text: } 3\end{array}$ & $\begin{array}{l}\text { Sentences in } \\
\text { main text:12 }\end{array}$ \\
\hline
\end{tabular}




\begin{tabular}{|c|c|c|c|c|c|c|c|c|}
\hline & $\begin{array}{l}\text { Index pgs.:2 } \\
\text { Review } \\
\text { Questions:1 } \\
\text { Picture:1 }\end{array}$ & $\begin{array}{l}\text { Index pgs.:3 } \\
\text { Review } \\
\text { Questions:3 } \\
\text { Picture:1 }\end{array}$ & $\begin{array}{l}\text { Index pgs.:1 } \\
\text { Review } \\
\text { Questions:3 } \\
\text { Picture:1 }\end{array}$ & $\begin{array}{l}\text { Index pgs.:6 } \\
\text { Review } \\
\text { Questions:7 } \\
\text { Picture:3 }\end{array}$ & $\begin{array}{l}\text { Index pgs.:1 } \\
\text { Review } \\
\text { Questions:0 } \\
\text { Picture:2 }\end{array}$ & $\begin{array}{l}\text { Index pgs.:1 } \\
\text { Review } \\
\text { Questions:1 } \\
\text { Picture:1 }\end{array}$ & $\begin{array}{l}\text { Index pgs.:1 } \\
\text { Review } \\
\text { Questions:0 } \\
\text { Picture:1 }\end{array}$ & $\begin{array}{l}\text { Index pgs.:3 } \\
\text { Review } \\
\text { Questions:1 } \\
\text { Picture:4 }\end{array}$ \\
\hline Yasir Arafat & $\begin{array}{l}\text { Sentences in } \\
\text { main text:3 } \\
\text { Index pgs.:1 } \\
\text { Review } \\
\text { Questions:0 } \\
\text { Picture:1 }\end{array}$ & $\begin{array}{l}\text { Sentences in } \\
\text { main text:4 } \\
\text { Index pgs.:1 } \\
\text { Review } \\
\text { Questions:1 } \\
\text { Picture:0 }\end{array}$ & $\begin{array}{l}\text { Sentences in } \\
\text { main text:7 } \\
\text { Index pgs.:1 } \\
\text { Review } \\
\text { Questions:3 } \\
\text { Picture:2 }\end{array}$ & $\begin{array}{l}\text { Sentences in } \\
\text { main text:14 } \\
\text { Index pgs.:3 } \\
\text { Review } \\
\text { Questions:4 } \\
\text { Picture:2 }\end{array}$ & $\begin{array}{l}\text { Sentences in } \\
\text { main text:0 } \\
\text { Index pgs.:0 } \\
\text { Review } \\
\text { Questions:0 } \\
\text { Picture:0 }\end{array}$ & $\begin{array}{l}\text { Sentences in } \\
\text { main text:4 } \\
\text { Index pgs.:1 } \\
\text { Review } \\
\text { Questions:1 } \\
\text { Picture:1 }\end{array}$ & $\begin{array}{l}\text { Sentences in } \\
\text { main text:2 } \\
\text { Index pgs.:1 } \\
\text { Review } \\
\text { Questions:0 } \\
\text { Picture:0 }\end{array}$ & $\begin{array}{l}\begin{array}{l}\text { Sentences in } \\
\text { main text:6 }\end{array} \\
\text { Index pgs.:2 } \\
\text { Review } \\
\text { Questions:1 } \\
\text { Picture:1 }\end{array}$ \\
\hline $\begin{array}{l}\text { Gamal Abdal } \\
\text { Nasser }\end{array}$ & $\begin{array}{l}\text { Sentences in } \\
\text { main text:3 } \\
\text { Index pgs.:1 } \\
\text { Review } \\
\text { Questions:1 } \\
\text { Picture:0 }\end{array}$ & $\begin{array}{l}\text { Sentences in } \\
\text { main text:4 } \\
\text { Index pgs.:1 } \\
\text { Review } \\
\text { Questions:0 } \\
\text { Picture:0 }\end{array}$ & $\begin{array}{l}\text { Sentences in } \\
\text { main text:0 } \\
\text { Index pgs.:0 } \\
\text { Review } \\
\text { Questions:0 } \\
\text { Picture:0 }\end{array}$ & $\begin{array}{l}\text { Sentences in } \\
\text { main text:7 } \\
\text { Index pgs.:2 } \\
\text { Review } \\
\text { Questions:1 } \\
\text { Picture:0 }\end{array}$ & $\begin{array}{l}\text { Sentences in } \\
\text { main text:4 } \\
\text { Index pgs.:1 } \\
\text { Review } \\
\text { Questions:0 } \\
\text { Picture:0 }\end{array}$ & $\begin{array}{l}\text { Sentences in } \\
\text { main text:1 } \\
\text { Index pgs.:1 } \\
\text { Review } \\
\text { Questions:0 } \\
\text { Picture:0 }\end{array}$ & $\begin{array}{l}\text { Sentences in } \\
\text { main text:1 } \\
\text { Index pgs.:1 } \\
\text { Review } \\
\text { Questions:0 } \\
\text { Picture:0 }\end{array}$ & $\begin{array}{l}\begin{array}{l}\text { Sentences in } \\
\text { main text:6 }\end{array} \\
\text { Index pgs.:3 } \\
\text { Review } \\
\text { Questions:0 } \\
\text { Picture:0 }\end{array}$ \\
\hline Yitzhak Rabin & $\begin{array}{l}\text { Sentences in } \\
\text { main text:2 } \\
\text { Index pgs.:1 }\end{array}$ & $\begin{array}{l}\text { Sentences in } \\
\text { main text:4 } \\
\text { Index pgs.:1 }\end{array}$ & $\begin{array}{l}\text { Sentences in } \\
\text { main text: } 7 \\
\text { Index pgs.: } 1\end{array}$ & $\begin{array}{l}\text { Sentences in } \\
\text { main text:13 } \\
\text { Index pgs.:3 }\end{array}$ & $\begin{array}{l}\text { Sentences in } \\
\text { main text:0 } \\
\text { Index pgs.:0 }\end{array}$ & $\begin{array}{l}\text { Sentences in } \\
\text { main text:4 } \\
\text { Index pgs.: } 1\end{array}$ & $\begin{array}{l}\text { Sentences in } \\
\text { main text:2 } \\
\text { Index pgs.:1 }\end{array}$ & $\begin{array}{l}\text { Sentences in } \\
\text { main text:6 } \\
\text { Index pgs.:2 }\end{array}$ \\
\hline
\end{tabular}




\begin{tabular}{|c|c|c|c|c|c|c|c|c|}
\hline & $\begin{array}{l}\text { Review } \\
\text { Questions:0 } \\
\text { Picture:1 }\end{array}$ & $\begin{array}{l}\text { Review } \\
\text { Questions:1 } \\
\text { Picture:0 }\end{array}$ & $\begin{array}{l}\text { Review } \\
\text { Questions:3 } \\
\text { Picture:2 }\end{array}$ & $\begin{array}{l}\text { Review } \\
\text { Questions:4 } \\
\text { Picture:3 }\end{array}$ & $\begin{array}{l}\text { Review } \\
\text { Questions:0 } \\
\text { Picture:1 }\end{array}$ & $\begin{array}{l}\text { Review } \\
\text { Questions:1 } \\
\text { Picture:1 }\end{array}$ & $\begin{array}{l}\text { Review } \\
\text { Questions:0 } \\
\text { Picture:0 }\end{array}$ & $\begin{array}{l}\text { Review } \\
\text { Questions:1 } \\
\text { Picture:2 }\end{array}$ \\
\hline $\begin{array}{l}\text { Term: } \\
\text { "Arab (s)" }\end{array}$ & $\begin{array}{l}\text { Sentences in } \\
\text { main text:15 } \\
\text { Index pgs.:1 } \\
\text { Review } \\
\text { Questions:0 } \\
\text { Picture:1 }\end{array}$ & $\begin{array}{l}\text { Sentences in } \\
\text { main text:46 } \\
\text { Index pgs.:0 } \\
\text { Review } \\
\text { Questions:1 } \\
\text { Picture:0 }\end{array}$ & $\begin{array}{l}\text { Sentences in } \\
\text { main text:15 } \\
\text { Index pgs.:0 } \\
\text { Review } \\
\text { Questions:0 } \\
\text { Picture:0 }\end{array}$ & $\begin{array}{l}\text { Sentences in } \\
\text { main text:76 } \\
\text { Index pgs.:1 } \\
\text { Review } \\
\text { Questions:1 } \\
\text { Picture:1 }\end{array}$ & $\begin{array}{l}\text { Sentences in } \\
\text { main text:5 } \\
\text { Index pgs.:0 } \\
\text { Review } \\
\text { Questions:1 } \\
\text { Picture:0 }\end{array}$ & $\begin{array}{l}\text { Sentences in } \\
\text { main text:16 } \\
\text { Index pgs.:0 } \\
\text { Review } \\
\text { Questions:2 } \\
\text { Picture:0 }\end{array}$ & $\begin{array}{l}\text { Sentences in } \\
\text { main text:13 } \\
\text { Index pgs.:0 } \\
\text { Review } \\
\text { Questions:0 } \\
\text { Picture:0 }\end{array}$ & $\begin{array}{l}\text { Sentences in } \\
\text { main text:34 } \\
\text { Index pgs.:0 } \\
\text { Review } \\
\text { Questions:3 } \\
\text { Picture:0 }\end{array}$ \\
\hline $\begin{array}{l}\text { Term: } \\
\text { "Israel" } \\
\text { and/or } \\
\text { "Israeli" }\end{array}$ & $\begin{array}{l}\text { Sentences in } \\
\text { main text:52 } \\
\text { Index pgs.:8 } \\
\text { Review } \\
\text { Questions:0 } \\
\text { Picture: } 1\end{array}$ & $\begin{array}{l}\text { Sentences in } \\
\text { main text:59 } \\
\text { Index pgs.:9 } \\
\text { Review } \\
\text { Questions:2 } \\
\text { Picture:1 }\end{array}$ & $\begin{array}{l}\text { Sentences in } \\
\text { main text:49 } \\
\text { Index pgs.:4 } \\
\text { Review } \\
\text { Questions:5 } \\
\text { Picture:1 }\end{array}$ & $\begin{array}{l}\begin{array}{l}\text { Sentences in } \\
\text { main } \\
\text { text:151 }\end{array} \\
\text { Index } \\
\text { pgs.:21 } \\
\text { Review } \\
\text { Questions:7 } \\
\text { Picture:3 }\end{array}$ & $\begin{array}{l}\text { Sentences in } \\
\text { main text:30 } \\
\text { Index pgs.:3 } \\
\text { Review } \\
\text { Questions:0 } \\
\text { Picture: } 1\end{array}$ & $\begin{array}{l}\text { Sentences in } \\
\text { main text:28 } \\
\text { Index pgs.:6 } \\
\text { Review } \\
\text { Questions:0 } \\
\text { Picture:0 }\end{array}$ & $\begin{array}{l}\text { Sentences in } \\
\text { main text:39 } \\
\text { Index pgs.:5 } \\
\text { Review } \\
\text { Questions:1 } \\
\text { Picture:1 }\end{array}$ & $\begin{array}{l}\text { Sentences in } \\
\text { main text:97 } \\
\text { Index } \\
\text { pgs.:14 } \\
\text { Review } \\
\text { Questions:1 } \\
\text { Picture:2 }\end{array}$ \\
\hline $\begin{array}{l}\text { Term: } \\
\text { "Jews" }\end{array}$ & $\begin{array}{l}\text { Sentences in } \\
\text { main text:0 }\end{array}$ & $\begin{array}{l}\text { Sentences in } \\
\text { main text: } 15\end{array}$ & $\begin{array}{l}\text { Sentences in } \\
\text { main text: } 8\end{array}$ & $\begin{array}{l}\text { Sentences in } \\
\text { main text:23 }\end{array}$ & $\begin{array}{l}\text { Sentences in } \\
\text { main text: } 10\end{array}$ & $\begin{array}{l}\text { Sentences in } \\
\text { main text: } 20\end{array}$ & $\begin{array}{l}\text { Sentences in } \\
\text { main text: } 8\end{array}$ & $\begin{array}{l}\text { Sentences in } \\
\text { main text:38 }\end{array}$ \\
\hline
\end{tabular}




\begin{tabular}{|c|c|c|c|c|c|c|c|c|}
\hline $\begin{array}{l}\text { and/or } \\
\text { "Jewish" }\end{array}$ & $\begin{array}{l}\text { Index pgs.:4 } \\
\text { Review } \\
\text { Questions:0 } \\
\text { Picture:0 }\end{array}$ & $\begin{array}{l}\text { Index pgs.:7 } \\
\text { Review } \\
\text { Questions:0 } \\
\text { Picture:0 }\end{array}$ & $\begin{array}{l}\text { Index pgs.:0 } \\
\text { Review } \\
\text { Questions:0 } \\
\text { Picture:0 }\end{array}$ & $\begin{array}{l}\text { Index } \\
\text { pgs.:21 } \\
\text { Review } \\
\text { Questions:0 } \\
\text { Picture:0 }\end{array}$ & $\begin{array}{l}\text { Index pgs.:11 } \\
\text { Review } \\
\text { Questions:0 } \\
\text { Picture:0 }\end{array}$ & $\begin{array}{l}\text { Index pgs.:9 } \\
\text { Review } \\
\text { Questions:2 } \\
\text { Picture:0 }\end{array}$ & $\begin{array}{l}\text { Index pgs.:7 } \\
\text { Review } \\
\text { Questions:0 } \\
\text { Picture:0 }\end{array}$ & $\begin{array}{l}\text { Index } \\
\text { pgs.:27 } \\
\text { Review } \\
\text { Questions:2 } \\
\text { Picture:0 }\end{array}$ \\
\hline $\begin{array}{l}\text { Term: } \\
\text { "Palestine" }\end{array}$ & $\begin{array}{l}\text { Sentences in } \\
\text { main text:2 } \\
\text { Index pgs.:0 } \\
\text { Review } \\
\text { Questions:0 } \\
\text { Picture:0 }\end{array}$ & $\begin{array}{l}\text { Sentences in } \\
\text { main text:14 } \\
\text { Index pgs.:0 } \\
\text { Review } \\
\text { Questions:1 } \\
\text { Picture:0 }\end{array}$ & $\begin{array}{l}\text { Sentences in } \\
\text { main text:11 } \\
\text { Index pgs.:0 } \\
\text { Review } \\
\text { Questions:0 } \\
\text { Picture:0 }\end{array}$ & $\begin{array}{l}\begin{array}{l}\text { Sentences in } \\
\text { main text:27 }\end{array} \\
\text { Index pgs.:0 } \\
\text { Review } \\
\text { Questions:1 } \\
\text { Picture:0 }\end{array}$ & $\begin{array}{l}\text { Sentences in } \\
\text { main text:3 } \\
\text { Index pgs.:0 } \\
\text { Review } \\
\text { Questions:0 } \\
\text { Picture:0 }\end{array}$ & $\begin{array}{l}\text { Sentences in } \\
\text { main text:14 } \\
\text { Index pgs.:2 } \\
\text { Review } \\
\text { Questions:2 } \\
\text { Picture:0 }\end{array}$ & $\begin{array}{l}\text { Sentences in } \\
\text { main text:7 } \\
\text { Index pgs.:2 } \\
\text { Review } \\
\text { Questions:0 } \\
\text { Picture:0 }\end{array}$ & $\begin{array}{l}\begin{array}{l}\text { Sentences in } \\
\text { main text:24 }\end{array} \\
\text { Index pgs.:4 } \\
\text { Review } \\
\text { Questions:2 } \\
\text { Picture:0 }\end{array}$ \\
\hline $\begin{array}{l}\text { Term: } \\
\text { "Palestinian", }\end{array}$ & $\begin{array}{l}\text { Sentences in } \\
\text { main text:14 } \\
\text { Index pgs.:0 } \\
\text { Review } \\
\text { Questions:0 } \\
\text { Picture:1 }\end{array}$ & $\begin{array}{l}\text { Sentences in } \\
\text { main text:1 } \\
\text { Index pgs.:1 } \\
\text { Review } \\
\text { Questions:0 } \\
\text { Picture:0 }\end{array}$ & $\begin{array}{l}\text { Sentences in } \\
\text { main text:15 } \\
\text { Index pgs.:0 } \\
\text { Review } \\
\text { Questions:1 } \\
\text { Picture:0 }\end{array}$ & $\begin{array}{l}\text { Sentences in } \\
\text { main text:45 } \\
\text { Index pgs.:1 } \\
\text { Review } \\
\text { Questions:1 } \\
\text { Picture:1 }\end{array}$ & $\begin{array}{l}\text { Sentences in } \\
\text { main text:7 } \\
\text { Index pgs.:2 } \\
\text { Review } \\
\text { Questions:0 } \\
\text { Picture:0 }\end{array}$ & $\begin{array}{l}\text { Sentences in } \\
\text { main text:4 } \\
\text { Index pgs.:0 } \\
\text { Review } \\
\text { Questions:1 } \\
\text { Picture:0 }\end{array}$ & $\begin{array}{l}\text { Sentences in } \\
\text { main text:8 } \\
\text { Index pgs.:3 } \\
\text { Review } \\
\text { Questions:0 } \\
\text { Picture:1 }\end{array}$ & $\begin{array}{l}\begin{array}{l}\text { Sentences in } \\
\text { main text:19 }\end{array} \\
\text { Index pgs.:5 } \\
\text { Review } \\
\text { Questions:1 } \\
\text { Picture:1 }\end{array}$ \\
\hline
\end{tabular}


Mandate System/Balfour Declaration/1948 War/Establishment of Israel:

\begin{tabular}{|c|c|c|c|c|c|c|c|}
\hline Publisher & $1950 \mathrm{~s}$ & $1960 \mathrm{~s}$ & $1970 \mathrm{~s}$ & $1980 \mathrm{~s}$ & $1990 \mathrm{~s}$ & $2000 \mathrm{~s}$ & Totals \\
\hline HM & $\mathrm{X}$ & $\mathrm{X}$ & $2(\mathrm{P})$ & $1(\mathrm{P})$ & $\mathrm{X}$ & $1(\mathrm{~A})$ & $\mathbf{4}$ \\
\hline HOLT & $2(\mathrm{~N})$ & $3(\mathrm{~N})$ & $3(\mathrm{~N})$ & $2(\mathrm{~N})$ & $3(\mathrm{P})$ & $3(\mathrm{P})$ & $\mathbf{1 6}$ \\
\hline PH & $3(\mathrm{P})$ & $2(\mathrm{~A})$ & $1(\mathrm{~A})$ & $3(\mathrm{~A})$ & $2(\mathrm{~N})$ & $2(\mathrm{~N})$ & $\mathbf{1 3}$ \\
\hline
\end{tabular}

1956 Suez War:

\begin{tabular}{|c|c|c|c|c|c|c|c|}
\hline Publisher & $1950 \mathrm{~s}$ & $1960 \mathrm{~s}$ & $1970 \mathrm{~s}$ & $1980 \mathrm{~s}$ & $1990 \mathrm{~s}$ & $2000 \mathrm{~s}$ & Totals \\
\hline HM & $\mathrm{X}$ & $1(\mathrm{P})$ & $1(\mathrm{~A})$ & $2(\mathrm{P})$ & $3(\mathrm{P})$ & $2(\mathrm{~N})$ & $\mathbf{8}$ \\
\hline HOLT & $\mathrm{X}$ & $3(\mathrm{~A})$ & $2(\mathrm{~A})$ & $3(\mathrm{~A})$ & $2(\mathrm{~N})$ & $3(\mathrm{~N})$ & $\mathbf{1 3}$ \\
\hline PH & $1(\mathrm{P})$ & $2(\mathrm{~A})$ & $3(\mathrm{~A})$ & $\mathrm{X}$ & $\mathrm{X}$ & $1(\mathrm{~A})$ & $\mathbf{7}$ \\
\hline
\end{tabular}


1967 Six Day War:

\begin{tabular}{|c|c|c|c|c|c|c|c|}
\hline Publisher & $1950 \mathrm{~s}$ & $1960 \mathrm{~s}$ & $1970 \mathrm{~s}$ & $1980 \mathrm{~s}$ & $1990 \mathrm{~s}$ & $2000 \mathrm{~s}$ & Totals \\
\hline HM & $\mathrm{X}$ & $\mathrm{X}$ & $1(\mathrm{~N})$ & $1(\mathrm{~N})$ & $\mathrm{X}$ & $\mathrm{X}$ & $\mathbf{2}$ \\
\hline HOLT & $\mathrm{X}$ & $\mathrm{X}$ & $2(\mathrm{~A})$ & $2(\mathrm{~A})$ & $1(\mathrm{~A})$ & $\mathrm{X}$ & $\mathbf{5}$ \\
\hline PH & $\mathrm{X}$ & $\mathrm{X}$ & $3(\mathrm{~N})$ & $3(\mathrm{~N})$ & $\mathrm{X}$ & $\mathrm{X}$ & $\mathbf{6}$ \\
\hline
\end{tabular}

1973 Yom Kippur War:

\begin{tabular}{|c|c|c|c|c|c|c|c|}
\hline Publisher & $1950 \mathrm{~s}$ & $1960 \mathrm{~s}$ & $1970 \mathrm{~s}$ & $1980 \mathrm{~s}$ & $1990 \mathrm{~s}$ & $2000 \mathrm{~s}$ & Totals \\
\hline HM & $\mathrm{X}$ & $\mathrm{X}$ & $2(\mathrm{P})$ & $1(\mathrm{~N})$ & $1(\mathrm{~A})$ & $3(\mathrm{P})$ & $\mathbf{7}$ \\
\hline HOLT & $\mathrm{X}$ & $\mathrm{X}$ & $3(\mathrm{P})$ & $3(\mathrm{P})$ & $3(\mathrm{P})$ & $1(\mathrm{~N})$ & $\mathbf{1 0}$ \\
\hline PH & $\mathrm{X}$ & $\mathrm{X}$ & $1(\mathrm{~N})$ & $2(\mathrm{~A})$ & $2(\mathrm{~N})$ & $2(\mathrm{~A})$ & $\mathbf{7}$ \\
\hline
\end{tabular}


1979 Camp David:

\begin{tabular}{|c|c|c|c|c|c|c|c|}
\hline Publisher & $1950 \mathrm{~s}$ & $1960 \mathrm{~s}$ & $1970 \mathrm{~s}$ & $1980 \mathrm{~s}$ & $1990 \mathrm{~s}$ & $2000 \mathrm{~s}$ & Totals \\
\hline HM & $\mathrm{X}$ & $\mathrm{X}$ & $\mathrm{X}$ & $1(\mathrm{~N})$ & $2(\mathrm{P})$ & $2(\mathrm{~N})$ & $\mathbf{5}$ \\
\hline HOLT & $\mathrm{X}$ & $\mathrm{X}$ & $\mathrm{X}$ & $2(\mathrm{P})$ & $1(\mathrm{~N})$ & $1(\mathrm{~N})$ & $\mathbf{4}$ \\
\hline PH & $\mathrm{X}$ & $\mathrm{X}$ & $\mathrm{X}$ & $3(\mathrm{~N})$ & $3(\mathrm{~N})$ & $3(\mathrm{~N})$ & $\mathbf{9}$ \\
\hline
\end{tabular}

1980s Conflict in Lebanon:

\begin{tabular}{|c|c|c|c|c|c|c|c|}
\hline Publisher & $1950 \mathrm{~s}$ & $1960 \mathrm{~s}$ & $1970 \mathrm{~s}$ & $1980 \mathrm{~s}$ & $1990 \mathrm{~s}$ & $2000 \mathrm{~s}$ & Totals \\
\hline HM & $\mathrm{X}$ & $\mathrm{X}$ & $\mathrm{X}$ & $\mathrm{X}$ & $2(\mathrm{~A})$ & $\mathrm{X}$ & $\mathbf{2}$ \\
\hline HOLT & $\mathrm{X}$ & $\mathrm{X}$ & $\mathrm{X}$ & $1(\mathrm{~A})$ & $\mathrm{X}$ & $\mathrm{X}$ & $\mathbf{1}$ \\
\hline PH & $\mathrm{X}$ & $\mathrm{X}$ & $\mathrm{X}$ & $2(\mathrm{P})$ & $1(\mathrm{P})$ & $1(\mathrm{~N})$ & $\mathbf{4}$ \\
\hline
\end{tabular}


1990s Peace Negotiations:

\begin{tabular}{|c|c|c|c|c|c|c|c|}
\hline Publisher & $1950 \mathrm{~s}$ & $1960 \mathrm{~s}$ & $1970 \mathrm{~s}$ & $1980 \mathrm{~s}$ & $1990 \mathrm{~s}$ & $2000 \mathrm{~s}$ & Totals \\
\hline HM & $\mathrm{X}$ & $\mathrm{X}$ & $\mathrm{X}$ & $\mathrm{X}$ & $2(\mathrm{~N})$ & $\mathrm{X}$ & $\mathbf{2}$ \\
\hline HOLT & $\mathrm{X}$ & $\mathrm{X}$ & $\mathrm{X}$ & $\mathrm{X}$ & $1(\mathrm{~A})$ & $1(\mathrm{~A})$ & $\mathbf{2}$ \\
\hline PH & $\mathrm{X}$ & $\mathrm{X}$ & $\mathrm{X}$ & $\mathrm{X}$ & $3(\mathrm{~N})$ & $2(\mathrm{~N})$ & $\mathbf{5}$ \\
\hline
\end{tabular}

\section{Post 9/11:}

\begin{tabular}{|c|c|c|c|c|c|c|c|}
\hline Publisher & $1950 \mathrm{~s}$ & $1960 \mathrm{~s}$ & $1970 \mathrm{~s}$ & $1980 \mathrm{~s}$ & $1990 \mathrm{~s}$ & $2000 \mathrm{~s}$ & Totals \\
\hline HM & $\mathrm{X}$ & $\mathrm{X}$ & $\mathrm{X}$ & $\mathrm{X}$ & $\mathrm{X}$ & $3(\mathrm{~N})$ & $\mathbf{3}$ \\
\hline HOLT & $\mathrm{X}$ & $\mathrm{X}$ & $\mathrm{X}$ & $\mathrm{X}$ & $\mathrm{X}$ & $\mathrm{X}$ & $\mathrm{X}$ \\
\hline PH & $\mathrm{X}$ & $\mathrm{X}$ & $\mathrm{X}$ & $\mathrm{X}$ & $\mathrm{X}$ & $2(\mathrm{~A})$ & $\mathbf{2}$ \\
\hline
\end{tabular}


